\title{
Revista Argelina
}

Revista semestral de Estudios Argelinos

Primavera 2016

Número 2

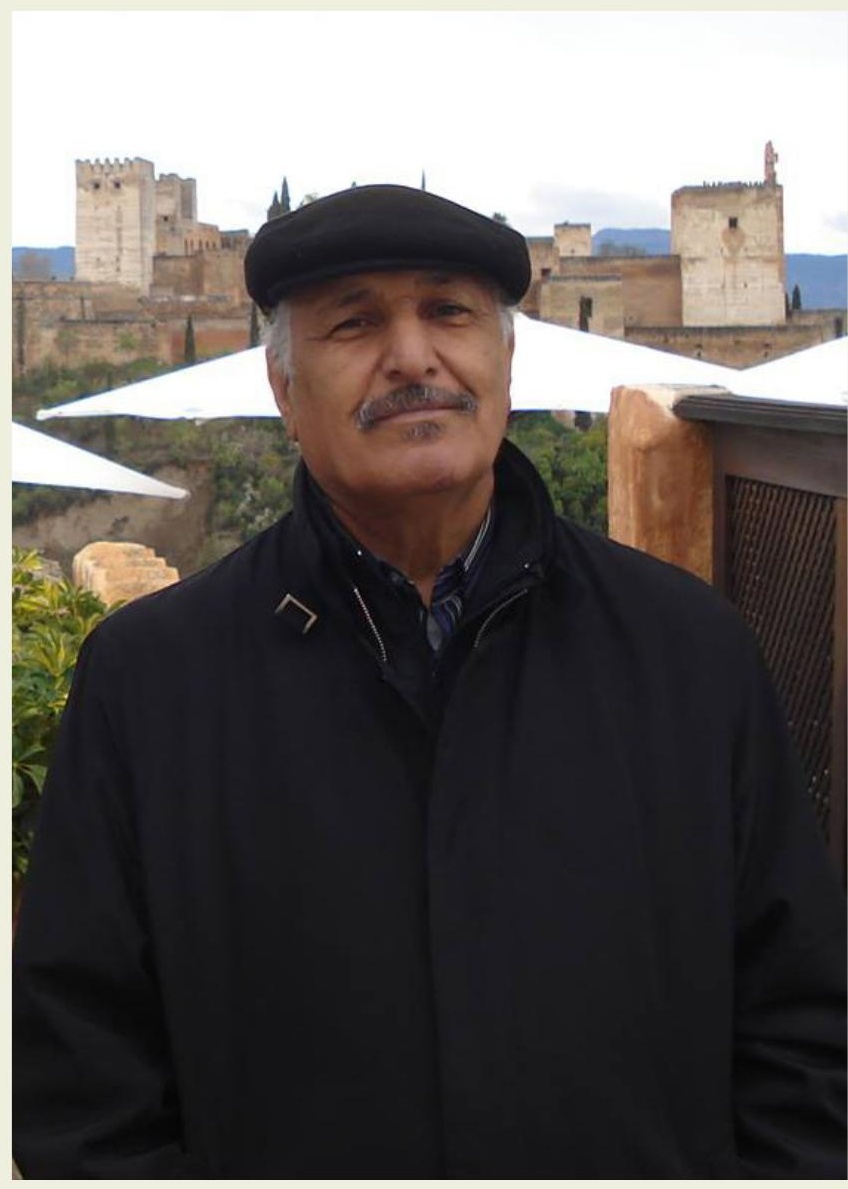

Universitat d'Alacant
Universidad de Alicante 
Número 2 • Primavera 2016

\section{Revista Argelina}

Revista semestral de Estudios Argelinos 


\section{Revista Argelina}

Revista semestral de Estudios Argelinos

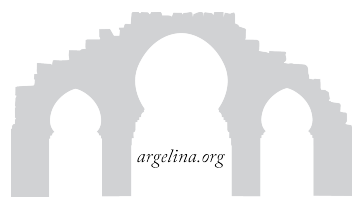

Revista Argelina. Revista semestral de Estudios Argelinos es una publicación electrónica semestral editada por el Área de Estudios Árabes e Islámicos de la Universidad de Alicante que edita dos tomos anuales de investigación y reflexión en torno a las letras, cultura, historia y actualidad de Argelia. Una versión extendida de la revista se publica en papel por la Editorial Hispano-Árabe.

\section{Comité editorial:}

Directora: Naima Benaicha Ziani

Subdirector: Isaac Donoso

Secretario técnico: Didac Conesa

Exención de responsabilidad:

Las opiniones y datos contenidos en cada texto son de exclusiva responsabilidad de sus autores. Revista Argelina no comparte necesariamente las opiniones vertidas por los autores ni se hace responsable de los trabajos.

$$
\begin{gathered}
\text { Imprime: } \\
\text { Editorial Hispano-Árabe } \\
\text { http://www.editorial-hispanoarabe.com } \\
\hline \text { Calle de los Jazmines No } 17 \\
\text { Talamanca de Jarama } \\
28160 \text { Madrid } \\
\text { Tel. } 639707720 \\
\text { Correspondencia y redacción: }
\end{gathered}
$$

Área de Estudios Árabes e Islámicos de la Universidad de Alicante, Carretera de San Vicente del Raspeig, s/n, 03690 Alicante.

La revista esta disponible a texto completo en internet en la dirección siguiente: $\underline{\text { http://argelina.org }}$

Portada:

Fotografía del poeta Abdallah Hammadi frente a la Alhambra

(C) De los autores de los artículos originales.

(C) Revista Argelina, 2016 


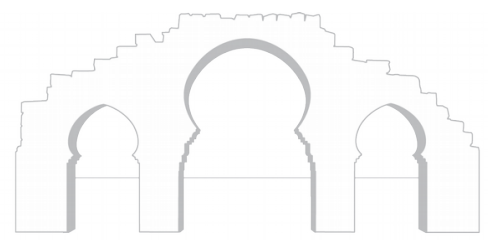

Revista Argelina • Número 2 • Primavera 2016

\section{ÍNDICE}

\section{Editorial}

Homenaje a Abdallah Hammadi

\section{Entrevista}

Entrevista con Abdallah Hammadi

\section{Artículos y notas}

IsAAC Donoso

Abdallah Hammadi: ética y estética neoandalusí....

Juan Martos Quesada

Abdallah Hammadi en España: poemas de juventud

AhMAd BAgAr

La construcción de la imagen en la poesía de Abdallah Hammadi

Mohammed Amine Shaika

Perspectiva crítica y filosófica en la dualidad de Al-barzaj wa al-sikkin del poeta Abdallah Hammadi ....................................................... 87

Kassem Masoud

El horizonte de expectativas en el diván Antiqu an al-hawà de Abdallah Hammadi. 
Rofia Boughanout

Modos de escritura: la influencia sufi en la titulación del diván Antiqu 'an alhawà de Abdallah Hammadi .............................................. 137

IsAac Donoso

Cuestiones epistemológicas de literatura hispanoargelina contemporánea ...... 171

\section{Biblioteca}

Abdallah Hammadi

Converso con el olvido (Poemas)

AbDallah Hammadi

El conservadurismo en la poesía árabe 


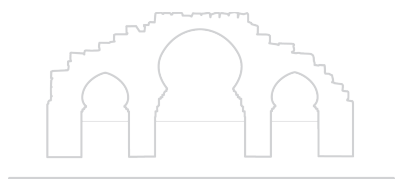

\section{Editorial}

La historia es el mejor testigo de que el intercambio de ideas siempre ha existido entre Argelia y España. Muchos de los investigadores y escritores argelinos de lengua española, como el caso de nuestro homenajeado Dr. Abdallah Hammadi, han comprendido que la lengua española es un puente ineludible para acercar posturas. Este número dos de Revista Argelina hemos querido aprovecharlo para recordar la calidad de los hispanistas argelinos y su valiosa aportación a la cultura hispánica. El poeta, escritor y crítico Dr. Abdallah Hammadi, es una personalidad literaria que merece un reconocimiento académico tanto en España como en todo el continente hispánico, con el deseo de que sea del agrado de nuestros lectores de lengua española.

N. B. Z. 



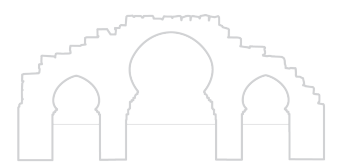

\section{Entrevista}





\section{ENTREVISTA CON ABDALLAH HAMMADI}

Entrevista electrónica realizada por Isaac Donoso y respondida por Abdallah Hammadi durante el mes de julio del año 2016. Se respeta la expresión y giros propios del autor como muestra de lengua española en Argelia.

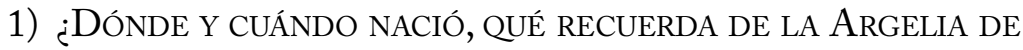
SU INFANCIA?

Nací el 10 de marzo 1947 en una aldea situada al norte de Constantina, casi a 27 kilómetros de la misma, que hoy día lleva el nombre del Héroe de la revolución argelina Zighoud Youcef, nativo de la misma aldea. Mi familia fueron agricultores en aquel pueblo, y nuestro árbol genealógico registrado para la $\mathrm{Ad}-$ ministración colonial francesa existe hasta hoy día.

En los años cincuenta del siglo pasado la colonización francesa confiscó nuestras tierras después de una persecución de muchos hombres de mi familia, considerados rebeldes, hasta el punto que ha obligado a mis padre a refugiarse en Túnez alrededor de los años de 1951. En Túnez nos instalamos en una aldea que se llama Krib Village, departamento de Beja, donde había muchos refugiados argelinos hasta el punto que aquella aldea fue repartida entre argelinos refugiados y tunecinos autóctonos (hablé de aquella convivencia en mi novela titulada Tafunasit editada por la Biblioteca Nacional de Argelia el ano 2004; el titulo Tafunasit es una palabra bereber que significa "la vaca"; en esta novela hablé por primera vez del fenómeno de los refugiados argelinos en la Literatura argelina moderna, y hablé también de mi emigración cultural en España).

En aquel pueblo de campesinos ocurrió mi juventud, y allí empecé mi primer contacto con la escuela primaria colonial antes de la independencia de Túnez, en los años de 1955. En 
aquel pueblo que se llama Krib Village... pueblo completamente campesino, que tiene una feria todos los martes (el zoco) fue donde aprendí mucho del juglar que recita muchas hazañas de la historia arabomusulmana y bereber, hasta llegar a cantar las hazañas de la Revolución Argelina que se proclamó el 1 de noviembre 1954 y duró hasta el 5 de julio 1962.

En aquel pueblo tenía una enseñanza bilingüe árabe y francés. En 1961 llegué a tener el certificado del Sixiéme, y no pude conseguir una beca para ir al Lyceo de la cuidad de Beja por ser argelino. Pero, donde menos esperaba, la revolución argelina conocida con su portavoz el FLN, me ofreció una beca para seguir mis estudios en el Lyceo de la cuidad de Beja en el norte de Túnez, y allí vi por primera vez en mi vida la ciudad, donde todo era diferente del pueblo. Ahí conocí al cine por ejemplo, o los partidos de fútbol, el teatro... En el mes de agosto de 1962 el Gobierno argelino se encargó de devolvernos a nuestra tierra tras la independencia de Argelia, y nos instalamos en la ciudad histórica y mítica de Constantina, que tiene más de tres mil años de existencia y su nombre se debe a su creador, el emperador romano Constantino el Grande.

2) ¿CUÁl FUe SU FORMACIÓn, SUS MAESTROS, CÓMO ERA EL AMBIENTE INTELECTUAL ARGELINO EN SU JUVENTUD?

Mis recuerdos de juventud son de Argelia independiente y de la Argelia del Presidente Houari Boumedien, que encarna la Argelia socialista. En Constantina volví otra vez a la vida de la cuidad, pero esta vez en una cuidad mas grande que la Beja tunecina. Y desde 1962 me llevó mi padre al Lyceo Franco-Musulmán, el único al este de Argelia que aseguraba una formación bilingüe, poco árabe y mucho francés. En el Lyceo tuve la oportunidad de conocer a un profesor libanés cristiano que me dio el curso de filosofía, y estaba casado con una española. Con su presencia con él, en los años 1966 empezó aquella dama tan 
elegante a enseñar la lengua española en aquel Lyceo por primera vez en su historia, y tuve la suerte de estudiar lengua española durante dos años, y de ahí vino mi primer contacto con la lengua española, y por primera vez aprendí el nombre de $\mathrm{Mi}$ guel de Cervantes, autor de la famosa novela Don Quijote de la Mancha, porque durante mi enseñanza francesa nos hizo aprender sólo su historia y su literatura, como si fuese que no existe en el mundo más que Francia.

Después del Lyceo se inauguró en Constantina en los años 1968 la Universidad de Constantina, con tres especialidades solamente: la Medicina en francés hasta hoy día, el Derecho en francés, y Literatura en francés y árabe. Elegí Literatura árabe y, en aquellos años de Nacionalismo y Socialismo, fuimos los literatos de la vanguardia, y tuve la suerte de tener como profesores a unos egipcios, como el gran profesor Ali Abdel-wahid Wafi y Omar Dasuki, y Nabih Hijab y Anas Daud, y otros grandes maestros de la literatura árabe antigua y moderna. Ahí, en aquellas aulas, empecé a escribir mis primeros poemas en los años 1971 y 1972 en un ambiente de lo que llamamos el Realismo social. Por eso me considera la crítica literaria argelina miembro de lo que llaman la "Generación de los años setenta». En mis años universitarios leí mucho los clásicos de la literatura árabe y llegué a aprender de memoria mas de cinco mil versos de poesía árabe clásica. $\mathrm{O}$ sea, tengo una formación clásica que se debe a la influencia directa de mis profesores, que estaban atados a los clásicos, menos mi profesor y poeta Anas Daud, gran especialista de los mitos en la poesía árabe moderna.

En cuanto al ambiente cultural de los setenta del siglo pasado en Argelia, era el Realismo social que domina la vida cultural donde había un grupo de jóvenes progresistas empezaron a escribir la poesía del verso libre y ocuparse de la vida social revolucionaria, según el nuevo proyecto de la sociedad del presidente Houwari Boumedien que se destaca en las tres revolucio- 
nes: revolución agraria, revolución industrial y revolución cultural. Así fue nuestra preocupación, además de ocuparnos con la liberación de los pueblos oprimidos en lo que llamamos el tercer mundo.

3) ¿Por qué FUe A EsTUdiar a EsPaña, DÓNDE Y QUÉ ESTUdió?

Al terminar mis estudios de Literatura en la Universidad de Constantina en 1972, como el mayor en la promoción, la Universidad nos eligió para enseñar en la Facultad de Letras como ayudante entre septiembre de 1972 hasta el 30 de junio de 1973. En aquel tiempo casi no existía ningún profesor argelino que diera clases en la Universidad de Constantina, porque mi generación fue la primera promoción de universitarios argelinos. Tras un año de enseñanza en la universidad, el gobierno de Boumedien decidió preparar nuevos profesores para el futuro de la universidad argelina, y decidió dar becas a casi todos los licenciados, y yo fui el primer estudiante argelino becario que llegó a la España de Franco en septiembre de 1973.

¿El por qué a España? Creo que fue por casualidad, o se debe a aquellas clases de español en el Lyceo Franco-Musulmán de Constantina, porque lo más corriente en Argelia en aquel tiempo era que los estudiantes argelinos siguieran sus estudios superiores en Francia, como era natural durante la colonización francesa. Por eso al llegar a la Embajada de Argelia en Madrid, se quedó estupefacto el agregado cultural, porque no había ningún estudiante argelino en España en aquel tiempo.

Mi experiencia cultural en España fue muy rica, porque al llegar a España tuvo lugar el golpe de Estado en Chile, y la muerte del gran poeta chileno Pablo Neruda, que acababa de publicar su último libro de poesía (El Nexonicidio), y de ahí nació mi gran interés por la poesía española contemporánea y moderna. Por eso terminé mi primera estancia en España con dos 
libros: Introducción a la poesía moderna española y Aproximación al poeta chileno Pablo Neruda.

Mis contactos con la poesía española se deben a mi residencia en el Colegio Mayor de Loyola en Moncloa, en Madrid, donde era el único estudiante árabe en aquella residencia, con una mayoría absoluta de estudiantes españoles de todas las regiones de España, por la cual llegué a conocer las diversidades lingüísticas y culturales de toda España. Además de las actividades culturales que ocurrían en el Colegio Loyola, asistí por primera vez al acto de la pieza teatral del poeta gitano Pepe Heredia Maya (Naquelamos Naquelar), que después de tantos años incluí en mi antología de la poesía andaluza moderna, que publiqué bajo el titulo al-Andalus entre el sueño y la realidad en 2011 en Argelia.

Allí conocí a grandes poetas como Antonio Hernández, Juan Goytisolo, y otros muchos que se encuentran en mi antología, y mi gran recuerdo fue mi visita a casa del gran poeta Vicente Aleixandre, donde fue la ocasión en la que traduje por primera vez algunos de sus poemas al árabe y fueron publicados en la famosa revista iraquí al-Aqlam, y tuve la suerte de recibir de la mano del poeta una dedicatoria de su libro de poesía Sombra del Paraíso.

En cuanto a la Universidad Complutense de Madrid, llegué a tener clases del gran arabista don Emilio García Gómez y también de Fernando de la Granja y del profesor y artista don Elías Terés. Y conocí a mis amigas María Jesús Viguera y María Jesús Rubiera, y a Serafín Fanjul, que tradujo algunos poemas míos, y al gran amigo y gran profesor Pedro Martínez Montávez, que me abrió la revista Almenara, donde he publicado algunos poemas.

Pero lo más destacado en aquellos años de la Universidad Complutense fueron los cursos intensivos de la literatura española contemporánea que daba el gran poeta y gran profesor de 
la crítica literaria modernista Carlos Bousoño, a los que asistí en sus clases durante dos años seguidos y aprendí su teoría innovadora ("el racionalismo verbal en la poesía moderna"), lo que me ha permitido ser uno de los más grandes teóricos de la poesía árabe moderna hoy día.

4) ¿Cuál fue el impacto intelectual Que España dejó en SU FORMACIÓN, Y CUÁLES FUERON SUS MAESTROS ESPAÑOLES?

En España viví la época de Franco, y recuerdo que España era como una isla alejada del mundo. Yo pasé casi un año entero sin encontrar una persona árabe para comunicarme con ella, pero reconozco que España en aquel tiempo era romántica, agradable para vivir, tranquila, y la vida era tan barata que con tres mil pesetas de beca se podía conseguir lo que quisieras. Me recuerdo también de las confrontaciones de los estudiantes con los "grises", como decían en aquel tiempo. Recuerdo también el famoso poema de Rafael Alberti contra Franco: "si los condenas a muerte serán los siete clavos en tu tumba...”.

En el año 1975 me fui a vivir a Granada para terminar mi tesina en Literatura andalusí. Allá conocí al-Andalus y al último reino musulmán de Granada. Pero a mí me gusta más Castilla, y me encanta leer el Poema del Mio Cid y sus encuentros con Al-Mutamid Rey de Sevilla, y con los Almorávides... y su amor por los poetas bandoleros de la época preislámica. Y de allí empecé a interesarme por los famosos romances de frontera, y por la poesía de Garcilaso de la Vega, poeta de la pluma y la espada como al-Mutanabbi.

No puedo negar mi amor por la cultura española y, sobre todo, por sus grandes, como Antonio Machado, García Lorca, Vicente Aleixandre, Luis Cernuda, Pedro Salinas, Miguel Hernández, César Vallejo... y Antonio Gala, etc. Gracias a ellos pude escribir mi famoso diván al-Barzaj wa-Siquin, galardona- 
do para la Fundación al-Babtain en 2002 como «Mejor Diván de la Poesía Árabe Contemporánea».

En Granada tenía como profesores al padre Darío Cabanelas, gran humanista, que me acogió con una fraternidad inolvidable, además de gran conocedor de la literatura andalusí. En cuanto a la vida cultural en Granada, tenía la suerte de conocer al poeta granadino, amigo de todos, Juan de Loxa, que me hizo conocer a todo el círculo literario de Andalucía en general y de Granada en especial, y tuve la suerte de asistir al primer homenaje dedicado a Lorca después de la muerte de Franco. En Granada conocí al gran poeta Rafael Guillén, que se encuentra en mi antología de la poesía andaluza.

Mi segunda estancia en España fue entre los años 1978 y 1980, donde acabé mi tesis doctoral con mi profesor Fernando de la Granja, al que le debo mucho, porque gracias a su generosa labor pude conseguir una beca del Instituto Hispano-Árabe de entonces y seguir en la Complutense. Pero por problemas de salud de mi profesor, don Fernando encargó a la profesora María Jesús Rubiera Mata para seguir conmigo, por ser especialista en la época nazarí de Granada.

Pero mis grandes recuerdos en aquella época fue mi amistad con el gran poeta iraquí Abdelwahab al-Bayati. Esta amistad me hizo ocuparme más de la poesía española, y llegamos a establecer muchas amistades con poetas españoles, ya que tuve que ser el intermediario entre al-Bayati y los poetas españoles. Tuve la suerte de que el día 16 de junio de 1980, fecha de la defensa de mi tesis doctoral, asistió al-Bayati, y el cantaor andaluz Carlos Cano, y mi amigo el poeta Julio Vélez...

5) ¿Por QUÉ DeCidió EsCRIBIR literatura EN LENGUA ESPANOLA?

Por todo lo que acabo de decir, y más todavía, por amor a España, tierra de entrecruce cultural y humano, tierra de mis antepa- 
sados bereberes y árabes, y por ser originario de los hammadíes, facción de los ziríes, reyes de Granada en la época de las Taifas. Me siento ligado a España, por eso amo su cultura, y su arte, y su poesía y su idioma, que tiene mucho de olor árabe, y en toda mi trayectoria cultural sigo buscando aquellos lazos que nos unen como pueblos civilizados que se han aprovechado de la tolerancia y la convivencia a lo largo de los siglos. El Magreb y España tienen una historia casi común, por eso siento los latidos poéticos de Antonio Machado y de García Lorca como si fuesen Nizar Kabbani o Mohammed Laid Califa.

También siento que la lengua española me ha liberado de la lengua colonial francesa, que nos ha atado a una época oscura de opresión e inigualdad, donde la ley colonial de los indígenas nos ha obligado, con fuerza, a creer en su cultura y su tradición y su modo de vida. Por eso quise escribir en español, y con una lengua hermana, donde Cervantes lleva tantos recuerdos de Argel, ciudad de tolerancia y de convivencia. Nada más hay que echar un vistazo a la literatura del cautiverio para confirmar lo que acabo de decir.

6) ¿CUÁl es la ESTÉTICA CON LA QUE TRATÓ DE ESCRIBIR CONVERSO CON EL OLVIDO, Y EL MENSAJE QUE QUERÍA TRANSMITIR?

En cuanto a mi libro de poesía/diván Converso con el olvido, es un canto a una tierra perdida, a una vida de magia y dulzura, a al-Andalus, tierra de arte y de poetas, donde fue el rey Mutamid mecenas de los poetas y amante del cante hondo y de la belleza sublime de la naturaleza y de la humanidad. Converso con el olvido es un amor espiritual a España, tierra de mis amigos del Colegio Loyola, que me obligaron a colaborar con ellos un día para dar a la luz aquel numero de aquella revista que bautizamos humildemente La Buhardilla, y que llevó a cabo publicar mi diván Converso con el olvido como una huella que quedara grabada en el recuerdo. 
La estética de Converso es hispano-árabe-bereber, porque allí se encuentra el Hoggar y el desierto, como se encuentra Castilla y La Mancha y los ecos de Antonio Machado, mi poeta preferido. Es una estética natural, campesina, que hace recordar mi infancia en aquel pueblo lejano durante la emigración forzada. Converso con el olvido es una mano tendida a los poetas españoles.

7) En CUANTO A SU OBRA EN ÁRABE, ¿CUÁL ES LA ESTÉTICA QUE FOMENTA Y CÓMO PUEDE SITUARSE SU PRODUCCIÓN DENTRO DE LA LITERATURA ÁRABE ACTUAL?

Mi obra es variante, primero como poeta argelino y árabe de la generación de los años setenta del siglo veinte. Al principio fui poeta clásico, vista la influencia de mis profesores, y del aprendizaje de memoria de miles de versos de la poesía árabe clásica y, sobre todo, beduina preislámica. Y todo esto culminó con mi teoría poética, que defiende el poema clásico (con métrica y rima) en un manifiesto como prólogo a mi segundo libro de poesías titulado Tahazzaba al-Ichko ya Layla. Este manifiesto quería decir que la innovación del poema clásico no consiste en dejar la métrica y la rima clásica - como dijo la poetisa innovadora, la iraquí Nazik al-Malaika en su teoría-, sino la innovación consiste en crear una lengua nueva y una metáfora irracional. Ésta fue mi teoría en resumen, y de allí hice una llamada a los poetas argelinos para que buscasen en la poesía mística y su experiencia con la lengua árabe, y también tener en cuenta las innovaciones en la poesía europea.

Mi segunda etapa es la etapa europea, que se debe a la influencia directa de la poesía española, influencia poética e influencia de la crítica literaria. La influencia de la crítica literaria me vino de mi maestro Emilio García Gómez en su lectura racional de la poesía árabe en general y andalusí en especial. En cuanto a la poesía modernista, reconozco que el gran teórico y 
poeta Carlos Bousoño me hizo definir de una manera clara y decisiva la diferencia entre la estética antigua y la estética moderna, además de su fabulosa teoría del Racionalismo verbal en la Poesía. Con este entendimiento llegué a escribir mi segunda teoría, que se encuentra como prólogo de mi libro de poesía/diván titulado al-Barzaj wa-Sikkin, libro galardonado para la Fundación del-Babtain como «Mejor Diván de la Poesía Árabe Moderna». Es el único libro de poesía galardonado en Argelia por dicha Fundación, por lo cual recibí una larga carta de felicitación por parte del Presidente Bouteflika en 2002.

Mi tercera etapa es la etapa del "Poema espiritual", que puede encontrarse en mi libro de poesía/diván titulado Antiko an al-hawaa, con un prólogo que define mi nueva visión de lo que es poesía.

8) En el Magreb la literatura marRoduí en lengua espaNOLA TIENE UNA NOTABLE TRADICIÓN, UNA NÓMINA DE AUTORES BASTANTE NUMEROSA Y UNA VITALIDAD CRÍTICA Y LECTORA. EN ARgELIA NO SE ENCUENTRA UN FENÓMENO SIMILAR, A PESAR DE LA VINCULACIÓN CULTURAL, TANTO ANDALUSÍ COMO ESPAÑOLA. ¿SE PUEDE HABLAR DE UNA "LITERATURA HISPANOARGELINA", O "LITERATURA ARGELINA EN LENGUA ESPAÑOLA"? ¿EN QUÉ SITUACIÓN SE ENCUENTRA?

El contacto histórico entre Argelia y España empezó con la llegada del conquistador argelino Táriq ben Ziyad en 711. Este guerrero es de la tribu de Walhasa, de la región de Tremecén del oeste de Argelia, y la gran mayoría de su ejército eran bereberes de las tribus de Sanhaja y Zenata. Desde aquel tiempo fue el primer contacto directo de argelinos con españoles, y después de la llegada de los árabes con Musa ben Nusayr y Buldg ben Bicho, ocurrió la repartición de España entre árabes y bereberes, y según las fuentes fidedignas, la parte sur fue poblada casi para los árabes y la parte norte (Castilla y Aragón, etc.) fue po- 
blada para bereberes argelinos. Digo argelinos porque el ejército del conquistador Táriq es fruto del ejercito del jefe bereber argelino Kusayla al-Awrabi, que asesinó al conquistador árabe Okba ben Nafia cerca de Biskra, y de la Kahina, reina del Aures, que tenía su capital en Tahuda. De allí tuvo el primer contacto que duró ocho siglos de convivencia, y confrontación e intercambio cultural y social, por eso dijo el musicólogo argelino al-Tifachi, natural del pueblo de Tifach cerca de Souk Ahras al este de Argelia, en su obra, que el gran maestro Ibn Bayya del siglo doce hizo una fusión mágica al mezclar música española cristiana con música bereber y árabe, y salió con lo que llamamos hoy día en todo el Magreb "música andalusí" por excelencia, y no fue Ziryab de oriente el verdadero creador de la música andalusí, porque este último no hizo nada más que divulgar la música de su maestro al-Mawsili de Bagdad. Por eso hoy día hay una semejanza entre la música español y la música magrebí.

Este contacto tuvo la suerte de empezar otra vez con la llegada de los españoles a principios del siglo dieciséis (1505), donde fue el segundo contacto desde Orán, que duró 300 anos, de convivencia y confrontación, por eso encontramos hoy día mucha tradición española en la vida de los argelinos del oeste de Argelia. Y durante esta larga estancia pudo Cervantes, según mi lectura propia - que he desarrollado en la introducción de mi libro Vida y obra de Barbarroja-, evocar aquel nombre raro del morisco llamado Sidi Hamete Benenjali, que creo era un personaje verídico que vivió en la época de Barberousse (Keyridin Barbarroja), y fue uno de los descendientes del Reino de Koukou cerca de Argel, y fue un gran jefe aliado de Barbarous. Este personaje mítico es llamado Sidi Hamed Benlkadi, que un tiempo rompió su alianza con Barbarous y pudo echarle de Argel y gobernarla durante cinco años, y los ciudadanos de Argel recuerdan con amargura su dominación después de haber sido el aliado más cercano de Barberous. Y después de treinta años 
de su muerte, llegó Cervantes como cautivo a Argel (16751680), donde la gente seguía recordando las hazañas de Sidi Hamed Benlkadi, que pudo vencer al invencible Barbarroja. Creo que Cervantes encontró en este personaje novelístico lo que buscaba, vencedor del invencible Barbarroja, el enemigo número uno del reino de España y de la cristiandad. Por eso pudo Cervantes mencionar un tal personaje sin ser juzgado por la Inquisición de entonces, y para conmemorar su valentía en Lepanto como buen cristiano. Así hizo también cuando dio la palabra para contar las amarguras de los moriscos a un personaje verídico granadino que se llamaba al-Rakute, a quien le dio la palabra en la novela El Quijote para quejarse en nombre de los oprimidos moriscos. El personaje evocado en El Quijote vivió en tiempos de Alfonso X el Sabio y del rey Muhammad II de Granada, y tenemos muchas noticias sobre este sabio de Ricate en la obra de Ibn al-Jatib. Por eso creo que Sidi Hameti Benenjali es nada mas que Sidi Hamed Benelkadi originario de Bugía y perteneciente a la famosa familia bereber de Ghoubrini.

En Argelia los españoles y los moriscos han dejado muchas huellas en la toponimia de la geografía de Argelia, como el famoso barrio de Argel llamado Taghara que significa tegríes ("los fronterizos").

Después de esta larga presencia llegó la tercera presencia de españoles en Argelia con la colonización francesa durante 1830 hasta 1962, una presencia que siguió también durante la independencia con emigrantes españoles que huyeron del régimen franquista hasta su muerte en 1975. Pero esta presencia fue muy limitada y, sobre todo, durante la época colonial francesa, que fue una colonización cultural y racial, por eso fueron escasos los hispanistas en Argelia. Lo que se cuenta son los becarios argelinos que tuvieron la ocasión de estudiar en España desde los años ochenta del siglo pasado, como Benhamamuch Fátima, 
Kamal Berragda, Abi Ayad, Ismat Turki, Salah Negaoui, Ghawti Kiyat, Bensnousi Ghania...

En cuanto a mi labor de hispanista, al volverme de Madrid en 1980, tuve que dar seminarios como profesor visitante en el departamento de español de la Universidad de Argel y de Orán durante años, y dirigí muchas tesinas y tesis en dichos departamentos. Fueron mis estudiantes de magisterios y doctorados Fatima Ben Hamamouch y Abi-Ayad y Ghania Bensnousi y Salah Negaoui y Ghawti Kiyat y Barbara y otros más...

En Constantina llegué a dar a la luz en la Facultad de Lengua un departamento de español con una iniciativa propia y, después de cuatro años de existencia, y con una promoción de licenciados, hoy día son maestros de español en los liceos. La decisión del Rector de la Universidad de Constantino dio fin al Departamento de español por falta de ayuda de España y falta de lectores de español durante la década negra del terrorismo en Argelia. Así, el rectorado de la Universidad de Constantino cerró el departamento por razón del terrorismo y falta de cooperación con países de habla hispana, y falta de profesores especialistas en español.

9) ¿CUÁles son SUS ACtUales PROYeCtos?

En cuanto a mi labor de traducción, consiste en traducir del español al árabe y del francés al árabe. Dirijo por más de diez años un centro llamado «Laboratorio de traducción en literatura y lingüística». En Argelia la crítica literaria me considera como el primer intelectual que introdujo la literatura española y latinoamericana en Argelia, y el primero que hizo conocer a García Márquez y su realismo mítico en el mundo árabe.

Otro aspecto en mis estudios es la edición crítica de manuscritos y, sobre todo, de obras andalusíes. He editado hasta hoy ocho obras. He escrito obras de literatura árabe en general y literatura argelina antigua y moderna, obras históricas, como la 
Historia del Magreb y de Argelia, siendo la última La Epopeya de la historia de Constantina, que fue estrenada en la inauguración de Constantina como Capital de la cultura árabe el 16 de abril 2015. El último trabajo de traducción que estoy realizando ahora es la traducción de la obra de Martín de Riquer Aproximación al Quijote. 


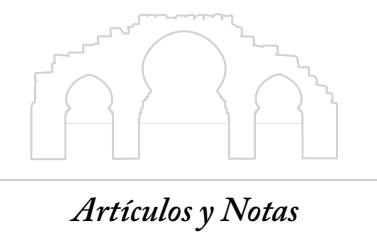





\section{ABDALLAH HAMMADI: \\ ÉTICA Y ESTÉTICA NEOANDALUSÍ}

IsAaC DONOSO

Universidad de Alicante

\section{ARGELIA, ESPAÑA Y LA PASIÓN POR AL-ANDALUS}

Existen personas fieles con su destino que son capaces de asumir en su propio cometido vital la culminación, el esfuerzo por llevar a cabo un fin que el tiempo impone. Los argelinos nacidos bajo la colonización francesa tuvieron que armarse física e intelectualmente para forjar una revolución, a sabiendas de que muchos perderían la vida en el intento. Los argelinos nacidos tras la Revolución no se encontraron ante ellos con un panorama más alentador, pues tenían que construir un país desde los cimientos, cimientos poco fiables tras una intervención colonial culturalmente alienante y socialmente agresiva. $\mathrm{Y}$ en ríos revueltos siempre pueden aparecer mensajes fáciles, salvapatrias, oportunistas o demagogos que establezcan un discurso intelectual interesado y orientado. De ahí la máxima exigencia que la sociedad que ha sido capaz de armar una revolución, revolución también en términos culturales, imponga a las mentes que deben trabajar por construir la identidad moderna de una naciente nación.

Argelia debía mirar al futuro pero, para hacerlo, debía levantar el edificio sobre cimientos sólidos, los cimientos que se fraguan cuando se asume el hecho y devenir históricos. Y éstas son las dos claves del imperativo ético que un intelectual de un país no alineado en los años setenta debía asumir: trabajo e historia o, en otras palabras, el incesante esfuerzo por reconstruir una narrativa histórica y rigurosa. $Y$, de nuevo, suele ser éste el esce- 
nario idóneo para formular un discurso postcolonial que quiera rendir cuentas con el colonialismo, de suerte que el discurso del colonizado acabe siendo tan interesado como el discurso del colonizador. No hay pensamiento que lo refleja más cabalmente que las máximas del escritor filipino José Rizal expuestas en su segunda novela El Filibusterismo (1891):

¿A qué darles libertad? ¡Con España y sin España serían siempre los mismos, y acaso, acaso peores! ¿A qué la independencia si los esclavos de hoy serán los tiranos de mañana? ¡Y lo serán sin duda porque ama la tiranía quien se somete a ella! ${ }^{1}$

De ahí la exigencia, también histórica, que la sociedad debe de tributar a aquellas mentes que se han dedicado, con honestidad intelectual y trabajo riguroso, a enaltecer la libertad que el conocimiento otorga. Creemos que éste es el caso de Abdallah Hammadi. Y lo es no sólo para el caso de Argelia, para una Argelia postcolonial que necesitaba profesores universitarios, arabistas, filólogos, pensadores, críticos literarios, poetas, novelistas, traductores e historiadores. Todo esto ha sido Abdallah Hammadi para Argelia. Sino también, como decimos, para el caso de España, para una España tardofranquista, cerrada al mundo, pero que necesitaba exportar la inmensa cultura que poseía en frascos de alcanfor. Y entre la exigencia por redactar una nueva historia de Argelia, y el gusto por estudiar la cultura española, apareció el punto de encuentro inevitable: al-Andalus como pasado de ambos, y futuro necesario:

¿Qué diré del al-Andalus de mis entrañas y de las primeras citas entre naranjos y olivos? ¿Conserva acaso el perfume de

${ }^{1}$ José Rizal, El Filibusterismo, edición crítica de Isaac Donoso, traducción filipina de Virgilio Almario, prólogo de Floro Quibuyen, Quezon City, Vibal Foundation (en prensa), cap. xxxix. 
la espada de Táriq, o la locura del Parnaso adornado de hojas de laurel y espectros de alas tornasoladas que acarician lo imposible? ¿Es quizás al-Andalus las norias asomadas a los miradores del Tajo y los arcaduces cuyo incesante regar llega a los oídos de los sedientos y de los que caminan en la certidumbre? Es el reino de los enamorados que escuchan el susurro de las tardes escondidas tras las murallas que despuntan más allá de la majestad y cuyo telón cae sobre las torres de Sevilla mientras se dispone a desdoblar los pañuelos de Rumaykiyya cuando celebra la estación de los almendros en flor y de la nieve que llega por los miradores del norte portadores del tañido de las campanas ${ }^{2}$.

Al-Andalus es un tópico manido, un concepto literario recurrente, un escapismo muchas veces fácil para el literato árabe ${ }^{3}$. Pero no creemos que sea éste el caso. Abdallah Hammadi no es un oriental, conoce perfectamente la sociedad y cultura españolas y, más que literato, se ha formado como filólogo e investigador con la mejor escuela de arabistas españoles. Lo andalusí no constituye un adorno, ni en su producción poética ni, indudablemente, en su labor científica. Pero para el Abdallah Hammadi que compone tan bellamente, tanto en español como en árabe, en esta introducción a su libro Al-Andalus entre el sueño y la realidad. Antología de la poesía española andaluza contemporánea (2008), al-Andalus va más allá del mito, para transformarse en una realidad rescatada del olvido.

$\mathrm{El}$ intelectual argelino debe guiarse por una ética, pero la

2 Abdallah Hammadi, “Al-Andalus entre el sueño y la realidad”, en $A n$ nales du Laboratoire de Traduction, Constantina, Universidad de Constantina, núm. 3, p. 7 (versión española del texto aparecido en Al-Andalus bayna alhulm wa-l-haqùqa. Anțūlü̂yìyā min al-šir al-isbānī al-andalusì al-mu'āṣar, Argel, Dār Bahā’ al-Dīn, 2008, p. 9).

3 Sigue siendo perfectamente válida la referencia de Pedro Martínez Montávez, Al-Andalus, España, en la literatura árabe contemporánea, Madrid, Mapfre, 1992. 
culminación debe de ser estética, o no será, o será otra cosa, será realismo proletario, compromiso mal entendido, cuentas pendientes con el colonizador, populismo, demagogia o, simplemente, malversación cultural. La construcción cultural no puede levantarse sobre el odio y el revanchismo, más bien al contrario, y así lo plantea Hammadi en la pregunta 3 de su encuesta a los poetas andaluces, la cual encabeza con el título «Llamada fraternal a los poetas andalusíes de hoy»:

$3^{\circ}$ En la época árabe de Al-Andalus, según narran los cronistas, la poesía llegó a ser algo como el pan de cada día, incluso entre campesinos y labradores; y así puntualiza el cronista Ibn Bassām en su Dajira que la poesía llegó a impregnarlo todo hasta el punto que si pides a un labrador, que va tras su arado, que te componga una poesía, te lo hace en el acto. ¿A qué se debe toda esta riqueza poética? ¿Cuál es el secreto en todo esto? Tal vez Al-Andalus por ser tierra de tanto encuentro y cruce cultural llegó a ser inspiradora como la mujer imposible que tanto cantan los poetas a través de la historia? ${ }^{4}$

La ética hammadiana yace en responder a las exigencias argelinas no con un mensaje revanchista, dogmático o politizado, sino con un mensaje cultural, además de la más alta cultura, la cultura andalusí, de la cual Argelia también fue heredera. Y para llegar a ese reducto de la memoria civilizacional, establece como primer paso la "conversión al olvido", casi a modo de intuición mística: Andalus al-ašrwāq / أندلس الاشواق lo llama Hammadi, "Deseo de al-Andalus", con un concepto que recuerda al Tarŷumān al-ašrwāq / نرجـمان الأشواق , "Intérprete de los deseos" del místico

${ }^{4}$ Abdallah Hammadi, "Al-Andalus entre el sueño y la realidad", loc. cit., p. 17 (versión española del texto aparecido en Al-Andalus bayna al-hulm wal-haqiqua, loc. cit., p. 35). 
andalusí Ibn 'Arabī:
¡El temporal de la soledad muerde el vacío de tu horizonte!
$\mathrm{Y}$ una frescura de arco iris cae en pesadillas en tu lecho nocturno.
¡Lejos de viento quedó tu arenal sin navío!
¡Qué sorbo de aroma te alivia!
¡Qué grito fantasmal se ve urgir entre las ventanas de tu abismo! ${ }^{5}$

Hammadi en este sentido no inventa el sentimiento, no ya de nostalgia, sino de encontrar en al-Andalus respuestas a la identidad árabe, en el recuerdo, en la memoria, en el olvido. Consecuentemente cita a Adonis:

Por eso dice Adonis en "La música del pez azul (p. 394)": "Me resulta difícil explicar mi relación con al-Andalus. Está ligada al recuerdo, al deseo, a los sueños. No sé qué veo en al-Andalus, pero es algo que no puedo transmitir. ¿Se ha convertido por eso en una segunda lengua? ¿En un texto original y global? ¿Habita en mi imaginación, formando un todo con ella? He hablado con al-Andalus como si se tratara de alguien ausente y presente a la vez a quien comunicar mis pensamientos. Y ella se limita a ser fuente de inspiración ${ }^{6}$.

Lo que sí inventa Hammadi, y lo hace no sólo suyo, sino también parte de argelinos y españoles, es esa recuperación de

${ }^{5}$ Abdallah Hammadi, Converso con el olvido, Constantina, Universidad de Constantina, 2003, p. 1.

${ }^{6}$ Abdallah Hammadi, "Al-Andalus entre el sueño y la realidad", loc. cit., p. 8. 
al-Andalus en clave moderna y viva, es decir, no sólo como ejercicio de arqueología filológica y crítica textual, sino también como "realismo mágico". Y para ello seguramente se haya servido de su conocimiento, excepcional dentro del mundo árabe, de la obra de Gabriel García Márquez y la literatura hispano-americana. Al-Andalus tiene que ser un lugar de la memoria, Macondo árabe que se recupere del olvido, para vivirse, en su cultura y su legado, en su sensibilidad y gusto estético. Hammadi es un intelectual, nada hay de nostalgia ni de reivindicación política en la idea de al-Andalus, idea usada y abusada por propios y extraños. La idea hammadiana es exclusivamente cultural, vivencial, para que la estética del gusto andalusí sea herramienta para la construcción moderna de argelinos y españoles. Y Estética es todo, el todo ontológico:

En virtud de lo anterior, la Estética ha de comprenderse en tanto que orden mayor de la universalidad cualitativa y unidad preferente de la universalidad, trabada en el todo de las conexiones, el Espíritu, entre el hombre, la naturaleza y la vida. La Estética se resuelve como una ontología; es una ontología cualitativa de la unidad y el todo. Una ontología dinámica que históricamente se mueve. La Estética se resuelve como la ontología; filosofía primera, que está en el centro ${ }^{7}$.

Tras la ética investigadora, académica y científica, Hammadi obra, escribe y poetiza, construye literatura que pueda funcionar en la definición ontológica del ser argelino, del ser español, de esa nueva poesía andaluza que llama al-šir al-isbāni al-andalusī / La idea es dar forma académica y literaria a una nueva estética andalusí/andaluza/española, desde la

\footnotetext{
${ }^{7}$ Pedro Aullón de Haro, "Estética y objeto estético", en Caracteres Literarios, 2001, p. 13.
} 
herencia argelina, al tiempo que responder a la necesidad ontológica de definir, también, una estética argelina con la cual afrontar los desafíos de la modernidad. De ahí que Hammadi escriba en español, pues el español le permite ser el eslabón de un continuum que sobrevive en la memoria, aquella historia que nació en la Granada de Ibn al-Jatịib, siguió desterrada en la Argel de Cervantes, y debe continuar en la Constantina de Hammadi:

\author{
Por tu trágica sin venganza \\ renunciaré a mi Sinhaya. \\ Por tus rosas del recuerdo \\ encarnaré a Abu-1-Hayyay. \\ Por tu sorda lejanía \\ resucitaré a Ibn al-Jatib. \\ Por tus torres brumosas \\ edificaré mis casidas. \\ Con azucenas y zureo levantaré tu al-mibrab. \\ Con mi sudor de zinati \\ y mi yegua berberisca \\ alcanzaré tu Ben Omaya. \\ Regaré tus arriates, tu ámbar de Oriente \\ con el treno de mi laúd de mirto. \\ Por el vino y el copero. \\ Por el mancebo y la Zumaya. \\ Por Badis y el Bermejo. \\ Te haré ofrenda, mi Constantina ${ }^{8}$.
}

De ahí que sea pertinente en la obra de Abdallah Hammadi establecer el concepto «neoandalusí» para el proyecto intelectual y literario que encarna. Frente a un colonialismo culturalmente agresivo que había alienado al argelino con su pasado mediante la sustitución lingüística y la diglosia, Hammadi encuentra en la lengua española una liberación y, sobre todo, una herramienta

\footnotetext{
${ }^{8}$ Abdallah Hammadi, Converso con el olvido, ob. cit., p. 31.
} 
con la que explorar, intuitivamente, al modo sufí, las estructuras cognitivas del ser y, en última instancia, comunicarse con el olvido.

Siempre navegando por el camino:

desde los confines del Hoggar, un vasto

pasto

de arenal me guía;

¡lamiendo el céfiro de un latido sereno!

Un río de cristal se vierte

hacia el infinito

En la otra orilla, dos siluetas de verde

clamor suplican el horizonte 9 .

Hammadi plantea la conversión, la extinción, el abandono al lugar más remoto del ser, donde habita el olvido. Cualquier lector español seguro que ya sabe de lo que Hammadi está hablando:

Donde habite el olvido,

En los vastos jardines sin aurora;

Donde yo sólo sea

Memoria de una piedra sepultada entre ortigas

Sobre la cual el viento escapa a sus insomnios.

Donde mi nombre deje

Al cuerpo que designa en brazos de los siglos,

Donde el deseo no exista.

Así comienza el famosísimo poema de Luis Cernuda "Donde habite el olvido", poeta andaluz que expresa la extinción del ser en el olvido. Hammadi realiza una operación similar, la de convertirse al olvido, allí donde al-Andalus es mito, para, una

\footnotetext{
${ }^{9}$ Ibid., p. 47.
} 
vez extinguido el deseo, devolverlo de hecho y por derecho a la realidad:

\author{
¡Ay hermano Federico! \\ Que he venido para sacudir de tu frente \\ el polvo del olvido para sembrar sobre tu losa \\ una flor \\ cuyo nombre es al-Andalus. \\ Hermano, \\ que hoy vengo para llevarme la ceniza de tus \\ huesos \\ y quemarla como incienso en el templo de \\ nuestra liberación sagrada ${ }^{10}$.
}

Hablamos por lo tanto de ética argelina y estética neoandalusí, del reto con el que el destino desafiaba a los intelectuales argelinos a partir de los años setenta, y de la solución andalusí, andaluza y española que logró encontrar Hammadi para responder al dilema. Era necesario encontrar una comunión con los escritores españoles contemporáneos, sobre todo con los andaluces. Al mismo tiempo era imperativo aprender la lengua de Cervantes, y cultivar el argelinismo en clave hispánica, o hispanoárabe. Suponía a la vez una liberación del yugo colonial, como una reivindicación de la memoria, la historia y el legado árabe en el Mediterráneo occidental. Converso con el olvido no es tan sólo un breve libro de poesías, ilocalizable, manuscrito perdido como la legendaria obra de Cide Hamete Benengeli. Converso con el olvido es sobre todo una obra fundacional dentro de las Letras Argelinas, pues no hay mayor rigor y coherencia en la historia de cualquier literatura que la continuidad, y en este caso la continuidad se logra con el símbolo argelino de uno de los mayores genios de la literatura universal:

\footnotetext{
${ }^{10}$ Ibid., p. 7.
} 


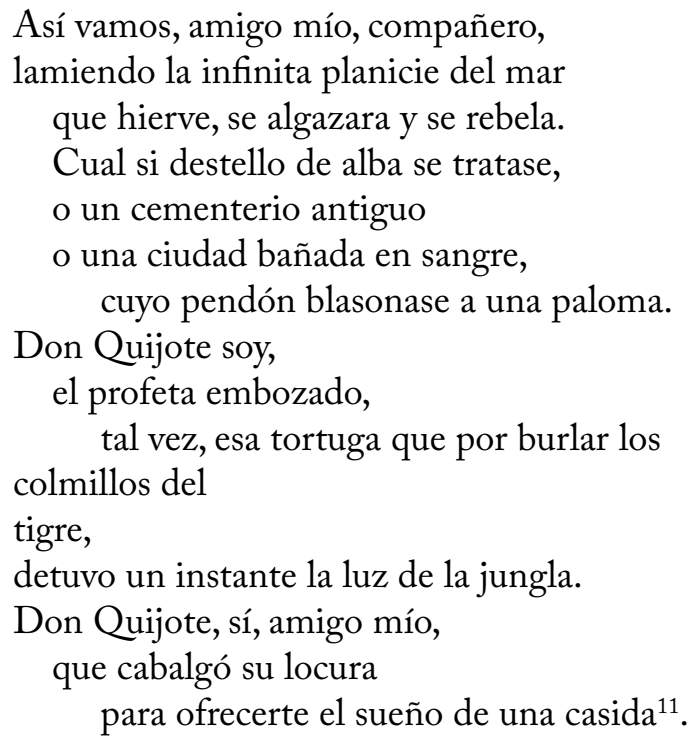

Converso con el olvido da por lo tanto continuidad a una literatura hispanoargelina que nunca fue pero siempre ha estado presente, como aquellos moriscos exiliados, como aquellos cautivos depauperados. Al-Andalus y España han estado siempre presentes en Argelia, pero sus voces se han relegado al olvido. Abdallah Hammadi regresa al olvido para rescatar esa voz, para convertirse en esa voz, de morisco nuevo, de neoandalusí, como si el continuum histórico nunca se hubiera detenido.

Lo curioso de esta historia, y lo trágico, es que el esfuerzo de Abdallah Hammadi acabó igualmente en el olvido, como toda esa literatura morisca, clandestina y cifrada. Converso con el olvido es intrascendental para la historia de las literaturas hispánicas, no ha sido valorado como obra fundacional de una "literatura hispanoargelina contemporánea”, y ha pasado desapercibida tanto para la crítica como para la historia literaria. Peor aún,

${ }^{11}$ Ibid., p. 40. 
Abdallah Hammadi parece no haber recibido el reconocimiento que merece por parte del Hispanismo y el Arabismo español.

Este pequeño trabajo, incluido en un número homenaje dedicado a su figura y obra en Revista Argelina. Revista semestral de Estudios Argelinos, pretende ser una guía para adentrarse en la obra de Abdallah Hammadi, y revalorizar su contribución a la literatura argelina, la literatura hispánica, la historia y crítica literarias, la filología, el Arabismo y el Hispanismo.

\section{BIBLIOGRAFÍA HAMMADIANA}

Se relacionan a continuación las principales obras de Abdallah Hammadi, tanto en lengua árabe como española, por orden cronológico y divididas entre obras literarias y académicas. Se indica entre corchetes los títulos en español de las obras en árabe:

\section{OBRAS LITERARIAS:}

1) Converso con el olvido, Madrid, La Buhardilla, 1979 (2a edición: Constantina, Universidad de Constantina, 2003).

2) Al-biŷra ilà mudun al-ŷunūb [Emigración hacia las ciudades del sur], Argel, SNED, 1981.

3) Qașāid gaŷariyya [Poemas gitanos], Argel, ENAL, 1983.

4) Tahazzaba al-išq yā Laylà [Oh Leila, la pasión sobreviene], Constantina, al-Ba'aț, 1985.

5) Al-Barzaj wa-l-Sikkin [Umbral y Cuchillo], Damasco, Ministerio Sirio de Cultura, 1998 (2a edición Argel, Dār Huma, 2002; $3^{a}$ edición Constantina, Universidad de Constantina, 
2004; 4a edición Constantina, Dār al-Alma'iyya, 2010; y 5a edición Constantina, Casa Numidia, 2016).

6) Tafunasit, novela, Argel, ENAL, 2006.

7) Unțq 'an al-hawà [Háblanos desde las vísceras], Constantina, Dār al-Alma'iyya, 2011.

OBRAS ACADÉMICAS:

1) Gābriyāl Gārsiyā Mārkìz. Rä̀id al-wāqa ìyya al-sahriyya [Gabriel García Márquez. Pionero del Realismo Mágico], Argel, ENAL, 1983.

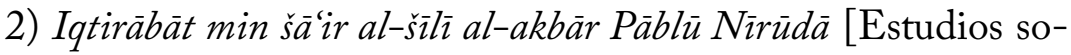
bre el gran poeta chileno Pablo Neruda], Argel \& Túnez, SNED \& MTED, 1985.

3) Madjal ilà al-šìr al-isbānī al-mu'ạșar [Introducción a la poesía española contemporánea], Argel, ENAL, 1985.

4) Dirāsāt fì al-adab al-magribì al-qadìm [Estudios sobre la antigua literatura magrebí], Constantina, al-Ba'ath, 1986.

5) Al-Müriskyūn wa muhākim al-taftì̌ fì al-Andalus. 1492-1616 [Los moriscos y la Inquisición española. 1492-1616], Argel \& Túnez, SNED \& MTED, 1989.

6) Masālāàt fì al-fikr wa-l-adab [Preguntas sobre pensamiento y literatura], Argel, Departamento de publicaciones universitarias, 1994.

7) Al-haraka al-țalābiyya al-ŷazāiriyya. 1871-1962 [Movimiento de los Estudiantes Argelinos. 1871-1962, Argel, Museo Nacional de los Mártires, 1994. 
8) Tuhfat al-Ijwān fì tabrīm al-dujān li-'Abd al-Qūdir al-Rāšidì al-Qusanțin̄i, edición de Abdallah Hammadi, Beirut, Dār algarb al-islamī, 1997.

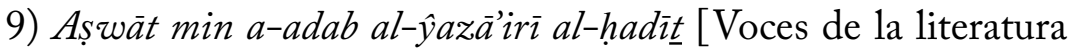
argelina contemporánea], Constantina, Universidad de Constantina, 2000.

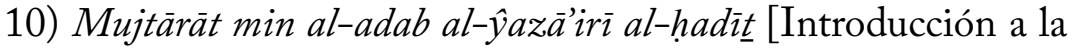
poesía argelina contemporánea], Kuwait, Fundación Babtain, 2001.

11) Al-šíriyya al-'arabiyya bayna al-ittibā'wa-l-ibtidād [La poética árabe entre el conservadurismo y la innovación], Constantina, Universidad de Constantina, 2001.

12) Andalusiyyāt. Garnāta wa-l-šir [Andalusíes. Granada y la poesía], Constantina, al-Ba'at, 2004.

13) La poesia en el reino nazari de Granada. 1232-1492, Kuwait, Fundación Babtain, 2004.

14) Rịhla Muhammad al-Zāhì al-Millī min Pārìs ilà Qusanțina [Viaje de Muḥammad al-Zāhī al-Millī de París a Constantina], edición de Abdallah Hammadi, Constantina, al-Ba'aț, 2004.

15) Fukāhāt al-asmār wa madhabāt al-ajbār wa-1-ašār li-Ibn Hudayl [Diversiones nocturnas y noticias de escuelas poéticas de Ibn Hudayl de Granada], Kuwait, Fundación Babtain, 2004.

16) Dīwān Ahmad al-Gwālmī [Obra poética del poeta argelino Aḥmad al-Gwālmī], edición de Abdallah Hammadi, Argel, Ministerio argelino de la cultura, 2005.

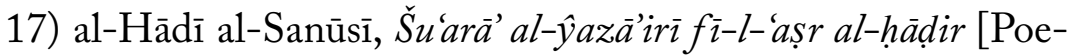
tas argelinos de nuestros días], edición moderna de Abdallah 
Hammadi Constantina, Dār Bahāa al-Dīn li-1-Našr wa-1-Taw$\mathrm{z}^{\prime}{ }^{\prime}, 2007,2$ vols.

18) Al-Andalus bayna al-hulm wa-l-ḩaqiqa. Anțūlūŷìyā min alšîr al-isbānì al-andalusī al-mu'āsar [Al-Andalus entre el sueño y la realidad. Antología de la poesía española andaluza contemporánea], Argel, Dār Bahā’ al-Dīn, 2008.

19) Sìra al-Muȳāhid Jayr al-Dīn Barbarūs fì al-ŶYazāìr [Vida de Jeireddín Barbarroja en Argelia], Argel, Dār al-Qaṣba, 2009.

20) Al-Ŷazä̀ir al-faransiyya min munzūr ahd al-ahālì li-mu'alifibi al-šarîf Ibn Habìlis [La Argelia francesa vista por un indígena, de Ben Hbiles], Argel, Dār Bahā’al-Dīn, 2009.

21) Târìj balad Qusanțina li Ibn al-Ațār [Historia de la ciudad de Constantina de Ibn al-'Ațār], Argel, Ministerio de Cultura, 2011.

22) Al-durr al-munazzim fì al-mawlud al-nabuwwī al-mu'ażim li-l-imām al-'Azafī [Perla ordenada del natalicio del más grande de los profetas], Amán, Dār al-Yāzūrī, 2015.

23) Malhama tārìj Qusanțina [Epopeya de la historia de Constantina], Argel, 2016. 


\section{APÉNDICE ICONOGRÁFICO}

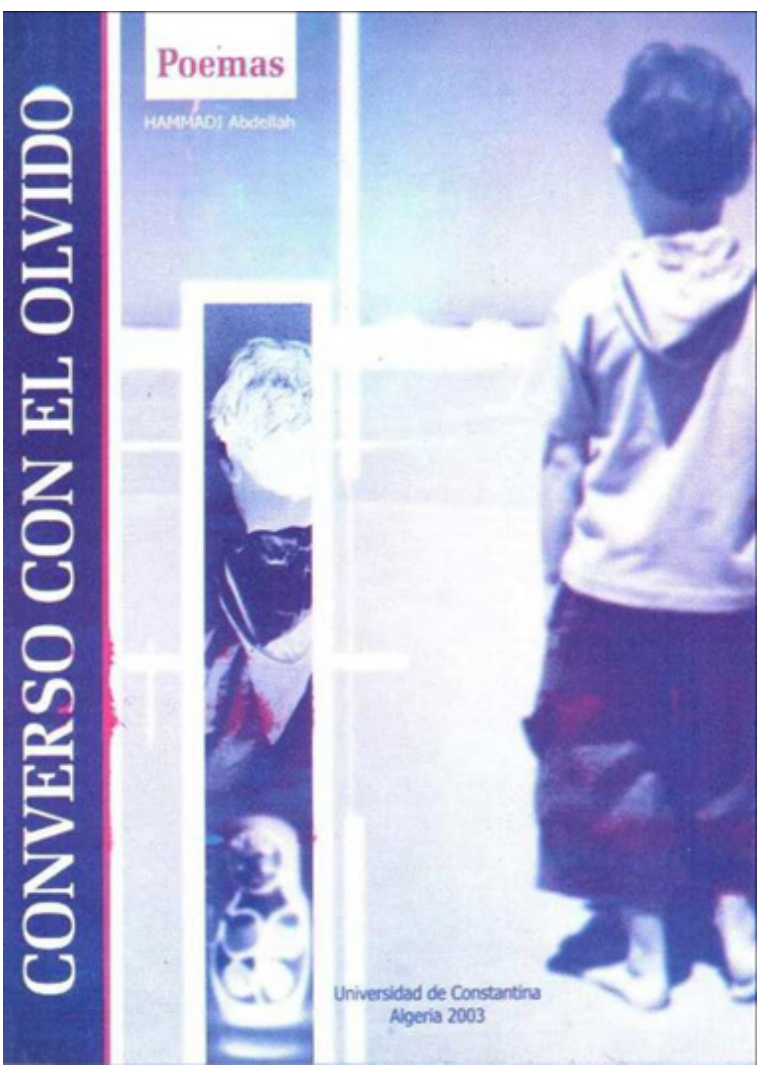


حمَاري عَبدانه
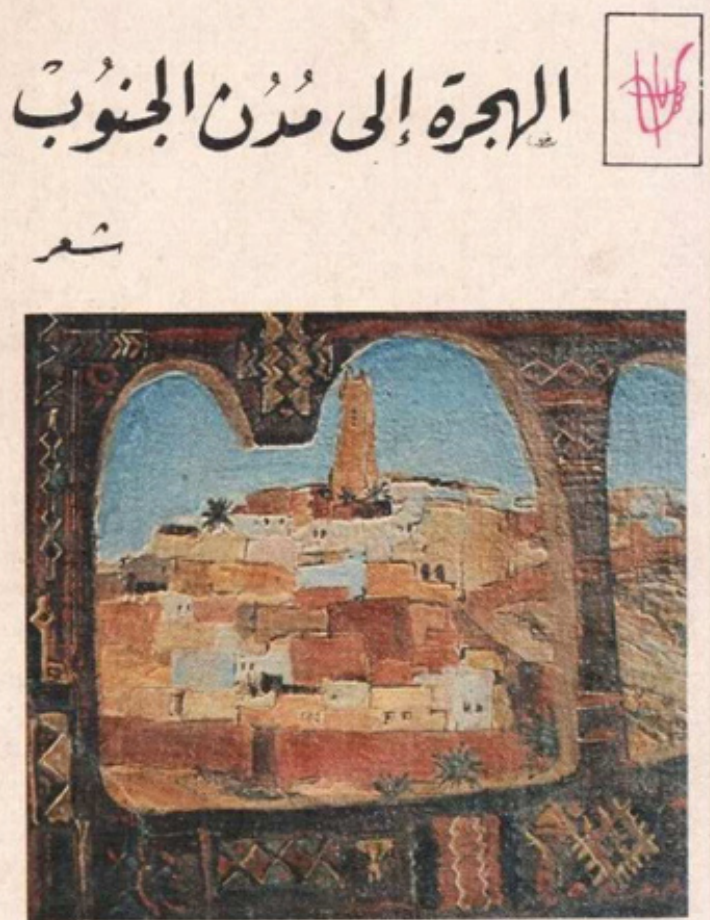

Ap 


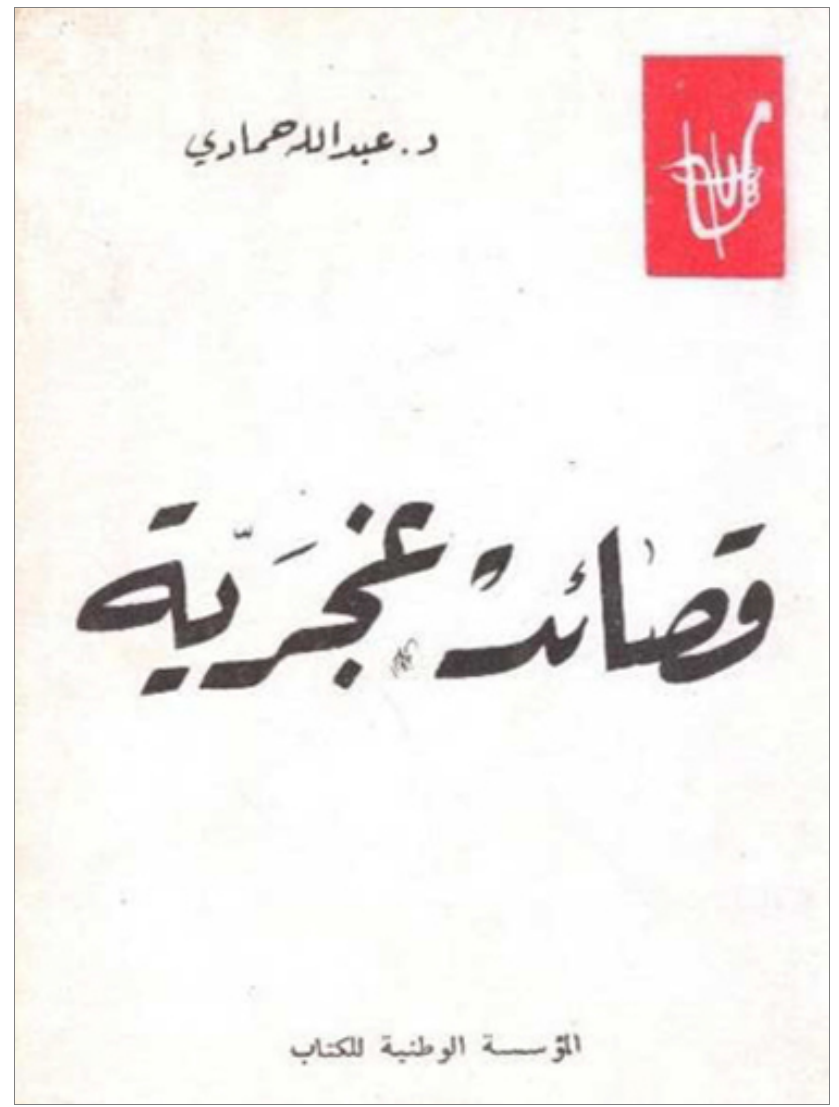




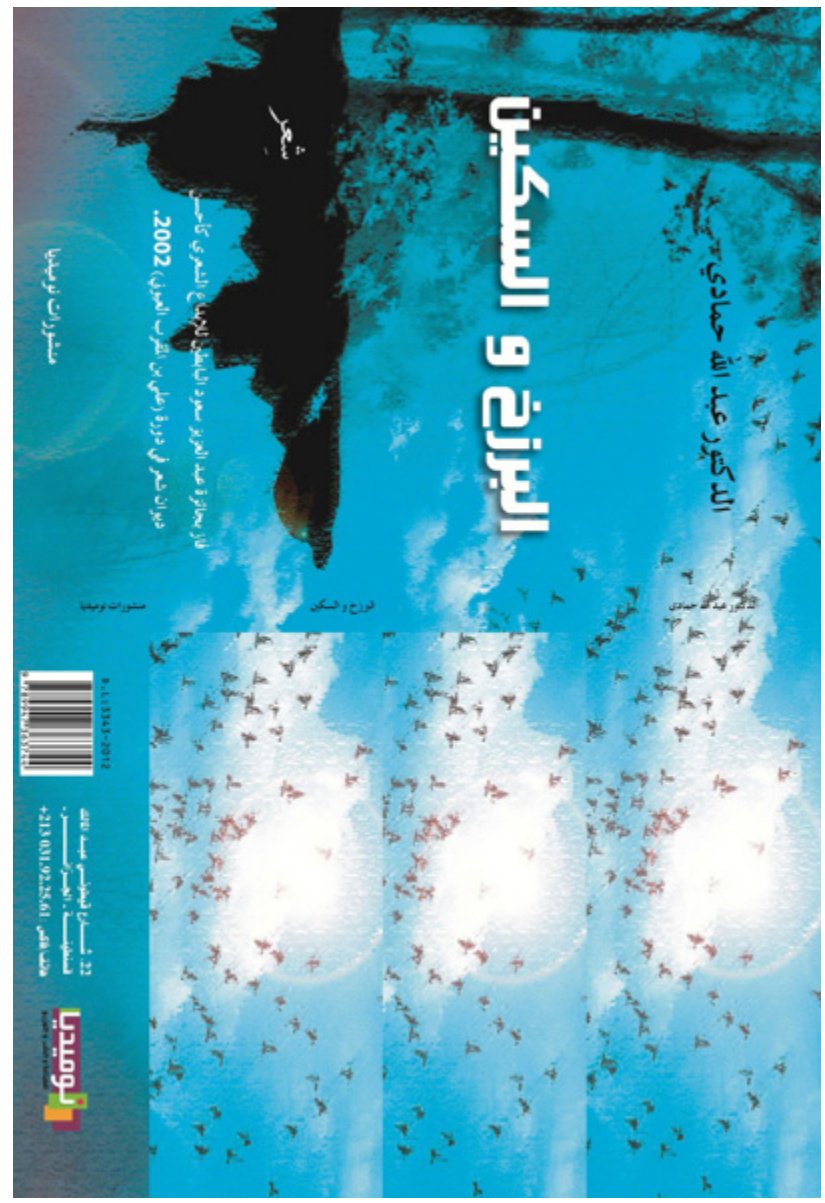




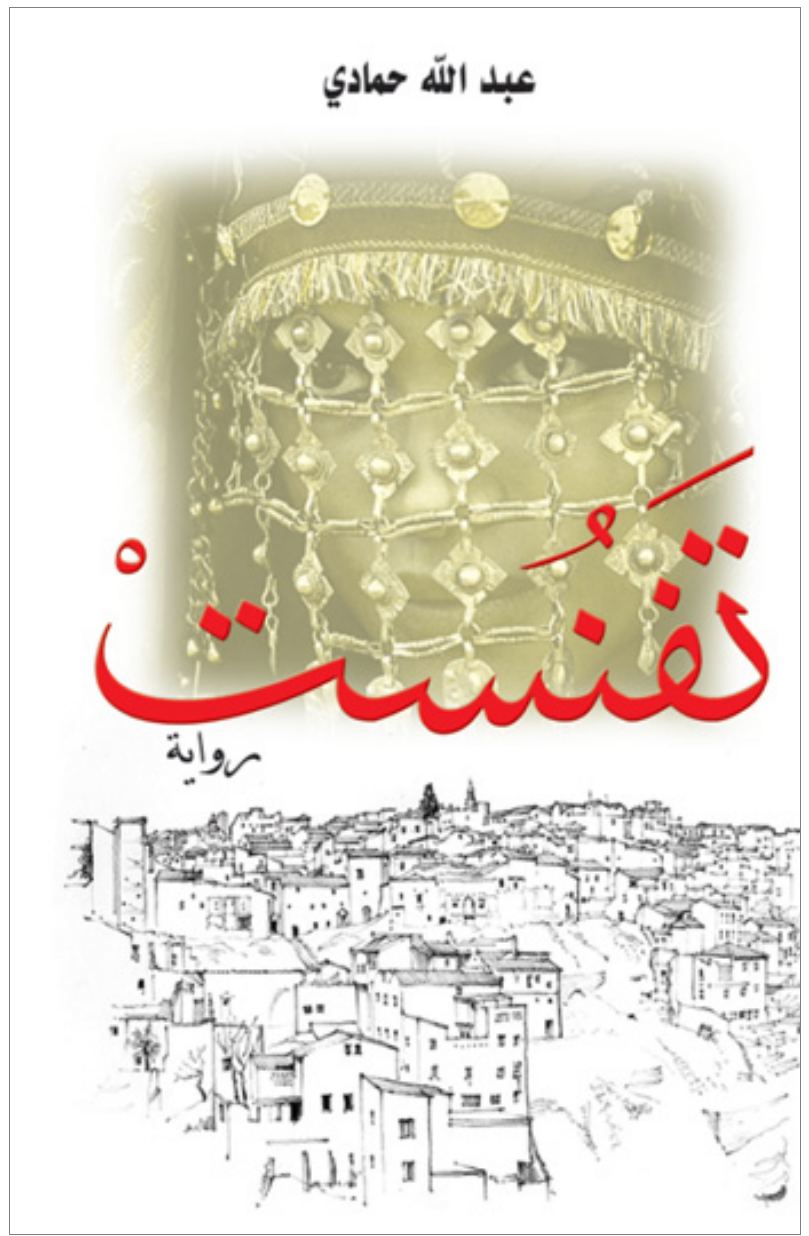




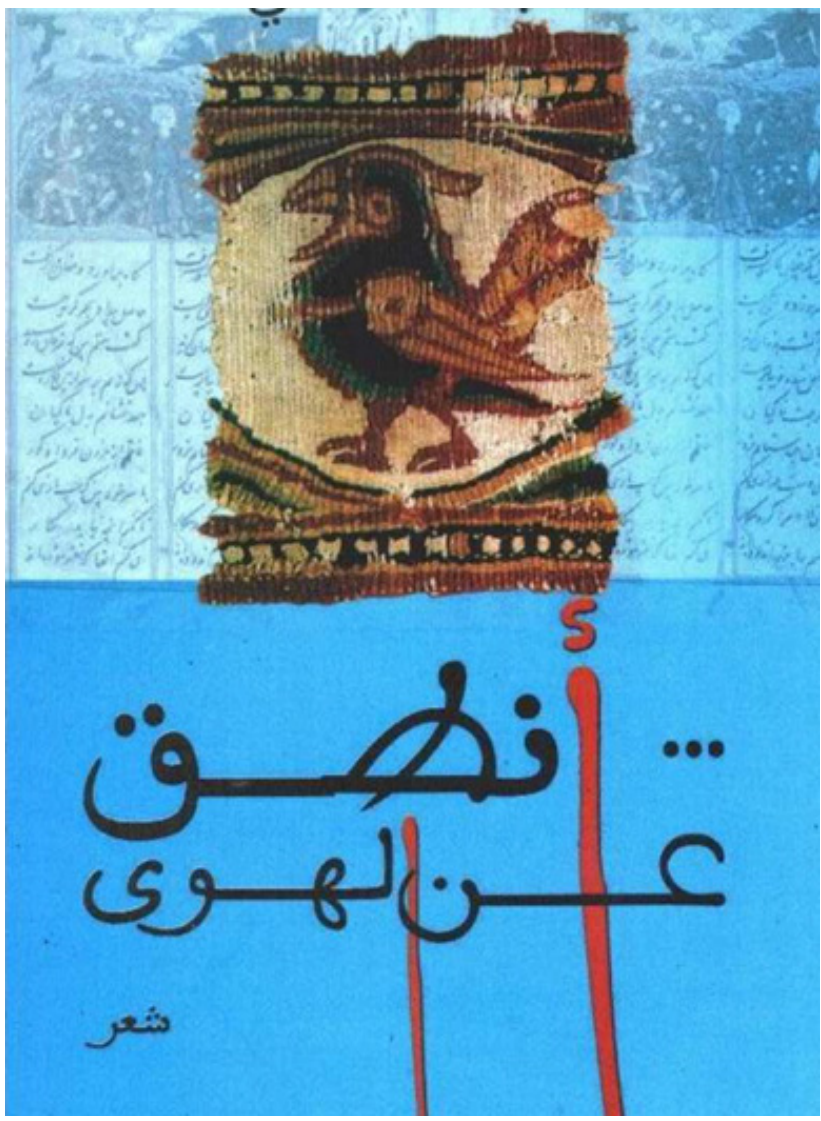




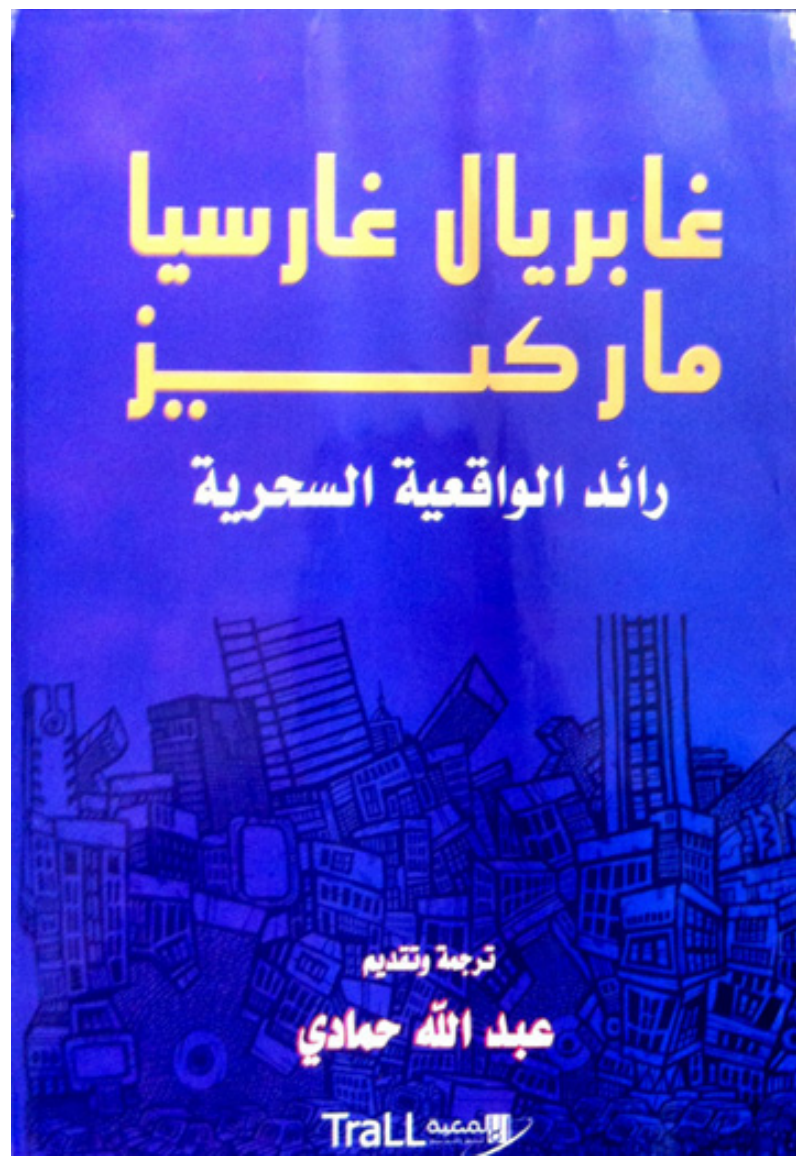




\section{عبلد الآله حمادي}

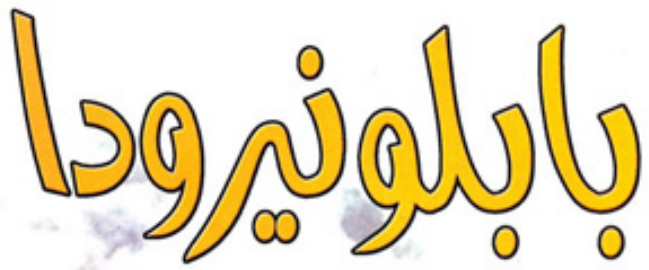

Jy

(مقارية نقيةهة)

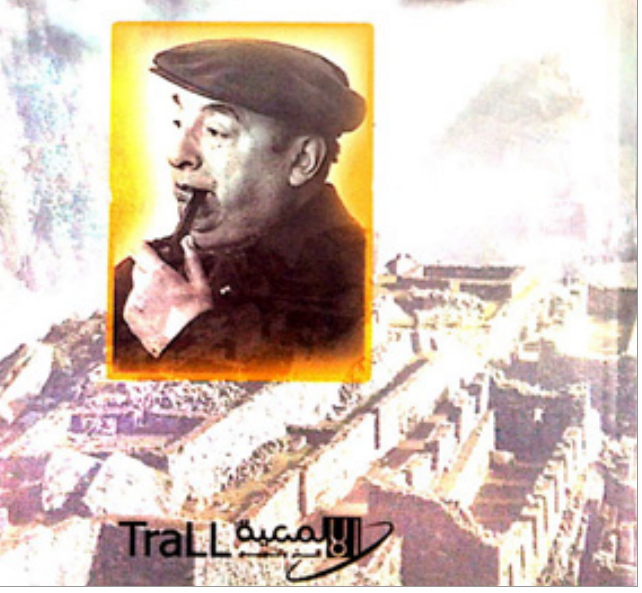




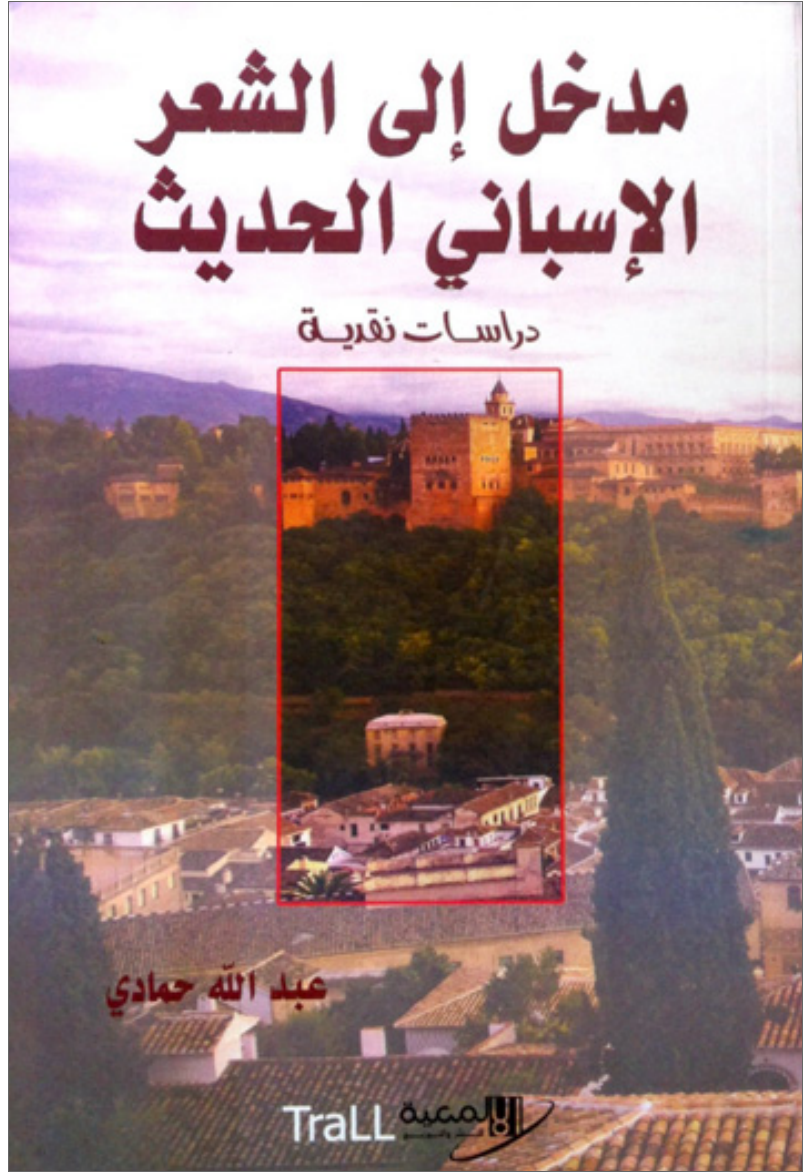




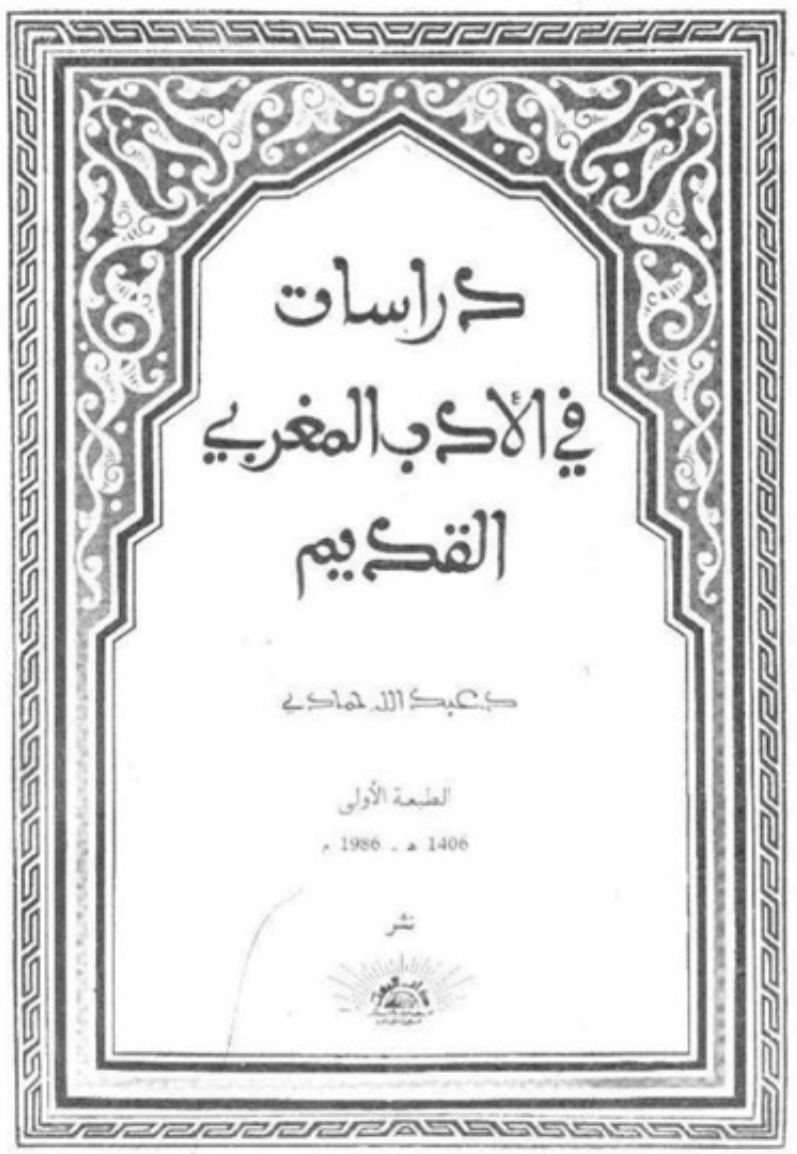



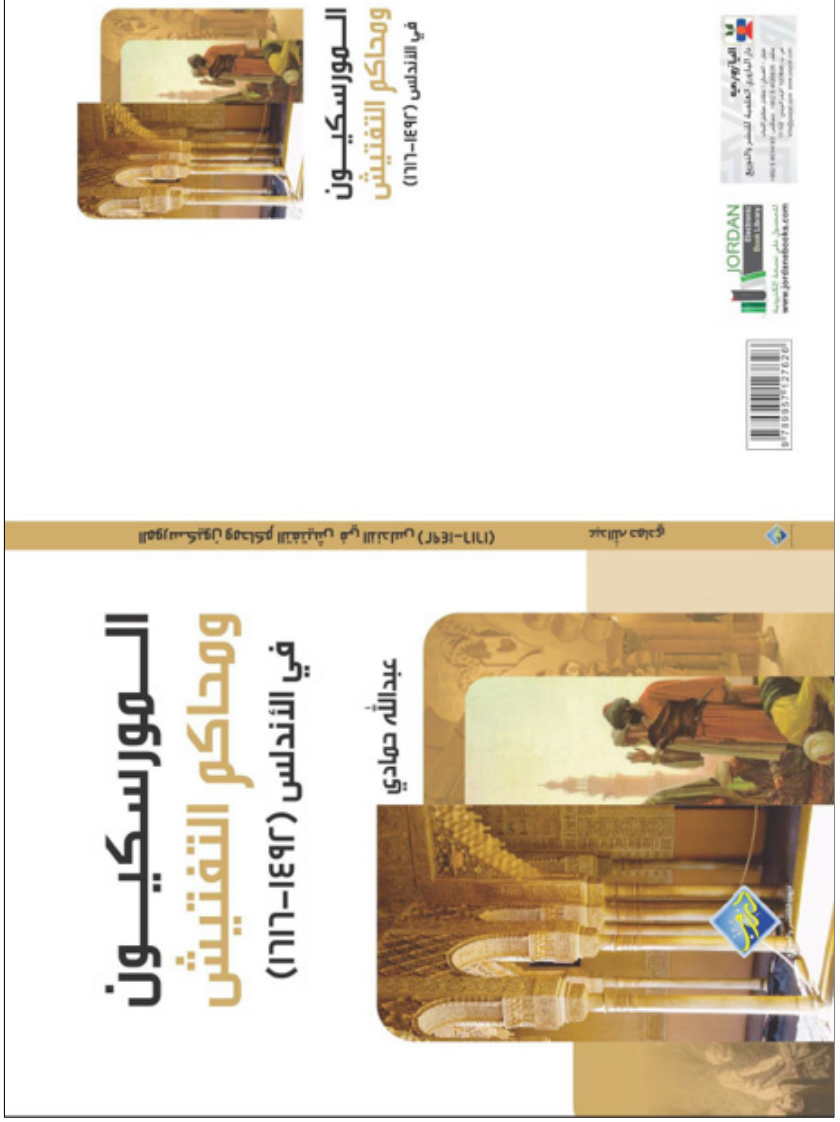


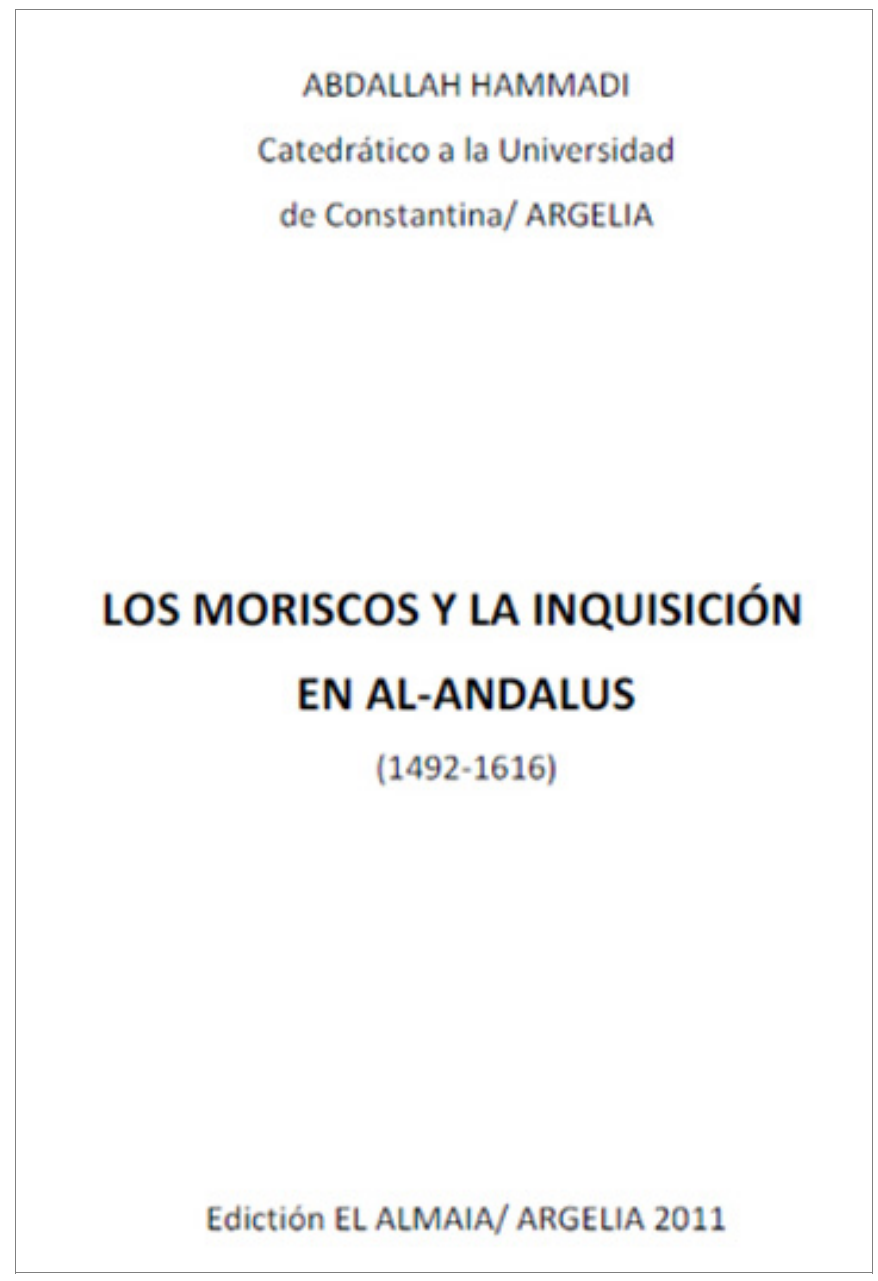




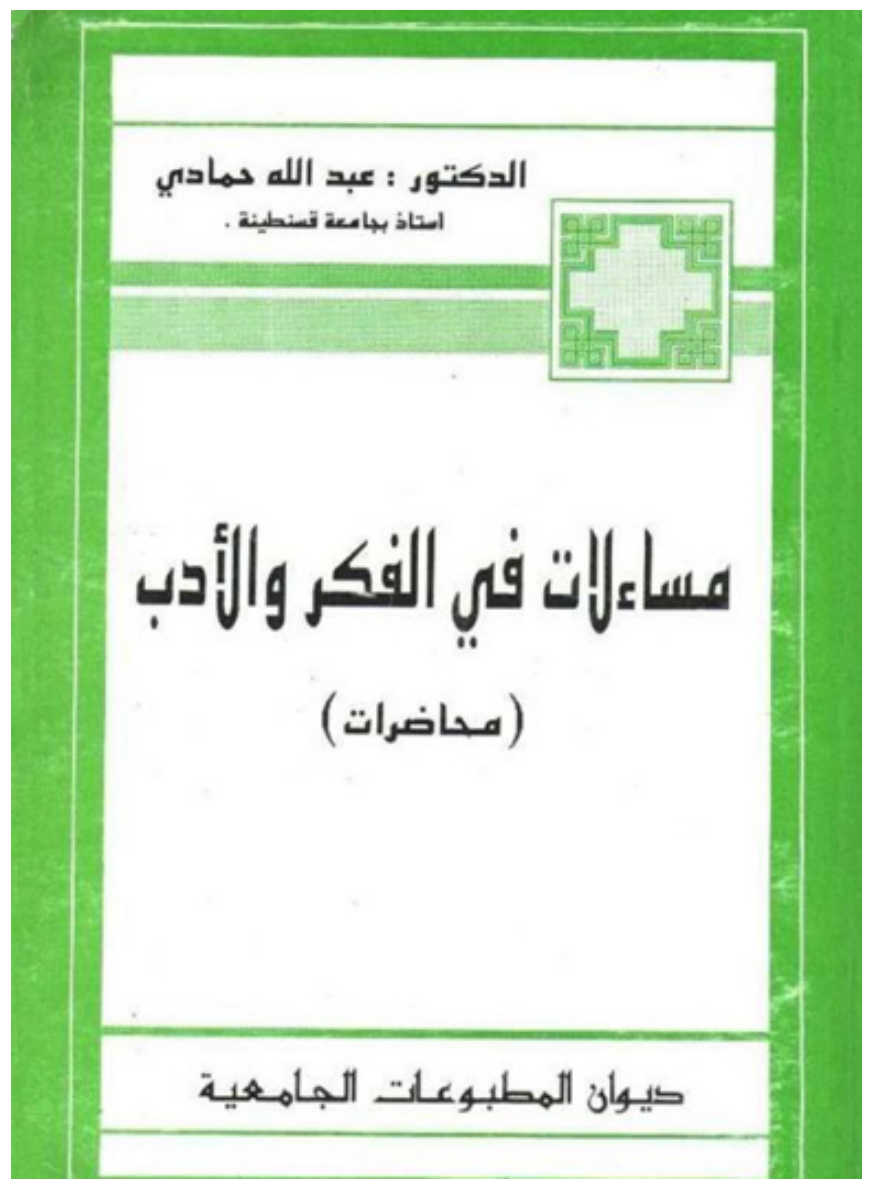




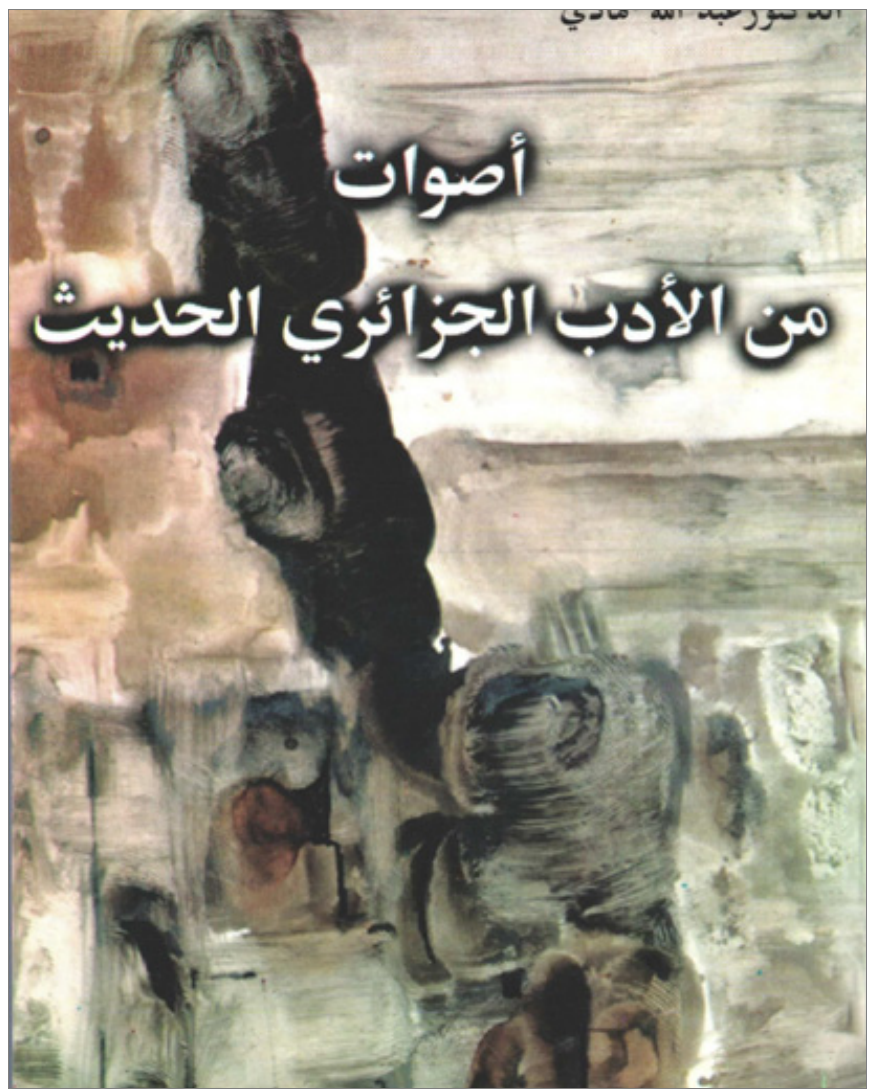




\section{כ. عبد الله هماطيى}
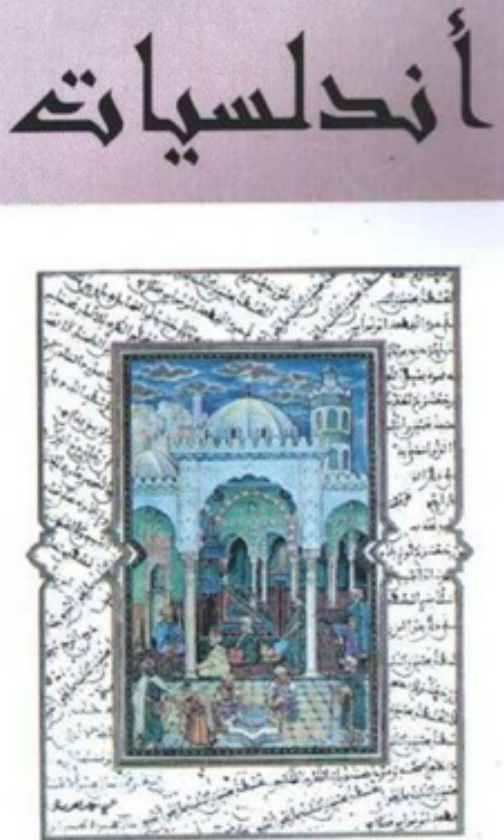


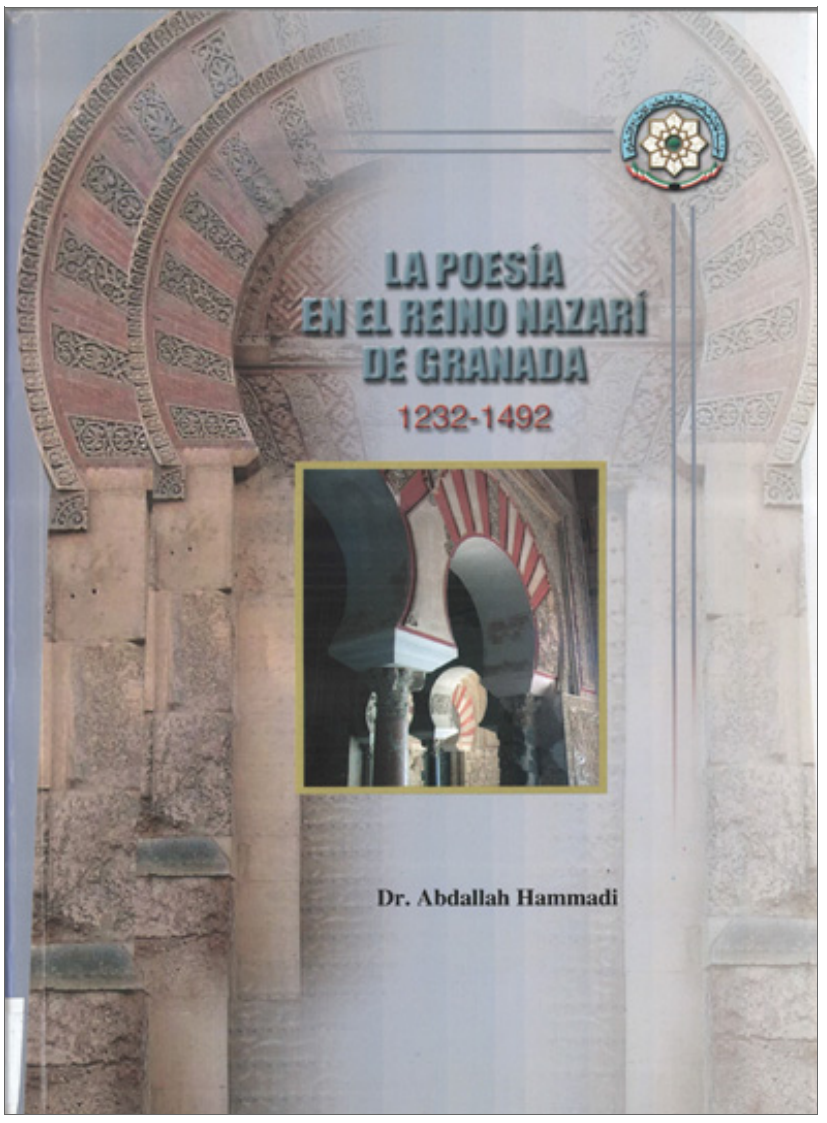




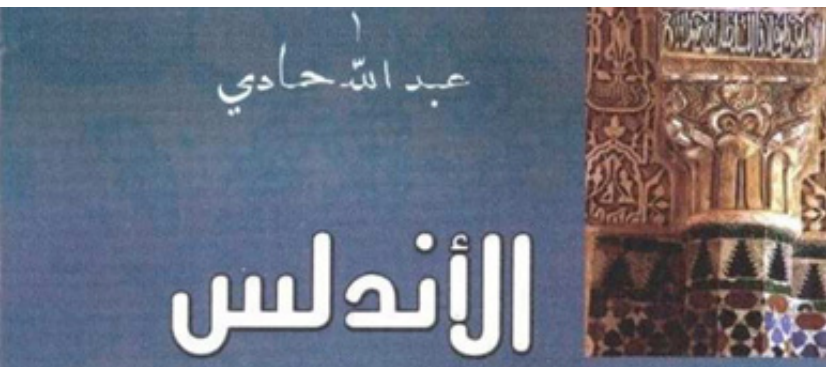
بين|لحفع والحميمة.

$$
\text { أنطولوجيا ين الشع الإسباني الأندلي العاصر }
$$

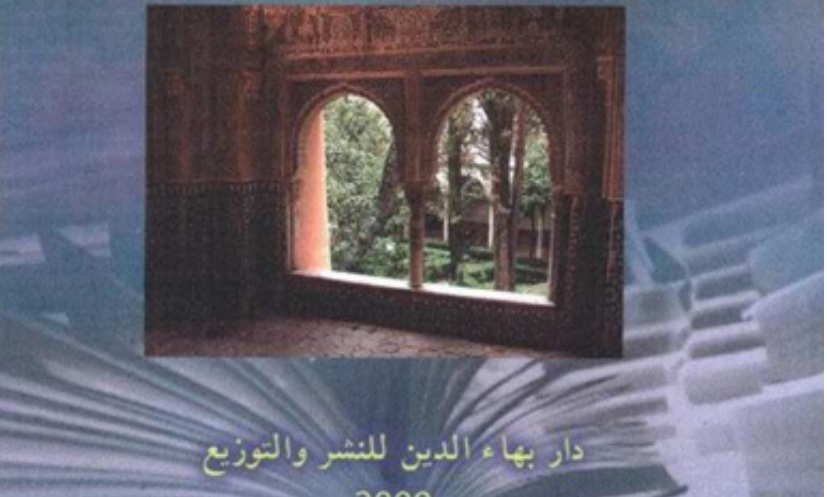




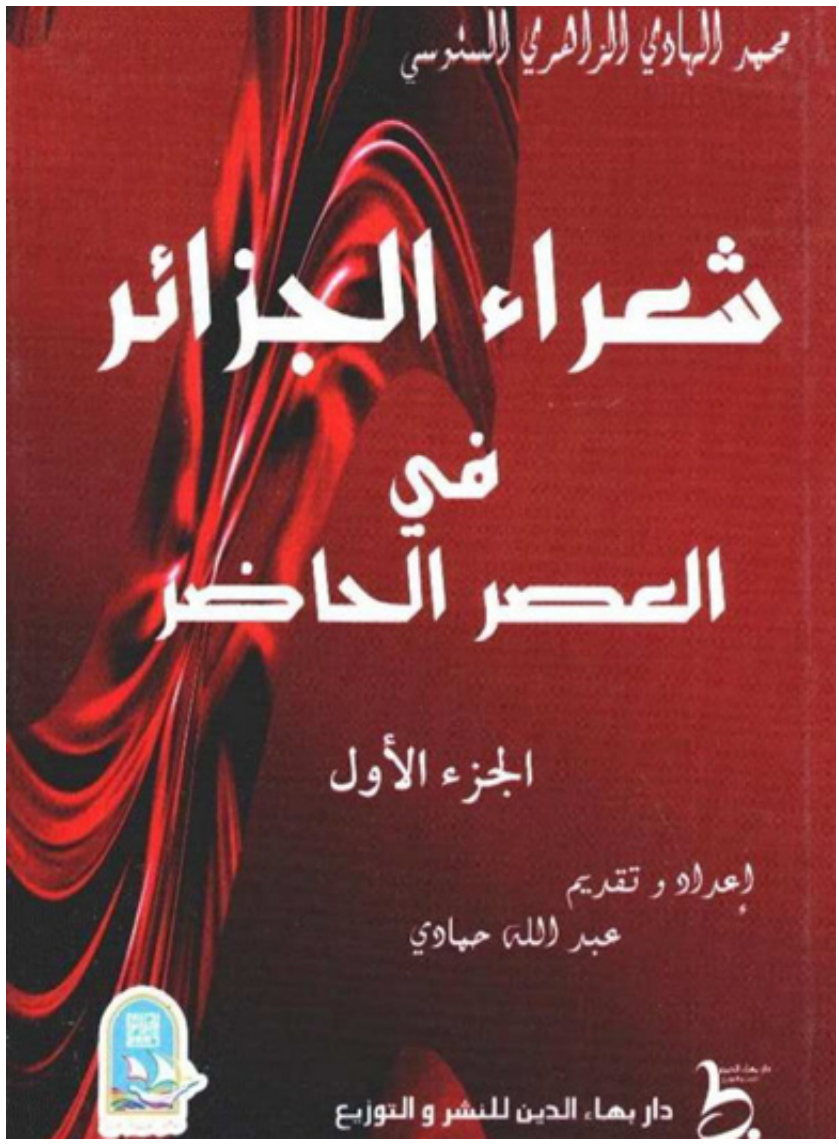



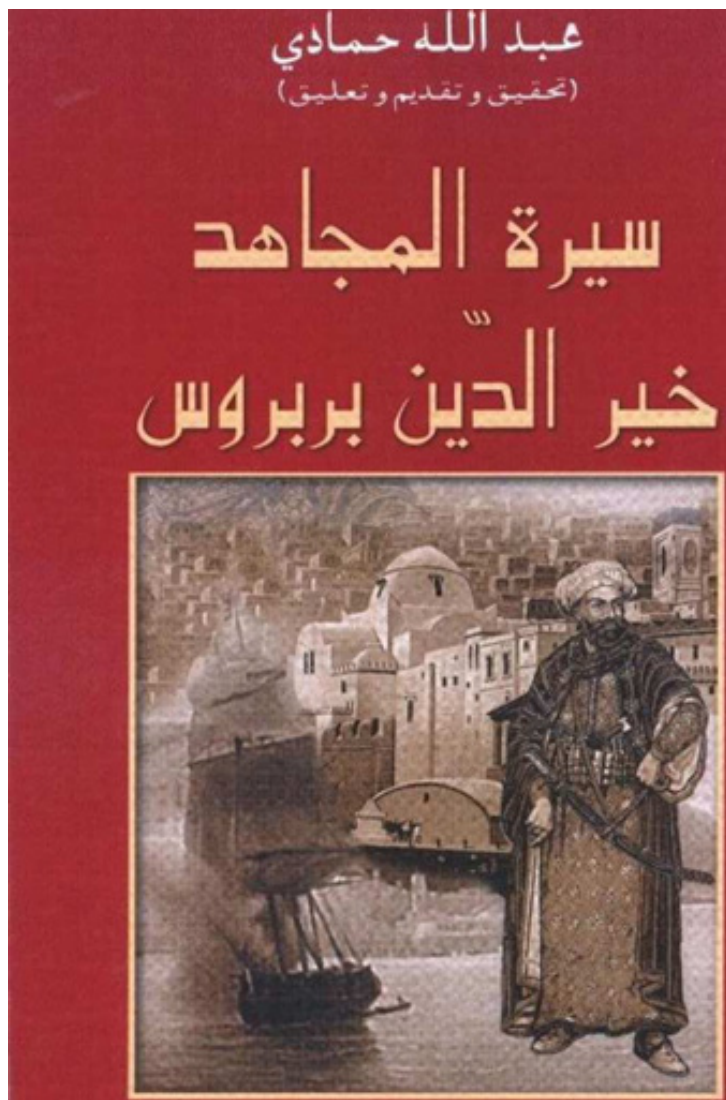


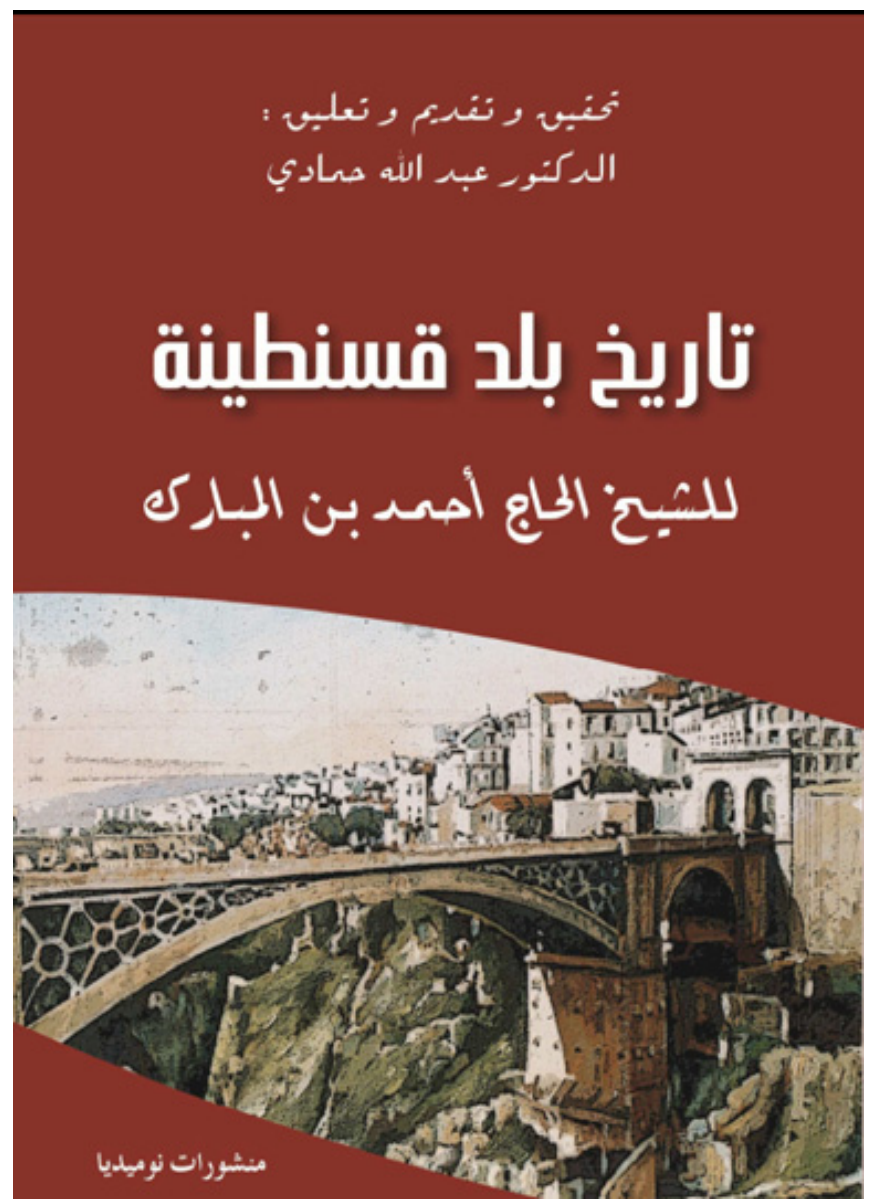




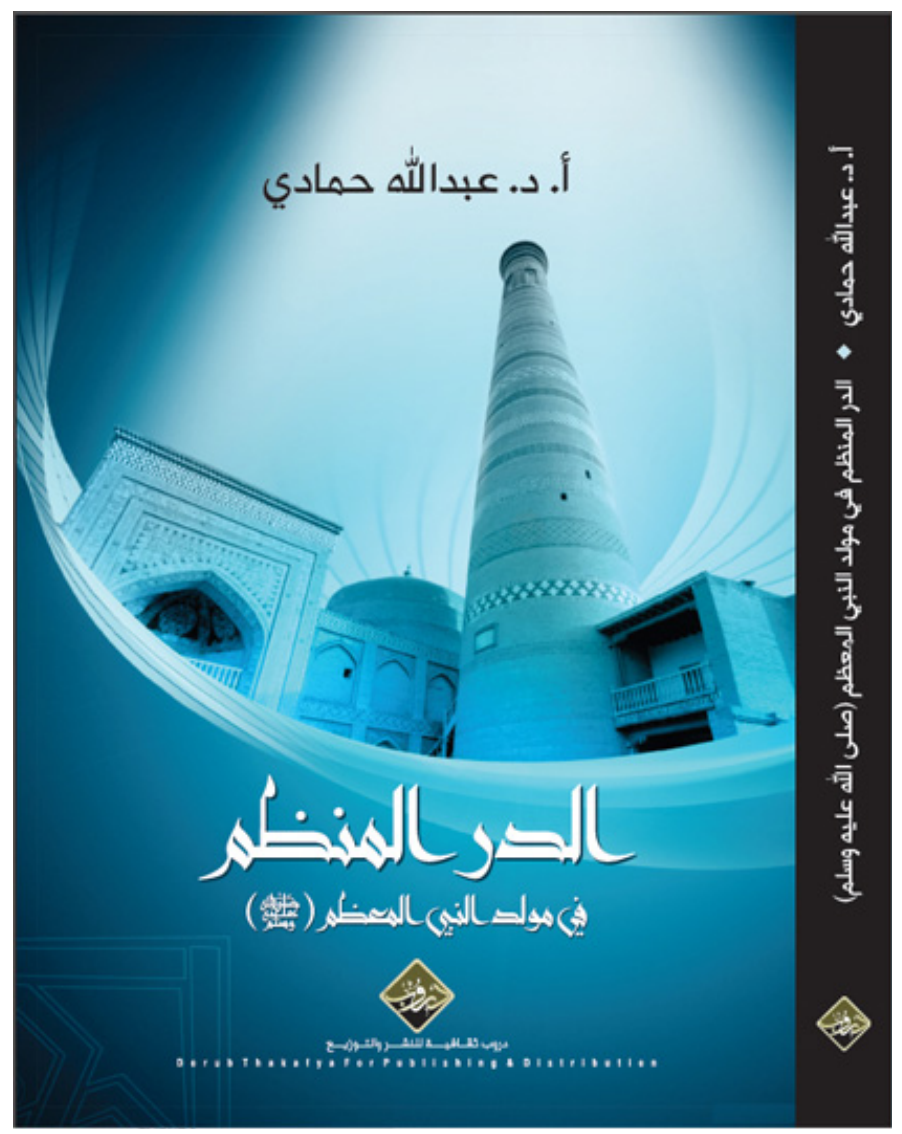





\title{
ABDALLAH HAMMADI EN ESPAÑA: POEMAS DE JUVENTUD
}

\author{
JuAn Martos Quesada \\ Universidad Complutense de Madrid
}

En la actualidad, el escritor y profesor argelino Abdallah Hammadi es un novelista y poeta internacionalmente reconocido y uno de los más famosos representantes de la poesía de expresión en lengua árabe de su país, tal y como lo demuestran los honores con los que ha sido recibido, precisamente en la primavera de este año de 2016, en el Salón del Libro de París, en donde se ha podido asistir, junto a otros poetas árabes de relevancia, a la lectura de parte de sus poemas más representativos.

Como él mismo ha reconocido en varias ocasiones, los años que pasó en España en su juventud, como becario del gobierno argelino y, posteriormente, del Instituto Hispano-Arabe de Cultura para la realización de su tesis doctoral, fueron muy importantes para la evolución de su poesía, al incorporar a su conocimiento y dominio de la poesía árabe clásica la influencia de poetas de lengua castellana como Antonio Machado, García Lorca, Vicente Aleixandre o Pablo Neruda.

Nacido en la ciudad argelina de Constantina en 1947, durante la ocupación francesa, el inicio de la guerra de Liberación obligó a su familia a marcharse a Túnez, al igual que otros compatriotas suyos, a causa de la represora política antiárabe que llevó a cabo la potencia colonizadora; en este país realiza sus estudios de Primaria, para volver a su ciudad natal en 1962, año de la independencia de Argelia, en donde continuará con sus estudios de Secundaria, inmerso el país en el proceso de arabización que los nuevos gobernantes ponen en funcionamiento en 
los años siguientes ${ }^{1}$. Tras la obtención de su licenciatura en Letras en la Universidad de Constantina, comienza a trabajar como profesor en la misma, aunque al siguiente año inicia su estancia en España, en donde viene en el año 1973 y en donde permanece hasta la lectura de su Tesis doctoral, en el año 1980, viviendo a caballo, principalmente, entre las ciudades de $\mathrm{Ma}-$ drid y Granada, ciudad en la que trabé amistad con el escritor.

Cuando llegó a España, ya era un joven poeta publicado en su país, pues sus versos habían visto la luz en periódicos, como al-Nașr de Constantina, o en revistas especializadas de la ciudad de Argel como al-Muŷābid o al-Ša'b al-taqāfì , e incluso contaba ya con un nutrido diván de poesía en lengua árabe, aún inédito en aquella época titulado Tornado del norte sobre el sur (A'âšir al-šamāl 'alà al-ŷanüb), tal y como se recoge en el artículo de S. Fanjul'2.

$\mathrm{Su}$ contacto y afición a la poesía árabe clásica fueron muy tempranos, casi desde su niñez, pues como él mismo nos relata en el Preámbulo de su tesis doctoral:

Casi diariamente, mi padre solía darme dos o tres versos que yo aprendía de memoria a cambio de algunos céntimos para caramelos; con este dulce método fui acumulando cada vez más versos y asociando sus rítmicos sonidos con algo delicioso. Pasaron los años y en mi mente fueron grabándose estrofas y "casidas" por centenares hasta llegar a la adolescencia ${ }^{3}$.

${ }^{1}$ Acerca de este tema, véase el interesante artículo de Montserrat Benítez Fernández, "Un repaso a la política lingüística del Norte de África desde la descolonización”, en Anaquel de Estudios Árabes, 2002, núm. XXIII, pp. 6981.

${ }^{2}$ Serafín Fanjul, "Un poeta argelino en España: 'Abdallah Hammadi”, en Almenara, 1975, núms. VII-VIII, pp. 313-324.

${ }^{3}$ Editada posteriormente por la Fundación Abdul Aziz Saud al-Babtain, que le concedió un premio: Abdallah Hammadi, La poesía en el reino nazarí 
A su llegada a España, a principios de los años setenta del pasado siglo, la literatura árabe contemporánea en general sufría en nuestro país de un casi absoluto desconocimiento, que a duras penas intentaban solucionar los esfuerzos traductores del Instituto Hispano-Árabe de Cultura ${ }^{4}$ y del Departamento de Estudios Árabes e Islámicos de la reciente Universidad Autónoma de Madrid, cuya revista Almenara fue clave en este empe$\tilde{n} o^{5}$. Y si este desconocimiento ocurría con autores de países como Marruecos, Egipto, Iraq o Siria, puede uno imaginarse el tremendo vacío que había en nuestros círculos intelectuales y académicos sobre la poesía actual argelina ${ }^{6}$, más aún si ésta era de expresión en lengua árabe, pues la llevada a cabo por autores argelinos en lengua francesa, por razones obvias, era no mucho pero más conocida en nuestro país ${ }^{7}$.

de Granada (1232-1492), Kuwait, Fundación Babtain, 2004.

${ }^{4}$ Sobre esta institución y su importancia en la divulgación de la literatura árabe contemporánea en España, véase la obra de Miguel Hernando de Larramendi, Irene González González y Bernabé López García (coords.), El Instituto Hispano-Arabe de Cultura. Orígenes y evolución de la diplomacia pública española hacia el mundo árabe, Madrid, AECID, 2015.

${ }^{5}$ Sobre este empeño, $c f$. la obra de Miguel Hernando de Lerramendi y Luis Miguel Pérez Cañada, La traducción de literatura árabe contemporánea antes y después de Naguib Mabfuz, Cuenca, Universidad de Castilla-La Mancha, 2000.

${ }^{6} \mathrm{El}$ artículo de Luis Miguel Pérez Cañada acerca del caso concreto de la literatura argelina es esclarecedor: "Panorámica de los estudios y traducciones de literatura argelina en español”, en G. Fernández Parrilla, L. M. Pérez Cañada y R. Montoro Carrillo, Panorámica de los estudios y traducciones de la literatura del Magreb en español, Toledo, Escuela de Traductores de Toledo, 1998, pp. 17-26; véase también Nafissa Mouffok, "La traducción y el hispanismo argelino. Situación y perspectivas”, en Index.Comunicación, 2014, vol. 4, núm. 2, pp. 49-59.

${ }^{7}$ Sobre la poesía argelina actual en árabe, véase el artículo del profesor de la Universidad de Alicante Isaac Donoso "Antologías de poesía argelina con- 
El inventario de las publicaciones en España de la obra poética de Abdallah Hammadi traducida al castellano de estos años de juventud podemos cifrarlo en cuatro manifestaciones, pues la elaboración de su tesis doctoral sobre poesía nazarí, a la que dedicaremos asimismo unas líneas, merece una mención aparte:

- Cinco poemas, traducidos por el arabista Serafín Fanjul y publicados en un artículo de la revista Almenara, con una nota preliminar del mismo (véase nota 2); los títulos de estos poemas son "A Machado", “¿Poema al burro?, publicado en árabe por el periódico al-Nașr de Constantina el año anterior, “¿No volverá Neruda?", "Poema”, y "Silencio hondo", sumando entre todos unos trescientos cincuenta versos.

- Al año siguiente, en 1976, el mismo autor, Serafín Fanjul, en la sección "Páginas de poesía” de la revista Almenara ${ }^{8}$, traduce algunos poemas de cinco autores árabes residentes en aquella época en Madrid: de los palestinos AbdelKarim al-Huli y Ramzi Darwisch, del egipcio Ahmad Abdel-Aziz, del libanés Simon el-Deiri y del argelino Abdallah Hammadi. Para nuestro autor, seleccionó un largo poema que, bajo el título "Don Quijote se pone en camino", dedicaba Abdallah Hammadi al poeta español Vicente Aleixandre.

- En julio del año 1979, aparece en Málaga, editado por el autor, un libro -inencontrable hoy en día - que bajo el título Entre sol y arena, recoge en unas sesenta páginas la traducción española de una selección de poesía de Abda-

temporánea en lengua árabe", en Revista Argelina, primavera-verano 2015, núm. 0, pp. 29-40.

8 "Jóvenes poetas árabes en Madrid", en Almenara, 1976, núm. IX, pp. 203-216. 
llah Hammadi, llevada a cabo por él mismo, en donde se agrupan algunos de los poemas ya editados en nuestro país, otros que vieron la luz en lengua árabe y otros inéditos. A este respecto, es pertinente recordar que este mismo año, un equipo de profesores del departamento de Español de la universidad argelina de Orán encabezados por el poeta y premio Adonais Emilio Sola ( Zoubeida Hagani, Mokhtar Abdelwaret y Mohamed Benmebkhout) publica también en Málaga, en la editorial Cuadernos de Afrobética, dirigida por el escritor Francisco López Barrios, la primera antología bilingüe (españolfrancés $)^{9}$ de la poesía argelina contemporánea de expresión francesa, bajo el título País de larga pena. Pequeña antología de la poesía argelina contemporánea (1950-1978), en la que se recogen poemas de escritores del país vecino de tres generaciones. En la nota de presentación de este libro en el boletín Arabismo, se hace mención a una futura continuación, con la publicación de otra antología bilingüe (árabe-español) de poetas argelinos de expresión árabe a cargo del profesor Marcelino Villegas, continuación que, lamentablemente, nunca vio la luz y en la que, con toda probabilidad, hubiera estado presente Abdallah Hammadi.

- Por último, el profesor y arabista Pedro Martínez Montávez, en el año 1994, en un número monográfico sobre la producción poética árabe actual de la revista Arrecife de Murcia ${ }^{10}$, titulado Tiempo de poesía árabe, traduce un breve

${ }^{9}$ Véase el boletín informativo del Instituto Hispano-Árabe de Cultura Arabismo, enero-marzo 1980, núm. XXVII, que recoge la noticia en su página 7; véase también Isaac Donoso, op. cit., p. 16.

${ }^{10}$ Pedro Martínez Montávez, “Tiempo de poesía árabe”, en Arrecife, XXXIII-XXXIV (1994). 
poema de nueve versos de Abdallah Hammadi bajo el título "La palabra avergonzada", escrito durante su estancia en España.

La lectura y análisis de estos poemas tempranos de juventud nos hace llegar a una serie de conclusiones acerca de las principales características de esta primera poética de Abdallah Hammadi.

En primer lugar, es obligado y primordial destacar que la característica fundamental, y de algún modo esencial y que recorre transversalmente toda la actividad del poeta, es su indudable conocimiento y dominio de la poesía clásica árabe, de sus reglas y de sus principales rasgos; es, sin duda, el entramado, la base y los cimientos de toda su producción poética, que penetra en todos sus poemas y se muestra de manera orgullosa en todos sus versos, sea cual sea la forma o el tema elegido. Y este dominio de la estructura de la poesía clásica árabe no sólo le viene por el estudio de la misma y el conocimiento exhaustivo de sus principales autores, fruto de una formación literaria tradicional, sino también $-\mathrm{y}$, desde mi personal punto de vista - por la memorización de centenares de poemas clásicos que ha hecho que el ritmo y la métrica tradicionales árabes se hayan instalado de forma permanente en su mente y su expresión se haga como una cosa natural.

En segundo lugar, su estilo es, como afirma Serafín Fanjul, fruto de un esfuerzo personal e individual, que intenta esquivar su encasillamiento en una determinada escuela o tendencia, lo que le lleva a trabajar concienzudamente la elaboración de un poema, en un estilo un tanto rebuscado y enrevesado, con un uso prolijo de figuras literarias, retóricas y poéticas, más en el camino de una concepción clásica de la poesía que de una orientación más moderna y libre. Figuras como el hipérbaton, la 
alegoría, las comparaciones, las interrogaciones retóricas, las metáforas o las metonimias son habituales en sus creaciones.

En tercer lugar, es de destacar el enorme cuidado que tiene en la búsqueda del término exacto que exprese su sentimiento, lo que le hace trabajar un léxico rico y abundante, fruto también, cómo no, de su influencia de la poesía clásica árabe. La adjetivación en todos sus aspectos (epítetos, sinónimos, repeticiones, etc.) es un elemento visible en todos sus poemas, tanto en los escritos en lengua árabe como en la traducción de los mismos al español, lo que sin duda habrá supuesto un esfuerzo añadido a sus traductores.

En cuarto lugar, es necesario hablar de su temática, de sus temas favoritos, más inclinados a la reflexión y a la expresión de sentimientos humanos, como el amor, la soledad, el silencio, la contemplación o la reflexión íntima, que a temas de corte realista o de poesía social (sin que por ello, se niegue a tratar estos temas cuando es necesario hacerlo, en particular cuando la visión de esta realidad nos lleva al desaliento o a la desesperanza); no es, desde luego, un poeta al que se pueda clasificar de social y quizás por ello, Martínez Montávez no lo incluyó en su antología de la poesía árabe realista contemporánea ${ }^{11}$.

Por último, hemos reservado para el quinto lugar una característica sin duda fruto de su contacto con la lengua y la poesía en castellano, tanto española como hispanoamericana, como es la influencia de lo español y de los poetas de lengua castellana en su obra. Las influencias de Pablo Neruda, Antonio Machado, Vicente Aleixandre, Rafael Alberti, Federico García Lorca, Miguel Hernández o de los poetas andaluces de su tiempo, que tan bien conoció y leyó, son visibles en su quehacer poético, a lo que hay que añadir una sensibilidad especial por cantar temas de la cultura española, como Don Quijote o la Alhambra, o

${ }^{11}$ Pedro Martínez Montávez, Poetas realistas árabes, Madrid, Rialp, 1970. 
rendir homenaje a sus escritores favoritos dedicándole poemas muy personales, como los dedicados a Neruda o a Machado.

Como ya hemos dicho, creemos pertinente traer a colación el trabajo de investigación llevado a cabo en España, en estos años de juventud, por Abdallah Hammadi sobre la poesía nazarí y que fue fruto de su tesis doctoral, dada la importancia que tuvo para el conocimiento de la cultura del reino musulmán de Granada y, en particular, para el estudio de la literatura nazarí, campo no suficientemente analizado ni traducido en esa época ${ }^{12}$. La tesis doctoral, con el título La poesía en el Reino Nazari de Granada (1232-1492) y dirigida por la profesora M. J Jesús Rubiera Mata, fue leída el día 16 de junio de 1980 en el Departamento de Árabe e Islam de la Universidad Complutense de Madrid, siendo publicada posteriormente en Kuwait, en el año 2004, por la Fundación Abdul Aziz Saud al-Babtain.

Con un manejo exhaustivo de las fuentes conocidas y con el añadido de, al menos tres manuscritos nuevos sobre el tema descubiertos por el autor, la tesis se divide en diez capítulos, en donde se analiza la producción poética de los escritores granadinos de esta etapa final de al-Andalus, a través del estudio de los diversos temas presentes en sus poemas. En el capítulo I se trata el panegírico y las diferencias de éste con el oriental; el capítulo II está dedicado a la poesía como arma para llevar a cabo súplicas o controversias; en el III se nos habla de la sátira como tema poético, confrontando su escasez en Granada con la abundancia de este género en Oriente; el capítulo IV está dedicado al tema del amor y sus múltiples variantes; el capítulo $V$ trata del libertinaje (al-muŷūn), entendido como el canto a los placeres que nos ofrece la vida; el VI nos presenta la vida devota, la poesía religiosa, en sus manifestaciones mística, ascética o

${ }^{12}$ Para una panorámica de los estudios sobre este tema, véase Celia del Moral, "La literatura del periodo nazarí", en Concepción Castillo Castillo (ed.), Estudios nazaries, Granada, Universidad de Granada, 1997, pp. 29-72. 
sapiencial; el siguiente capítulo, el VII, está dedicado a los temas festivos, tanto religiosos como profanos; el capítulo VIII se refiere a los trenos, a los lamentos fúnebres, género poético en donde se analizan las diferentes modalidades existentes según la relevancia social del finado; el capítulo IX, quizás el más abigarrado de todos, contempla temáticas variadas como las correspondencias (al-ijwāniyāt), la patria o el paisaje; y, por último, en el capítulo X, Abdallah Hammadi reflexiona sobre las características de esta poesía nazarí, en particular su acusado conservadurismo. No cabe duda que este estudio y traducción de los poetas nazaríes de al-Andalus a través de su temática ha marcado un hito en el conocimiento de este capítulo de la poesía clásica árabe de occidente.

$\mathrm{Y}$, finalmente, como complemento a estos apuntes sobre la poesía de juventud de Abdallah Hammadi, creemos oportuno hacer mención, aunque sea de forma breve, a su actividad como traductor y estudioso de la literatura española e hispanoamericana. Como hispanista reconocido en el mundo árabe, nuestro autor ha llevado a cabo, desde mediados de los años setenta del pasado siglo, un buen número de traducciones al árabe y de estudios de la poesía en lengua castellana. Labor nada fácil y que necesita la sensibilidad de un poeta para acometerla, además de un excelente conocimiento de las dos lenguas, árabe y español. Las reflexiones a las que le ha llevado esta experiencia traductoria las ha expresado de forma precisa y sincera Abdallah Hammadi en una intervención durante las Jornadas de Hispanismo Árabe que tuvieron lugar en Madrid a finales de mayo de $1988 .^{13}$

${ }^{13}$ Abdallah Hammadi, "La traducción literaria a través de mi modesta experiencia” (en lengua árabe), en Fernando de Ágreda Burillo (ed.), La traducción y la crítica literaria. Actas de las Jornadas de Hispanismo Arabe. Madrid, 24-27 de mayo de 1988, Madrid, Agencia Española de Cooperación Internacional (AECID), 1990, pp. 465-470. 
Su actividad y su afán por dar a conocer la literatura en lengua española al mundo árabe a través de su traducción la comenzó en la revista iraquí al-Aqlām, en donde, a lo largo de los años 1975 y 1976 tradujo poemas de Vicente Aleixandre y Pablo Neruda ${ }^{14}$. Esta labor de traducción y publicación en revistas y periódicos le ha acompañado a lo largo de su vida aunque, por citar algunas de sus obras más importantes, destacaremos dos libros que estimamos relevantes en este campo de su actividad académica por la fama que llegaron a alcanzar en Argelia. Nos referimos a la introducción que hizo para el estudio y conocimiento de la poesía española contemporánea, con una amplia antología de la misma, publicada en su país a mediados de los años ochenta ${ }^{15}$ y a la selección de poetas y poesía andaluza contemporánea que llevó a cabo a principios de este siglo, fruto de sus contactos y conversaciones con escritores de esta tierra española respecto a la influencia de la presencia árabe en España ${ }^{16}$.

Finalmente, de entre su nutrida labor como hispanista, traeremos a colación también dos de sus obras - aparte de la ya mencionada introducción a la poesía actual española-, las dedicadas al estudio y análisis de la obra de dos grandes autores sudamericanos, Pablo Neruda y Gabriel García Márquez dadas a conocer en los años ochenta y publicadas respectivamente en Túnez y Argelia ${ }^{17}$.

${ }^{14}$ Abdallah Hammadi, "Diez poemas de Vicente Aleixandre" (en lengua árabe), en al-Aqlām, Iraq, 1975, vol. 2, pp. 13-17; "Poemas de Pablo Neruda" (en lengua árabe), en al-Aqlām, Iraq, 1976, vol. 10, pp. 21-28.

15 Abdallah Hammadi, Introducción a la poesía española contemporánea (en lengua árabe), Argel, ENAL, 1985, 320 páginas.

${ }^{16}$ Abdallah Hammadi, Al-Andalus, entre el sueño y la realidad (conversaciones con poetas andaluces) (en lengua árabe), Constantina, Universidad de Constantina, 2004.

17 Abdallah Hammadi, Aproximación al poeta Pablo Neruda (en lengua árabe), Túnez-Argel, coeditado por la SNED de Argelia y la MTED de Túnez, 1985; Gabriel García Márquez: pionero del realismo mágico (en lengua 


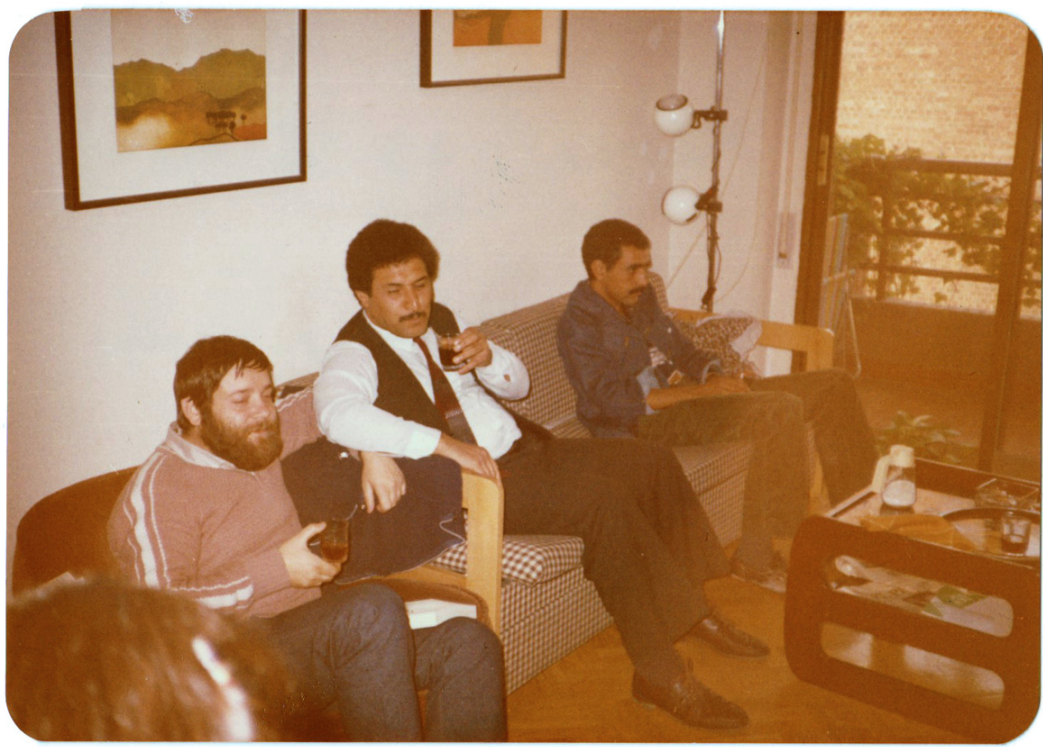

Abdallah Hammadi, su hermano y el autor de este texto en su casa de Madrid

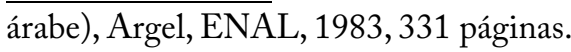





\title{
بناء الصورة في شعر عبد الله حمادي \\ LA CONSTRUCCIÓN DE LA IMAGEN EN LA POESÍA DE ABDALLAH HAMMADI
}

\author{
أحمد بقار \\ جامعة قاصدي مرباح ورقلة - الجزائر \\ AHMAD BAGAR \\ Universidad Kasdi Marbah-Wargla
}

\section{Resumen:}

Abdallah Hammadi está considerado como uno de los poetas que participaron en el desarrollo del contenido poético aparte de su trabajo y su producción como académico. A lo largo de su carrera poética ha compuesto cuatro divanes poéticos: Emigración a las ciudades del sur, Ob Leila, la pasión sobreviene, Poemas gitanos y Umbral y cuchillo.

En este artículo se analiza la estructura de la imagen poética en los dos primeros divanes, cuya poética imita las formas tradicionales, mientras que en los dos siguientes introduce innovaciones de manera progresiva. También se destaca que la imagen se construye de las formas siguientes: la imagen simple (parcial), a través del intercambio figurado, de la correspondencia del significado y a través de la comparación y la descripción directa.

Palabras clave: Abdallah Hammadi, imagen poética, intercambio figurado, correspondencia del significado, crítica literaria.

\section{ملخص:}

يعد عبد الله حمادي من الشعراء الجزائريين الذين قفزوا بالشعر من ناحية المضمون،

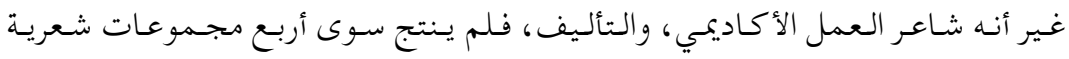

( الهجرة إلى مدن الجنوب، تحزب العشق يا ليلى، قصائد غجرية، البرزخ و السكين ) . 
ويتناول هـذا المقال بـناء الصورة الشعريـة في هـذه البمسوعات، حيـث ألفيناه مقلدا في

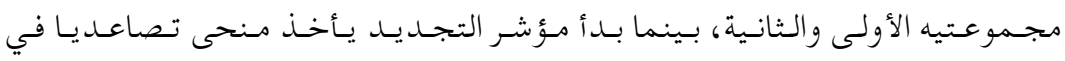
المجموعتين الثالثة والرابعة، ولقد وجدنا الصورة عنده تبنى وفق الأشكال التالية: الصورة المفردة ( الجزئية )، بناء الصورة عن طريق تبادل المدر كات، عن طريق تراسل الحواس وعن طريق التشبيه والوصف المباشر. مـفاتيـح البحثث : عسبدلله حسمادي؛ الصصورة الـشعريـة؛ تـبادل المـدركـات؛ تراسل

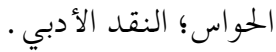

تعتبر الصورة الشعرية من أبرز الوسائل الشعريـة التي وظفها حمادي في نقل تجربته الشعريـة "فبها تتجسـد الأحاسيس وتشخص الخو اطر والأفكار، وتتكشف رؤيته الخاصة عن العلاقات الخفية والحقيقة في عالمه، وهي أيضا وسيلته في معرفة النفس وأقاليمها الغامضة، وارتباطها بـأشياء العالم "1، لقد نشأت أهمية الصورة الشعريـة ( الفنية ) مـن خلال معركة النقاد والبلاغيين في الـفصل بــن الـلفظ والمعنى، فـالـلفظ هـو الصـياغـة الـشكلية والهـيكل التركيبي في العمل الأدبي، والمعنى هو الفكرة المجردة التي تفي بـالغرض، ولقد أحسدث هـذا الفصل تقسيما بـيِّا في النص الأدبي وجعله ذا دلالاتين أولاهـما خـارجـية تـتصل بـالشكل والأخـرى داخـلية تـقترن بـالمضمون، ثـم تفرقت النظريات وتضاربـت الآراء، فمنهم من ناصر اللفظ، ومنهـم من انتصر للمعنىى، ذهب عبد القاهر الجرجاني إلى علاقة التكامل والتداخل مل بينهما، غير أنه يـلمح إلى أن المعاني لها الأسـبقية في النفس عـلى ألفاظها قائـلا:

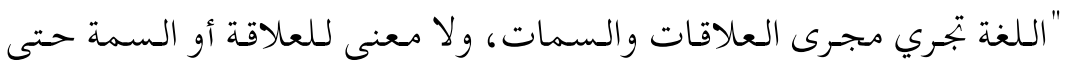




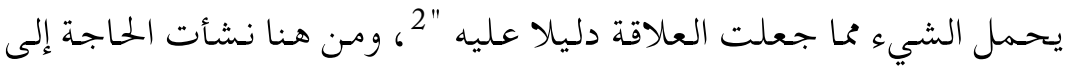
الصورة الفنية بـاعتبارهـا أداة لها طريـقتها الخـاصـة في عرض المعاني مقترنـة بـالألفاظ لِيتفاعل المتلقي بـالنص، ومـن ثم يكتسـب العمل الأدبي مـناخـا يشعرنا بالتئام اللغة والفكر في إطار موحد مما يجعلنا نسير وراء الصورة في استكناه العلاقات القائمة بين اللفظ والمعنى أو الشكل والمضمون، ويكون طريق كشف هذه العلاقات في استنباط المعاني من سبيل صياغتها المتمثلة في التشبيه والاستعارة والتمثيل والمجاز . والشعر الذي يعتمد على الصورة هو غوص وإضلاءة لجوهر الوجود "فليس هو فراغـا يمـالأ بـألفاظ، وإنما هو مسشاعر وأحساسيس وحسياة صاخبة فيها قوة مـثيرة" 3، والصورة بمـنظورهـا الأدبي هي : الصوغ الـلساني الخخصوص الـذي بوساطته يتجري تمثل المعاني تمثلا جهديدا ومبتكرا بما يحيلها إلى صور مرئية

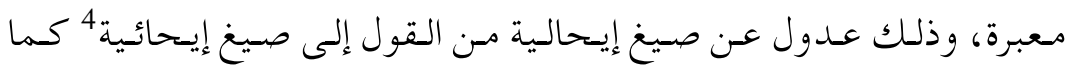
"تسـتعمل كـلمة الصورة -عـادة- لـلدلالـة عـلى كـل مـا لـه صـلة بـالـتعبير الحسي، وتُطلق أحسيانـا مـرادفة للاستعمال الاستعاري للكلمات "5 ، وبهـــا يبدو لنا أن التصوير في الأدب يأتي نتيجة لتعاون كل الحواس ... والشاعر المصور حين يربط بين الأشياء يثير العواطف الأخلاقية والمعاني الفكرية، وفي الإِدراك الاستعاري خـاصسية تـتبلور العاطفة الأخـلاقية وتتحـدد تحـددا تـابعا لمبيعته 6.

إن الصورة الـشعريـة الحـلديـة لـها فـلسفة جـمالية مـتختلفة فـأبرز مـا فيها ( الحسيويـة )؛ وذلك مرده إلى أنها تـتشكل تششكلا عضويـا، وليست مجـرد حشد مرصوص من العناصر الجامدة، فقد أصبحت أداة تعبيرية تعبر بالصور 
الكامـلة عن المعاني، كما كان الشاعر سابقا يعبر باللفظة، وكما كانت اللفظة أداة تعبيريـة، بـحيث تحولـت الصورة في ذاتها أداة للتعبير، وبهـذا يصبح من الصعب، فصل الصورة عن اللغة. ولا يخفى من خلال ما تقدم أن الصورة الشعرية ذات تأثير كبير وفعال في وجـدان المتلقي؛ لأنها تنقل تفاعلات المبدع وتنصهر كلها في تشكيل

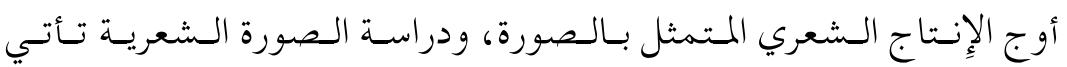

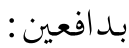

الأول : أن الصصورة تعبير عـن نفسـية الشاعر؛ وأنها تشـبه الصور الـتي تتراءى في الأحلام.

الثاني : أن دراسة الصورة مجتمعة قد تعين على كشف معانٍ أعمق من المعاني الظاهرية للقصيدة؛ ذلك لأن الصورة وهي جميع الأشكال المجازية؛ إنما تكون من عمل القوة الخالقة، فالاتجاه إلى دراستها يعني الاتجاه إلى روح الشعر ولمصورة الشعرية عدة مصادر:

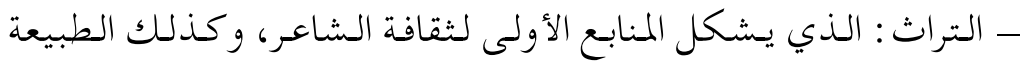
بكل ما تنطوي عليه من أشياء دقيقة أو جليلة. - الخيال : وهو قوة منشئة مبدعة تقلب نواميس الواقع والطبيعة، وتهبها تسائا قوانين خاصة، وتستنهض ثقافة المبلدع وتقوم باسترجاع الحالة الشعورية التي عايشها في تجربته . والخـيال تـعريـفه عسـير؛ لأنه مـصطلح يـوظـف في أنسواع مـختلفة مـن 
العمليات العقلية، وهو مـلكة غامضة لا يمكن تعريفها إنما يمكن معرفتها بأثرها 8

تعتبر الصورة الشعرية من أبرز الوسائل الشعريـة التي يوظفها الشاعر

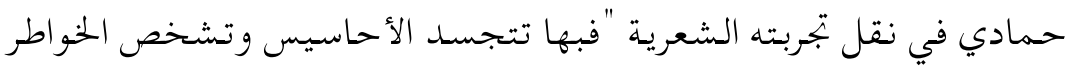
والأفكار، وتنكشف رؤيته الخاصة عن العلاقات الخفية والحقيقة في عالمه، وهي أيضا وسيلة في معرفة النفس وأقاليمها الغامضة، وارتباطها بـأشياء

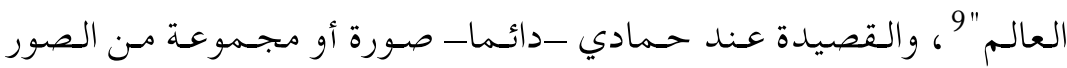
الجزئية المتآزرة والمتفاعلة، فهو عندما يصور ذوبان الجمال يقول:

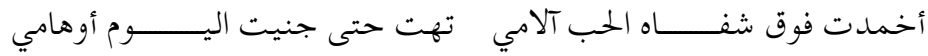

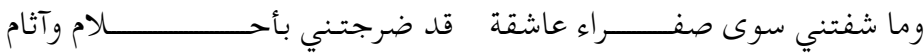

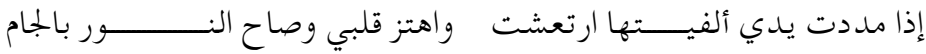

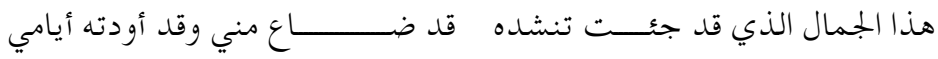

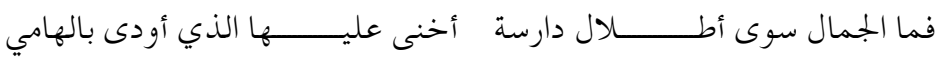

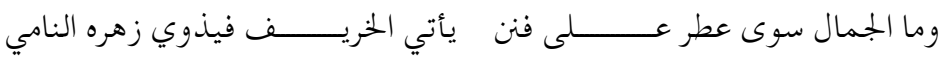

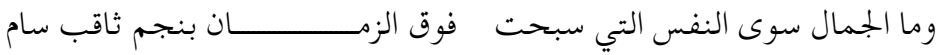

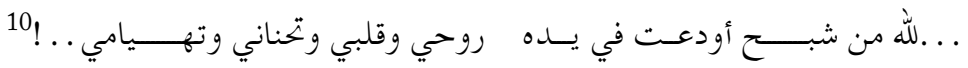
فالمتأمل في الأبيات الثمانية يجدها مكتظة بالصور الجزئية، وهي أبيات من قصيدة يتعذر الوقوف فيها على صور غير مجازية، وفي هذا الحيز من القصيدة نجد التعابير ( شفاه الحب، جنيت أوهامي، ضرجتني بأحلام، صلح

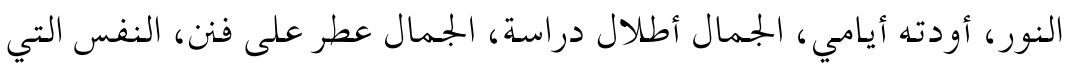

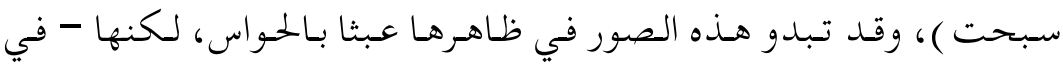


الحقيقة- لغة طبيعية لتصوير الشعور العميق لدى الشاعر بالغرابة من انتهاء

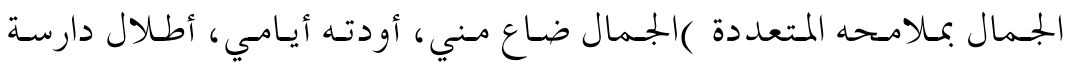
يذذوي زهره ) . وفي الأخير ( الجمال شبح) )، وماذا يعقب ذلك غير الخراب،

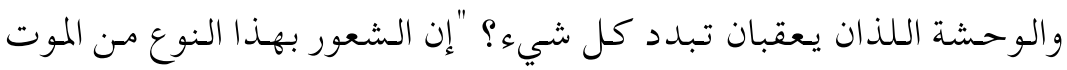

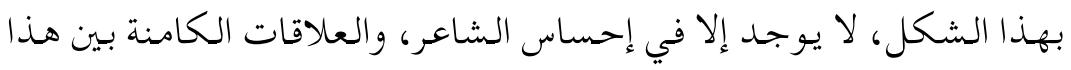

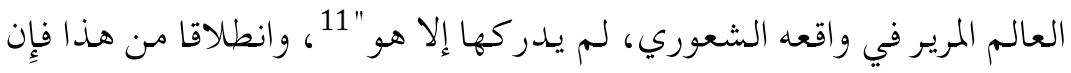

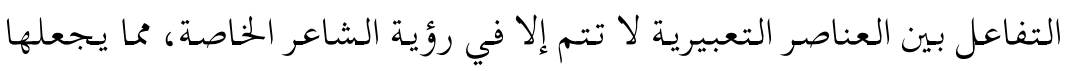

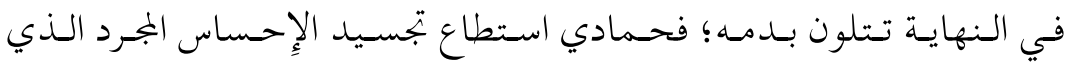
يعانيه في مشهد غني بالحس زاخر بالحركة والحياة. ومن خلال الوقوف على المجموعات الشعرية وجدنا أن الصورة الشعرية

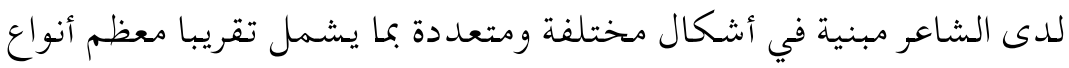
الصورة الشعرية وأشكالها:

\section{1 - أنواع الصورة الشعرية و دلالاتها في شعر حمادي: 1 - 1 - الصورة المفردة ( الجزئية ):}

وهي تعد أبسط الصور الشعريـة ومككونات التصوير الشعري من حيث أشيث

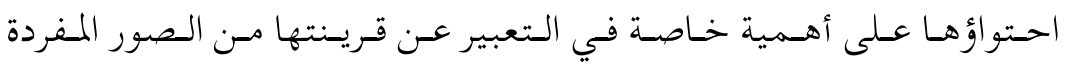

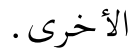

$$
1 \text { - } 2 \text { - بناء الصورة عن طريق تبادل المدركات : }
$$

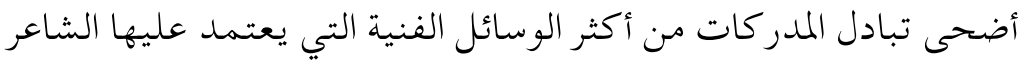

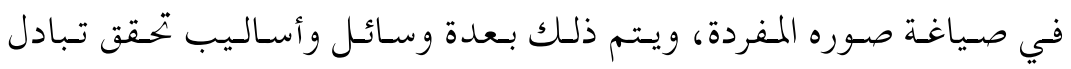


المدركات، وعلى رأسها "التجسيد الذي يتم بخلع صفات محسوسة على المعنويات"12، يقول في (إيقاعات عربية ):

فالشعر جاشـت قوافيه الذي درجت منذ الطفــــــولة عن دمع وأنّـــــــات

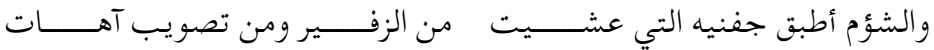

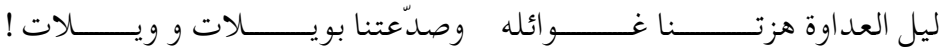

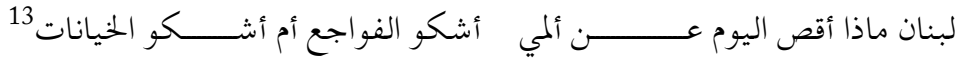
هذه المقطوعات من قصيدة ( إيقاعات عربية ) في (1973م) التي نظمها

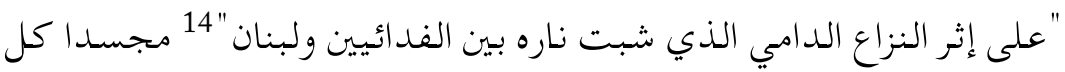
آلام العروبة وما تعانيه من انقسامات، وقدل توحسد الكلمة ـ وبهـذه الصور جســ الشاعر صفات مـاديـة، ف ( القوافي تجـيش بـالبكاء، والشؤم يطبق جفنيه، والغوائل تهز )؛ إن الصور هنا بالغة الدقة توازي حجم التغير الذي آلت إليه الأمة، فالقوافي تبكي، والشؤم له أجفان يطبقها، والغو ائل لها قوة

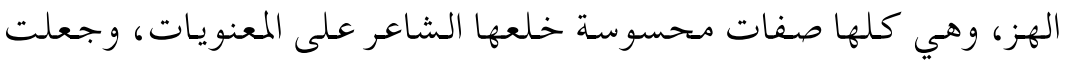
النص يخرج من المباشرة المتداولة والمستهلكة.

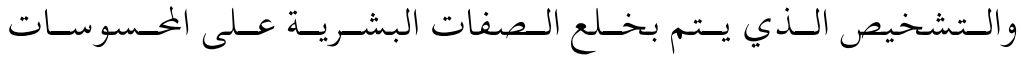
والمعنويات من تبادل المدر كات، ومن أمثلة ذلك، في (قصيدة الجزائر ):

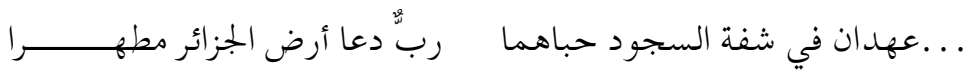

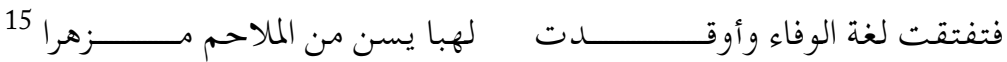

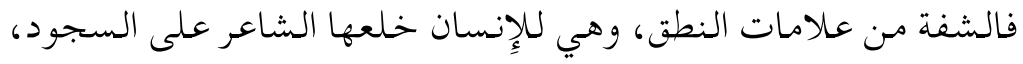
وقد صور الجزائر بأروع الصور، صور الجمال التي يدعو إلى السجود توحيدا 
للحخالق العظيم، وصسور الجـلال الـتي يـدعو إلى الإِكبار والوقوف احترامـا

$$
\begin{aligned}
& \text { لتاريخها المجيد . } \\
& \text { من صور التشخيص قوله في (قصيد !): } \\
& \text { فهل يكفي العزاء !؟ } \\
& \text { يا جماعة العزاء ! } \\
& \text { وتلد الهزيمة في قبركم هزيمه } \\
& \text { يرجع الكـلام لخبس الكلام } \\
& \text { وتنتهي القضية والعالم بكاء } \\
& \text { والعالم دماء. و والعالم بخير ( ... 16 }
\end{aligned}
$$

يبدو الشاعر في هذا المقطع متألما أشد ما يكون التألم والتوجع؛ فالهزيمة

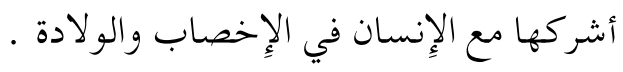

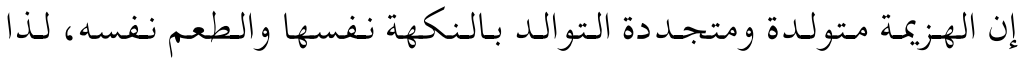
جعلها بصيغة الإفراد؛ لأنها واحـدة، وإن اختلف الزمن، فنسبة الولادة إلى أشياء معنوية يحقق بناء صورة شعرية تقترب من ( الإِيحاء) و( اللامباشرة ) في أوج التعبير عن المكنونات الفكرية المصورة بلغة أدبية . أما الأسلوب الآخر لتبادل المدركات الذي يساهـم في بناء الصورة الجزئية ( المفردة ) فهو ( التجريـد )؛ الذي تكتسب فيه الماديات صفات معنويـة و"

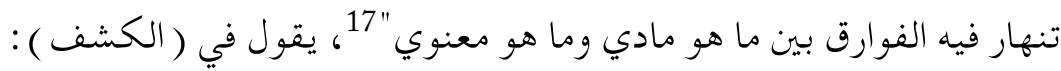

$$
\text { تفضت يدي فاستراح الغبار }
$$




$$
\text { سافر حلمي ( . (... ) ومدّ شعار } 18
$$

نـقرأ ( اسـتراح الـغبار، تسـلقت كـل شـعاب الحـلديـث، سـافر حـلمي )، فالغبار لا يستريح، والحمديث ليس له شعاب ولا يمكن تسلقه، كما أن الحلم لا يسافر

$$
\text { يقول في ( مذكرة مخرومة لأبي محجن ) : }
$$

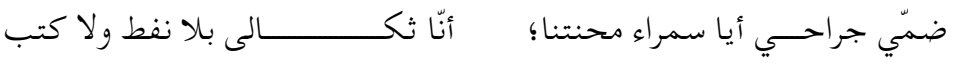

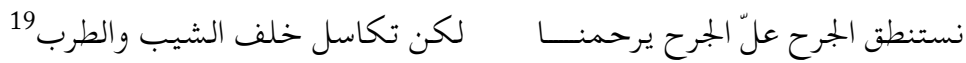

ويظهر التجريد في قوله (عل الجرح يرحمنا ) حيث خلع على الجرح وهو الشيء المادي صفة دعنوية وهي الرحمة . ويقول في ( تباعدات جلال الدين الرومي ):

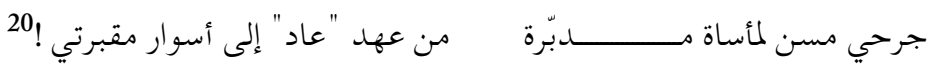

فالجرح لا يسن، وجمال الصورة يبدو في عمق الجرح وغوره، فهو يضرب مسنذ القدم، فالصور تعكس تجربـة الشاعر الخـارجية، وتستبطن الانفعالات النفسية والشعورية الداخلية، وهذا ما يؤ كد عليه ( نوفاليس ) فالشعر عنده "تصويـر الكنه النفسي، كما هي تصويـر العالم الـاخـلي بـكليته، هـذا مـا توضسحه الككلمات الـتي هي واسطته، إن الككلمات هي بـالـتأكيد التجـلي الخارجي لهذا العالم الداخلي من القوى" . 21

$$
1 \text { - } 3 \text { بناء الصورة المفردة عن طريق تراسل الحواس : }
$$

يقوم بناء الصورة في هذا النوع من التصوير على وصف مدرك حاسة بما 
توصف مـدركات حاسة أخرى؛ كأن يوصف المرئي بصفات المسموع، أو

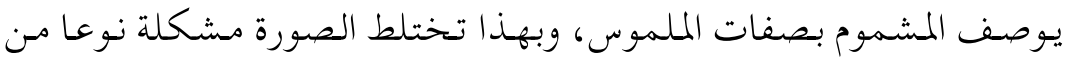

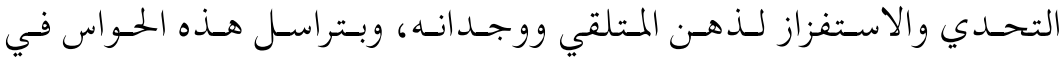
الصورة الشعرية تتوازى بعض العلاقات الطبيعية التي تربط بين عناصر الواقع لتحل محلها علاقات أخرى مردها إلى ذات الشاعر، وقد وظف حمادي هذه الطريقة في بناء الصورة المفردة، يقول في قصيدة ( قراءة في كتاب الإِنسان

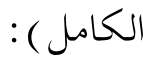

تساق إليه أكــــــــف العــــــــام،

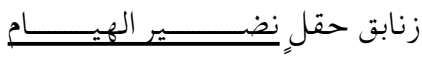

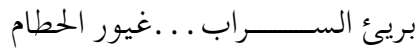

ولا ابتعســت من طريقي الأمامي 22

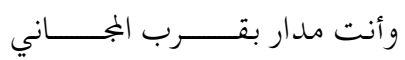

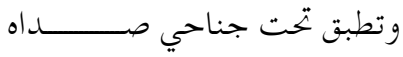

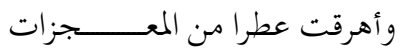

فلا نطقت من جنــاحي الجراح

تراسل الحواس في هذا المقطع يكمن في مايلي:

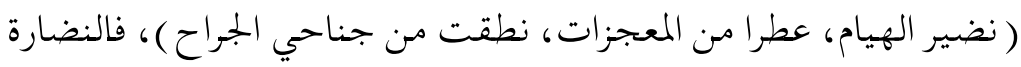

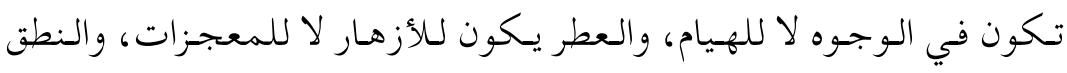
يكون للسان لا للجراح، ولكي يضفي الشاعر العذوبة والجمال لهذا الهيام

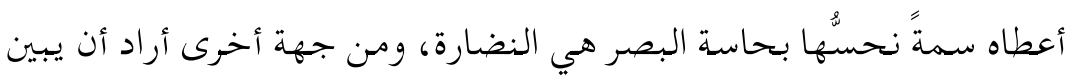
لنا قوة المعجزات أضفى عليها سمة من حاسة الشم ( شم العطور )، وعندما

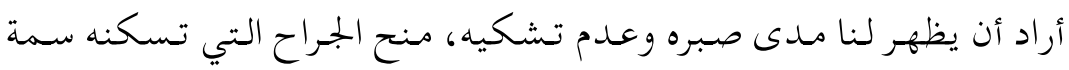

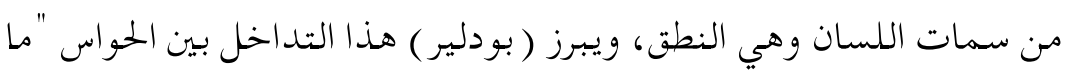
دام المقصود من العمل الشعري أن ينقل أثر التجربة من نفس إلى نفس وما دام بعض المدر كات قادرا على أن ينقل الذاتي لمدرك آخر فِإِن من الطبيعي أن لن 
يستعير الشاعر مـن إحـدى الحهواس مـا يـجعله عـلى معطيات حـاسـة أخرى،

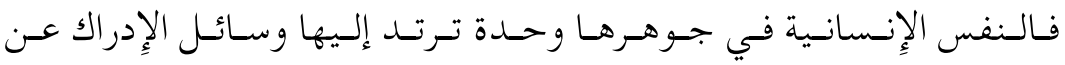

تعلد دها"

1 - 4 بناء الصورة عن طريق التشبيه والوصف المباشر:

وهـو مـن أسهـل الأسـالـيب الفنية الـتي يستـخدمهـا السشاعر في ابـتكار الصورة الشعرية، غير أنه أقل قدرة على الإِيحاء إذا لم يـحسن الشاعر إقامة

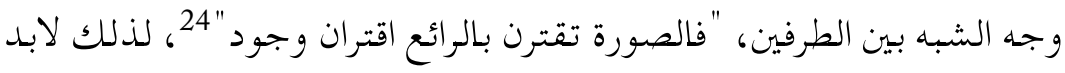
من البحث عن طرفي تشبيه متناسبين، حتى تتحقق الصورة الفنية في أوج جمالها يـقول حسمادي في وصـف قريسة ( سـيدي عبد الـعزيـز ) الجـميلة المحاذيـة

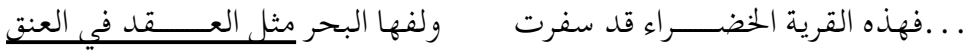

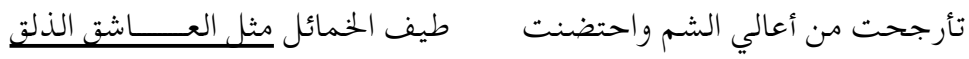

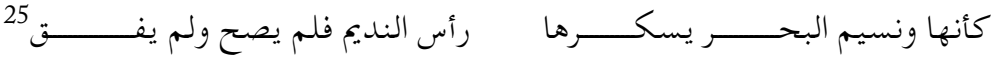
( مثل العقد في العنق، طيف الخمائل، مثثل العاشق الذلق، كأنها رأس النديم )، فالتشبيه مباشر غير أنه يـماز بـكونه غير مكرر عنده، فحمادي لا

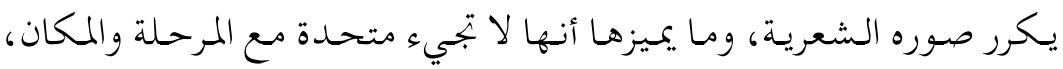
ونـرى الشاعر حمادي منتشـيا بـالحـبـ، فيقول في قصيدة ( خـذ فؤادي ... ولا تسل عن همومي ) :

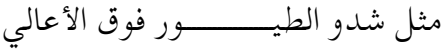

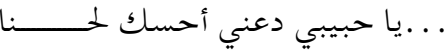




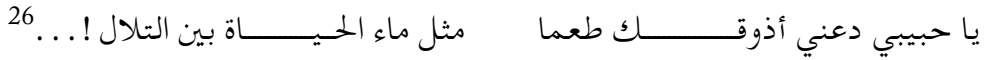

لقد حافظ على الصيغة نفسها غير أن الصورة التشبيهية مختلفة، فمن الطبيعي أن يشبه الحبيبب مرة بـلحن الطير الجميل في الأفق، وأخرى بطعم مـاء بـارد عـذب زلال منحـدرٍ هـن التلال، وكـلاهـما يحـمل في ذاتـه صورة

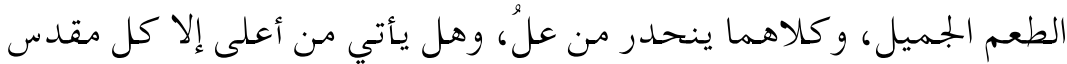
نبيل؟

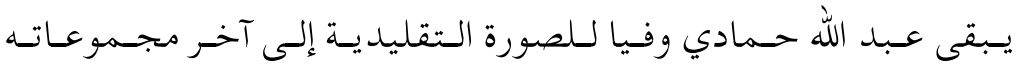
الشعرية، لكنها صور تنم عن إبداع شخصي لا نمطية فيه، ولا تقليد .

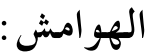

1 مصطفى السعدني : التصوير الفني في شعر محسمد حسن إسـماعيل، مـششأة المعارف، الإسكنرية .دت.ص 85. 2 عبد القاهر الجرجاني : أسرار البلاغة، نشر محمد رشيد رضا، مطبعة الترقي، مصر 1330هـ، ص 347.

3 شوقي ضيف: دراسات في الشعر العربي المعاصر، دار المعارف، مصر،، مكتبة الدراسات الأدبية، ط 2. 1959، ص صد 239. 4 يـنظر: بشـى موسى صالح: الصورة الشعريـة في النقد العربي الحسديـث، المركز الثقافي العربي، بيروت، ط 1، 1994، ص 3. 


\section{5 المرجع نفسه والصفحة.}

6 ينظر : بشرى موسى صالح: الصورة الشعرية في النقد العربي الحديث، ص 3

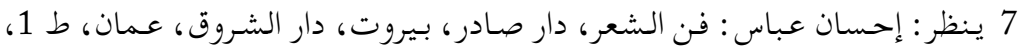

$$
\text { 1996، ص } 200
$$

8 يــظر : أحسمد أمسين: الـنقد الأدبي، دار الـكتاب الـعربي، لـبنان، ط 4 ، 1967، ص 54.

9 مصطفى السعدني : التصوير الفني في شعر محمود حسن إسماعيل، ص 85.

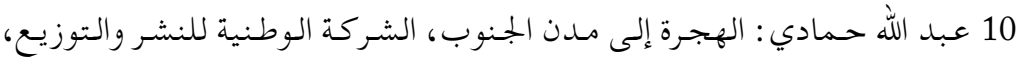

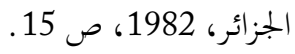

11 مصطفى السعدني : المرجع السابق، ص 256. 12 أحمد أمين: النقد الأدبي، ص 256.

13 الهجرة إلى مدن الجنوب : ص 53. 14 المصدر نفسه : ص 51. 15 عبد الله حمادي : البرزخ والسكين، منشورات جامعة منتوري قسنطينة، 2000، ص 28.

16 عبد الله حسمادي، قصائسد غجريـة، المؤسسة الوطنية للككتاب، الجزائر، 1983،

17 زاهـر الجــوهـر : شـعر المـعتقلات في فلسـطين، بـيت الـشعر الفلسـطيني، رام

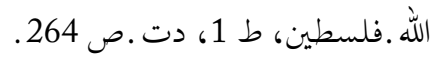

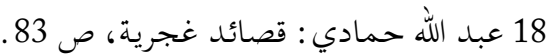

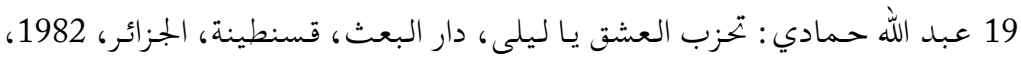




$$
\begin{aligned}
& 21 \text { نوفاليس : فن الشعر: ترجمة رشيد حبشي، مجلة مواقف ، العددان : 25-24، } \\
& \text { 1972، بيروت، ص ص } 207 \\
& 22 \text { تحزب العشق يا ليلى : ص 188-187 } \\
& 23 \text { جوهر زاهر : شعر المعتقلات في فلسطين، ص } 28 . \\
& 24 \text { كرم أنطو ان غطاس : ملامح الأدب العربي الحـديـث، دار النهار للنششر، بيروت، } \\
& \text {. 1980، ص ص } 99 \\
& 25 \text { الهجرة إلى مدن الجنوب : ص } 10 \\
& 26 \text { المصدر نفسه : ص } 11 .
\end{aligned}
$$




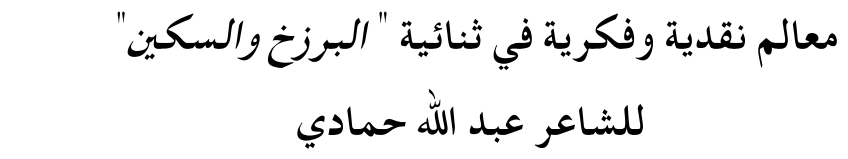

PERSPECTIVA CRÍTICA Y FILOSÓFICA EN LA

DUALIDAD DE $A L-B A R Z A J W A A L-S I K K I N N$ DEL

POETA ABDALLAH HAMMADI

محمد الأمين شيخة

Mohammed Amine Shaika

\section{Resumen:}

El diván poético Al-barzaj wa al-sikkin del poeta argelino Abdallah Hammadi es uno de los divanes excepcionales donde se encuentra la armonía entre contenido y forma y entre el pensamiento clásico y la visión contemporánea. Hammadi realiza su poética desde un planteamiento moderno sin desestimar la herencia cultural araboislámica, sobretodo, en su vertiente sufí, que le sirve para articular su perspectiva, sus sentimientos y su particular visión sobre la realidad. En este diván se aprecia la estrecha relación entre el poeta y su patria, el pensamiento y la literatura, y el espíritu revolucionario del autor y su esfuerzo renovador en la poética árabe.

Este estudio muestra como en Al-barzaj wa al-sikkin se refleja el profundo enlace entre la literatura clásica y moderna en una maravillosa forma artística que evidencia la cultura criticoliteraria del poeta, que le sirve para llegar a la verdad de las cosas y sus esencias, a través de las interrelaciones textuales y las evocaciones producidas tanto por la disposición de los conceptos así como de sus contextos.

Palabras clave:Abdallah Hammadi, dualidad, poesía sufí, poesía argelina, crítica literaria.

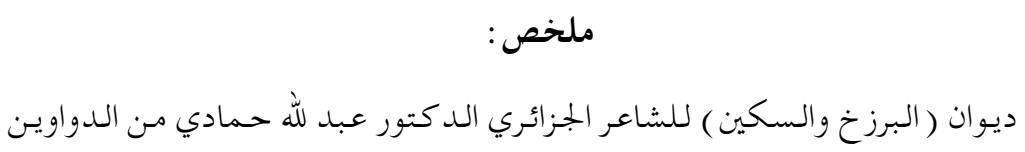


الشعرية الناذرة التي تقاطع فيها الشكل بالمضمون وامتزجت فيها الفكرة الإيديولوجية بالنظرة الحداثية، وقد حاول الشاعر بيان ماهية الشعر من منطلق حداثي غير منسلخ عن الموروث العربي القديم، وخاصة في جانبه الصوفي، فكان هذا الإِبداع بمثابة العتبة الفنية

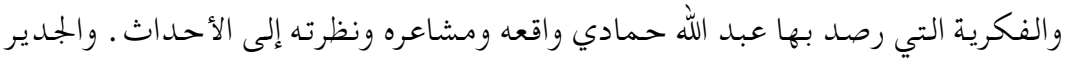
بالذكر أن القارئ لهذا الديوان وما يقدمده من تنظير يلمس ارتباط الشاعر بالوطن فكرا

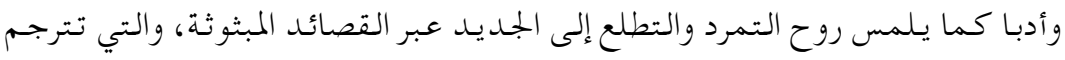

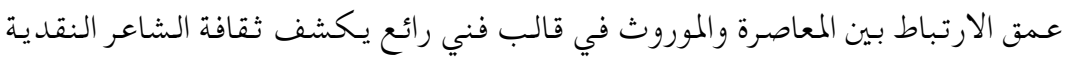

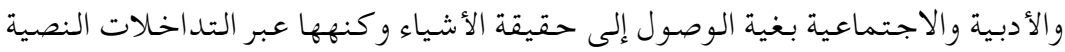
و الإِيحاءات النسقية والسياقية.

مفاتيح البحث : عبدلله حمادي؛ الثنائية؛ الشعر الصوفي؛ الشعر الجزائري؛ النقد الأدبي

لا يمكن للقارى في الفترة الزمنية الحالية أن يتجاهل أو ينكر الأقلام الجادة والمبدعة التي حبرت ومنذ سنوات قليلة نصوصا، وإبـاعات شعرية اتسمت بالغزارة، والخصوبة والتنوع في حياض العمل الأدبي الغني، ومن هذه الأقلام المتخصصة ما جادت به قريحة الشاعر الدكتور عبد الله حمادي خريج جامعة مدريـد المركزية بـاسِبانيا، وأستاذ بكلية العلوم الإِنسانية قسم اللغة العربية وآدابها، والحق يقال أن الرجل صاحبب رؤية فنية نافذة نهلت من منابع الفكر والإِبــاع الـغربي والـعربي بـحكم الـتجارب والـتجاذب مسع الـوسط الثنقافي والأكـاديمي، فـتنوعـت إنـتاجـاتـه بــن الإِبـداع السشعري والـتأليف في مـجال 
الدراسات الأكاديمية والدراسات العلمية الأخرى، والتي جاوزت العشرين مؤلفا في شتى المجالات، ناهيك عن المقالات والدراسات المبثوثة في المجلات

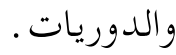

وبحكم احتكاكي المتواضع والبسيط بِِِبداعاته الفنية أحسست بولوع هـذا الرجـل بـالتطور والتجـــيــد ورؤيسته الفنية المـتطلعة إلى كسـر الجـمود

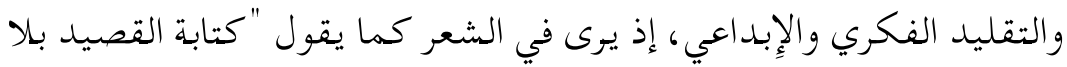

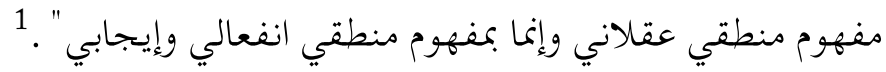

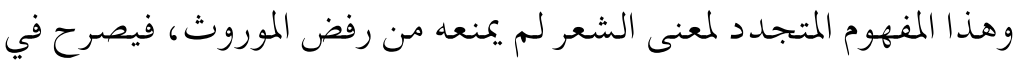

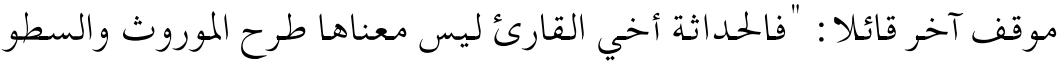
على أنقاضـه الثابتة بمعاول الردة والتشككك والوقوف مـنه موقف الخصمى والتضاد، إن الحداثة بمفهومها الصحيح ... هي البحث المستمر عن إيجاد

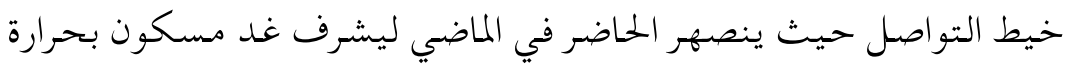
2. الاستمرارية ونبض المعاصرة

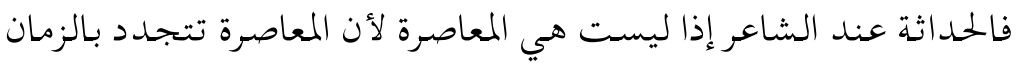
الخـارجي الذذي يـحصر الفترة المعينة، وفيه يـلتزم الشاعر بـترديـد الشعارات السائدة في عصره من دون اختراق هذه الشعارات بل مطابقة المعيار السائد فيها.

وأمام هذه الرؤية المستقبلية للفن الشعري والتي ترجمتها معظم دواوينه

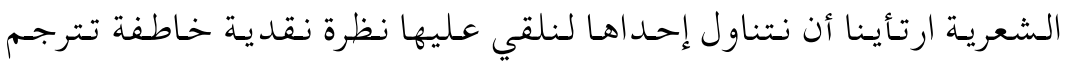
المضمون والشكل، وتحاول بلورة هذه الرؤى واستشفاف الجلديد في عالم وواقع هذا الشاعر، وفي سياق الحديث برزت آخر إنتاجاته الإبـداعية الموسومة 
بـ ( البرزخ والسكين ) من نشر وزارة الثقافة السورية سنة 1998 ثم طبعة من

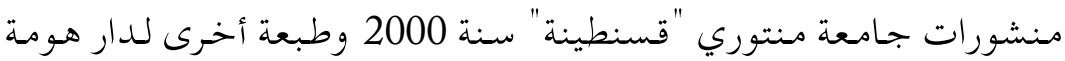

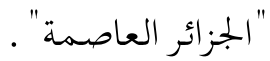

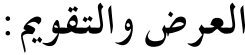

عند تصفح هـذا العمل الأدبي يلاحظ القارئ ميل الشاعر للتنظير في عالم الشاعر ومنه بيان خصائصه وميزاته، فكان تصديره لهذا العمل بمقدمة عن ماهية الشعر على شكل المقدمة التنظيرية التي صدر بها ديوانه السابق (تحزب العشق يـا لـيلى ) دار البعث 1982 وتـكلم فيها عن لوازم الحـداثة والمعارة للقصيدة العمودية، أما في هذه المقدمة الجـديدة فقد رأى الشاعر

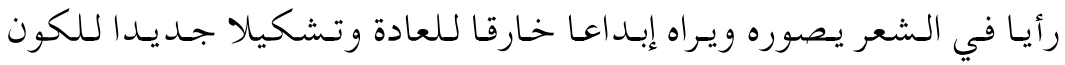
بواسطة الككلمات أو اللغة، واللغة عـنده ليسـت الأسـاس أو القاعـدة لأنها ملك مشاع عند جميع الشعراء والمتشاعرين، فالشعر روح وإيـحاء بـلسان

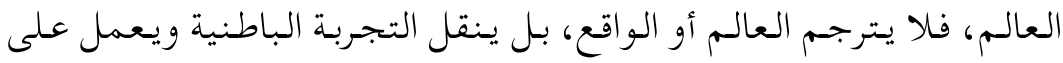

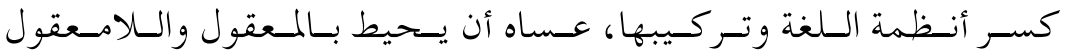
وبالتجارب الباطنية الإنسانية : إن الشعر الحقيقي هو ما يخلف أثرا جماليا

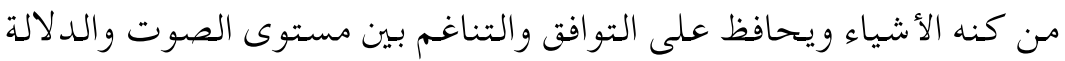

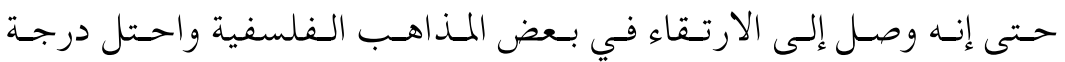
التقديس، والشعر في كل ذلك يهـدف إلى بعث الحسياة في أبهى صورها

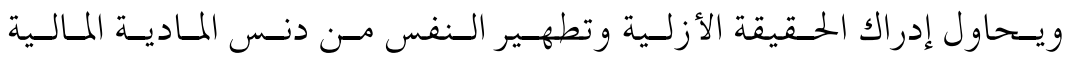
المتعجرفة، فأصبحت أو تصبح الكلمة الشاعرة مـلاذا رحيما مـن جـحيم التقنية المدمرة للذات الإنسانية . 
فالشعر الحداثي بمثابة البرزخ بين الماضي المكلل والمدججج بقو الب السلف الماتف

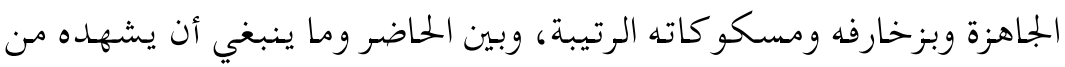

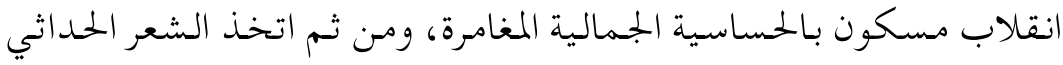
لنفسه مهمة البحث والتجريـب مـن أجلـ خلخلة البنى الذوقية التقليديـة

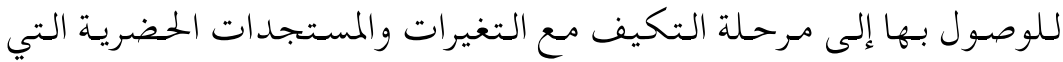
تـنصاع لمـتطلبات الـفكر والـذوق والإحسـاس المـرهـف الـبعيد عـن الـتقليد والاحتذاء، وهي مهمة صعبة جدا تنطوي على قلق دائم لا يعفو عليه الزمان

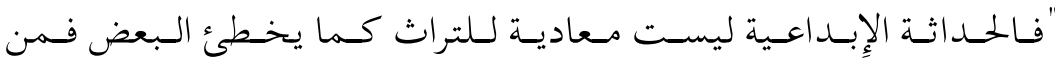

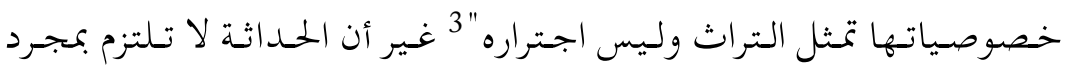
الوجود في العصر والمكان بل تتعداهما بمجموعة انزياحات (Ecarts) - أو بتعبير بسيط - انحرافات أو عدول عن المعيار السائد في الشكل والمضمون لتخاطب القارئ أو المتلقي بـلغة غير اللغة المعهودة وبمعاني مستحدثنة لم لم يألفها العصر ولا المتلقي لها، وبهذا تتحقق الروحانية واللذة التي تكلم عنها

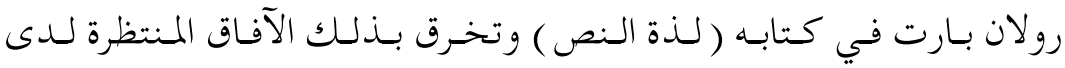

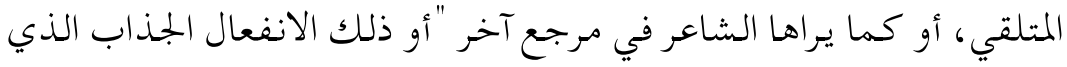

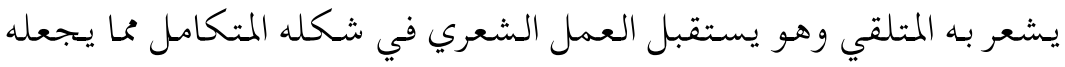

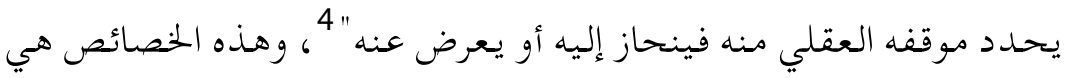

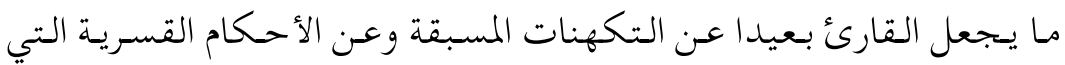
تعود عليها سابقا، ويقلل بذلك من إحساسه بتبعية العمل الأدبي إلى منتجه

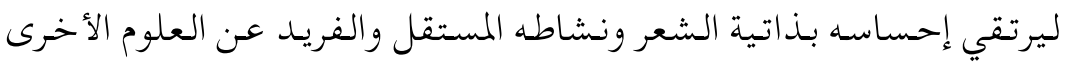
الحافة به كعلم التاريخ أو النفس أو الاجتماع، ولكي يصل المتلقي إلى هذه 
الدرجة من الإِحساس يتطلب منه أن يتوافر على الاستعداد الفني والجمالي

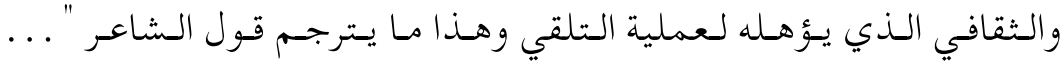
ويتجعل رغبة المتلقي منحصرة في رغبة التصدي حتى لا يقع التجاوز، من هنا تصبح ضرورة وجوب القارئ الممتاز حتمية لا مرد لها" . 5 نرى شاعرنا في آخر هذا التصدير وقبل الخوض في غمار الشعر يكشف عن جـدوى الشعر وفائدـتـه للمجتمع في ظل عصر السرعة والمعلوماتية، وكانت إجابته من خلال مقاطع شعرية للشاعر الإِسباني قوستافور أدولفو بيكر تتضمن سر ديمومة الشعر في ارتباطه بديمومة الحياة وتنوع طبيعتها،

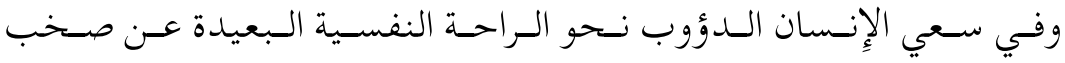

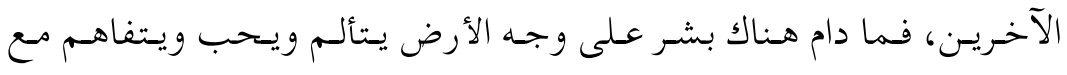

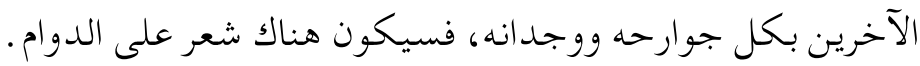

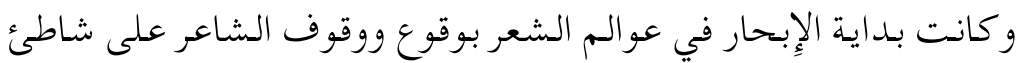
الوطن الحبيب وعلى باب سماه ( كتاب العفاف ) ضمنه أغنيات للجزائر، فكانت قصائده العمودية السبعة بمثابة عرائس بل عجائب العالم السبعة في

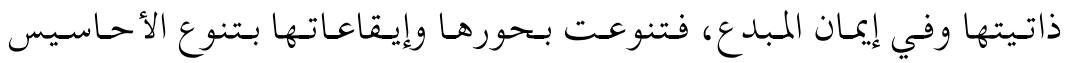
الذاتية، وارتسمت على هذا الكتاب أناشيد وطنية مليئة بالسؤدد والعزة ومشتحونة بطاقات التعبير جسـدت انتماءه الروحي والجسـدي والعقائدي فهذه قصيدة ( جزائر) ) على وزن المتقارب قارب بها وحاكى جمال وبدعة الجزائر في إلياذة مفدي زكرياء ضمنها بطولات ومرآثر الوطن:

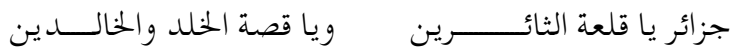
ويا موردا سلسبيل الضلال ويا نشوة من أريج الكـمال 
وعلى وزن الخفيف خفت روحهه وطفت مشاعره وأحاسيسه من الشوق والإِلهام وعشق أرض الجزائر والشجعان : ورن

لا تلمني في حبـها وهواها لست أختار ما حييت سواها

لست أختار فالجــزائر لحني منتهى الوصـل إن أغن بهاها

وعلى إيقاع المتدارك كانت قصيدة ( وطن ) تلامس جسد الجزائر وتعانقه

وطنا يكبر بين الأوطان، عانق الشاعر تراب ورمل الجزائر وطنا كريما:

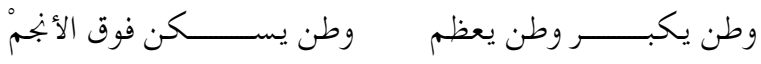

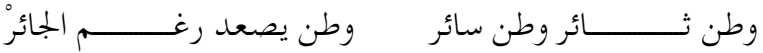

وفي انتقاله لإِيقاع الكامل عاد المبد ع ليردد قصيدته ( الجزائر ) ليلهم الكمال والخلود لأمجادها وبطولاتها ويؤكد ولاءه وحبه لها:

قدر الجزائر أن تكون الأكبرا وتكون سفرا للشهادة أخضرا

وتكون حلـما بالفتوة يانعا وربيع عمر بالنضــارة أجهرا

إلا أن هناك من المتربصين لها والقابعين لنصب شراكهم فكانت قصيدة ( أطفالنا ) " ...فإِلى الحجارة" وبها رسم المبدع صورة أليمة لو اقع الجزائر،

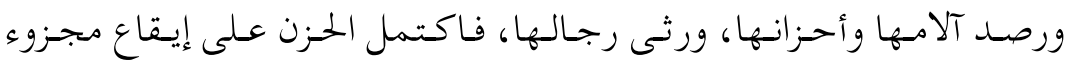

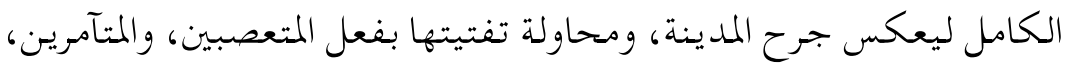

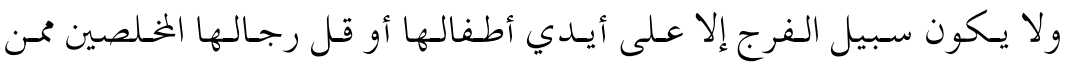
يحاكون أطفال الحجارة في طولكرم، وجنين : قتلوك في وضــــــ النهار وأطلقــــــواعـــــثا إشاره 


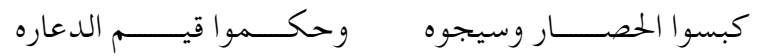

وتنتهي قصة هـذا الكتاب وعلى هـذا الشـاطئ بحـلم وردي يـعانق ذات الشاعر بـقصيدة ( حـلم أزيـلة ) وهي مـديـة مـغربية على المحيط الأطلسي،

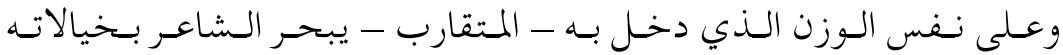
ليستحضر أسفاره وغربة وذكرياته المشـدودة بحمهى الأطياف البعيدة الملقاة على الضفاف الأخرى ليعزم على ركوب المغامرة نحو المجهول : أتنهض بعد السنين الطويله لتعشق طيفا هفا من أصيله

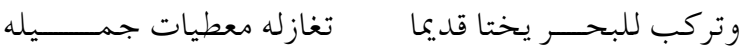
ويواصل:

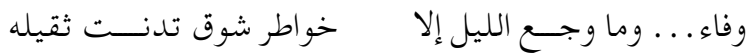

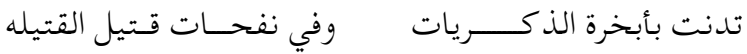

وجـاء الكتاب الثاني بـنقلة نوعية نحو عو المّ الشعر ،ونسو عـالم النور ليستنير بـه المبدع وينير دروب الواقع والعالم الروحاني، وعبر ثالاثين مقطعا ربـاعيا سماهـا ( ربـاعيات آخر الليل ) صدرها بمـا يبر كبحه لنشاط العقل، والمنطق، وتحريـر النفس وخلجاتها مـن سـطتيهما لتعبرا عن ذاتها بـذاتها، فكانت كلمتها حكما وعبرا للناس جالت بها عبر القلب والوجدان، وخفت بـها لـطفو، وتنتشـ في بهـيم الـليل خـفة البحـر الذي سـارت عـلى إيـقاعه، وكانت نقلة النفس عبر هذه المقاطع بمثابة مـن يأخذ مـن كل بستان زهرة، فمن وهج الليل المريـب ينطلق القلب صاحيا من جـديد صحو المغرم الهائم، وتأتي النشوة من حب الصراع والمكابدة، فيتصف الوفاء بذلك سرا للوجود، 
وتلحق بالتمني والتغني والتبني خيبة وعار كبيران :

ما دهاك تقيم صسرح التجني مستبيحا عفافه بالـــتمني

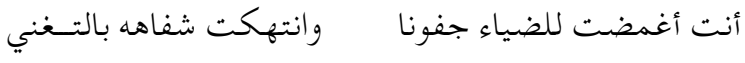

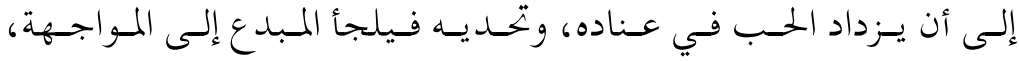

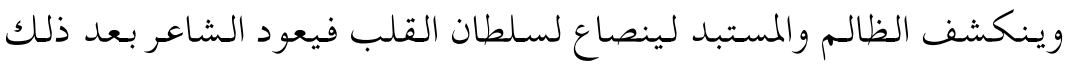

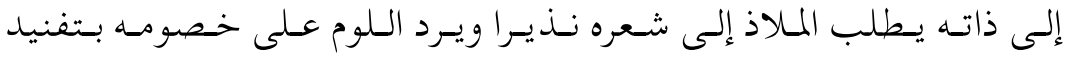
أكاذيبهم، ويقدم النصح والبيان، ويطلب من ثمة العفو والصفح، ويرجو النجاة والانتشال من عالم الحيف والبهتان :

$$
\begin{aligned}
& \text { ظالم أنت فانتســـــب يا غوي وارحم الزهر في حقول الغرام } \\
& \text { واكبح الخوض في مدار التشفي وارحم الزهر في حقول الغرام الترفي }
\end{aligned}
$$

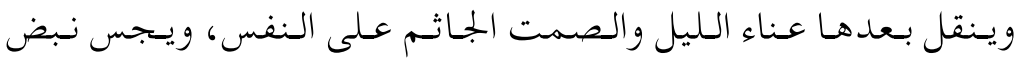
القلب ولواعجه فيرى منه سحرا يتحدى الجوارح ويبحر أمام مخيلة المبدع ليشعل شوقه وهيامه، ويرسم تجاربه ولوعته بالرحيل وراء الأطياف، فكان السلاح الكلمة الشاعرة، وكانت الذخيرة العزيمة والإِقدام:

مرهف الظل يا بهـــي الملام لا تعجلها في حضــور الظلام ضقت بالليل فانتشله رويدا واطلب العفو من ظريف القوام

ثم يعود على إيقاع الكامل ليعطي صورة لذاته هي صورة فكره ووجدانه

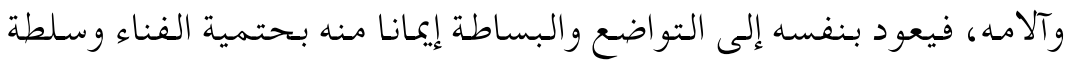

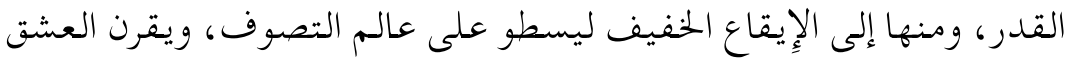
بالصلاة والهوى والسجود بين يدي الحبيبة، وطقوس العفاف: 


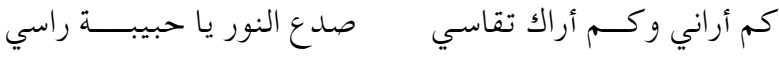

$$
\begin{aligned}
& \text { سفك دمعي على هواك مباح وانتحاري فدا العيـون يواسي }
\end{aligned}
$$

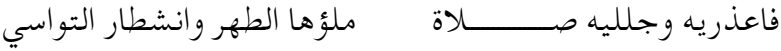

وعلى وزن المتقارب يأتي الصوت ويخبو التمني خوفا من الآتي المخيف، ومسن القادم المتجني، لكن حـب المغامـرة والإبـحار مـكنا المبدع مـن الإحـاطـة بالكون وطوعا له الحمدود ليرقى بـالحبيبة إلى الدرجات العليا، ومسنه أفضى

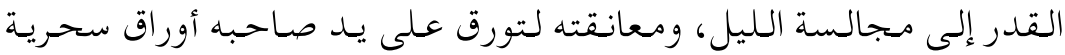
يمتلك بها سر الكلمات والحروف، وبها يكون التجديد والتحديث :

$$
\begin{aligned}
& \text { فِإن أورق الليل في راحتيـك تدنت لك عاليات القطـوف }
\end{aligned}
$$

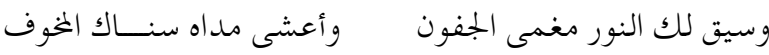

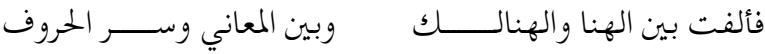

ومن على وزن الخفيف سار المبدع بدعاوى اقتحام المنافي والاصطبار على

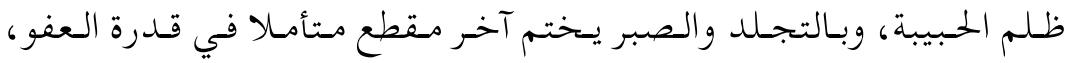
والجزاء والرحمة عند خالقه : موعد العفو والبقــية تأتي فاطلق الحبل لو أردت نجاتي

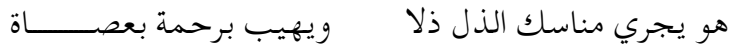

وهذا الكتاب الثالث و الأخير إيـانـا بعودته إلى البدايـة ومعايشه الواقع بمرارته وحلاوته المادية والمعنوية عساه أن يحط رحاله على شاطئ الأمان بعد الإِبحار في غـمار الـذات الشاعـرة، فضـم هـذا الكتاب الـذي سـماه ( كـتاب

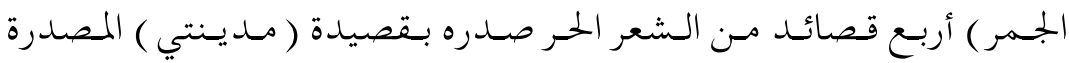


بدورها بآية من سورة الإِسراء تحيل في البداية قارئها غلة ما يستعرضه من

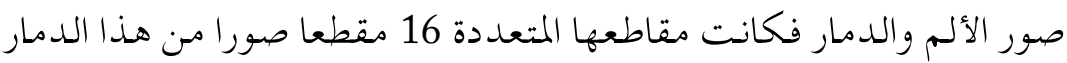

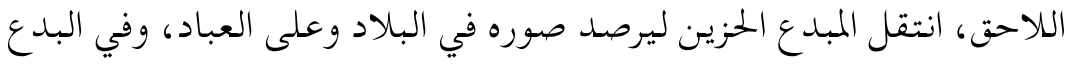

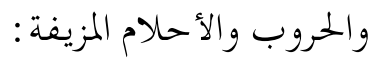

$$
\begin{aligned}
& \text { مد ينتسي ...! } \\
& \text { مدينتي ... مدينتي لو تجهلون في المتون } \\
& \text { مقبـــرة } \\
& \text { أحلامها أوسمة } \\
& \text { وسلع مسهربه } \\
& \text { وبدع مجربه }
\end{aligned}
$$

واستعرض سطوة الظالمين مـن الفجار وممن سماهـم بـالبجوس، من خبث

الانتهازيين، فأحالوا المدينة إلى ساحة دمار وتلغيم وعار:

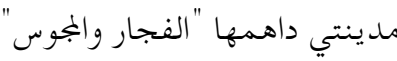

فخيلهـم تدك بــراءة النـفوس

فمديـة الشاعر لا عهـد لها بـذلك لو لا المؤامرة والـدسائسس ،بل إنها أسكتت عن الإفصاح والبوح بقوة هؤلاء فأصبحت أزرى وأذل فلا تسألوها

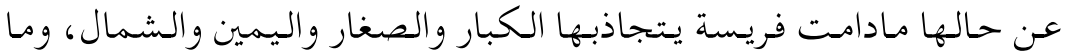

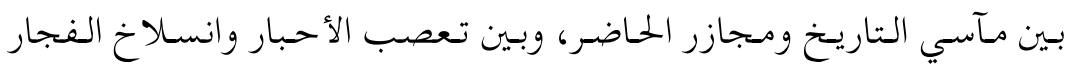
سارت إلى الضياع، و كلهم أبناء المدينة نفسها، وكلهم مغرقوها :

$$
\text { مد ينتي ... مديسنة }
$$

لفظها التاريخ والبخور 


\section{فأشرعت بوابة \\ للككفر والنـذور \\ فطرتهـا اليمين \\ نزوتها اليـسار \\ وعشقها مززق \\ أيهـما تخـتار}

فـلسان الشاعر هـذه المـديـنة وقصيدتـه هي، يحـملها حسيث يسشاء بـعيدا عنهم وعن أعين المراقبين وتأتي قصيدة ( البرزخ والسكين ) لب الديوان وسر وجوده، وقد علق عليها الد كتور حسين خمري قائلا: " ...تجتهد في بعث الجو الصوفي وتوظيف الرمز الذي يحيل إلى ذلك محاولة تحيينها بالراهن "6 6 فهي بـلك إبحار في عالم الحياد والطهر بعيدا عن دنس الحياة، مليئة بالرمز والخيال صدرها بمقولة لأحمد أكبر الفلاسفة العرب ابن عربي -638/560هـ توحي بقدرة الخالق على بعث الحياة بين يدليه وقدرته على بعث من فيها إلى دنيا دائمة أو نهاية حتمية "له النزول ولنـا المعراج" ، وهذه القصيدة الحرة تعتمد على تكثثيف التداخلات النصية من القرآن الكريم والحـديـث النبوي الشريف، ومن أقوال السلف الصالح وتستلهم أفكارها من حوادث هامة في تاريخ البشريـة اعتمد فيها المبلدع على عشرة مقاطع منفصلة، انتقل بها من فكرة الألوهية وتجسيدها في الفكر الصوفي، وفي فضائلها وكراماتها الخارقة إلى فكرة الخطيئة والعصيان مـن أبينا آدم وأمسنا حو اء فكانـت البدايـة وكان البرزخ ومنه تلتها مواقف حاسمة في حياة البشر وصراع بين هابيل وقابيل: 


$$
\begin{aligned}
& \text { كان البحــث مسبوقا } \\
& \text { بغراب يوري سوأة للعاشقين } \\
& \text { لا يا طائر الزمن الخافت } \\
& \text { عاشق جثث ومن خلفي قوافل وأمامي برزخ }
\end{aligned}
$$

إلى صـراع الذات مـع نـسـها في المحبة الإلهـية وتـكريسـها لفنهم حـقائق الكون ودواخله وصـولا إلى حـقيقة الفنـاء، وحـتمية النهايـة بطريـة العذاب

$$
\begin{aligned}
& \text { مسكـونا أنا بنافلة الأطوار } \\
& \text { وبرزخ ما بين عافية وعاقبة } \\
& \text { تتـجاذبـني شفتان } \\
& \text { واحسدة للزهــاوين } \\
& \text { وأخرى خـاتمة للبقرة . }
\end{aligned}
$$

ووسط هذا الصراع كان شاعرنا منزويا في عالم الغفران مخاطبا الكون من بعيد ينتظر ساعة السكون والتي لن تكون إلا خاتمة السكين:

$$
\text { خاقبة البـدء }
$$

و ثالثث قصيدة بعنوان ( يا امرأة من ورق التوت ) ذات المقاطع المتعددة -

14 مقطعا - جـاءت بـتصد يـر تضمن كلمات مـن سـفر التكويـن " التوراة " 
تقص حكاية أبينا آدم وأمنا حواء في الجـنة، وأكلهما من الشجرة المقدسة،

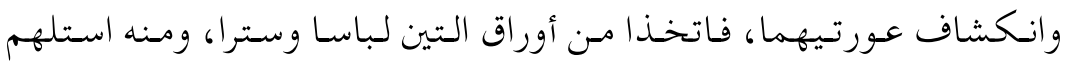

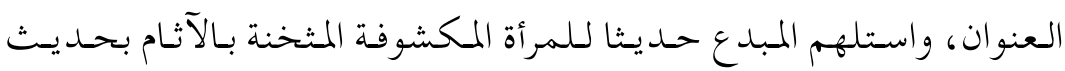
يزخر بالرمز ومبثوث بأفكار التصوف :

$$
\begin{aligned}
& \text { وتقرب بين شفاه امـرأة } \\
& \text { من صسخر } \\
& \text { تنـام في شـرفات } \\
& \text { يزني في محراب عفتها } \\
& \text { حمـام وغــراب } \\
& \text { لا أحد ينفض عن هذا الإِثم } \\
& \text { غوايته }
\end{aligned}
$$

ولقد عـدهـا - أي الـقصيدة - أحهد الـقاد تجـربـة شعريـة حـديـثة تـعتمد على اللغة وتفاعلاتها الجمالية وفي انتقال المبدع عبر هذه اللغة علق خطاياه على باب هذه المرأة التي يراها السند والمعين واكتشف خيانتها فأوقعته في

$$
\begin{aligned}
& \text { علقت عتابي على باب مد ينتكم } \\
& \text { احتــرف العسشق } \\
& \text { واللعـب الآهـلة بالوحسشة } \\
& \text { والغـارات المهزيزومة }
\end{aligned}
$$

وأقـر انهززامـه الـلامحسـدود وهـو مـفتون وأعـمى بـعشقها يسـير في تسيار العاشقين ويجري في مجراهم ويعود بالذ كرى لائما على أيامه الخوالي، أيام 
المـلـيـة الـتي حـفتهما، ويـعاوده الحسنين للطففها كـالطفل بـين الأذرع تـغمره عشقا ويدهشه الاحتراف في عينيها فيتمنى فتاتات من غيثا العميم :

$$
\begin{aligned}
& \text { ما أجمل أن تبعث طفلا مغرورا } \\
& \text { يكــبر فـوق ذراع } \\
& \text { يغمسـد فوق شــفاه } \\
& \text { يرهقـها البـوح وأطيـاف }
\end{aligned}
$$$$
\text { غيبيه }
$$

وفي دأبها يراو ده الحنين إلى الإبحار في عوالمها المليئة بالكتمان والمحكومة بـالسر، فأضحت تحاصـره في صحوه وفي صـلاته إلى حـد أعلن فيه عودتهـ كالمخمور أو الممسوس الذي عاوده المس بعد الشفاء.

ولا بـد أن المرأة هنا كانت المطية أو الجسبر الذي حاول المبدع عبوره ليلبس حقيقة إحساسه ثوبا يناسب المحتوى الذي يصبو إلى تحليله والتعبير عنه .

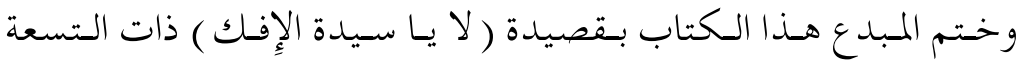
مقاطع والتي تـتداخل تاريسخيا مع حسادثة الإفِك في عهد الرسول ( ص )، ليستلهم المبدع مسن خلالها روح الحادثة ويبدأ عرضـه هـذا من موقع المتهم بالخطيئة في عالم الشعر الذي كثر نومهه فتأخر عن موكب النجاة، وخطر بباله الإِثم حتى تنبأ بالخطر، خطر قبلة على شفة من عبق الأزهار :

$$
\begin{aligned}
& \text { هو السفر الممتد على وجعي } \\
& \text { أيســره العســر }
\end{aligned}
$$

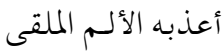

$$
\begin{aligned}
& \text { على شفة من عبق الأزهـار }
\end{aligned}
$$


وأي قبلة يتهم بها المرء، والتي تكسر الحدود وتعبر الشطآن وتقف تمثالا

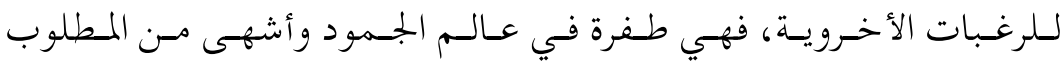
والمرفوض، فيعلن في خضم هذه الصور تبنيه لها لأنها قبلة فردوسية على باب الغفران وكهف الأبرار، قبلة لا تحمل من دنيويتها إلى الإحساس باللذة والمتعة فكانت قبلة صوفية لا دنس فيها ولا إثم:

$$
\begin{aligned}
& \text { يكبر عري في حضن الوجع الليلي } \\
& \text { ما بين المشـعر والجمهرات } \\
& \text { ما أشهى أن أعصـره كرما } \\
& \text { من شفة السكر } \\
& \text { من خمرة الحضرة من فيض الإثم } \\
& \text { من مائـدة الصـديقين. }
\end{aligned}
$$

ومن خلال هذا العرض التفصيلي، والتقويم المبدئي لخحتوى هذه الكتب

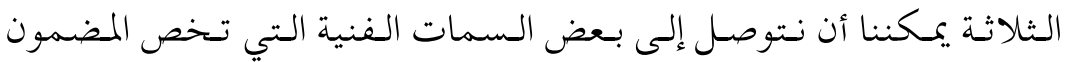
والشكل من خلال تتبع أهم ما ورد في هذه الكتب، ومحاولة إيجاد قاعدة خـلفية نظريـة للظواهـر التي رصـدت وفق بعض المناهج والتيارات النقديـة الفاعلة في الساحة الأدبية. ففي الكتاب الأول كتاب ( العفاف ) الذي ضم سبع قصائد غلبت عليها النزعة الوطنية وروح الإنشادية، وتقاطعت عناوين قصائده في مفصل واحد وقاسـم واحسد هو الجزائر "الجزائر - أرض الحـرية - هي ليلاي - وطـن -

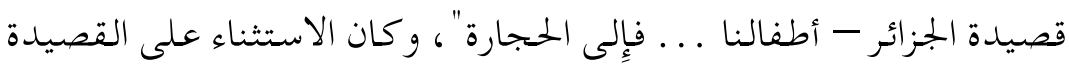




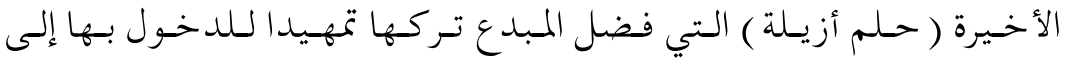
الكتاب المو الي وهو كتاب الإبحار في عوالم الشعر الخفية.

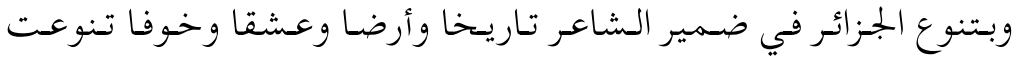
إيقاعاتها لتتغلب الإِيقاعات الصافية وتطغى، وهي إيقاعات محببة للنفس لفس بعيدة عن الحشد والتقرير مليئة بالحركة والتلاحم وهي ( المتقارب - الرمل

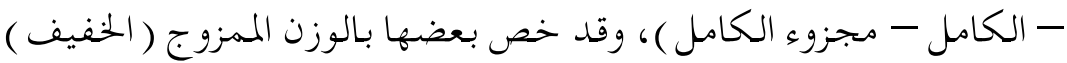
كما لم يغفل شاعرنا تقديره لشعراء آخرين من مثل شاعر الثورة مفدي زكرياء في إلياذة الجزائر حتى إنه ضمن بعض مقاطعه مقاطع من الإلياذة ( يا

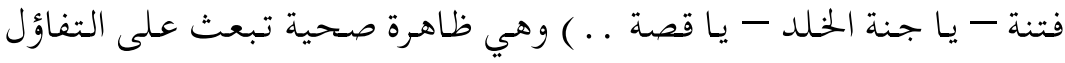

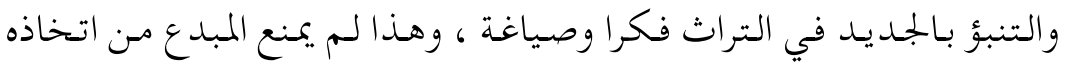

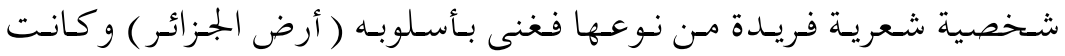
أنشودة من أناشيد الجزائر اعتمد فيها على اللفظ البسيط والجملة الموجزة واللغة السـليمة المستحدثنة ، قامـت الباحيثة "أوديـت بـيتي" في دراستئها لـلفصل الأول مـن كـتاب "الأيسام" لطه حسـين بـطريـقة الجـرد الإِحسائي لمفرداتـه واكـتشفت أن طـه حسـين قـد أخسضع لغتنه لمبدأ الاختيار أعطى القصائد نوعا من المعاصرة وانتقل نحو اللفظ البسيط الفصيح وشيئا فشيئا في القصيدة المو الية (هي ليلاي ) فكانت ألفاظه من مثل ( هواها - مهجتي - وجــ ) نواميس أصلية زادت في ضياء النص، وطعمته برحيق الأصالة،

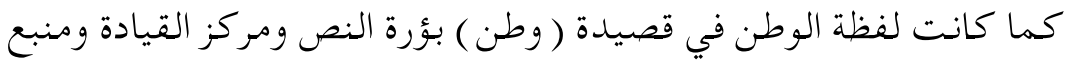
التوليد وبمثابة الأصل الذي توزعت منه الكلمات الأخرى وفي التجاه واحد رغم أن المعجم العربي حافل بمرادفاتها وهذا يحيلنا إلى أن اللغة العربية قد 
تـكتفي - إن صـح الـقول - بمسحور الـتألـيف أو الـتركيب مـن دون مـحور

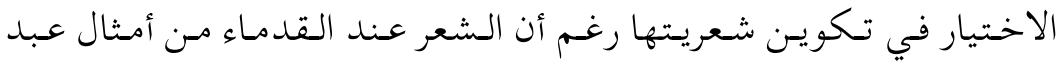
القاهر الجرجاني تـأليف بين الاختيار في اللفظ والتوزيـع أو التركيب في

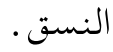

وهو ما تفطن إليه النقاد المحدثون من أمثال "رومان جاكوبسون" و "رولان

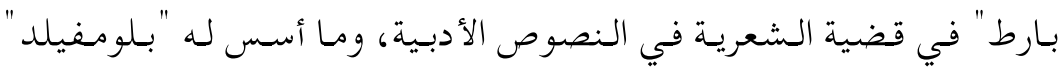
وغيره من قوانين التوليد والتوزيع، وعلى نفس المنوال - تقريبا - سارت

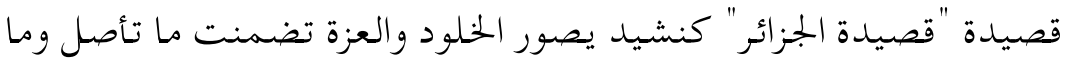
استحدث من لفظ بديع ومن صور زاهية ووقوف على بعض المعالم من واقع

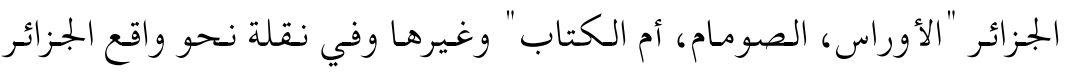

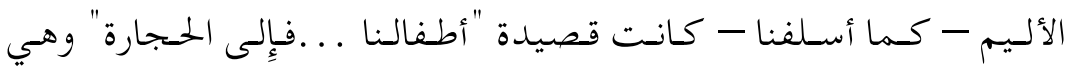
قصيدة تتقاطع مع أحداث فلسطين وثورة الحجارة، حاول المبدع بها الثورة على الأوضاع المزرية، وحاول كشف المكائد المحاكة ضد هذا الوطن فلفظها

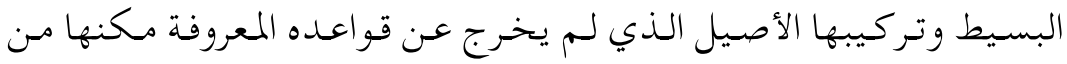
تأدية رسالة إلى المخلصين لهذا الوطن، فكانت الوظيفة الإبلاغية أقوى وأظهر من الوظيفة الشعرية وبدخول المبدع عالم الرؤية والأحلام كانت قصيدته الموالية ليستبطن ذاته ويقف على معالم الذكرى فطغت شعرية القصيدة على وظائفها الأخرى، وبرزت من خلالها بنيتها العمبقة المشحونة بـلالالات المجاز والخيال رغم بساطة الشكل والسطح في اعتماده على اللفظ السليق، والـتركيب المعهود والمجاز الـذي لـم يخــرج عـلى دائرة التشـبيه والاستعارة

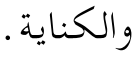


ومما نجمله من خصائص هذا الكتاب وسمات المبدع من خلاله : - التركيز على الكلمات المفاتيح وتقاطعها في مفاصل داخل القصيدة

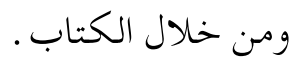
- ارتباط القصائـد برؤيسة واحسدة موحسدة في حـب الجززائر والدفاع عنها والتفاخر بمآثرها . - اعتماد اللغة السليمة ذات التعبير الانفعالي الإيجابي . - الاعتماد على مستويات النحو والبلاغة والتركيب والمجاز المعروفة. - البنية السطحية للقصائـد أدت وظيفة مساعـدة لترجمة معاني البنى

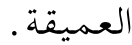
- تـأسيس نـام الـقصيدة الوزن التقليدي وعـلى مـوسـيقى داخـلية غـير طاغية . - غلبة النزعة الوطنية على الكتاب . أما الكتاب الثناني كتاب ( كتاب النور ) والذي تضمن حديـث الشاعر عبر الذات في بهيم الليل وفق الشكل الرباعي ونظام المقاطع والتنويع في الإِيقاع بين الخفيف والكامل والمتقارب، كانت تجربة الشاعر رائدة في رؤية عامة ترى قصور العقل والمنطق حقيقة ثانسية لإِدراك الحـقائق بـدعوة الذات إلى عالم

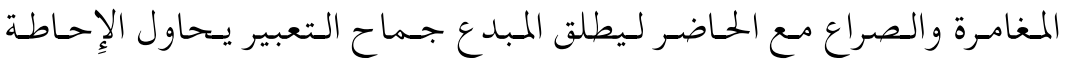
بأسرار الكون فكانـت هـذه الأسرار بمثثابـة حـكم وعبر وقواعد تؤسس لحسياة حقيقية كما تؤسس للتجارب الشعريـة المستقبلية، وبالاعتماد كذلك على

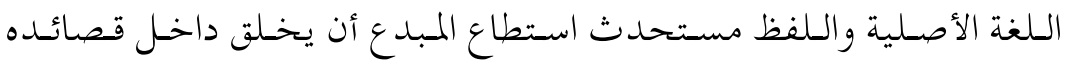
عناصر جديدة فكرية وعاطفية لم تألفها الأذن الصاغية من قبل، وكرس هذه 
اللغة في تشريع الغموض والتلميح كمنهج رائد زاد من ذاتية هذه القصائد، ومن تفردها ومن تمردها على العقل والمنطق الواعيين، ومما رصدناه من معان مفجرة وجـديدة قوله ( واسكب اللحن في مرايـا المنافي ) وقوله ( معبر الإثم محنة تسـتضاف )، و كـلها بـنى مسشحونـة بـدلالات لا عهـد للقارى و والناقـد بها، وما يمكن أن نجمله من مجموع السمات حول هذا الكتاب وصاحبه ما يلي : - دخول المبدع مرحلة تجربة شعريـة جديدة ذات رؤية ثائرة على المعقول والمعهود.

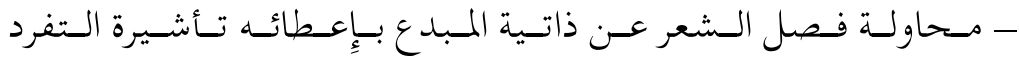
والخصوصية.

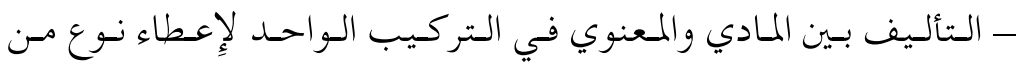
التفاعل بين المتوى الفكري والمتوى المادي. - الاحتفاظ بالوزن التقليدي ومحاولة تطويعه للمحتوى الحداثي . ويسأتي الكتاب الأخـير كـتاب ( الجـمـر ) بمـثابـة قفزة نـحو عـالـم الـتصوف والإِخلاص والطهر الأبدي اعتمد فيه الشاعر على الموروث التاريخي والديني كأساس وقاعدة ينطلق منها ليطلق العنان للتعبير الحر في تفسير الحقائق وفق هـــا المـنظور، فـكان الـقرآن الـكريم والحــــــث الـنبوي الشـريـف والـتاريـخ

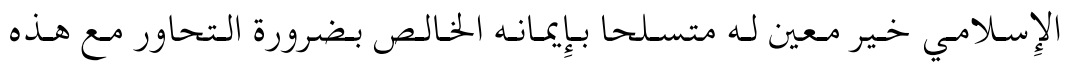
الـنماذج وفت آليات حسددت في الماضسي بـخاصسيات الاقتباس والـتضمين، وحاضرا بآليات التناص عند بـاختين وجوليا كريستفا متما حذا بالشاعر إلى ضـرورة الانزيـاح "Ecart" أحسيانـا بـالفكر والصياغـة الشعريـة إلى صسياغـات 
جــيـدة في قالب الشعر الحـر ذاته، وظهرت تجـديـدات شكلية بسـيطة مـن وحي الشاعر الخـاص جســتهـا تـلك التصورات المتنوعـة مسن فـكر الأديـان واجتهادات السـلف الصالح انتقل فيها المبلدع ليصور الواقع واقع المـديـة

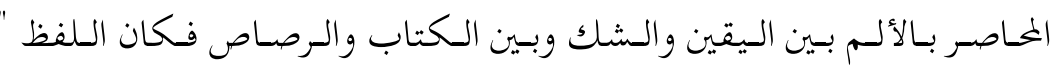
مدينتي " محور كلامهه وعنصر التأسيس في القصيدة الأولى ثم ليعرج بها بهاب على ( البرزخ و السكين ) ويستعرض قصة البداية والخطيئة الكبرى والنهاية

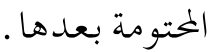

وتليها قصيدة ( يـا امرأة من ورق التوت ) و(لا يـا سيدة الإفكك ) لتسيرا على المنوال السابق ولتجسـا صورة الصراع من الطرف الثاني وفق طقوس

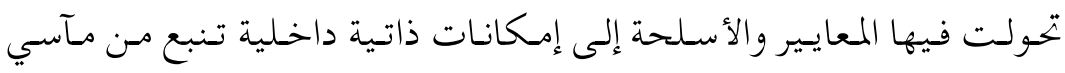

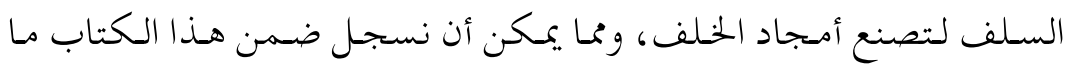

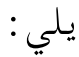
- تأثر المبدع بفلسفة التصوف واتخاذها ميدانا خصبا لصوغ التجارب

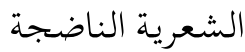

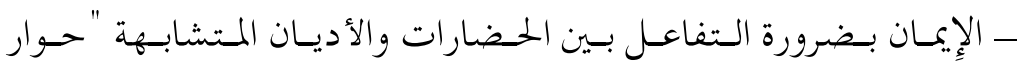

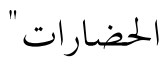
ـ الإِيمان بسلطة النوازع النفسية والجسمدية على الذات البشرية. - الارتقاء بالفكر الإنساني إلى درجات السمو الروحي والعاطفي . - بروز فكرة تطهير الحواس والجوارح لخدمة الأغراض العقائدية. - تطويع اللغة الواقعية للتعبير عن رؤية فكرية غامضة وصعبة . 
- ضرورة التجديد في قو الب التعبير ومححاولة المزج بين المنظوم والمنثور

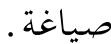

- الاندماج العجيب بين الوظيفة الشعرية وفكرة التصوف عند الشاعر. وإذا تفحصنا هذه الخصائص العامة وهذه السمات الخاصة التي ميزت كل باب على حـدة، ومنها كان الرصد لبعض سمات الشاعر وتفكيره وطبيعة

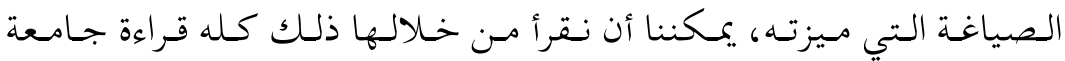

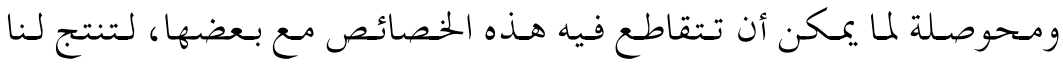

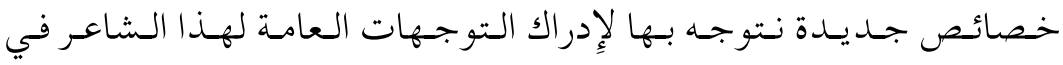

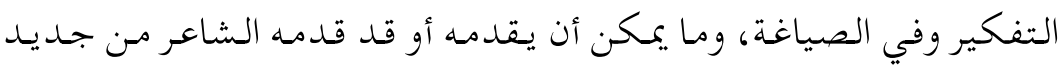
لهذه الحركة الأدبية في الوطن العربي وفي الجزائر بالخصوص.

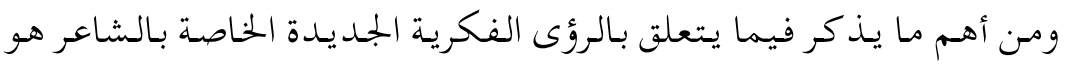

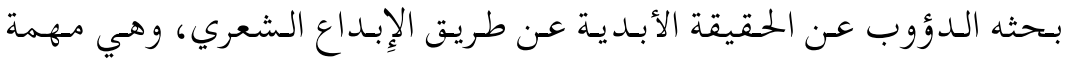
شاقة جدا، ومن المهام التي عجزت أمامها علوم كثيرة كالفلسفة والكهانة وغيرها، ولكنه وفي غمرة بحثه عنها لم يبد يأسه أو إيمانه لفكرة اللامنتمي،

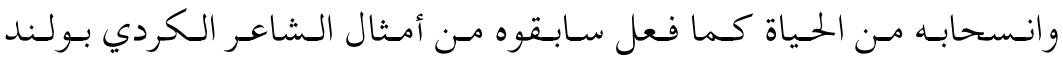

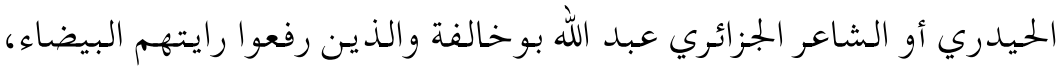

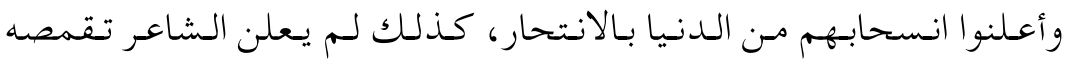
للحداثة المتطرفة والتي تعلن عن انسلاخها التام من الموروث والماضي التليد

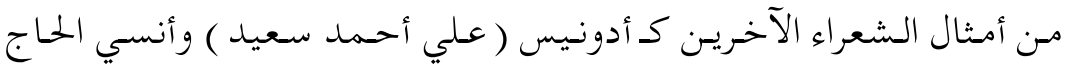
وليلى البعلبكي وغيرهم، بل مد الحداثة ووصلها بالتراث والموروث الثقافي والفكري والأدبي قدر المستطاع، كما أن موقفه من التاريخ لم يـكن سلبيا 
مثلما فعل المفكرون والعلماء المحدثون وعلى رأسهم المفكر الياباني فو كوياما ذو الجنسية الأمريكية والذي أقر بانتهاء التاريخ وموته في الفكر المعاصر، بل كان هذا الأخير - أي التاريخ - المعين والزاد الذي ارتقى به الشاعر ليوظفه في أعماله بصورة أعطت لـه مصداقية وفاعلية جـديـدة، ودعمت آراءه، ونسجت صوره الشعرية.

ومن مواقفه الفكرية المستلهمة من خلال نماذجهـ الشعرية تتجسد فكرة

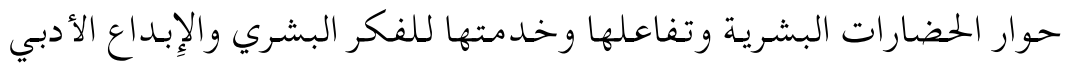
بمختلف صوره، وهو ما جسدته تلك الوقفات أوالخرجات النثرية، واقتباسه

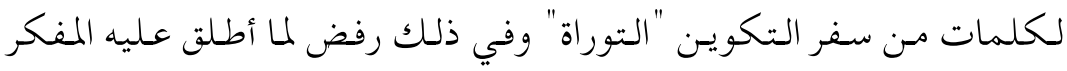

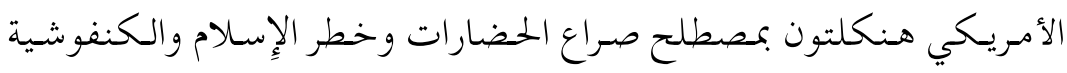

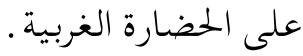
ومما يسجل له كمبادرة حسنة في الإِبداع الشعري هو إحياؤه لمصطلح المدينة المانحة في الأدب العربي بعدمها أصبحت المدينة في الشعر العربي

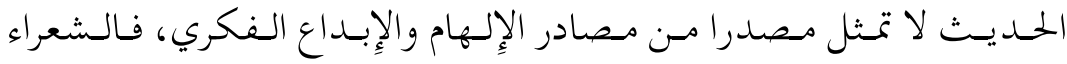

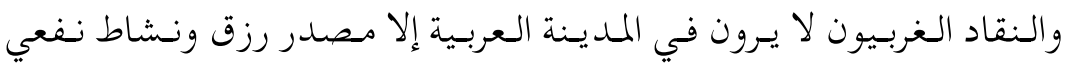

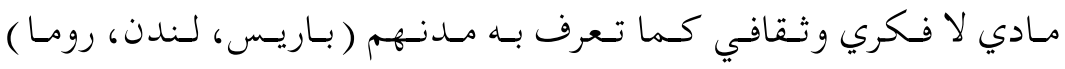

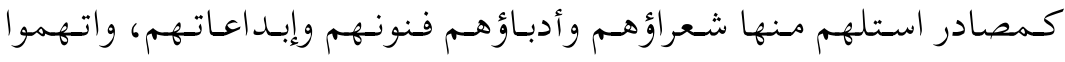

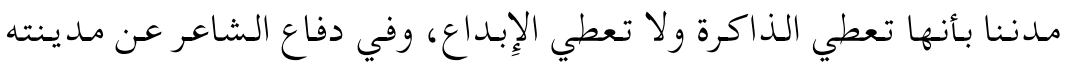

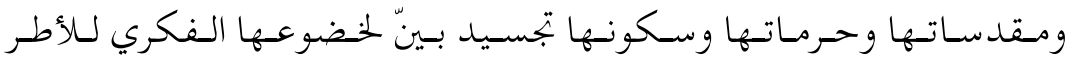

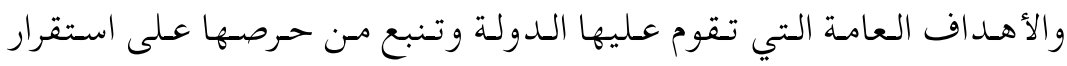

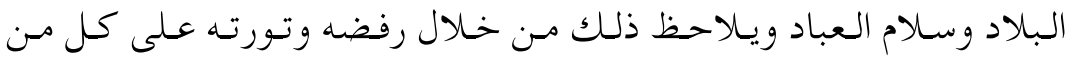


يسـعى إلى تهـد يــد أمسن الـبلاد مـن الانـتهازيـين و السـلطويسين والمتعصبين

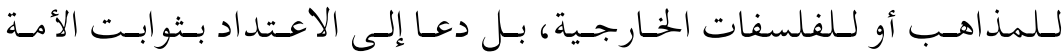
وبـالتراث العقائـدي الزاخـر بـالعطاءات الفكريـة المتنوعـة التي تخـــم التراث الثقافي والتجـد د الحمضاري المؤسس عـليها، وهـو بـذلك يـحاول مـد جـسور التواصل بين الضفة الشرقية للوطن العربي بـالضفة الغربية، ويؤ كد على أن الحضـارة الإِسلامية والعربية واحـدة موحسدة برؤيـة فنية واحسدة ثريـة بـامتزاج القوميات والثقافات، ومجسدة لامتد اد حضاري يتوسط هذا العالم ويـحاول إنشاء جبهات دفاع صادة لختلف التيارات الفكرية والثقافية والأدبية الوافدة من كل جهة على جسد هذه الأمة الطاهر . أملا بخصوص المبادرات الفنية الأدبية التي اتضحت عند الشاعر من خلال هـذا الـعرض والـتقويم المجهمل مـا نـتناولهه في كـتبه الثناتثة، والـذي يـعد مـن

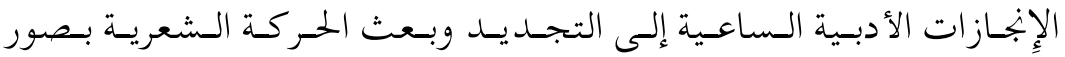
مستحدثة ما نلحظه في تأليفه بين الوزن أو الإِيقاع العروضي الخليلي والوزن الشعري الحر هذا الأخير الذي أسهم فيه شعراء من أمثال نازك الملائكة و بـدر شاكر السياب وغيرهم، وقد أظهر الشاعر تمكنه من نظم أفكاره على الوزنين المختلفين، وتحميلهما لمعان لم تكن لتظهر لولا قدرته على تطويع الوزن الأول لخدمة الفكرة وتأديـة الرسالة الإِبالاغية، و تكليف الوزن الثاني لتبني الشعور والإِحاطة بـالانفعال كما نـالاحظ بـجالاء تـلويسحه بـالكلمة الشاعرة المثقلة بالإِيحاء و الدلالة وانتقاله بها من مجال إلى آخر محاولا كسر كل جمود بين العبارات والتراكيب التي توارثتها الشعوب العربية واتخاذها كسلاح فعال في مواجهة الزخم المعجمي الذي تتداوله الأقلام الشعريـة الأخرى، فكانت 
بذلك محور الحـدث الإبـداعي ونواة الصياغة في العمل الأدبي كما أنه لم يفتأ على مداعبة اللغة والتلاعب بتشكيلاتها اللفظية وتطعيمها بمشمومات عـلم البلاغـة فكان الرمـز أداة للتعبير في أقصى صـوره وكانـت الأسطورة مرجعا للتجربة الإنسانية المشتركة، وكان الخيال هامشا للحرية والانطلاق، وبـذلك حاول أن يجـد لواقعه معادلات موضوعية - حسـب تعبير الـناقــ

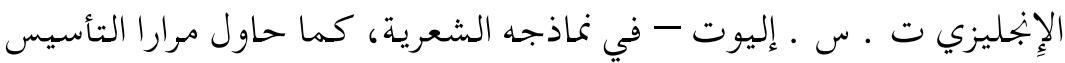

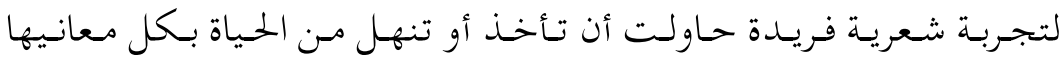

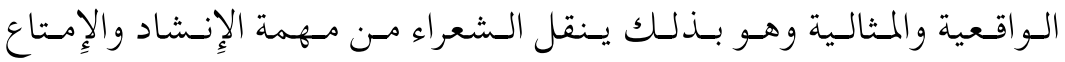
والانحياز للغير لمهمة أشـد صعوبة تحاول وضع الشاعر أمام رسالة إنسانية تهـدف إلى تنشيط كوامن الحياة في الإِنسان ودعوته إلى التأمل والتدبر في ما يحيط به من كائنات مرئية و لامرئية، كما تحاول هذه التجربة الشعرية بيان أهمية الوظيفة التي يؤديها الشعر من خلال الشعر نفسه كأداة وسلاح وكيان يفرض ذاته بذاته من خلال شعريته وانزياحه عن الأدوات الحافة به.

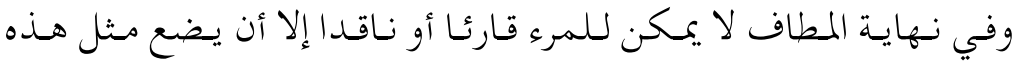
التجارب في مواضعها التي تستحقها تقديرا وإعجابا، لا من قبيل التهليل الانطباعي أو الانفعالي بل على أسس موضوعية ترى بأعين ماورائية نافذة

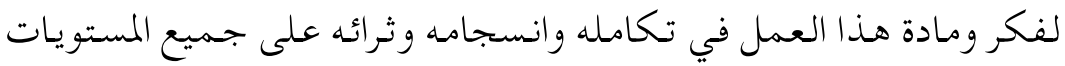

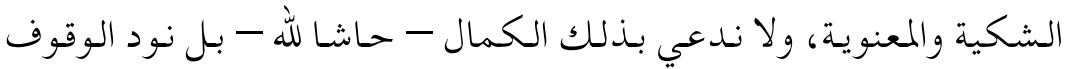

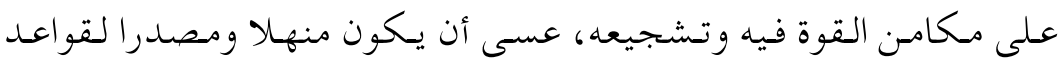

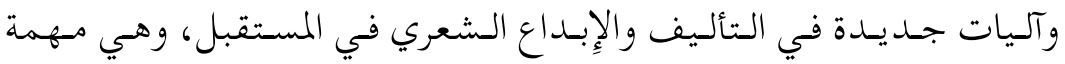
مو كملة إلى النقاد بالخصوص، وما محاولتنا هذه إلا مبادرة ذات نية حسنة 
تهـدف إلى لفت انتباه هؤلاء لدراسة هذا العمل، ومحاولة استغلاله لإضاءة بعض الجوانب التي أغفلناها قصدا أو دون قصد .

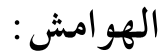

1 ع عبد الله حسمادي : مـــــل إلى الـشعر الإِسـبانسي المـعاصـر ( دراسـات ) 1985،

ص 242.

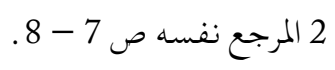

3 عبد الله حسمادي : الـبرزخ والسكين ( ديسوان شـعر )، جـامعة قـسنطينة، 2000،

4 عبد الله حسمادي: مساءات في الفكر الأدبي، ديوان المطبوعات الجامعية، 1994،

$$
\begin{aligned}
& \text {. } 208 \\
& 5 \text { المرجع نفسه ص } 213 . \\
& 6 \text { حسـين خـمري: "شعريـة الانزيـاح في قصيدة يـا امـرأة مـن ورق الـتوت" ، مجـلة } \\
& \text { الآداب ( جامعة قسنطينة ) العدد والسنة؟ ص سمرين } 180 .
\end{aligned}
$$




\title{
أفق التوقع في ديوان "أنطق عن الهوى" لـ : عبد الله حمادي \\ EL HORIZONTE DE EXPECTATIVAS EN EL DIVÁN ANTIQU 'AN AL-HAWÀ DE ABDALLAH HAMMADI
}

\author{
قاسم المسعود \\ جامعة قاصدي مرباح - الجزائر \\ Kassem Masoud \\ Universidad Kasdi Marbah
}

\section{Resumen:}

En este artículo pretendemos tratar el fenómeno literario conocido como "el horizonte de expectativas" del lector aplicándolo al diván poético Antiqu 'an al-hawà, de Abdallah Hammadi. De igual modo, destaca-remos como fue la recepción del contenido de esta obra entre los críticos literarios que la han tratado. Además, subrayamos las distancias estéticas de la obra en cuanto a sus verso poéticos y, como ha conseguido su autor romper el horizonte de expectativas para el lector.

Palabras clave: Abdallah Hammadi, horizonte de expectativas, fusión de horizontes, distancia estética, crítica literaria.

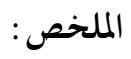

$$
\begin{aligned}
& \text { في هذه المقالة نحاول أن نتناول الظاهرة الأدبية المعروفة بِإسـم "أفق التّوقِع للقارئ" }
\end{aligned}
$$

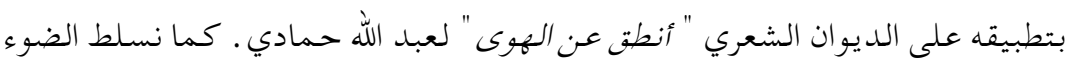

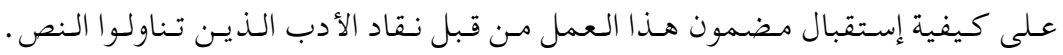

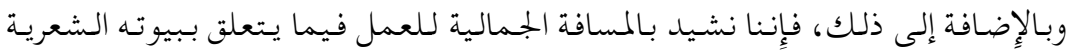

$$
\begin{aligned}
& \text { وكيف تمكن المؤلف من كسر أفق التّوقِع للقارئ. }
\end{aligned}
$$

مفاتيح البحث : عبد الله حمادي؛ أفق التوقع؛ اندماج الآفاق ؛ المسافة الجمالية؛ النقد 


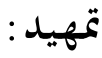

يعد الشاعر "عبد الله حمادي" أحد أهم رواد حركة الشعر؛ إذ تميز بموهبة

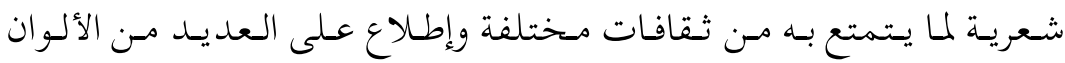
الشعريـة الخختلفة من شعر الغزل إلى شعر الحلكمة، وأشعار الصوفيين العرب فئس مـثل الحلاج وابن عربي، التي استخدمهـما كأقنعة لأفكاره وتصور اته في

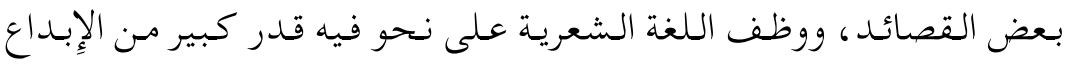

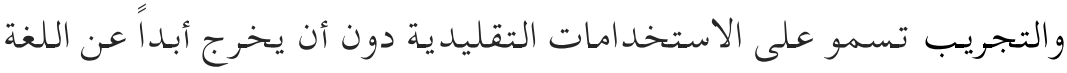
العربية الفصحى ومقاييسها النحوية، وهو ما يعكس وعي تجربته الشعرية

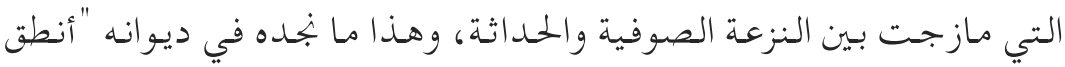

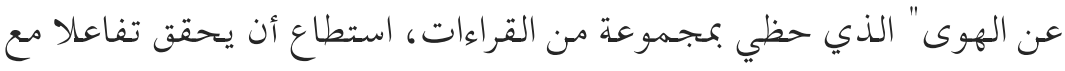
القراء، فكيف كان تلقي الديوان؟ وكيف كان أفق توقع القراء؟

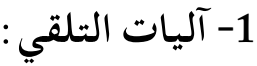

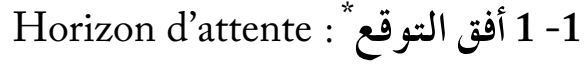

يعد أفق التوقع عند "ياوس" حجر الزّاوية لجمالية التّلقي ويسمى أيضا

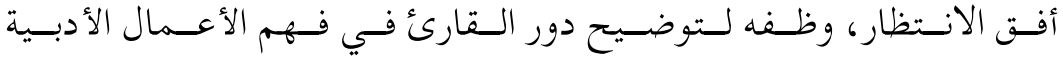

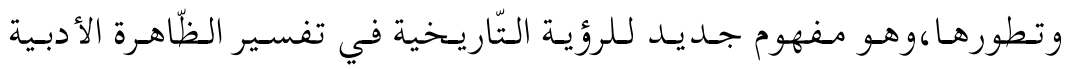

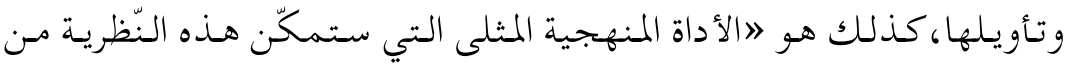
إعطاء رؤيتها الجديدة، القائمة على فهم الظّاهرة الأدبية في أبعادها الوظيفية والجمالية والتّاريخية مس خلال سيرورة تلقيها المستمرة [ [. . أفق الانتظار تتمكن النّظرية من التّمييز بين تلقّي الأعمال الأدبية في زمن ونس 


\section{ظهورها وتلقيّها في الزّمن الحاضر مرورا بسلسلة التّققيّات المتتاليةه1.}

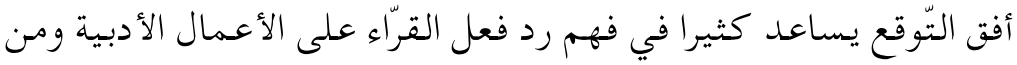
خلاله يتم بناء المعنى وإنتاجه، وتحديد الأهمية التّاريخية والجمالية للعمل كلئل الأدبي وذلك من خلال استمرارية الحوار بين العمل والجمهور المتلقيّ. كما يعد الأفق ״الفضاء الذي تتم من خلاله عملية بناء المعنى ورسم الخطوات المركزية للتّحليل ودور القارئ في إنتاج المعنى عن طريق التّأويل

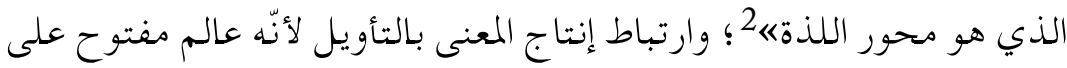
ثقافة وخبرات القارئ التي يمارس بهها التّحليل،فمسن تنوع القراء واختلاف خبراتهم وثقافتهم أصبح لكل عمل أدبي عدد لا متناه من التّأويلات .

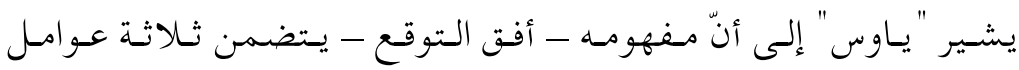

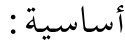

1 - التّجربة المسبقة التي اكتسبها الجمهور عن الجنس الذي ينتمي إليه

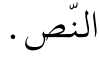

2 - شكل الأعمال السّابقة وموضوعاتها التي يفترض معرفتها .

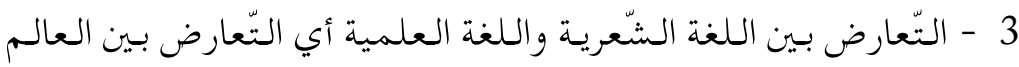

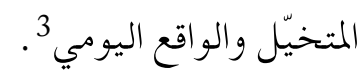

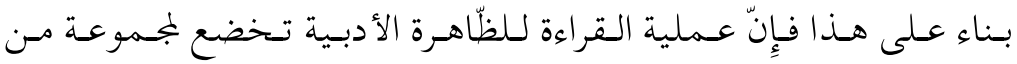

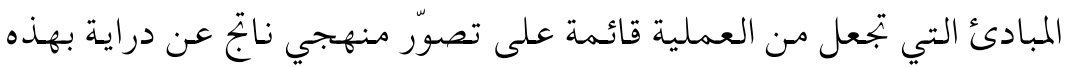

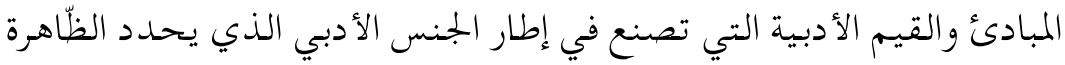

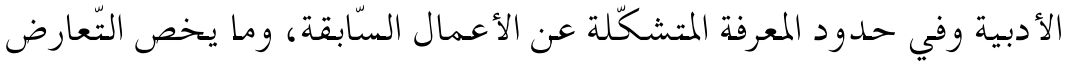

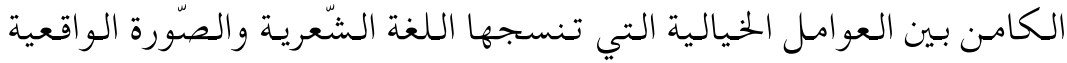


التي ترسمها اللغة اليومية، حيث تكون هذه عبارة عن معايير كفيلة بالقراءة الصّحيحة.

وكل قارئ يقبل على النّص وله خلفية معرفية تؤدّي إلى تكويـن تصوّر مسبق، يجعله يحمل أحكاما يطرق بها باب العمل الأدبي، فيعيش القارئ

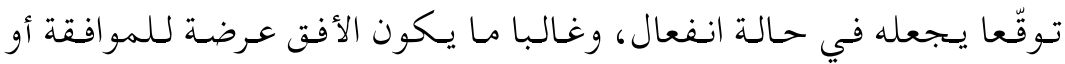

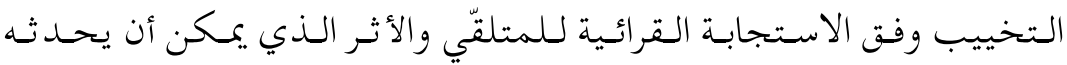

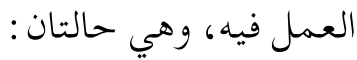

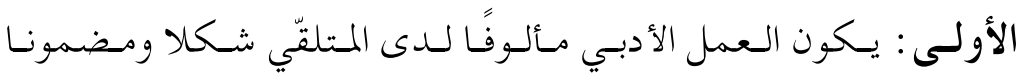
ويتماشى مع المعطيات التي عهدها في قراءاته السّابقة يكون عندها الانطباع فاترا، كقراءة قصيدة مكتوبة بمعايير معهودة، بالتالي هي مألوفة فلا يتشكّل أي انطباع حولها. الثانية : يكون العمل الأدبي مسناقضا ومخالفا لتوقّعات المتلقيّ حيث يخيب ظنّه وهذا ما يعرف بـ( خيبة الانتظار ) أو ( كسرالأفق ) .

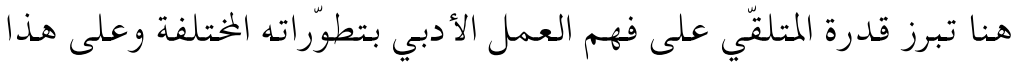

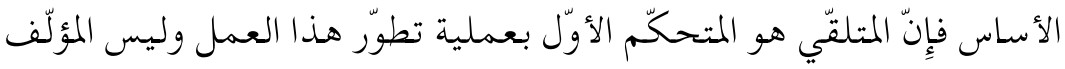

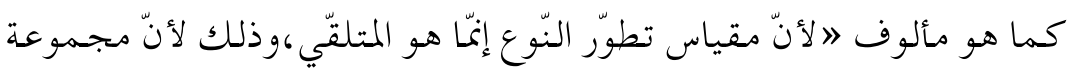

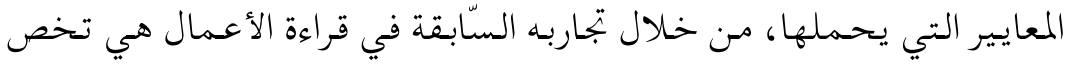

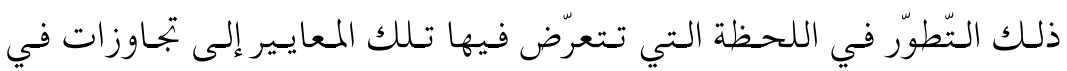
الشّكل واللغة،وهذه اللحظة هي لحظة "الخيبة" «" .

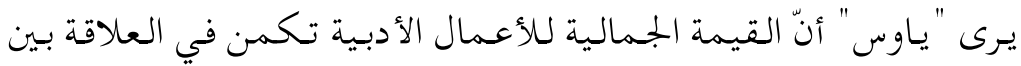

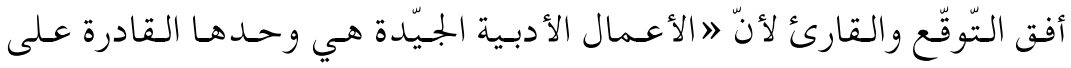


جعل أفق انتظار قرّاءها يكمن بالخيبة، أمّا الأعمال البسيطة فهي تلك التي

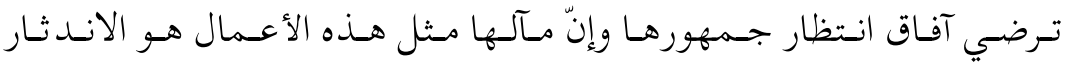

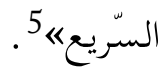

أي أنّ الأعمال الجيّدّة هي التي تخيب آفاق القرّاء، بينما الأعمال التي

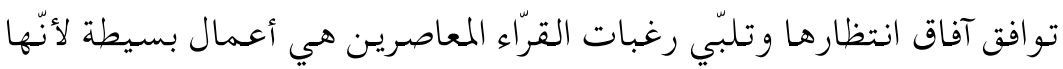

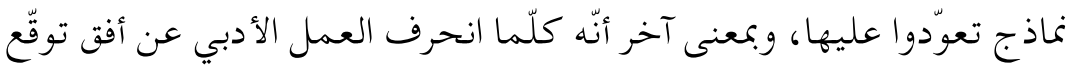

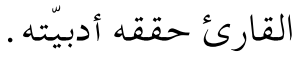

\section{Distance Esthétique : 1 المسافة الجمالية}

هي مفهوم يتمّمّم مفهوم الأفق ويعضّده، وهي من أهم الأدوات الإِجرائية

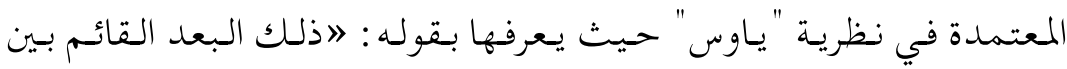

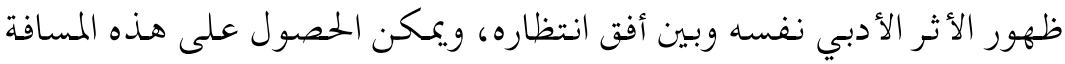
من خلال استقراء ردود أفعال القراء على الأثر أي من تلك الأحكام النقدية التي يطلقونها عليه《6. هي المسافة الفاصـلة بـين أفق الانتظظار الموجـود سـلفا والـعمل الأدبي

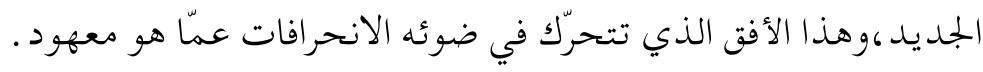

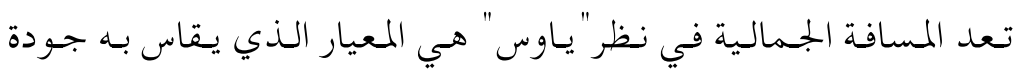

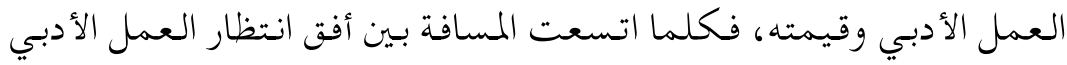
الجلديد وبين الأفق الموجود سلفا ازدادت أهميته (عمل فني رفيع) ) ولكن عندما تتقلّص هذه المسافة يكون العمل الأدبي بسيط ورديء. 


\section{Fusion des horizons : 1}

يستعمل هذا المفهوم لتفسير ظاهرة التّأويلات المختلفة التي يعرفها العمل

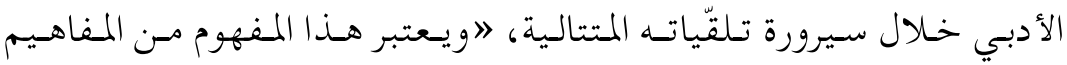

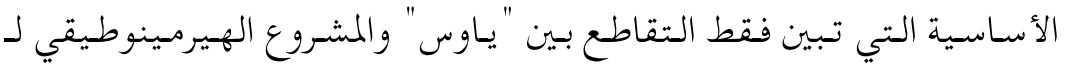

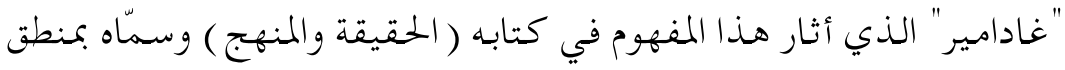
السؤال والجواب الذي يحصل بين النّص وقارئه عبر مختلف الأزمان، ويعبر "ياوس" بهذا المفهوم عن العلاقة القائمة بين الانتظارات التّاريخية للأعمال الأدبية والانتظارات المعاصرة التي قد يحصل معها نوع من التّجاوبهـ"

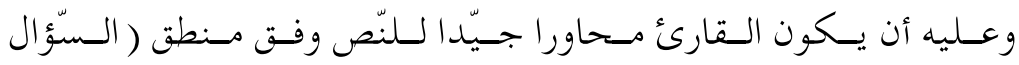
والجواب ) إذ ينطلق السيّؤال من القارئ إلى العمل الأدبي يستنطقه الإجابة،

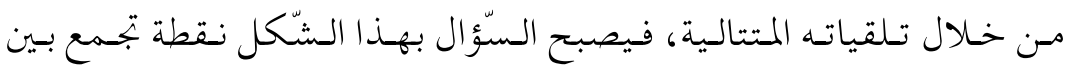

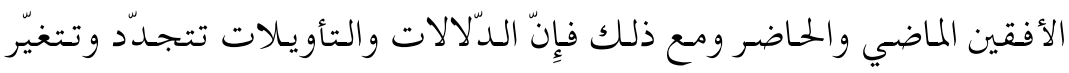
في ظل هذا الاندماج للآفاق والقارئ يـلتقي مع العمل الأدبي عبر أسئلته الخاصة مستحضرا في الوقت ذاته الأسئلة التي ألقيت على العمل عبر تاريخ

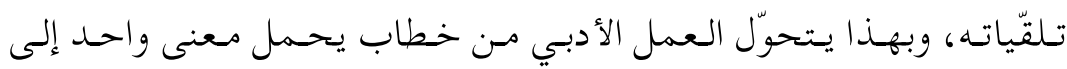

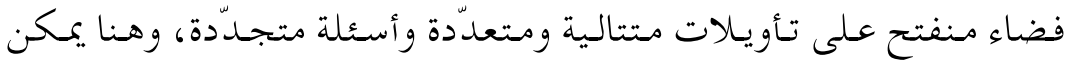

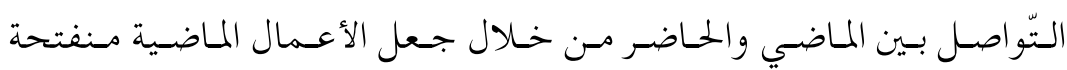
باستمرار على اللّحظة الرّاهنة.

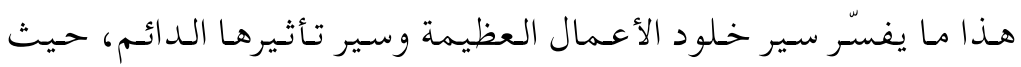

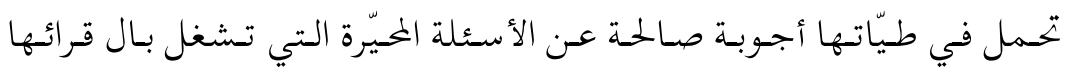

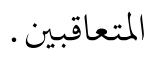




\section{2- ديوان أنطق عن الهوى بين التلقي و أفق التوقع :}

تعد التجربة الشّعريـة وليدة الحياة في تفاعلاتها ومؤثراتها، حيث قاته

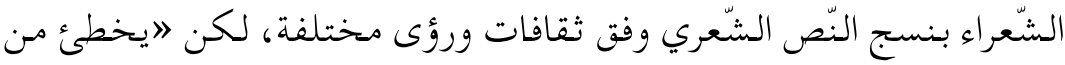
يظن أن التّربة الشّعرية عمل فردي يقوم به الشّاعر وحده وحسب، ذلك ذلك أنّ

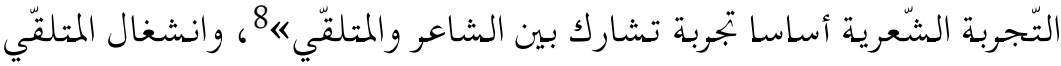
عن الشّعر يفقده معناه وقيمته بل جـدوى وجوده، فالمتلقيّي هو الذي يقوم بتحقيقه وإعادة إنتاجه، والتّلقي فعل ينشأ مع ميلاد النّص، ويلازمه ملازمة حتمية.

مـن هـا المنطلق نقوم بـدراسة تـقّي شعر "عبد الله حمادي" في تجربتـه الأخيرة " أنطق عـن الهوى" ، والوقوف على التّنوع القرائي الذي عرفه هـذا

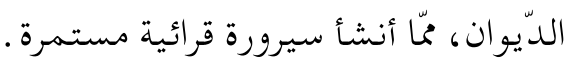

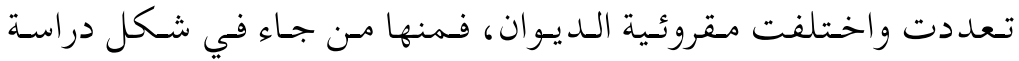

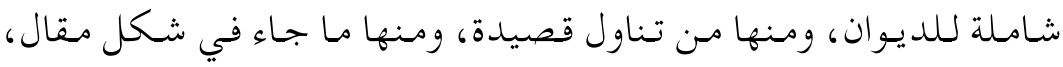
والاخـتلاف كـان في استـخدام أدوات المـنهج في الـدراسـة الـتطبيقية؛ لأن

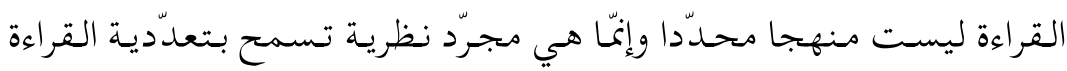

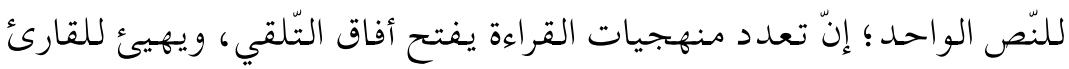
الوقوف على مغاليق النّصوص مع محاولة ولوجها وبلوغ أقاصيها .

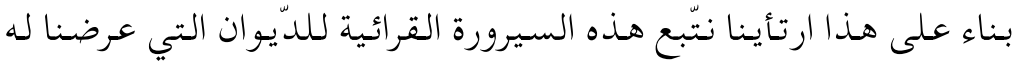
بالدرّ وس والتّحليل لرصد جمالياته ه.

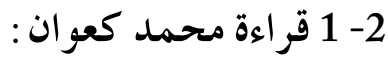

يشـير "محسمد كعوان" في قراءتـه لـقصائـد "عبد الله حسمادى" إلى أنّ 
نصوصه الشعرية هي كتابات صوفية، إذ يقول : لايعمد الشّاعر في العديد من نصوصه إلى قلب المقولات بما يـتماشى مع رؤيته الصوفية، لأنّ الكتابـة الصّوفية هي فيض رؤيوي تحكمه المفارقة، 9

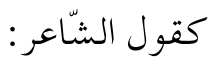

$$
\begin{aligned}
& \text { سادنة الأفلاك ... وغاشيـه الغفران }
\end{aligned}
$$

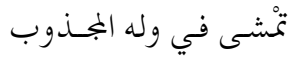

$$
\begin{aligned}
& \text { تسـرج باليمسنى جـــوة نار } \\
& \text { تحمل باليسـرى شربة مَاء } \\
& \text { تشعل بالنار الجنة } 10
\end{aligned}
$$

كما أشار أيضا أنّ نصوصه احتضنت نصوصا غائبة لاحيث يوظّف تلك النّصوص بـطريسقة حواريـة [ . . ] فـالنّصوص التقرآنسية، والمقولات الصوفية والموروث الثقافي جلها حقول يتأسس عليها الخطاب الشعري عند "عبد الله حمادى" "11

القارئ هـنا اتجهه إلى هذا النص الشعري بحسب الثقافة والموروث الخززن في ذاكرته، إذ يراه حافل بـالخطاب الصوفي، وأن الشاعر نهل من التراث لإثراء تجربته الشعرية، والانتباه لهذه الخصائص الفنية، يعود إلى جملة من المعارف السابقة عن هذا الجنس معتمد على التأويل . 2- 2 قر اءة نبيل لنصاب :

الجـهـ هـا القارئ في قراءته لهذا الديوان إلى إبراز فاعلية المنهج الأسلوبي في الخطاب الشعري، واستتباط جـماليات النص وشعريـته المتواريـة خـلف اللغة وفت معايير فنية منها الإِيقاع والتكرار . 
- الإيقاع: يرى القارئ أن "عبد الله حمادي" قام بتوظيف بحور جعلها إطارا صوتيا تدور حوله القصائد الموجودة في الديوان، حيث جاءت أغلبها

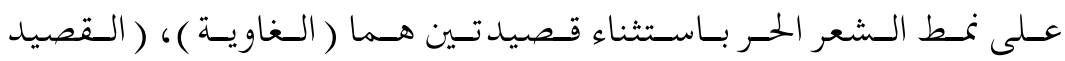
الانتحاري ) اللتين جاءتا على نمط الشعر العمودي 12.

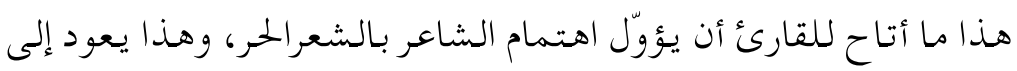
الانتشار الكبير الذي عرفه هذا الأخير في العصر الحمديث والمعاصر، وكذلك هنك كونه أفضل أنماط الشعر التي يجد فيها الشعر حرية في التعبير عن مشاعره.

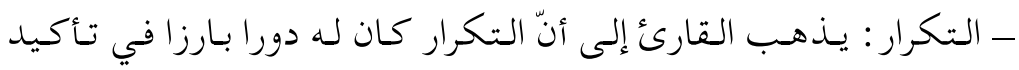
المعاني التي أرادها الشاعر، أو إحداث تناغما موسيقيا داخل النص الشعري؛

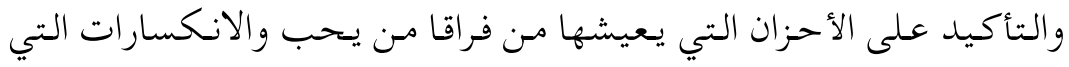
عاشها13، مثل قول الشاعر: مئل

$$
\begin{aligned}
& \text { يدها في يدي } \\
& \text { والفراشات هلكى } \\
& \text { والمتاهات تقضي }
\end{aligned}
$$

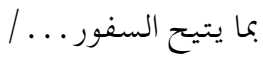

$$
\begin{aligned}
& \text { يدها في يدي }
\end{aligned}
$$

وعليه فالتكرار، وفضلا عن دلالته النّفسية فهو يحمل دلالة فنية تكمن

في تحقيق النغمة، مما يضفي على النص قدرة كبيرة في التأثير على القارئ.

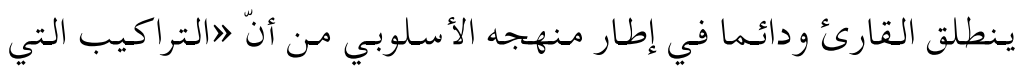

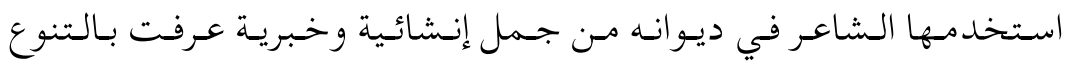
والإِثراء، وكانت كل لفظة من ألفاظ الديوان حاملة لد لالات سو اء كانت 
هذه الألفاظ أفعالا أو أسماء«15 بناء على ما سبت يمكن القول أنّ القارىء "نبيل لنصاب" في قراءته هذه نظر إلى النّص الشّعري نظرة أسلوبية، وأظهر استراتيجية الشّاعر في الكتابة.

\section{2- 3 قر اءة نسيمة رحال :}

أشـارت هذه القارئة في دراستها إلى تجـليات الرمز الصوفي في الديوان؛

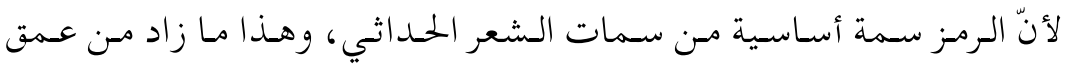
التجربـة الشعريـة الحمداثية وغموضها إذ لايعبر عن معنى غير معلوم مسببقا،

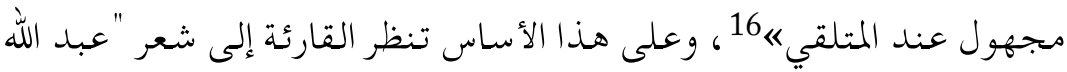
حمادي" مـن حيث اللغة أنّها تشبه لغة الصوفي؛ لأن لغتهما تختلف عن لغة العامة هي 》لغة الغموض لا لغة العموم لغة المجاز والرمز، لا لغة التصريح والوضوح"17 ولغة الشاعر هي لغة الكشف والتجاوز، و ومثال ذلك شرحها لقوله:

$$
\begin{aligned}
& \text { إمامي لا تَمننْ بالخرقة والكوز } \\
& \text { أنت نـور الأقـطاب } \\
& \text { والأيسن المعسروف }
\end{aligned}
$$

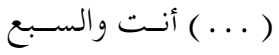

$$
\begin{aligned}
& \text { مسدارات } \\
& \text { وروح الـروُّح } \\
& \text { ومـا دون الملْفــوظ ... } 18
\end{aligned}
$$

إذ ترى أنّ الشّاعر الصوفي يكشف عن عالم الألوهية، وأنّ كل ما يكشفه

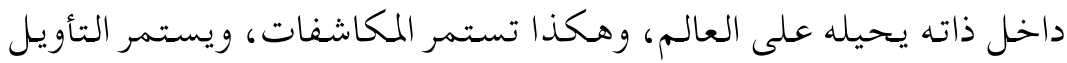


إلى ما لانهاية من أجل إدراك حقيقة العالم الروحي 19.

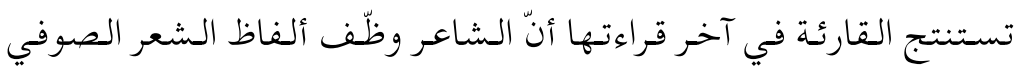

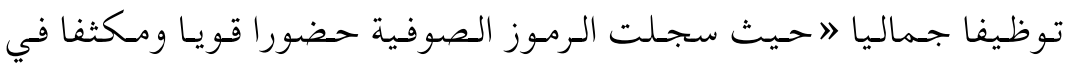

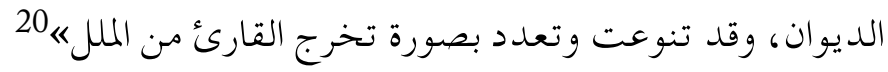

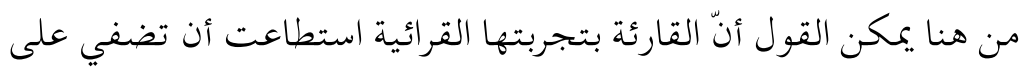

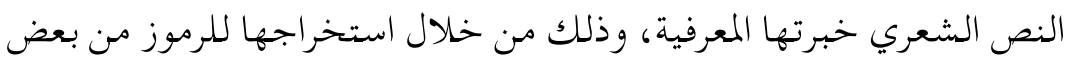

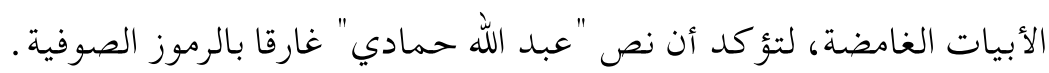

\section{2-2 - 2 قر اءة عبد الغاني خشة :}

ركّز القارئ في قراءتـه عـلى غـلاف الـديـوان، بمـا يحسمله مـن أيـقونـات ومكونات لغوية، باعتبارها نصا مصاحبا للنص الشعري، محاولا استنطاقها

$$
\text { للوصول إلى دلالات النصوص الشعرية. }
$$

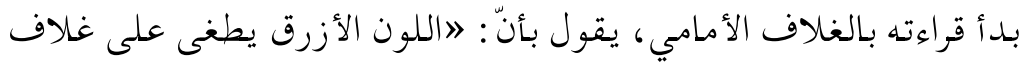

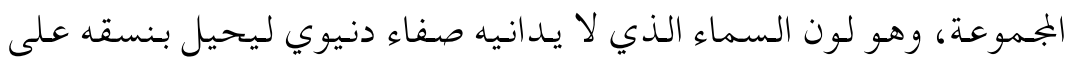

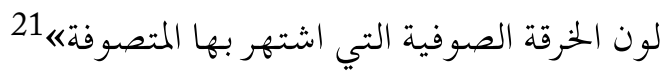

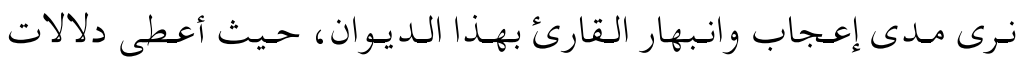
لغلافه انطلاقا من قاعدة موضوعية، فالسماء معروفة بصفاءها، وهذا التأويل

$$
\text { الإِيجابي ربطه بحال المتصوفة. }
$$

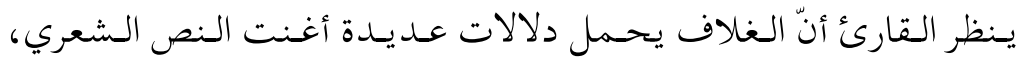

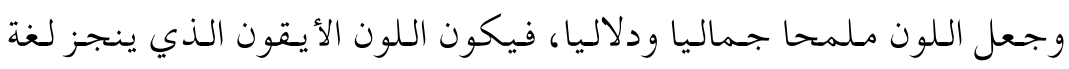
جديدة تتحدث عن الموضوع المطروح.

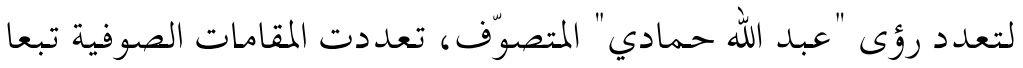


له،بمعنى أن الغلاف كان مفتاحا ولج من خلاله الشاعر عالما أرحبب ينفتح على طقسية متعددة الرؤى تنتمي إلى عالم مغاير22.

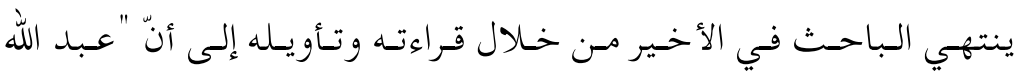
حمادي" شاعر متصوف.

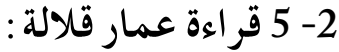

تطرق القارئ لسيمياء العنوان "ستر الستور "، فرأى لهذا العنوان دلالتين، دلالة معجـمية، ودلالـة إيـائية، تـقوي إحــاهـما الأخـرى وأن نظير السّتر

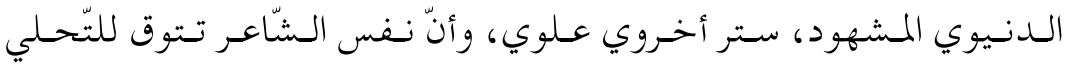
والتّجلي 23.

يذهبب أيضا بأنّ الشّاعر استعمل ألفاظا صوفية مثل : الهوى، احتجابي،

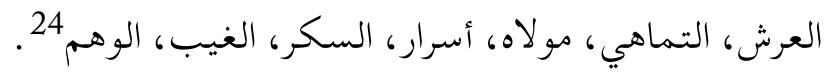

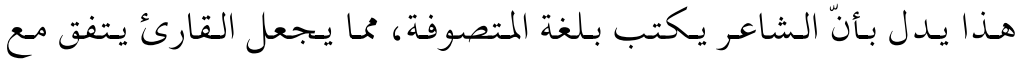

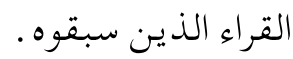
كما عرض للتّاص، حيث الشاعر استحضر نصوصا أخرى في قصيدته

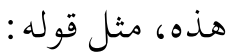

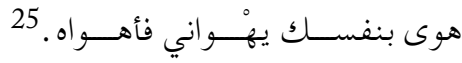

$$
\text { تناص مأخوذ من قول الباخرزي: }
$$

وشادن ليس يَهْوَان وأهُوْواه و والمستعان على هجرته الله.

يقر أنّ طريـقة الشّاعر في تعمية النّصوص المستحضرة مثار للعجبب، ينتشي القارئ بكشف نقابها وهتك حجابها 27. 
كانت قراءة هذا الباحثث بمنظور سيميائي؛ بـدأ بالعنو ان ثم مـتن النّص، وصل إلى دلالة مفادها بأنّه يزخر بالمعاني الصّّوفية.

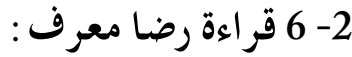

هـذه القراءة بـدورها أعربت عن مضمون القصيدة، إذ تنطلق مـن فكرة

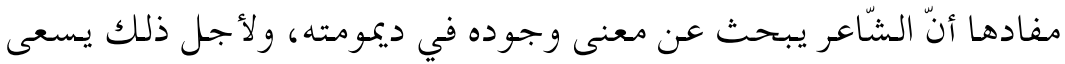

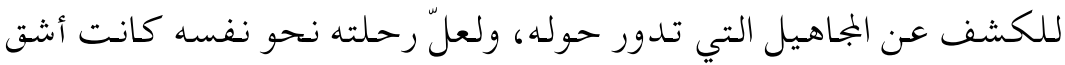

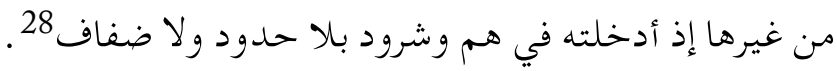

$$
\begin{aligned}
& \text { يسـاور النَّفْس } \\
& \text { هم لا ضفاف لَه } \\
& \text { هو الشرود الذي ما دونه } \\
& \text { أَمـلـ } 29
\end{aligned}
$$

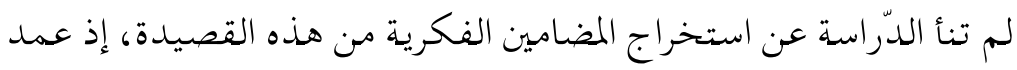

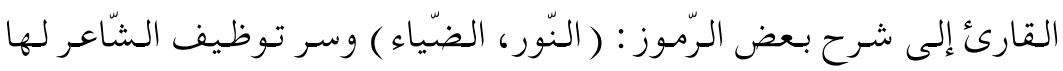

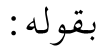

$$
\begin{aligned}
& \text { وما احْتَجـابي } \\
& \text { وَرَاءَ النور إلآهوَى } 30 \\
& \text { وفِي التَّرَجِّي } \\
& \text { ضيَـاءُ } \\
& \text { يستضـاءُ به } 31
\end{aligned}
$$

يرى القارئ أنّ الشّاعر بتوظيفه للضّياء يريد أن يكشف عن الموجودات وعن حقيقتها المظهرية التي يمكن للعين أن تبصرهاكئ. 
يصل إلى أنّ الشّاعر لا يكتفي بالمعرفة الوضعية، عقلانية أوتجريبية، وإنّا

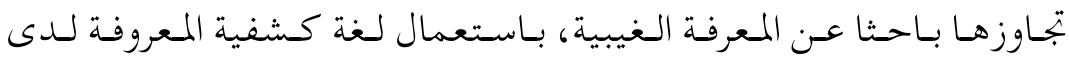

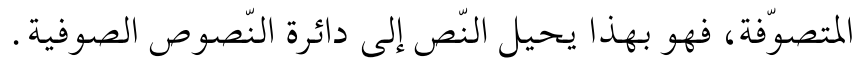

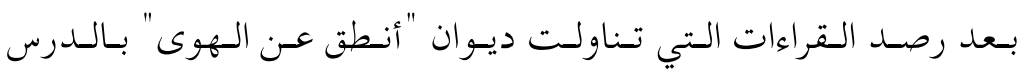
والتحليل، حيث تباينت في أشياء وتشابهت في أشياء أخرى، وعلى الرغم

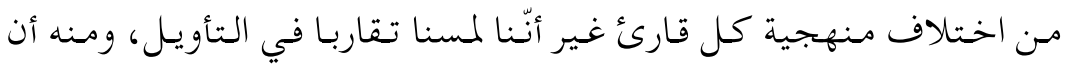

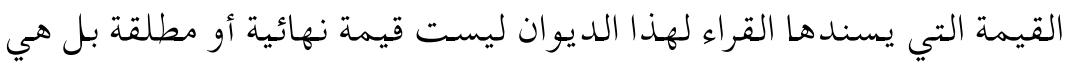
عرضة للتغيير والتعديل باستمرار،بناء على تغير ظروف وثقافة القارئ.

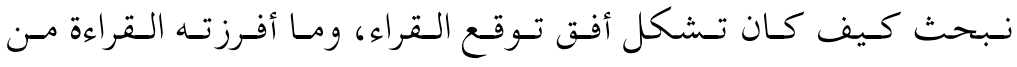
جماليات يتخللها كسر في أفق التوقع. 3- أفق التوقع :

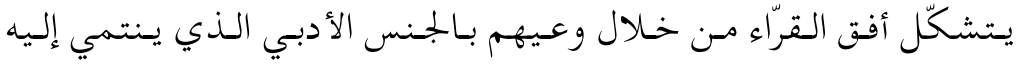

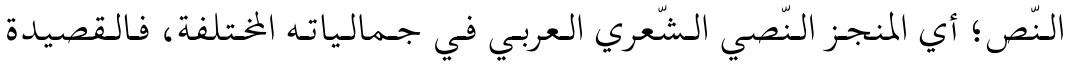
العربية تطوّرت عبر حقبات تاريخية، لكنّها كانت تحرص على ملائمة أذواق

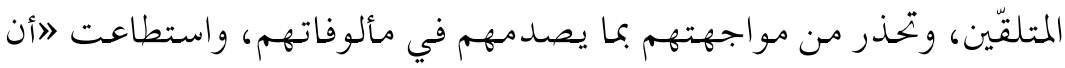

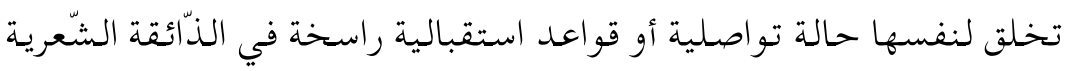

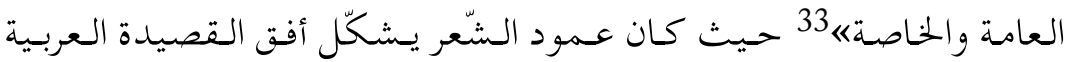

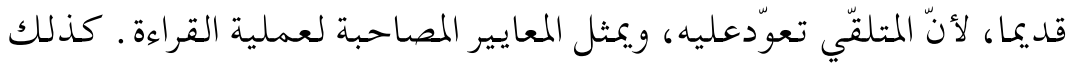

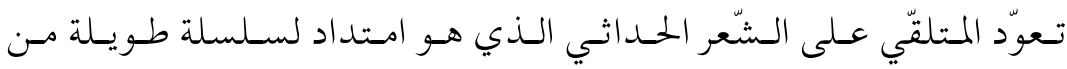
إبداعات السّلف وفي الوقت نفسه هو انفصال عنه. 
انطلاقـا مـن هـذه الأفكار، يـكون قـد تشكّل للـمتلقّي أفق توقّع معينّ

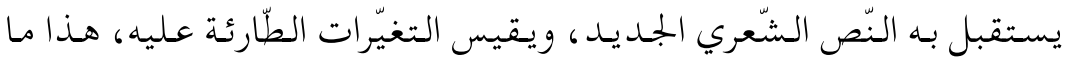
يسمى بالمسافة الجمالية، لأنّها تفصل بين الأفق الموجود سلفاو الأفق الذي

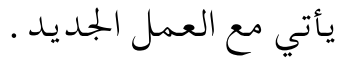

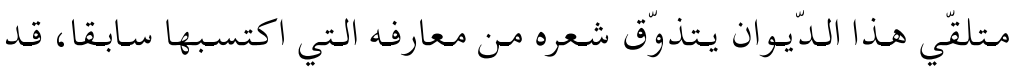

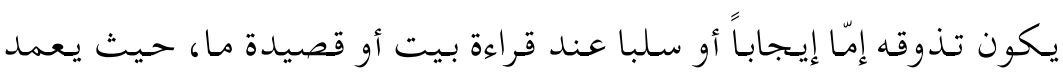
الققارئ للبيت أو القصيدة إلى الاحتـكام لمخزونه الشّّعري لـيقارن مـدى تميّز

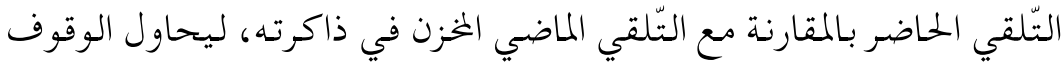
عند الأفضلية لهذا البيت أو القصيدة بين كل مـا تلقاه مس قبل، وإذا كان

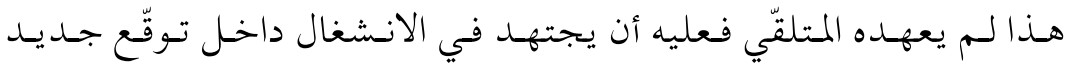

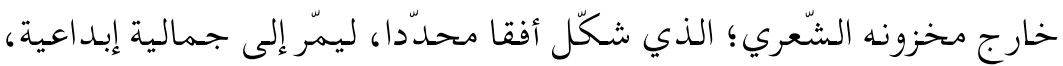

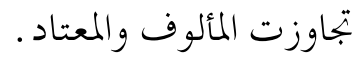

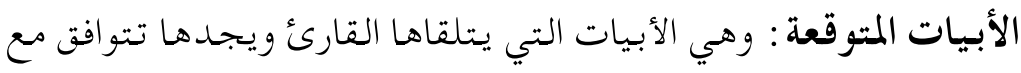
ذاكرته الشّعرية، مثال ذلك كما جاء في الأبيات الآتية : من قصيدة "قصيد

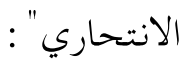

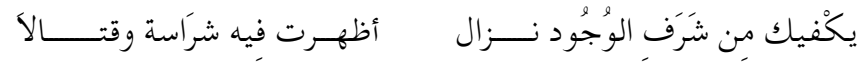

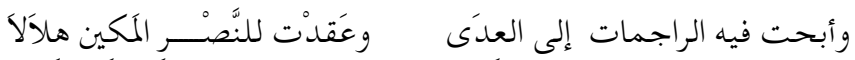

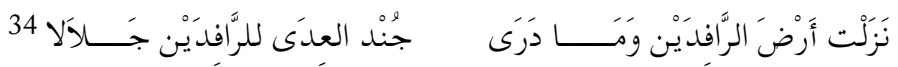

في هذه الأبيات لا توجد غرابة، حيث كتبها الشاعر على منوال الشعر العربي، وما تعارف عليه من قواعد في النظم، وفي هذا يقول القارئ "نبيل 
لنصاب" : "القد اعتمد الشّاعر على قافية موحمدة في كامل هذه القصيدة معتمدا في ذلك على نمط القافية التقليديةه 35 كذلك من الأبيات التي جاءت في هذا الديوان، ووافقت ما تعارف عليه المتلقيّ، وما وافق ثقافة مجتمعه وفكره، من ذلك قول الشاعر:

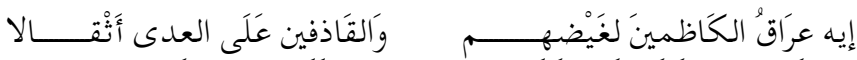

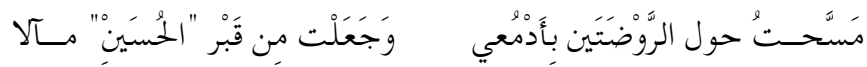

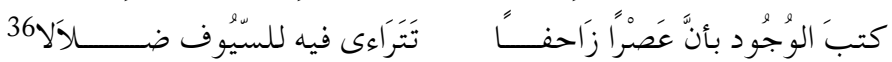

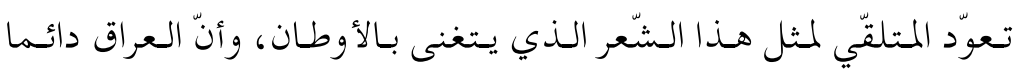

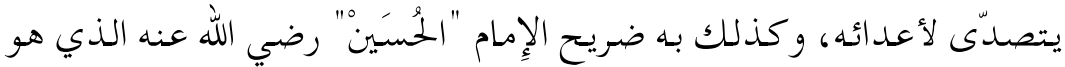
مزار لمبيده، وبالتالي هذه الأبيات بلدورها تستجيب لأفت توقعه . الأبيات المتوقعة أيضا قوله :

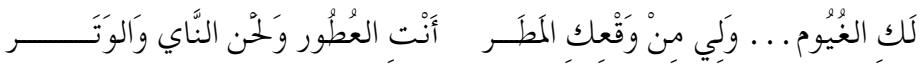

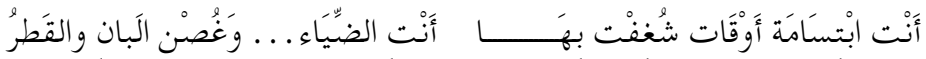
$37^{\prime}$

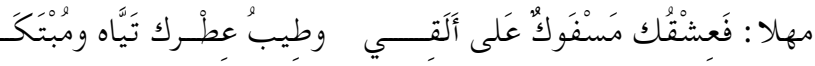

هـنا تجسيد للمعاني القديمة التي عني بـها شعراء الغزل، و كيف عالجوا الهجر والغرام والعشق، بهذا تقول القارئة "نسيمة رحال : لاقد جرى التغزل

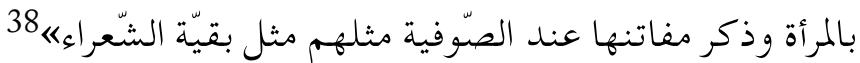

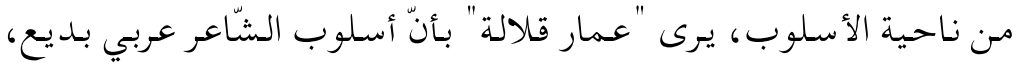
جمع فيه بين جـراءة الأسـد، ورقّة الحمل الوديسع، فالرقة تكمن في الناحية الإِيقاعية، وأمّا الجراءة في بنية العنوان39؛ أي أنّ هذه الكتابة متوقِّة مألوفة 
في شـعرنـا العربي، مـوجـودة في أفق المـلقِّي، لأنّ لالـشّاعر الـتزم المسـلك

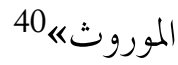

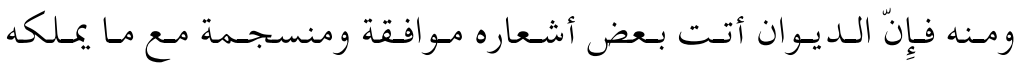
المتلقي من موروث شعري، فأرضت توقعه لعدم تميزها عن غيرها من الشعر العربي.

\section{4- كسر أفتق التّوقع : ك}

هو أن يخرج النّص الشّعري عن الصّيغ المتعارف عليها، وطرائق التّعبير الموضوعة، تجاوز لما تتعاطاه التّجارب السّابقة فيحدث من خلاله خيبة لدى القارئ ( كسر أفقه )، ويفسح له مجالا لتعدد القراءات والتأويلات .

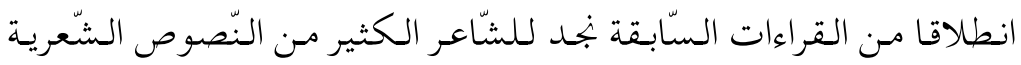

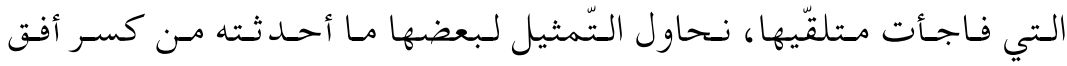

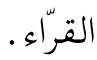

يقول "محمد كعوان" معلقًا على هذا المقطع:

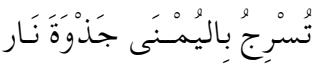

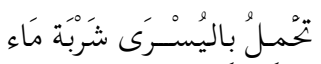

$$
\begin{aligned}
& \text { تُشْعِل بِالنَّارِ الجَنَّة } 41
\end{aligned}
$$

بـأنّ الشّاعر لقام بفعل الصِّدم والمشاكسة الدلالية، فهذا العدول الدلالي

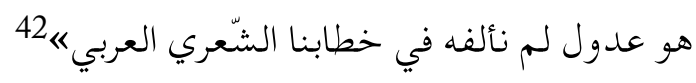

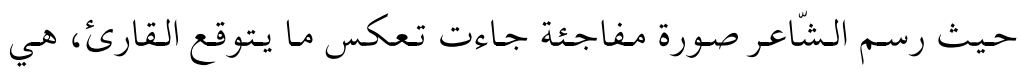

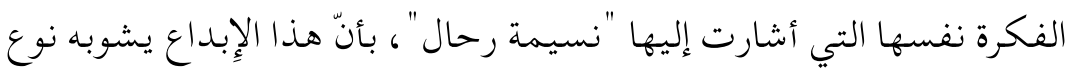




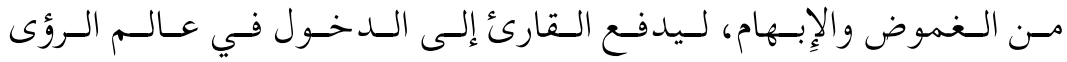
والتخيلات

الغموض الذي هو ميزة، يتحول إلى كسر في أفق التوقع، فيقرأ على أنّه

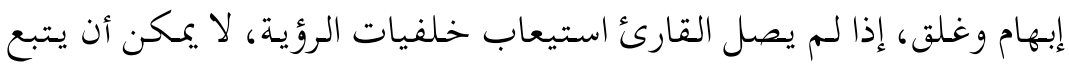
الدلالة ويجتهد في التأويل .

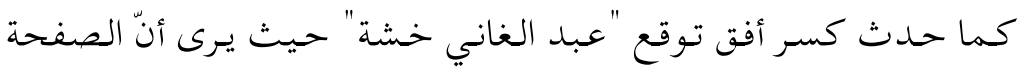
الأخيرة من الغلاف جاء مشفوعة بمقبوس شعري من المجموعة، وينتهي هذا المقبوس بثلاث نقاط، إنّا تجاوز به الشاعر المألوف ليفسح المجال أمام المتلقي

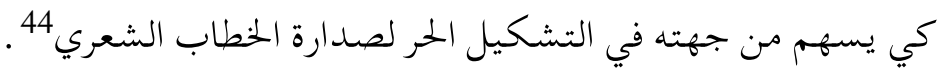

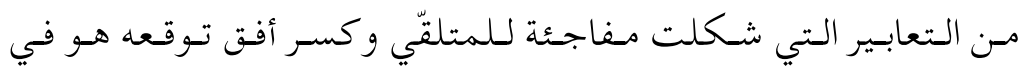

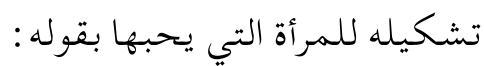

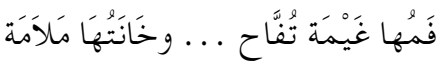

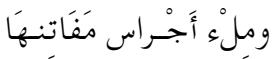

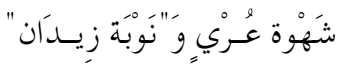

$$
\begin{aligned}
& \text { مُعَعَقَة عَلى وَتَّر القيَّامَة . } 45
\end{aligned}
$$

ساهمت نصوص هذا الشاعر بشكل أو بآخر في كسر أفق المتلقي، فوجئ عند قراءته لهذه النصوص يجدد بعضها استثمر آليات النثر كقول الشاعر:

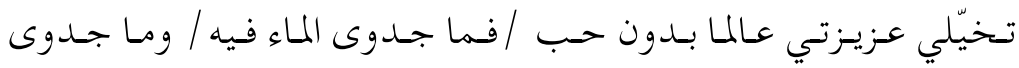

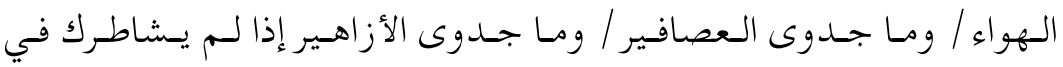

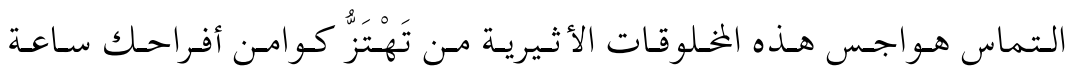

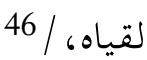


إذا مـا قرأنـا هذا نقول أنّه كلام مباشر، اعتمد الإِبلاغ والتواصل المباشر

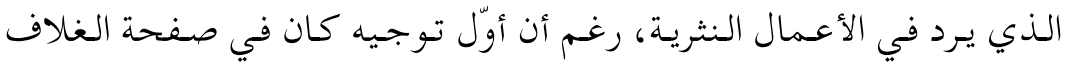

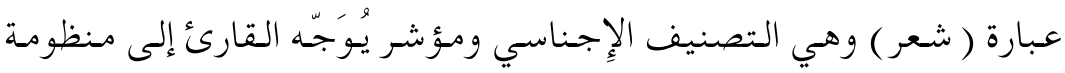

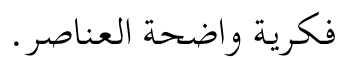

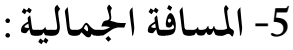

انطلاقا من آفاق القرّاء وأفق النّص الشّعري، تقاس المسافة الجمالية، التي تعتمد على مدى توافق أو تعارض النّص مع الأفق السّائد .

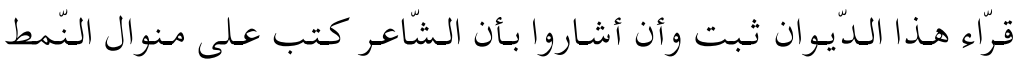
التقليدي في بعض نصوصه الشّعريـة، والذي اعتاده الذوق الأدبي والمعيار

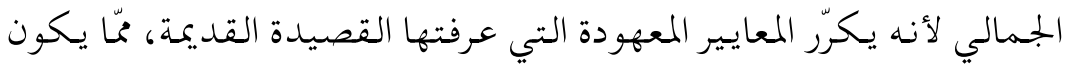

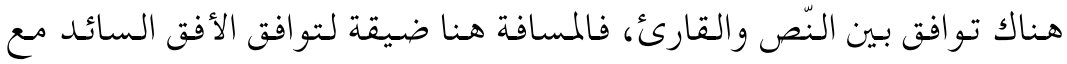

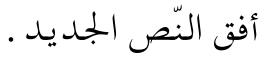

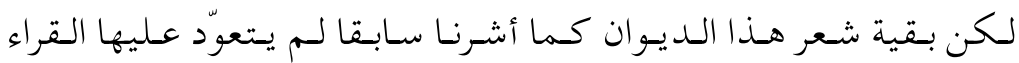

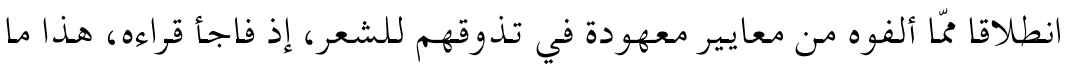

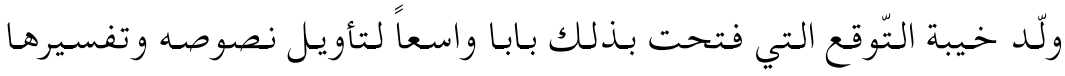
رغبة في الوصول إلى جمالياتها، ومنه اتسعت مسافتها الجمالية .

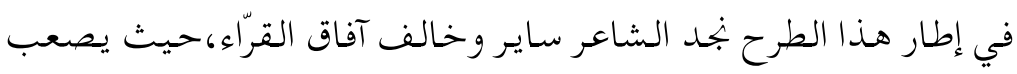
قياس المسافة الجمالية لكل النصوص دفعة واحدة، وأيضا شعره قد يوافق أفق

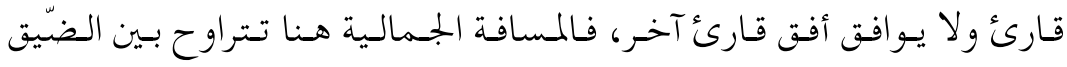
والاتساع مما يتعذر قياسها . 


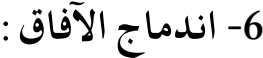

إنّ اندماج أفاق القرّاء في أفق واحد شكلته تلك القناعة، بأنّ شعر "عبد

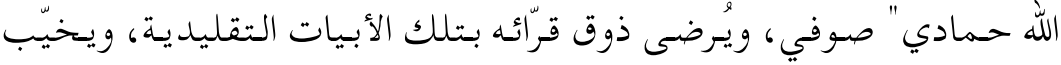
أفاق انتظارهم بالأبيات التي تنتمي إلى الشعر الحمداثي، التي تَعْمَدُ إلى كسر أفقهم بما تحتويه من انزياحات وصور خيالية بعيدة عن الواقع، كما يتفقون

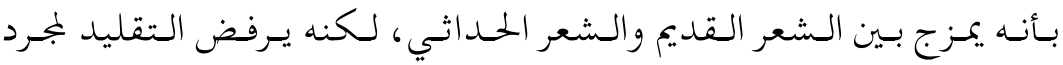

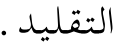

من هنا يدخل أفق القارئ الحاضر مع آفاق القرّاء الذين سبقوه في حوار معهم من أجل فهم النص، وتعديل قيمته ومعناه من جهة ثانية.

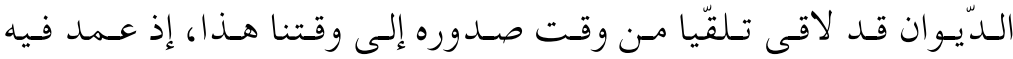

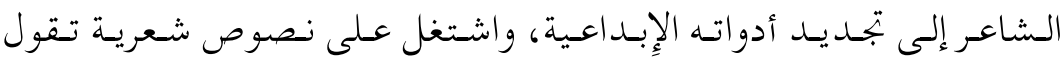

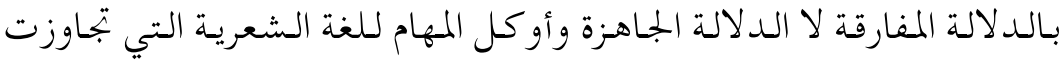
مرجعها وما اقترنت به من غموض وفنون السحر ولا سيما اقترانها بالتصوف وتداخلها بمعاني التحول الارتقائي اللامتناهي وبلوغ الجوهري. وهذا ما جاءت به قراءات ديوان التي كانت متشابهة في بعض الأحيان إذ

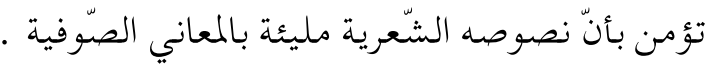

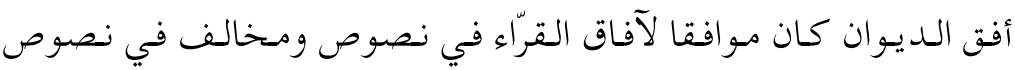
أخـرى، حسيث أن بـلاغـة الـديـوان هي التي فرضـت نفسها عـلى القارىئ،

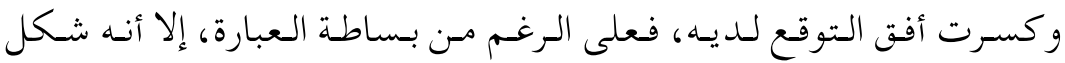
صـدمـة لـلقارئ، وأزاح الـنقاب عـبر الكتابـة عن بـعض الأسـرار والمكونـات 


\section{والكشوفات التي جعلت مـن الشاعر "عبد الله حمادي" واحـدا من أجمل شعرائنا المعاصرين.}

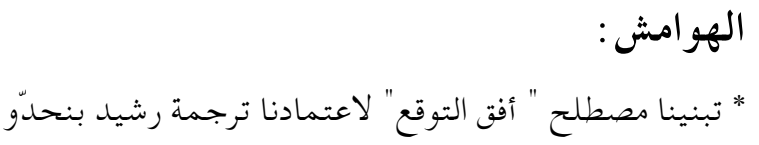
1 عبد الكريم شرفي : من فلسفات التأويل إلى نظريات القراءة، الدار العربية للعلوم، بيروت، لبنان، ط 1، 2007، ص 162. 2 بشرى موسى صالح: نظرية التلقي أصول وتطبيقات، المركز الثقافي العربي، دار

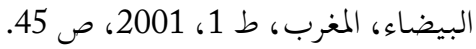

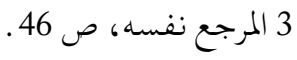
4 ناظم عودة : الأصول العرفية لنظرية التلقي، دار الشروق للنشر والتوزيع، عمان،

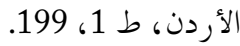
5 روبرت هولب : نظرية التلقي، تر : عز الدين إسماعيل، المكتبة الأكاديمية، القاهرة،

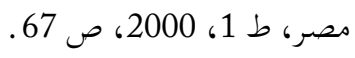

6 عبد الرحمان تبرماسين وآخرون : نظرية القراءة المفهوم والإجراء، منشورات مخبر

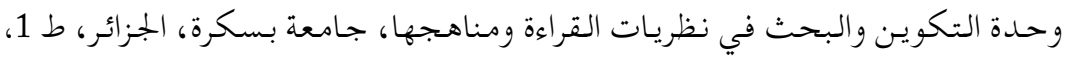

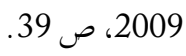
7 أسامة عميرات : نظريـة التلقي النقديـة وإجراءاتها التطبيقية،في النقد العربي

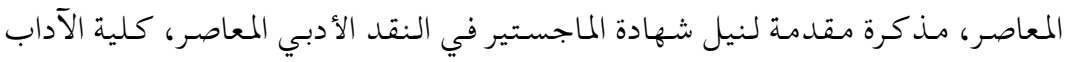
واللغات، قسم اللغة العربية، جامعة الحاج لخضر، باتنة، 2010-2011، ص 53. 
8 السعيد الورقي: مقالات في النقد الأدبي، دار المعرفة الجامعية، مصر، [ د ط]]، 2003، ص 7

9 محمد كعوان : التأويل وخطاب الرمز، قراءة في الخطاب الشعري الصوفي العربي

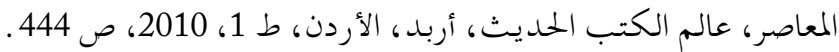

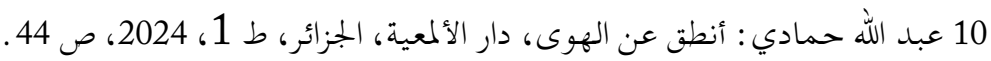
11 محمد كعوان : التأويل وخطاب الرمز، ص 145

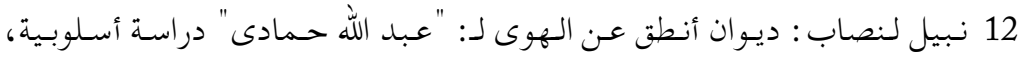

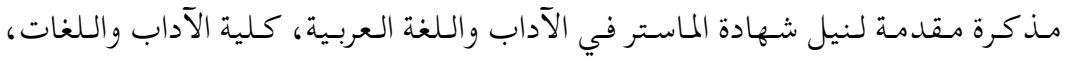
جامعة محمد خيضر، بسكرة، 2013/2012، ص 52. 13 ينظر: المرجع نفسه، ص 62. 14 الديوان، ص 19 15 نبيل لـنصاب : ديـوان أنطق عـن الهوى لـ: "عبد الله حسمادى" دراسـة أسـلوبية، ص 114.

16 فرجد تابتي : الرمز في الشعر الجزائري المعاصر، نقلا عن : نسيمة رحال، تجليات

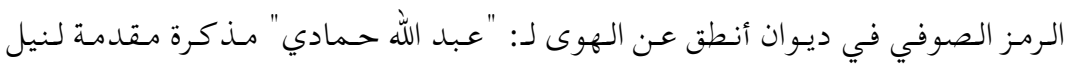

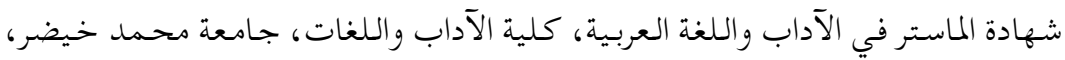

$$
\text { بسكرة، } 17 \text { المرجع نفسه، ص 2013/2012. ص } 9 .
$$$$
18 \text { الديوان، ص } 53 .
$$

19 نسيمة رحسال : تجـليات الرمز الصوفي في ديوان أنطق عن الهوى لـ: "عبد الله

$$
\text { حمادي"، ص } 20 \text { المرجع نفسه، ص } 94
$$


21 عبد الغاني خشة :'الخطاب الغلافي ومضمرات التصوف في أنطق عن الهوى"

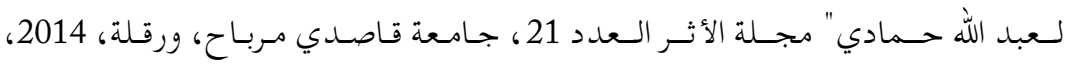
ص 114.

22 يـظر : عبد الغاني خشة :'الخطاب الغلافي ومضمرات التصوف في أنطق عن الهوى" لعبد الله حمادي" ص 115.

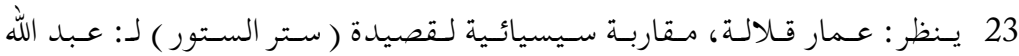

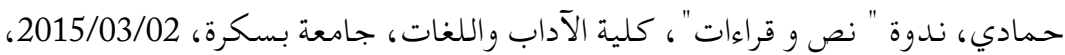
ص 4. 24 ينظر : المرجع السابق، ص 6. 25 الد يوان، ص 55.

26 موقع: بوابة الشعراء، شعر الباخرزي، نقلا عن: عمار قلالة، المرجع السابق، .8 27 يـنظر : عسمار قــلالـة، مـقاربـة سـيسيائية لـقصيدة ( سـتر السـتور ) لـ: عـبد الله حمادي، ص 9. 28 يـظر : رضـا معرف، الذات والوجود في قصيدة ستر الستور لعبد الله حسمادى، ندوة "نص وقراءات"، كلية الآداب واللغات، جامعة بسكرة، 2015/03/02، ص صعردئ 1.

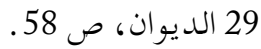

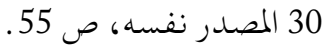
31 المصدر نفسه، ص 60.

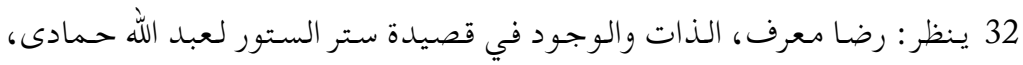
ص 4. 33 علوي الهاشمي : فلسفة الإِيقاع في الشعر العربي، دار فارس، عمان، الأردن، ط

$$
\text { 14، } 34 \text { الديوان، ص } 1005 \text { ص صل } 119 .
$$


35 نبيل لنصاب : ديـوان أنطق عـن الهوى لـ: "عبد الله حسمادى" دراسـة أسـلوبية، .55 36 الديوان، ص 121 (ان 127 37 الديوان، ص 63. 38 نسـيمة رحسال : تجـليات الرمز الصوفي في ديوان أنطق عن الهوى لـ: "عبد الله حمادي، ص 74. 39 عمار قلالة : مقاربة سيميائية لقصيدة ستر الستور لعبد الله حمادي، ص 5. 40

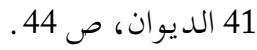
42 محمد كعوان : التأويل وخطاب الرمز، ص 445.

43 ينظر : نسيمة رحال، تجليات الرمز الصوفي في ديوان أنطق عن الهوى، ص 71. 44 ينظر : عبد الغاني خشه، الخطاب الغلافي ومضمرات التصوف في ديوان أنطق عن الهوى، ص الت 121. 45 الديوان، ص 72. 46 المصدر نفسه، ص 83. 


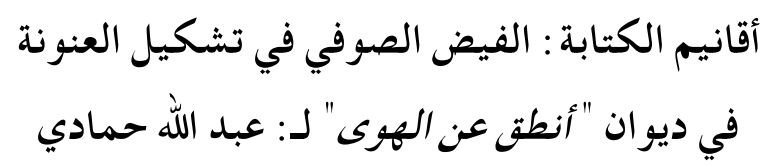

MODOS DE ESCRITURA: LA INFLUENCIA SUFÍ EN LA TITULACIÓN DEL DIVÁN ANTIQU 'AN AL-HAWÀ DE ABDALLAH HAMMADI

\author{
روفيا بوغنوط \\ جامعة العربي بن مهيدي ـ أم البواقي الجزائر \\ Rofia Boughanout \\ Universidad Larbi Ben Mahidi - Oum El Bouaghi
}

\title{
Resumen:
}

Los paratextos son unos signos semióticos abiertos al análisis críticoliterario debido a la posesión de una autoridad discreta y clara ejercida sobre el texto y el lector. Éstos representan un pacto de lectura mediante una poesía visual que utiliza el texto para construir el significado del texto literario desde la representación de una cultura visual donde el texto poético establece la belleza de su sentido. Los paratextos son recursos literarios que añaden un carácter de modernidad a la producción poética. En este estudio pretendemos acercar estos conceptos a través de los paratextos analizados dentro del diván Antiqu'an al-hawà del poeta Abdallah Hammadi.

Palabras clave: Abdallah Hammadi, paratextos, semiótica, crítica literaria, sufismo.

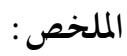

النصوص الموازية، علامات سيميائية قابلة للتأويل والمساءلة النقدية لما تمتلكه مـن

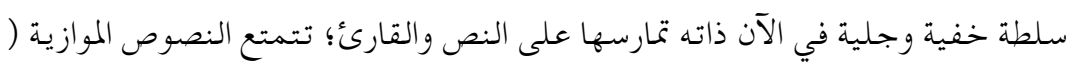
(le paratexte 


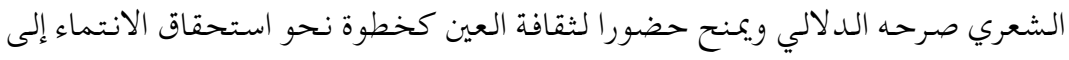
الحمداثة، وهو ما نرمي إلى مقاربته من خلال الوقوف على مجموع هذه النصوص الموازية في ديوان "أنطق عن الهوى" للشاعر عبد الله حمادي. مفاتيح البحثث : عبدلله حسمادي؛ النصوص الموازيـة؛ السيميائية؛ الـنقد الأدبـي؛ التصوف .

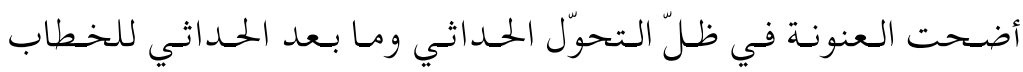

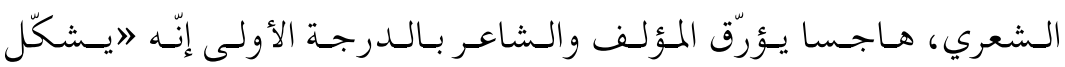

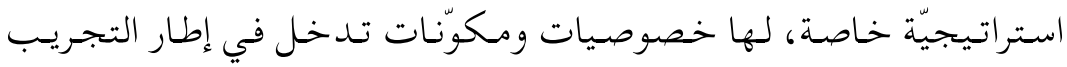
انطلاقـا مـن استفادتها مـن الركام الكالسـيكي مـن جهة ثمّ الوعي بـأهمية العنوان وتغيراته من جهة ثانية《1

وبناء على ذلك اختلفت قيمة العنونة في الخطاب، فلم يعد مرشدا لنا أن نـتعد اه إلى غـيره بـل لاحـلقة أسـاسـية ضـمن حسلقات الـبناء الإِسـتراتـيجي

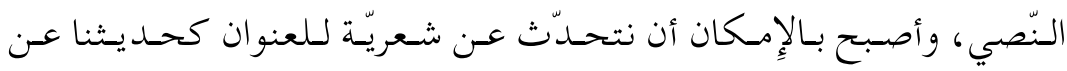
شعريّة النّصوص المعروضة بعد العنوانهُ2، فِإذا كان 》العمل بعلاماته اللغوية المتعدد دة وقو اعـده الـتركيبية المتنوعـة يـعتبر مـن جهـة إنـتاجيّة الـدّلالمة بمثنابـة "عالمة مفردة" ؛ فبـإمكاننا القول إنّ العنوان يشكل إنتاجية لاعلى الرغم من ضآلة عدد علاماته واشتغال قاعدة تركيب واحدة غالبا في تنسيقها تجعلنا نعده بمثابة عمل نوعي״3.3. يتجلى العنوان بمستوياته الخختلفة أهمّ وأخطر العتبات النّصيّة يهـب النّص حضوره وكينونته بـتسميته وإخراجـه من فضاء المُغفل إلى فضاء معلوم ، إنّ 
النّص لا يكتسبب الكينونة ويحوزها في ( العالم ) إلآ بالعنونة، هذا الحمدث

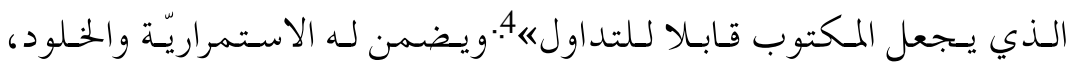

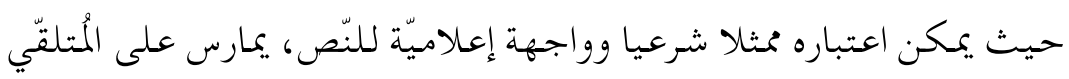

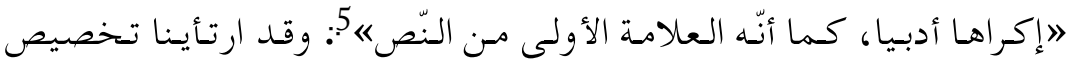
الحمديث عن جماليات العتبة النصية من خلال ديوان شعري لشاعر جزائري

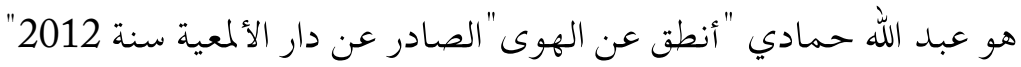

\section{1 ـ فائض الهوى في العنون "أنطق عن الهوى"}

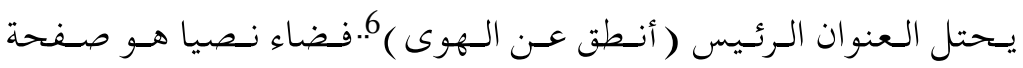
الغلاف، ما يجعل منه مركز نظم فاعل داخل الصفحة ويمثل الوسيلة الأولى

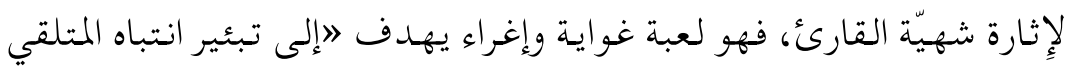

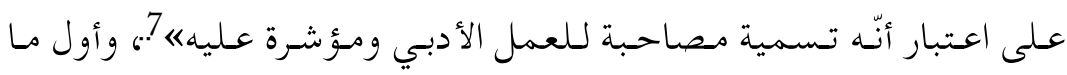
يسقدم عـليه عـنوان أنطق عن الهوى تيبئير انتباه القارىئ إلى مـا قيل سـابقا،

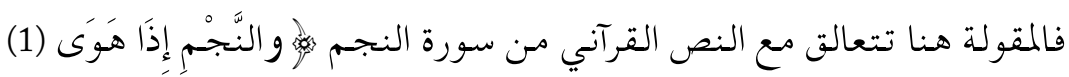

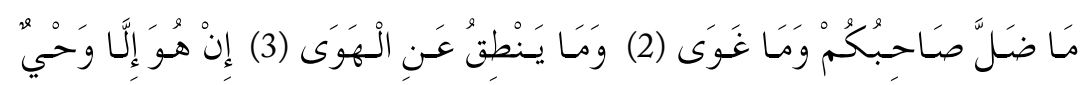

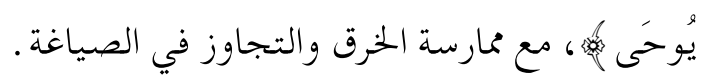

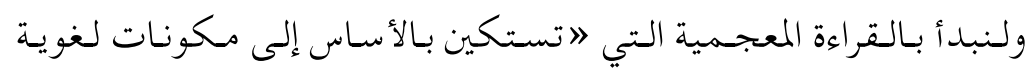
تضعنا في صلب القاموس مما يـجعل القراءة فعلا مـنحصرا في بـنية مغلقة

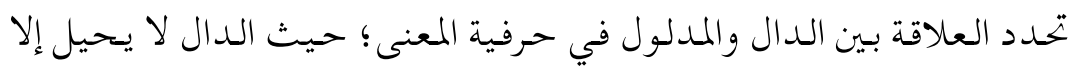

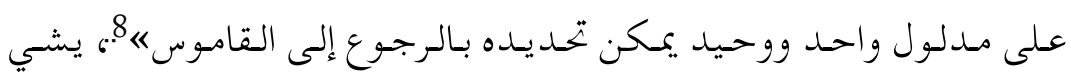

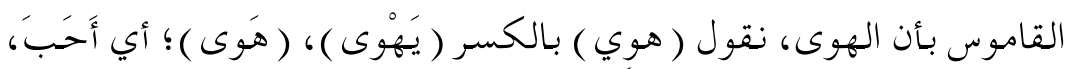




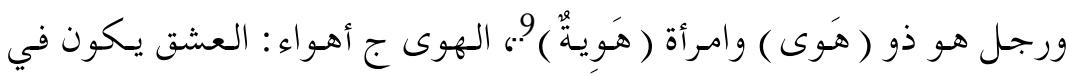

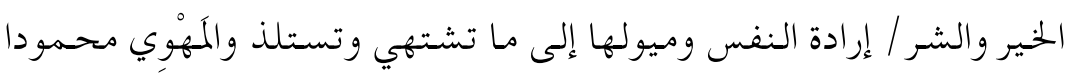

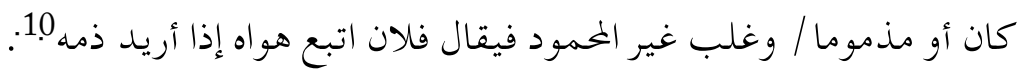

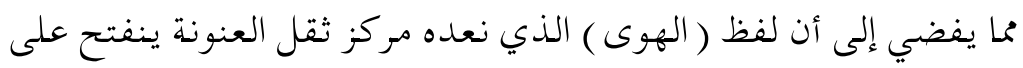

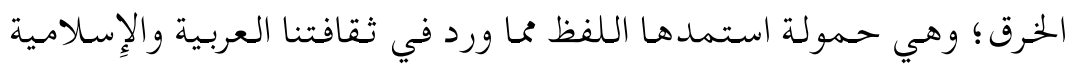

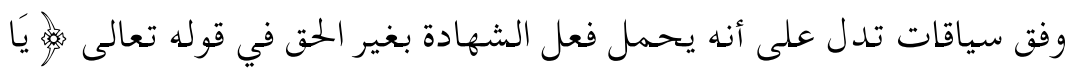

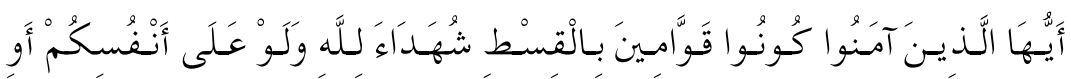

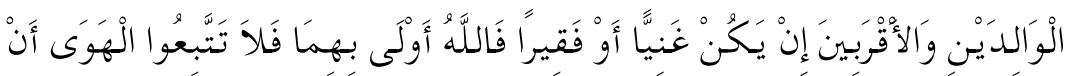

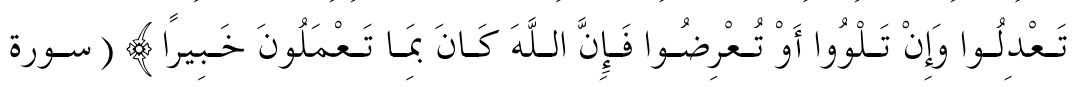

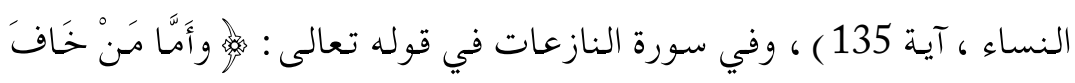

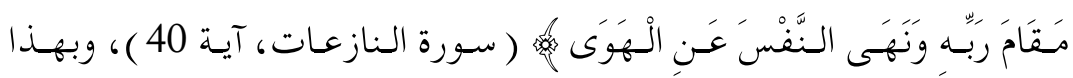

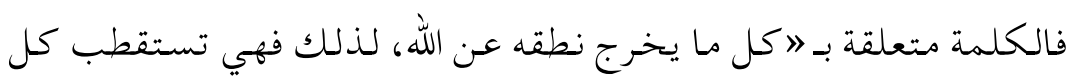
الصفات التي تحرض على ارتكاب الكبائر وإخماد جذوة الإِيمانهبن.

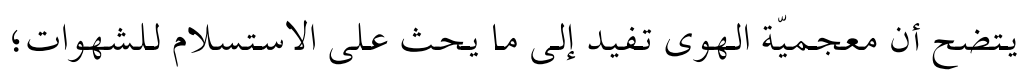

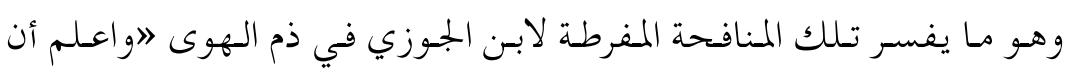

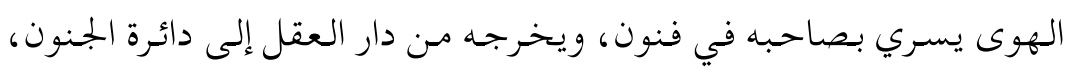

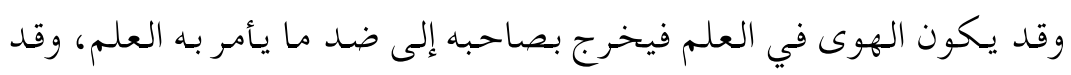

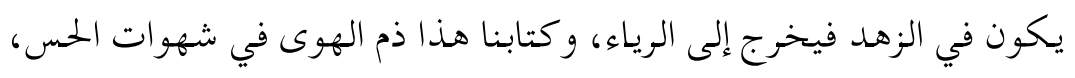

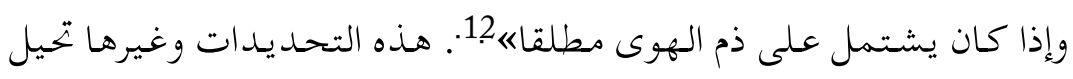

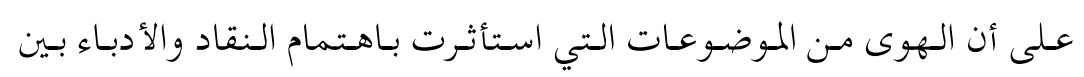

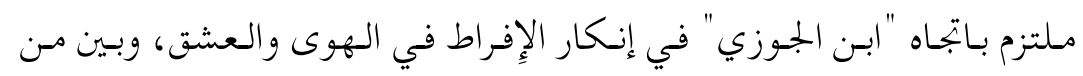


حسمّله بـعدا آخـر فـلم تـعد كـلمة الهوى تـتضمن مـا هـو مـندرج في بـاب الشهوات مطلقا، بل تشمل أيضا ما يجلب المصلحة للناس ويفيدهـم في هـي حسياتهم ( ... ) وما يـتعلق عـمومـا بـالأحساسيس والـعواطف (عـلى نـحو الفضيلة، الشرف، الغيرة، الحب، القوة. لنا أن نشير إلى بعض الكتب التي اتخذت ( الهوى، والحـب، والعشق )

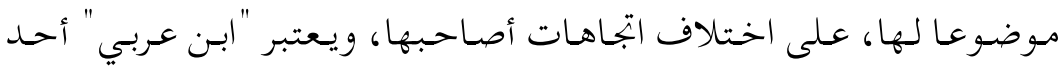

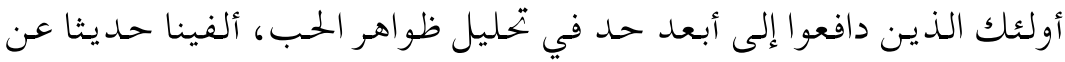
الحب والهوى في كتابه "الخبة والحب الإِلهي" حين يقول 13.

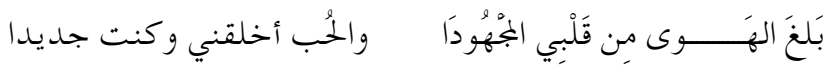

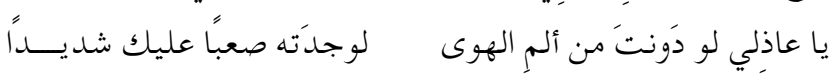

وقد نظر إلى وجـود نوعين مـن الهوى ، نوع أول قال عنه : سقوطه في القلب وهو ظهوره من الغيب إلى الشهادة في القلب، يقال : النجم إذا هوى

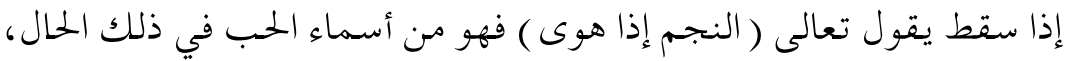

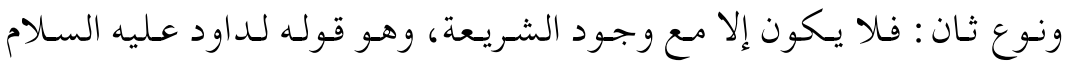

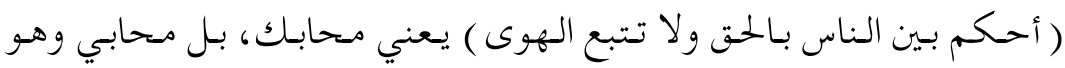

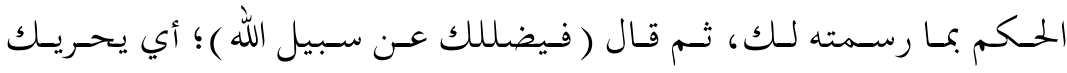

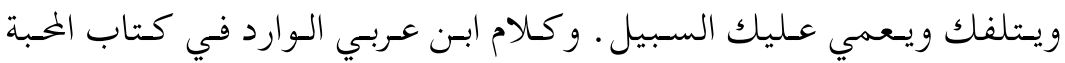

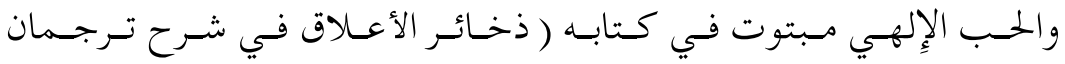
الأشواق )، ويـضر مـوضوع العشق والهوى في كثير مسن المؤلفات الأدبية الحمديثة والمعاصرة، من بينها كتاب زكي مبارك ( مـدامع العشاق ) والذي تهي 


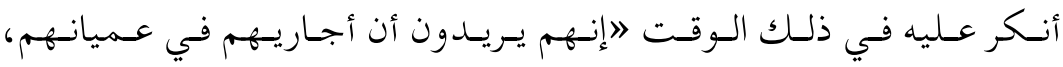
وأسايرهم في جهالتهم، فلا أكتب في غير ما يروقهم مس الدنيا، والتبرم

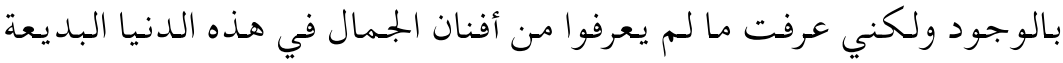

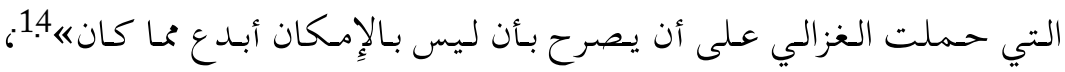

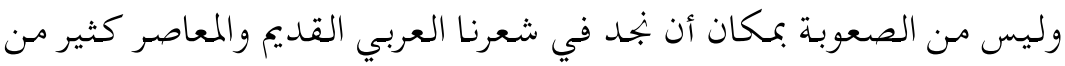

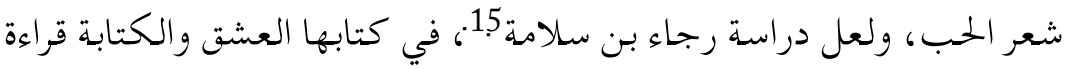
في الموروث، قد أحاطت بالموضوع؛ إذ فتحت عبر تركيبة العشق، والكتابة

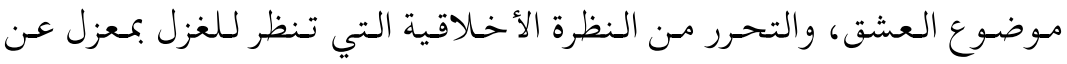

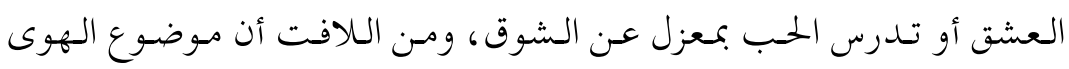
والعشق من المواضيع المثيرة وخصوصا حين يرتبط بمشايخ التصوف لالعبة الحبب الصوفي باعتباره تآمرا بين الروحاني والجسمهاني، تلك الطاقة المتخيلة

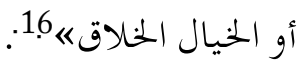

هي الطاقة المتخيلة أو لعبة الخلق المتخيل - كذلك - التي ينفتح عليها

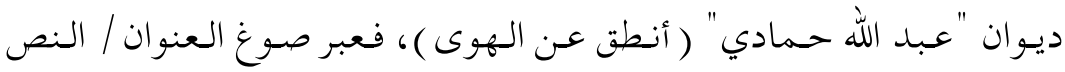
نـلفي ذاتـا تمارس فعلها المنشود، وهـو ( النطق ) تردفه بـلفظ ( الهوى ) منما

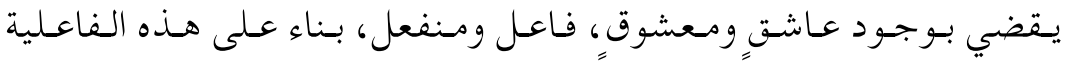

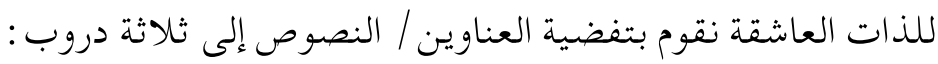
1 - (هوى ينفتح على النص / الكتابة ) فاعليته محملة بوجهة صوفية

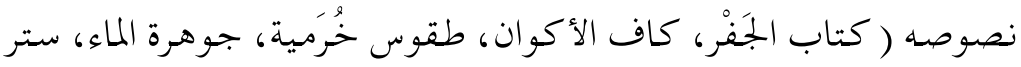
الستُتور، السؤال، أنطق عن الهوى ) . 
2 - (هوى امرأة) فاعليته محملة بعشق للأنثوي نصوصه ( الغواية،

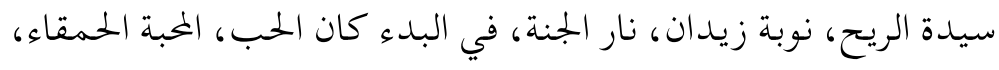
شعرها الليلكي ) . 3 - (هوى المكان ) موجهـ إلى الأمكنة نصوصه ( الشعر في أقبية الريح والزعفران، أندلس الأشواق، القصيد الانتحاري ). ليغدو بـذلك النطق ممارسة للفعل عن نية وسبق عشق؛ هي حال ذات

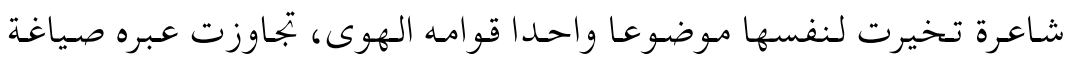

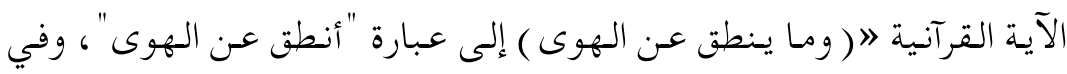

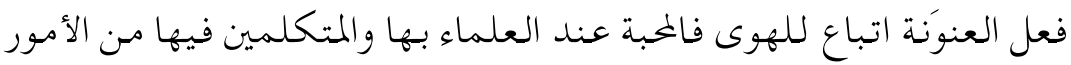

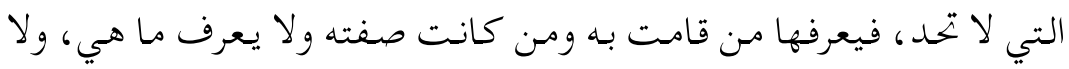

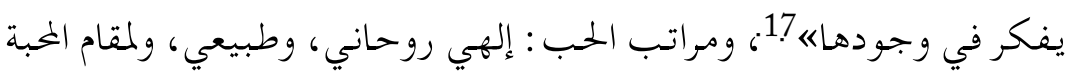

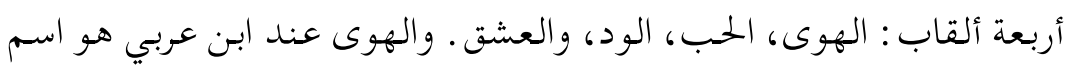

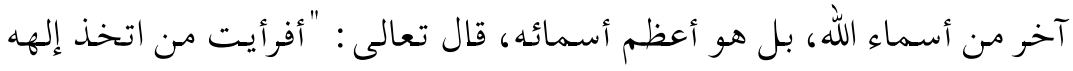

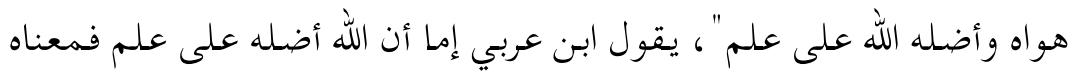

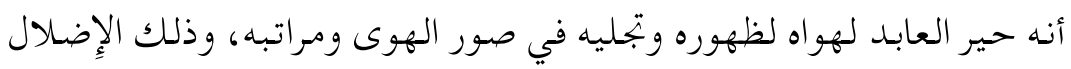

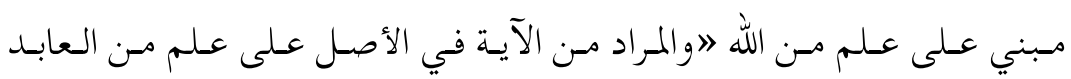

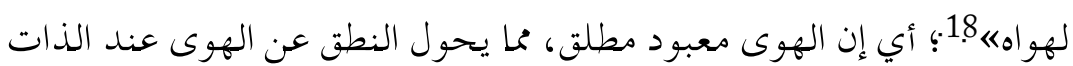
الشاعرة فعلا مطلقا لا يحده حد ممتد عبر فضاء النص، انفتاح باسم الكيان واللغة والأنثى ثالوث ينصهر في جوهر واحد هو النص.

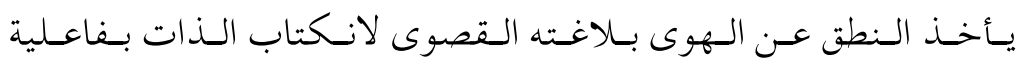
لانهائية؛ إرباك وخلخلة وتشظيات للاختلاف، بحث في المجهول لانهاية له، 
وُمهـدداً في الآن ذاته بغواية التأويل يقول :

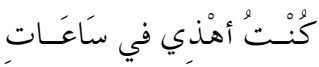

الفَجْرُ اللَيْلِية

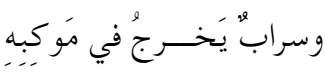

يَتقصى أثـرَ الموت

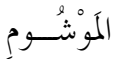

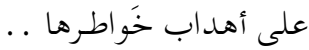

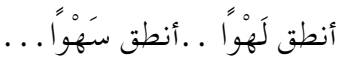

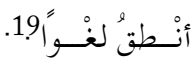

يحمل الفعل "أنطق" بكل مـا يـكتنز الذات الشاعرة مـ ميولات فكريـة ومذهبية تاريخية وعقائدية ، إخراج لمكنونات عبر ممارسة فعل النطق، هي ذات تفض الستر وتعلن أهواءها، تتكلم بحروف وكلمات تفضي بـدواخل الأنا، أو لنقل إنها ذات ترى في الكتابة فعل خلق، هو ما يشي بـه التصدير المعنونة ب "تنبيه الغافل " ، ليتحول المنطوق إلى مكتوب ينشـ الرغبة؛ الحق إنـها وجههة ارتـضتها الـذات السشاعـرة لـعبد حسمادي مسنذ ديسوانـه "الـبرزخ والسكين" ، مـانـحة للعملية الإبــداعية صـفة الكتابـة . لـقد وجـد "عـبد الله حمادي" في ابن عربي على وجـه التحديد يـ ممارسة نصية، قانون العبور إلى الحداثة العربية التي تقوم على ممارسة استباقية، منقطعة عن السائد ومندفعة جهة المجهول، هي بيانات كتابية كثيرا ما نافح عنها أدونيس ومحمد بنيس، صالح أمين وقاسم حداد. . مان. بهذا فالعنوان الشعري / أنطق عن الهوى \سيرورة ذهنية متحدة في الزمن 
ومتضمنة لسيرورة من البحث عن الدليل الإظظهاري الأكثر مناسبة للتأشير

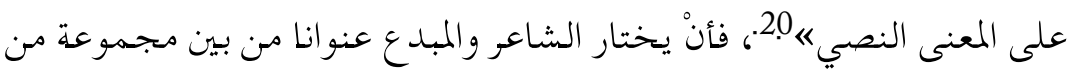

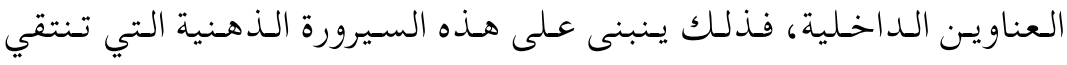
وتختار، لكن إلى أي حد يستطيع العنوان الختار من بين ثمانية عشر عنوانا

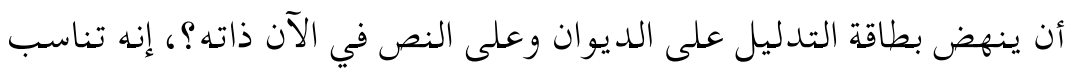
طردي في الدلالة يقضي بقدرة الكلمة / العنوان على الانتقال من الإِشارة على نص واحد إلى التأشير على مجموعة نصوص.

$$
\begin{aligned}
& \text { أَنْطقُ عَنْ الهَوى } \\
& \text { وهـوى مَحْبِّبِ } \\
& \text { يمْشِي فِي الطُرُقَّاتِ }
\end{aligned}
$$

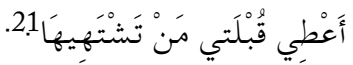

النطق فعل حركي قصدي من الذات، ينضاف إليه أنه صادر عن هوى

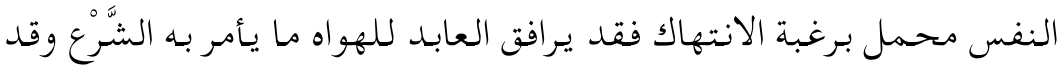
يخالفه ويتبع الشهوة يقول :

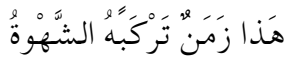

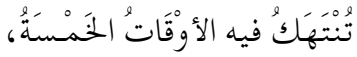

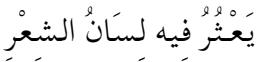

$$
\begin{aligned}
& \text { فِي ذَيْلِ عَبَّاتَّهـ ... }
\end{aligned}
$$

تتقصد الذات -هنا- الخروج وإعلان الحب أنى توجهت، وقولنا بالخروج

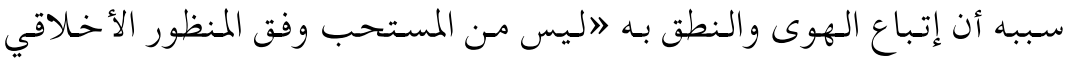

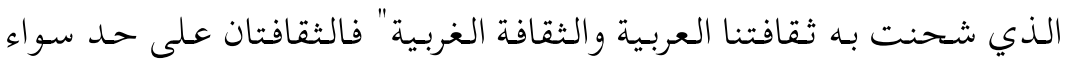


تشجبان تحيين الأهواء لخطورتها على العقل «23، والهوى في الديوان يحركه

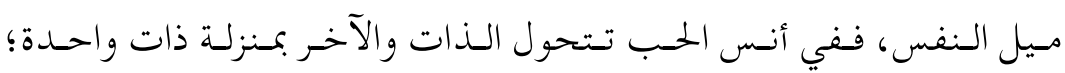
تنصهر الأنا بكل قصدية في افتراس الأخر اشتهاء وشغفا، ويتجلى التفاعل بين اللامرئي والمرئي، بين الرُوحَاني والجِسماني، حضور للفاعل والمنفعل إنها الصورة الإِنسانية المحملة بقوة روحانية حقيقية لاقوة خلاقة .فهي التي تخلق الحـب في الإِنسان ،وتوقظ في نفسه الحـنين الذي يقوده إلى ما وراء مظهره المسوس، هي التي تقوده إلى معرفة ذاته، أي معرفة ربه《24.، يقول :

هَوَى بَنَفْسَكَ

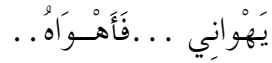

وَطَيْف عَرْشِـــكَ يَلْقَانِي

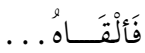

ومَا احتنْجَـابي

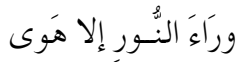

بِه التَتَاهِي تَدَنَّى

$$
\text { صَوبَ مَحُحَياه }
$$

ومَا انْشطَاري سوى شَوَقِ

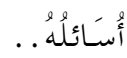

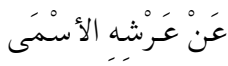

أو عَنْ سِّرِ مَعْنَاهِ 25.

مما يحول الهوى إلى نقطة لالتقاء ثلاثة أقانيم هي النص / الذات / المرأة. لنا أن نطلق عليه مجمع الأهواء. 


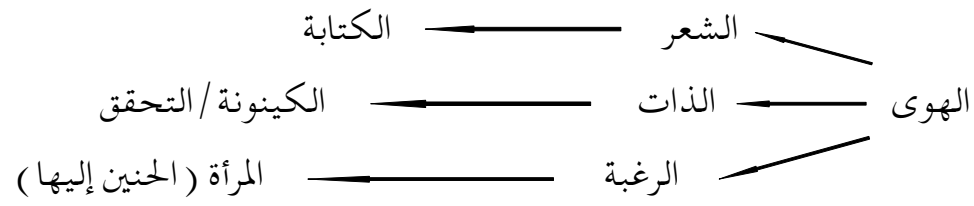

2 ـ ظل الهوى / العناوين الداخلية 2 ـ 1 عنوان للتجاوز / كتاب الجفر :

يستمر الإِيقاع العنواني على نفس الوتر الاستهوائي، إذ يفتتح الديوان

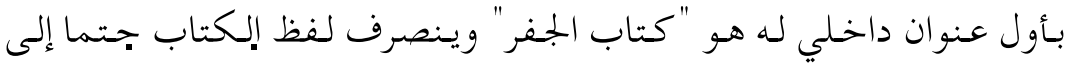

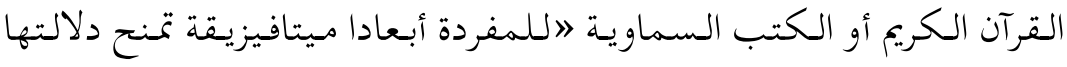
الاصطلاحية وضعية الهـدى ( مطلق الإِبانة ) ، وحين توضع الكلمة عـنوانـا على عمل ما فلاشيء يمنع عمل مطلق تلك الدلالات على محور العنوانها

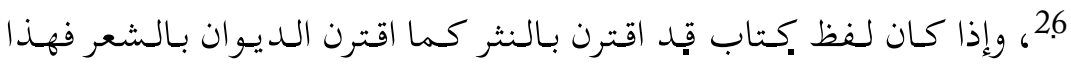

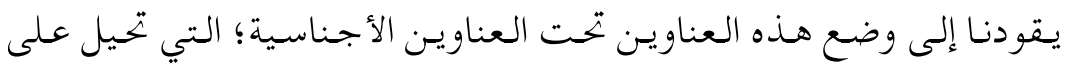
شكل النص وتعود في أصل توظيفها واستغلالها إلى الكتابة الصوفية. يعيدنا عنوان كتاب الجفر بحركة ارتدادية في الزمن ولو بنسية ونسبة بسيطة

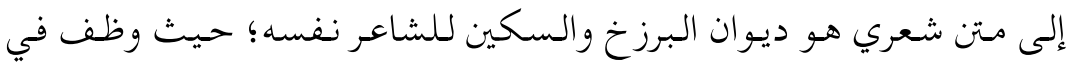

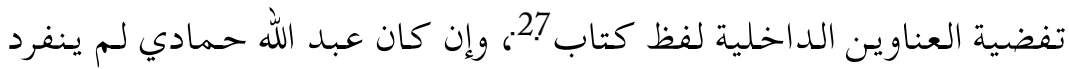
باستغلال اللفظ في بناء عناوينه الشعرية؛ حيث إنه حاضر بقوة عند أدونيس

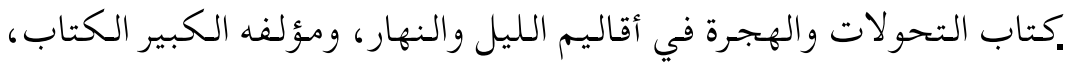
أمس المكان الآن ) 28، وبحركة أقوى وأشد وقعا يستحضر في الذاكرة عنوانا

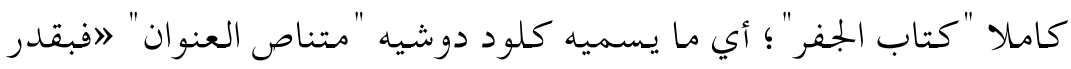


ما يرتبط العنوان بالنص اللاحق له، يتعالق كذلك مع عناوين من الحقبة

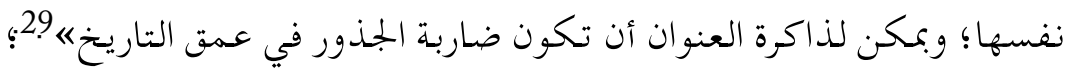

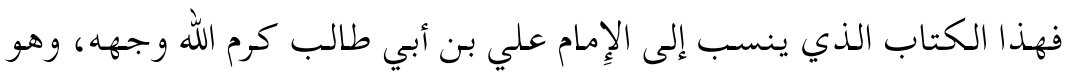

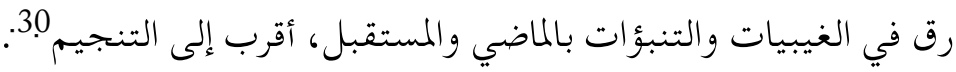

$$
\begin{aligned}
& \text { عُمرِ يَتَوسَدُ الصَّخْرَ والمَرايَا }
\end{aligned}
$$

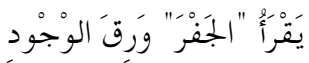

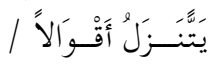

$$
\begin{aligned}
& \text { خَطَـَايَا } \\
& \text { كتَابَا مُنَجَمًَا مَجْهُو لا ل... }
\end{aligned}
$$

العنوان بهذا الصورة يتناص مع عنوان كتاب خلافي مجهول، ذلك أننا لا نسلم أن عليا بن أبي طالب قد كتب كتاب الجفر، إلا أن العنوان الشعري

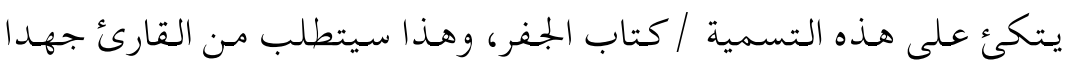
قرائيا تأويليا، كما أن كلمة "الجفر" ذاتها تثير في القارئ الرغبة في معرفة كنهها اللغوي والدروب اللغوية لكلمة الجفر أربعة:

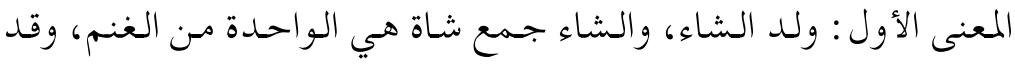
استعمل لفظ الجفر في لغة العرب بهذا المعنى مع تحديد دائرة شموله لأفراد الغنم ليختص ببعض أولاد الشاء دون البعض الآخر، فخصوه تارة بولد الشاء الذي عظم واستكرش واتسع جنباه 32. المعنى الثاني : للفظ الجفر هو : البئر الواسعة التي لم تبن بالحجارة 33.

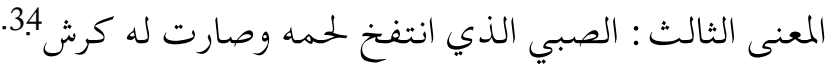
المعنى الرابع: هو الجمل الصغير :35. 
ومن اللافت وجود روايات لدى الشيعة عن الأئمة لم تفسر الجفر بالمعاني اللغويـة بل فسرته بالجلد ونسبته إلى الشاة تارة، وإلى الثور تارة أخرى وإلى عـكاظ ثـالـثة، كـما أن الجـفر أربـعة، كـتاب الجـفر، والجـفر الأحسـمر والجــفر الأبيض، الجفر الرابع جلد الثور36، ولقد أنكر' ابن تيمية أن ينسبب الكتاب إلى' علي بن أبي طالب واعتبره من الأكاذيـب، ومع كل ما يـلف الكتاب من روايـات وخلاففات واختـلافات، تـنتخبه الذات الشاعرة عنوانـا لنصها، هـذا

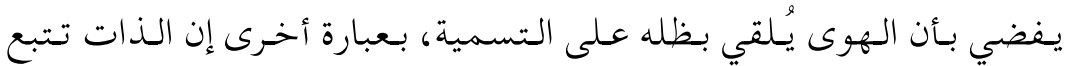
مـنطقها وهـواهـا في الخـرق والتجاوز بـتسمية تفتتح الباب للتساؤلات؛ هي محاولة لزعزعة أفق الانتظار فالشعر لخطاب انشقاقي ينشد تحرير الكائن من سـلطة الممنوعات والمحرمات والمتعاليات، إنه مفتوح علمى الرغبات والأهواء والنزواته 37. يقول: ت

$$
\begin{aligned}
& \text { مُفْعَمِ بَالْهَوَى والمَتَارِيس }
\end{aligned}
$$

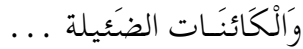

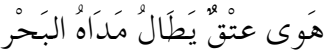

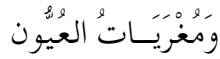

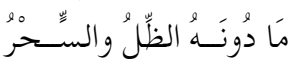

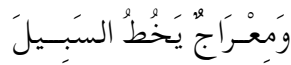

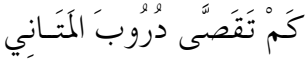

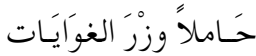

$$
\begin{aligned}
& \text { وعطرَ سُكْر الجُفُون ـ... } 38 .
\end{aligned}
$$

تُؤسِِّ الذاتُ بهذه العنونة لفعل الانتهاك "ينشر كفه للخطايا" وتدخلنا 


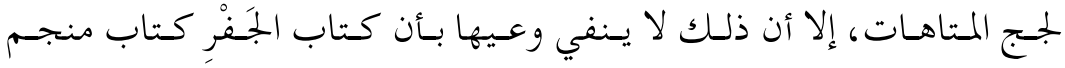
مجهول / كتاب قيل إنه عبارة لاعن لوح القضاء والقدر علم المنايا والبلايا

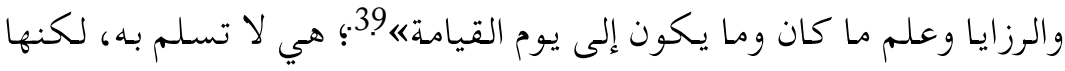
تسلم بأن الإبـداع لا يحهد بخط، هـذا ما أفضت بـه عتبتها التصديرية تنبيه

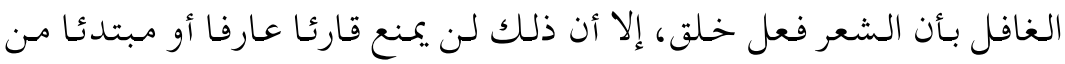

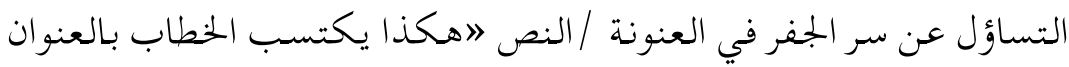
فاعليته، ليمارس ضغوطه على المتلقي، وينخرط في العالم، بـه ومن خلاله

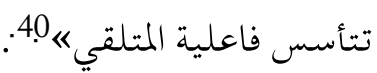
ما نتلمسه هو أن حركية النطق بالهوى لاتتنامى من لمما ظل مصادرا

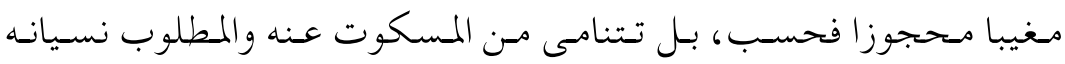

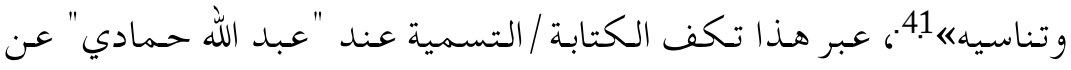

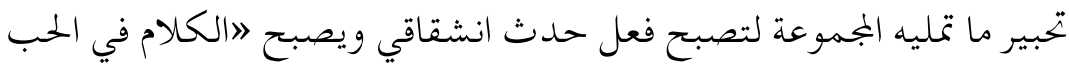

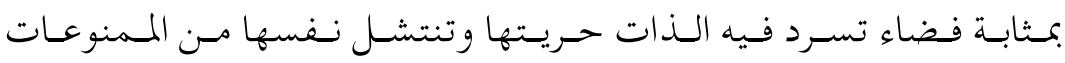

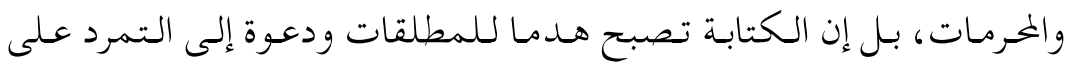

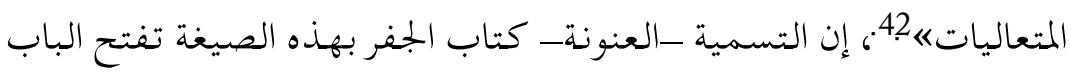

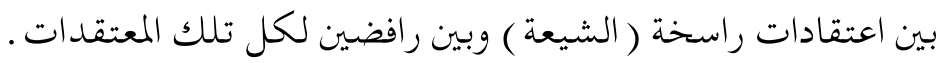

$$
\begin{aligned}
& \text { | يَسْتَدَرِجِجُ اللَّحْظَةَ }
\end{aligned}
$$

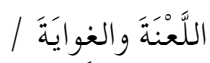

$$
\begin{aligned}
& \text { والنُذُورَ } \\
& \text { يَكَبْرُ فِي تَوسُلهِ المَدَى } \\
& \text { يَستتفيقُ الفُتُورُ .... }
\end{aligned}
$$


يتشغل العنوان -كتاب الجفر- على وظيفة الاغراء بامتياز ؛ فهو يستفز القارئ بالفعل والقوة للبحث عن حكاية الجفر خارج النص وداخله . تحمل هذه الوظيفة قوة إنجازية تجعل الشاعر يعمل على تحميل العنوان بعدا إغرائيا قادرا على جـذب القارئ إلى النص، فالعنوان هو أحسن سمسسار للكتاب على حد قول جيرار جينت

\section{2ـ 2 عنو ان مارق / طقوس خرمية :}

تعمل العنونة في الديوان "أنطق عن الهوى" على خرق الأفق لتستوقف

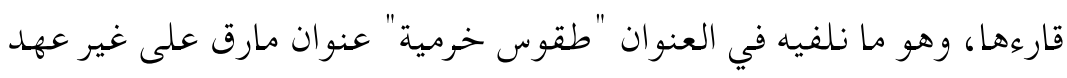
العنونة، مروق بابك الخرمي، فرقة سرية لاعملت في فـارس قبل الاسـلام

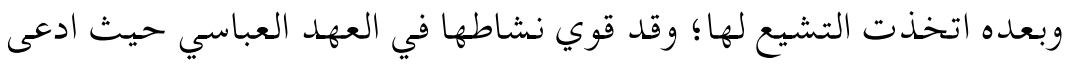

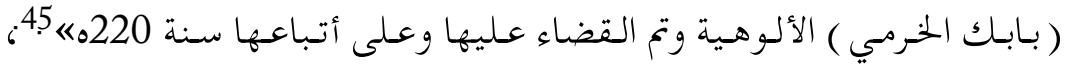

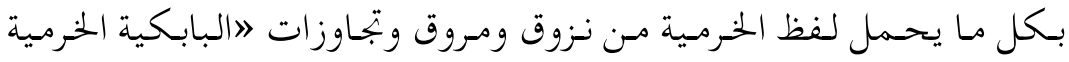
كانوا يذهبون مذهب الخرمية والمزدكية من إباحة اللذات والشهوات والمواساة

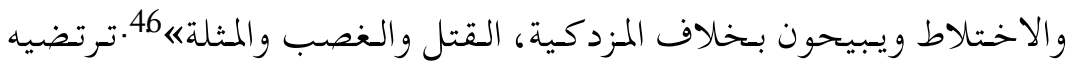
الـذات عـنوانـا لـنصها؛ ويستـحضر مـرة أخـرى المرفوض في صـوغ الـعنونـة

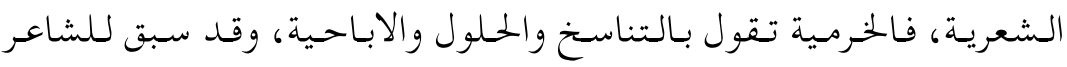

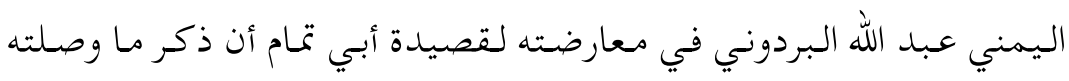

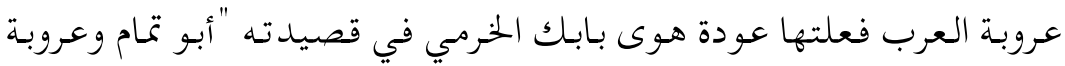

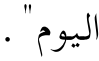

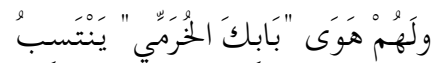

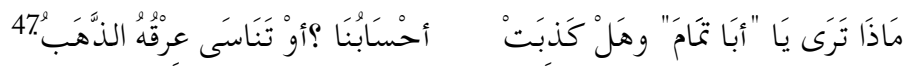


والنص الحمادي المشحون بشعريـة صوفية، يرمي إلى ذات المسار الرافض لما آل إليه الوضع العربي، هو حاضر يعيد رسم ملامح زمن الفتن .

$$
\begin{aligned}
& \text { هِي الحَرَبْ مُشَرَعَةُ النصَّالِ } \\
& \text { تَقَمَحَتَتَ شَجَرَ الفُرات }
\end{aligned}
$$

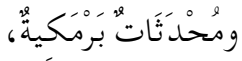

$$
\begin{aligned}
& \text { حَمَكَت لظَى جمَ الغضَّا } \\
& \text { دَنس الجَليل }
\end{aligned}
$$

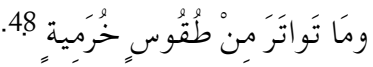

فالطقوس الخرمية، ممارسات تجعلنا نقف مابين العصرين، العصر العباسي وما وقع فيه من فتن وزندقة؛ فالدولة العباسية سادت العالم بسياسة ممزوجة بالدين والملكك، أخيار الناس وصلاحهم يطيعونها تـدينا والباقون يطيعونها رهبة أو رغبة ثم مكثت في الخلافة والملكك في حدود ستمائة سنة، وليس ببعيد عنها عصرنا هذا وما يسوده من فتن وخطايا ـ هي الأنا تحاول أن تعبر

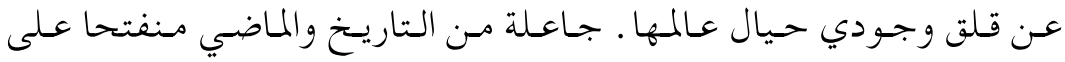
الحاضر بهزائمه .

$$
\begin{aligned}
& \text { إيه بَرَرامكَةُ الزَّمَان تَقَدََّّهوا }
\end{aligned}
$$

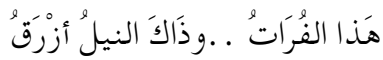

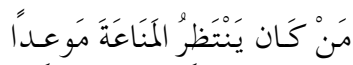

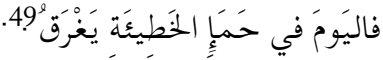

تـوضـح هـذه العناويسن ومـا سـيأتي الحـد يـث عـنه، مـدى هـوس السشاعر بالعنونـة ليس في ذاتها وحسبب وإنما اتخاذها استراتيجية في التسمية حين 
يغلدو نصا بـكامله تمارس عبره الكتابة لافتضاض المألوف ، السائدد، المغلق،

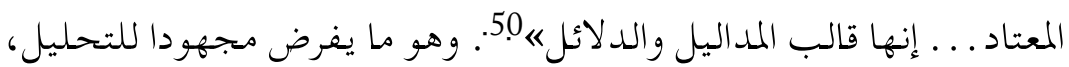
نـعتقد أنـنا بـحاجـة إلى طـاقـة قرائسية مخصوصـة لـففير الطاقة الكامـنة في العنونة.

\section{2 ـ 3 عنو ان للحجب / ستر الستور:}

الستر عند الصوفية \الستر والتجلي، العوام في غطاء الستر والخواص في

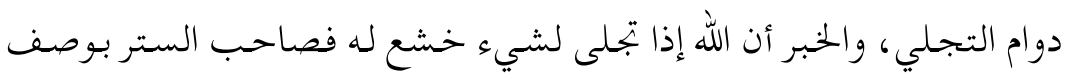
شهوده وصاحب التجلي أبـا بنعت خشوعه و الستر للعوام عقوبة وللخواص رحمة إذ لولا أنه يستر عليهم ما يـكاشفهم بـه لتلاشو اعند سلطان الحقيقة

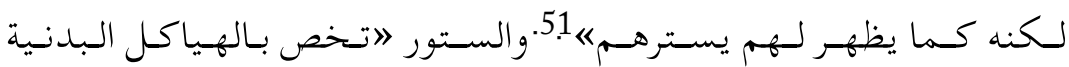

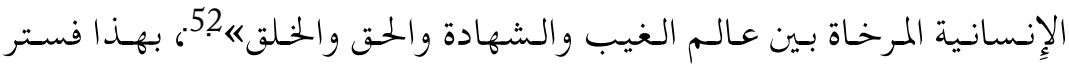
الستور عنوان غارق في البعد الصوفي بامتياز .

$$
\begin{aligned}
& \text { هَوى بَنْفسكَ }
\end{aligned}
$$

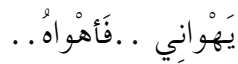

$$
\begin{aligned}
& \text { وطَيْفُ عَرْشِكَ يَلْقَاني }
\end{aligned}
$$

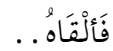

$$
\begin{aligned}
& \text { ومَا احْتْجَابِي }
\end{aligned}
$$

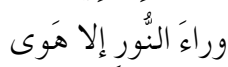

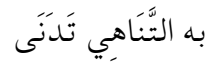

$$
\begin{aligned}
& \text { صَوبْ مَحَيَاه } \\
& \text { وما انْشُطَاري سوى شَوْقِّ } \\
& \text { أُسَأَيُلُْه }
\end{aligned}
$$




\section{عَنْ عَرْشَه الأسمْنَى

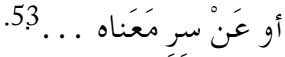

تمتد دلالة العنوان الرئيس ( أنطق عن الهوى) ) إلى نص بستر الستور، ليحق

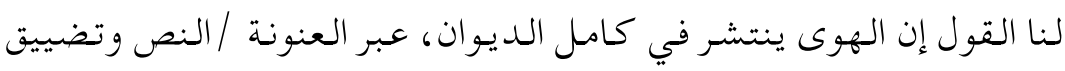

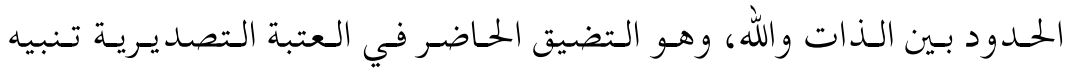
الغافل لغوستاف فلوبير Gustave Flaubert (1821-1880) صاحب المقتبسة (L'auteur dans son ouvre doit être comme dieu) (dans l'univers présent partout et visible nulle part الكاتب في عمله أن يكون مثل الله في الكون حاضر في كل مكان ولا يظهر

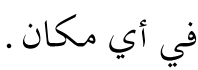
من خلال التشـديد على أن الشعر والكتابة فعل خلق ، تسعى الممارسة النصية عبر فعل النطق بـالهوى إلى الإعلان عن الرغبة في تقعديم الـذات

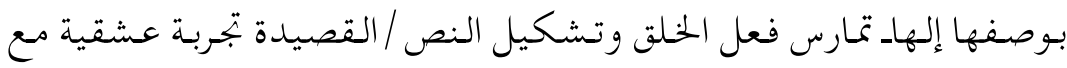
أنساق اللغة والحرف هو المعشوق. هي الكتابة في أسمى تصوراتها الإِيحائية المتجاوزة، فسر اللغة الشعرية

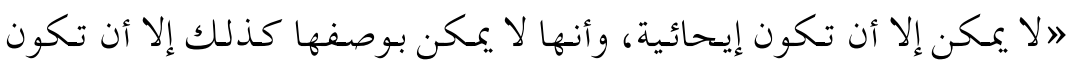
غامضة، فهي الأخرى صورة عن هذه العلاقة بين المرئي واللامرئي، وليست

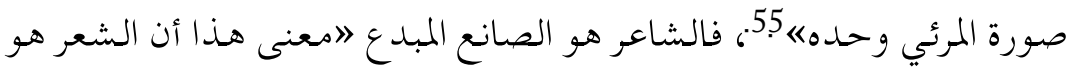

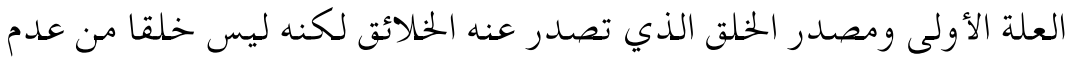


بل هو الخلق هـن عدم العدم بتعبير ابن عربي، على اعتبار أن سلب الوجود هو العدم، وإذن فسلب السلب أو عدم العدم هو الكينونةهابك. من اللافت أن قصيدة (ستر الستور ) تقوم على تواتر كبير لحرف الهاء، وهو حرف هوائي، يأتي من جوانبة وأعماق النفس، يتكرر الحرف ( 57 مرة )

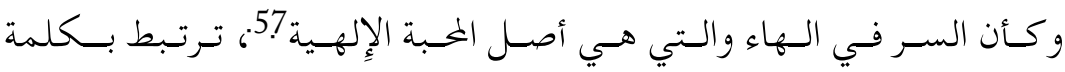
( الهوى )، وما جاورها من عالامات تشتغل ضمن السياق الصوفي فتحضر ضمن ( يهواني، أهواه، ألقاه، محياه، أسائله، عرشه، هو، التماهي، تجرده، دنياه، مدامعه، نجواه، أفناه، ساحله، مولاه، مورده، يمـناه، يسراه، صولته، سـلواه، مسـراه ف فحواه، خـواطـره، مجـراه، أخـراه، مـرسـاه، مـغزاه، مـعناه، بقاياه )، تتجلى رمزية الهاء في : هاء لفظ الجلال ( الله ) وهاء (هو ) التي ترمز إلى الذات الصوفية الواصلة، والتي تـنعدم إنيتها في إينية المحبوب، فتصير الهاء معبرة عن ذاتين في آن واحلد، ويـحصل هذا الاشتراك الدلالي في حال الاتحاد، أي حينما تنتفي الصفات البشريـة، فالذات الإِهية هي نور يغشى الكائنات كلها كما يخترقها، لتصير تلك الموجودات عينه، ومظهره، وتجليه

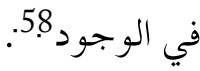

$$
\begin{aligned}
& \text { هُو التَمَاهي تَمَادَى } \\
& \text { في تجرَدِد } \\
& \text { وأَتْقَلَ القَلْبَ َِرَ } \\
& \text { من أوضْصَار دُنهِاهِ } \\
& \text { سَالَ فَي السيَّل }
\end{aligned}
$$

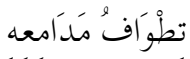

$$
\begin{aligned}
& \text { وعَاين الحَيْفَ لَعَ }
\end{aligned}
$$




\section{منْ سُنْطَان نجْوَاه \\ تَفَجَرَ المَاردُ الناّري

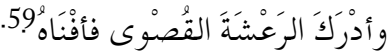

ينفتح العنوان /النص بستر الستور بعلى صوفية متعالية، تستمد دلالتها

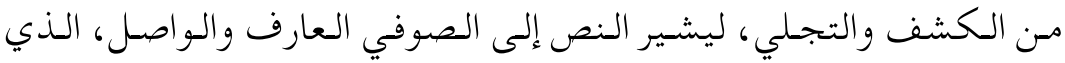

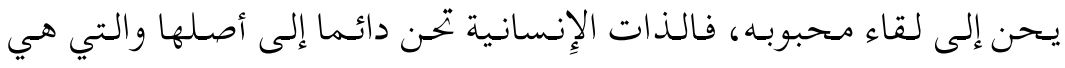

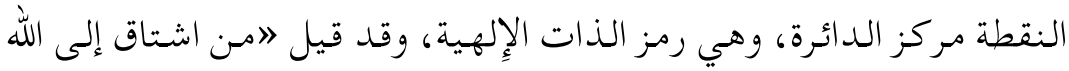

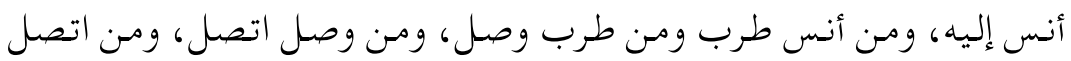
طوبى له وحسن مآبه 60. يقول :

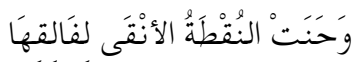

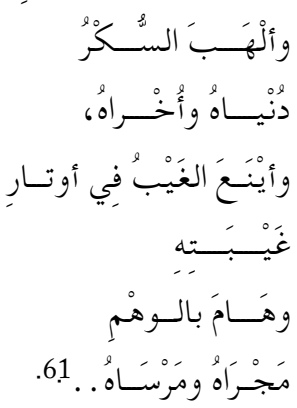

2 ـ 4 عنو ان للخلق / كاف الكون :

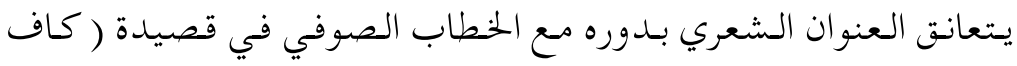

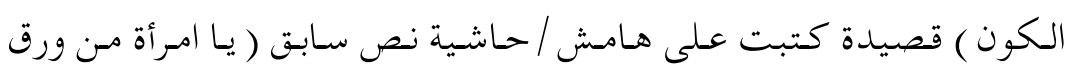

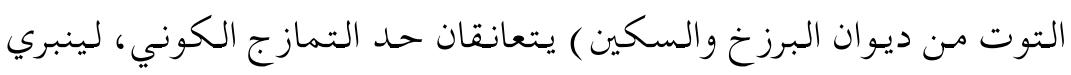


الـنفس الـشعري في استحضار الأنثنوي يـعزف العنوان / الـنص عـلى هـبات

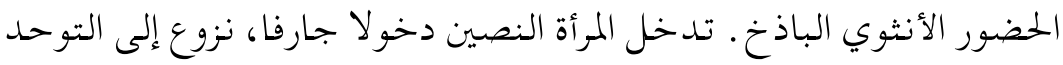

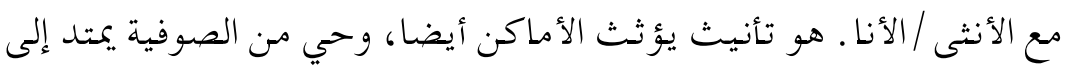

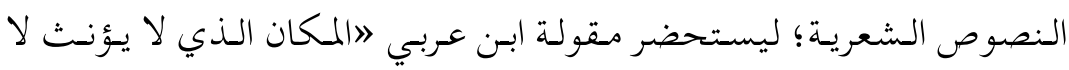

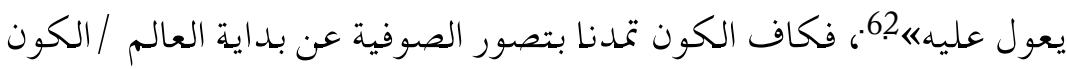
"فإذا الرجل مدرج بين ذات ظهر عنها وبين امرأة ظهرت عنه، فهوس مؤنثين تأنيث ذات حقيقي، كآدم مذكر بين الذات الموجود عنها ومن حواء الموجودة

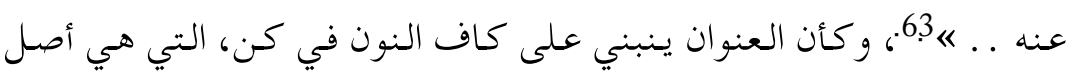
البدء( الكون )، والتكوين هو المعنى الذي يعطيه ( ابن عربي ) للفعل الإِلهي

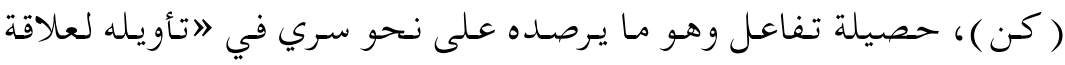
الكاف بالنون في الكن مع التنصيص على دلالة اختفاء الواو بينهما وانطلاقا

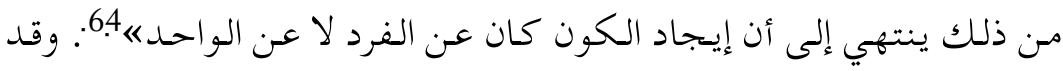

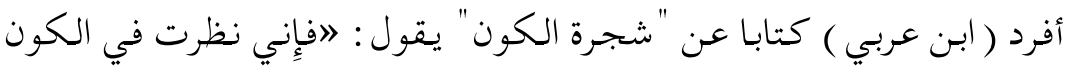

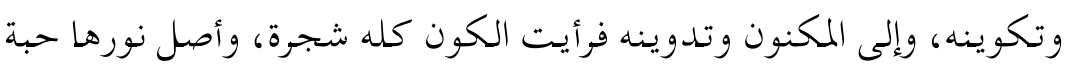

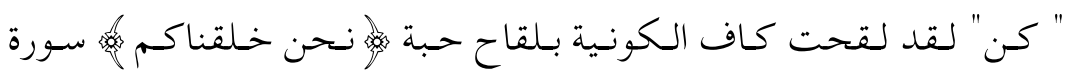

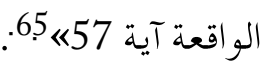

تسـتند الـذات الشناعرة إلى هـذه الخـلفية المعرفية (لابسن عربي ) لـتبدأ حريتها مـن العنونة عبر فعالية اإيحائية حضور مستقل يصدر عن رؤيـا للوجود وللعالم وللحياة كتكوينات دائمة التحرك والتحول، وبذلك يخت يخرج

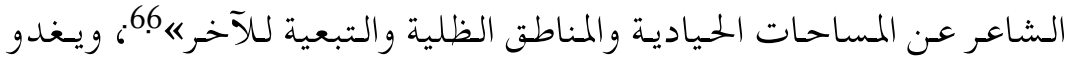
العنوان / النص (كاف الكون ) مجلا للأنثوي الخالق لافـالمرأة هي المرآة ، 
والمظهر الذي يتأمل فيه الرجل صورته، التي كانت تشكل وجوده الخفي،

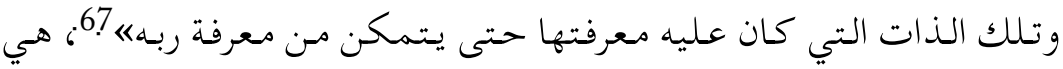
الدلالة القوية ذاتها الحاضرة في نص ( يا امرأة من ورق التوت )،

$$
\begin{aligned}
& \text { سَيَـنَتي . .سادنَةُ العُشـاق } \\
& \text { والأوتَسـار: }
\end{aligned}
$$

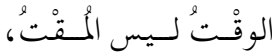

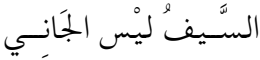

$$
\begin{aligned}
& \text { من قُبة السََّّْمَاء. }
\end{aligned}
$$

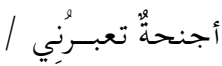

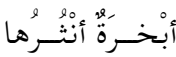

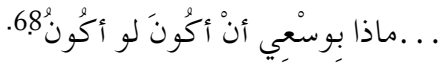

هو الحنين إلى لأنثوي المتفجر داخل النص / الذات ( سادنة العشاق ، سر البداية والأصل؛ فحنين 》الرجل إلى المرأة حنين الشيء إلى نفسه فِإن حواء خلقت واشتقت مـن آدم، وحـنين المرأة إلى الرجل حـنين الشيء إلى وطنه، فالمرأة خلقت عن الرجل ليحن إليها حنين من ظهرت سيادته بها وهي تحن لهن

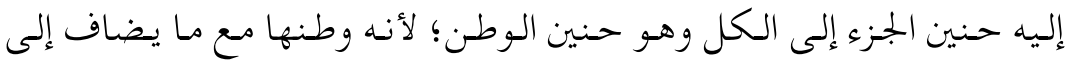

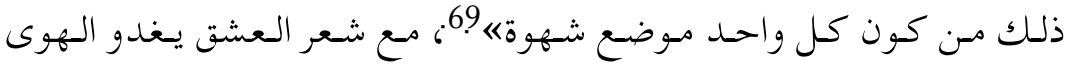
نضالا ضد المؤسساتية القمعية التاريخية وفعل خرق للثقافي السائد، فالأنا

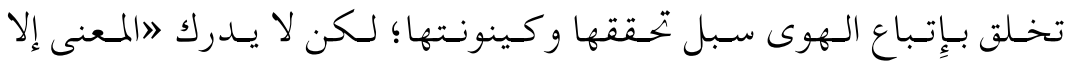
بالتماهي والمجاهدة والمكاشفة والمحو والتقلب، فهو لا يأتيك وإنما ترحل إليهه 


$$
\begin{aligned}
& \text { حَبِيبَتِي . .لا تسْألينِي عن جَذْوِة للنَّارِ }
\end{aligned}
$$

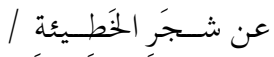

$$
\begin{aligned}
& \text { عنْ مـوعد البـدايات }
\end{aligned}
$$

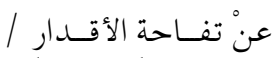

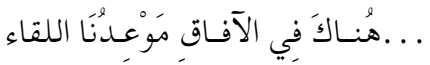

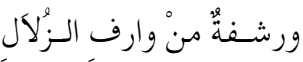

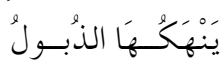

$$
\begin{aligned}
& \text { وطَائرُ من شتاعِ.... }
\end{aligned}
$$

ومسن هـنا تنشأ عـلاقة بين المتلقي / العنوان / الـنص، فهـذه العنوانات تحمل من ( الفتنة ) و( سحر العنوان ) ما يؤهلها للرقي في لامعارج الشعرية

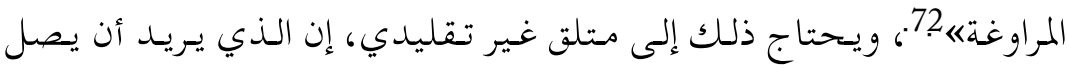
إلى الحقيقة الشعرية في النص عليه تجاوز ظاهر اللغة . يوظف الشاعر رمزية الهاء في المقطع الأخير من نص كاف الكون ؛؛ حيث الروي هو الهاء، تدور حول مركز واحد هو ( الهوى) )، هوى المرأة / الحرف، الكتابة :

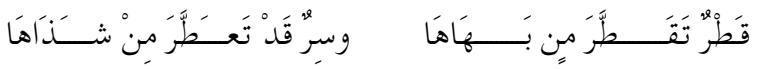

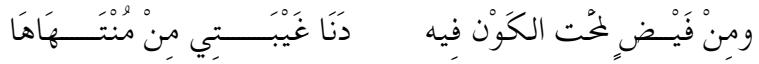

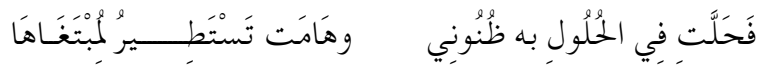

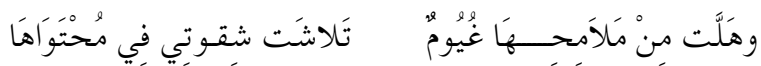

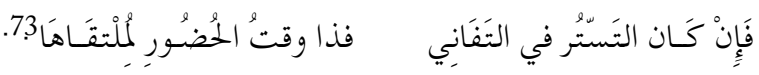

\section{5 مائية الثعر / جوهرة الماء:}

تتلبس الذات القائة بعبق الفيض المنسل من نص جوهرة الماء، و"جواهر 
القلب سبعة والقلب سبع خزائن كل خزانة محل لجوهرة"74 جوهرة الذكر، جوهـرة الشوق، جوهرة المحبة، جوهرة السر، جوهرة الروح، جوهرة المعرفة، جوهرة الفكر، وتضيف إليها الذات جوهرة الماء

$$
\begin{aligned}
& \text { ( . (. ) أنْتَ والسَّبَع } \\
& \text { مَدَارَاتَ }
\end{aligned}
$$

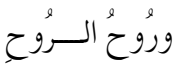

$$
\begin{aligned}
& \text { وما دُون المَلْفُوظجِ } 75 .
\end{aligned}
$$

كما للماء قوته ودلالته فكل ما يرغبه القلب بالإِمكان تحويله إلى ماء، كما أن الماء يوحي بـشعريـة التحول والانتقال، حـرقة الشعر وقلق الوجـود، يؤكده بحثث الشاعر المستمر عن بـديل يعيد تأثيث البياض، بما يحمله الماء من دلالة على النماء والخصب والأنثوي وأصل البدء، هي دلالة تحيل أيضا على ماء الشعر؛ فالكتابة حين "تذوب في ماء الخلقل، . .. تتغير العلاقات بين الكلمات والأشياء، ويدخل العالم في كون من الصور الجديدة" 76. العنوان / النص جوهرة الماء حالة للتحول، تجربة تحول عن الواقع، هو فعل ولوج الذات إلى عالم التجربة، الرؤيـا الصوفية / الاشراقية؛ وهي رؤيا تقوم على الوجدل والعشق، تنصهر عبرها الذاكرة في النسيان وتدخل في استغراق

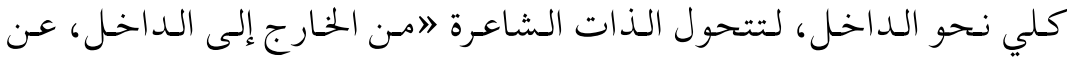
الخـارج بوصفه عالم الرؤيـة والوضوح والتحـد يـد ، إلى الد اخل بوصفه عالم الرؤيا والغموض واللاتحد يده"77.

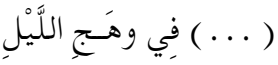

$$
\begin{aligned}
& \text { المُورق بالعـــــَّة }
\end{aligned}
$$




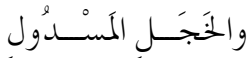

$$
\begin{aligned}
& \text { عَلـــى قَافــلة النُّـور }
\end{aligned}
$$

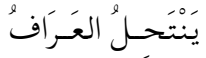

$$
\begin{aligned}
& \text { حَكَايا سُور الإستـرَاء }
\end{aligned}
$$

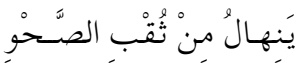

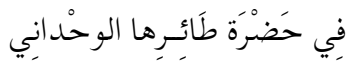

$$
\begin{aligned}
& \text { المَعْرُوروف بالسلالَوْنْ }
\end{aligned}
$$

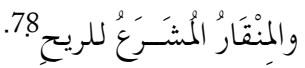

هـذا الارتـقاء، يسـتحضر شـفافية لا تـنفي وجـود غـموض يـلف الـنص، فالوصـول إلى جـوهـر الشيء يـعني الانفصسال عن الظاهـ والاتصسال بـالباطن.

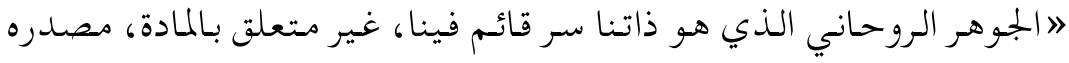

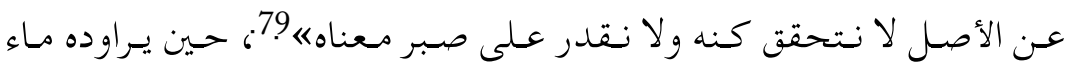
الـكتابـة مـابـين السـماء والأرض، تـتشكل عـنـاصـر الـثلاثـة ( المـاء، الـهواء، التراب ) يتحول جوهو الماء إلى ذنب يؤرقهه وعتقه في لظى الجمر والنار، كل هـأفي نص يـقدم اللدعوة إلى القراءة والتأويل ويتحول الماء في العنوان إلى

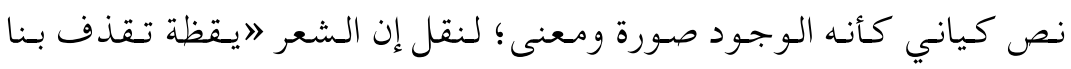
خارج فواش المرئي «80.، تتحول الكتابـة إلى تمجيد للماء وصوع مقدمات ماء حيوية بـا يستمر الشعر.

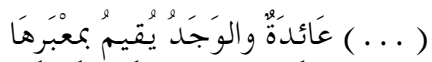

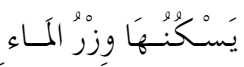

$$
\begin{aligned}
& \text { وعتَـــقُ النَّـار }
\end{aligned}
$$

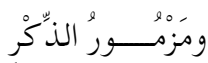




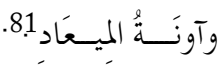

كما تتحول الكتابة إلى وسم بالنار يطاول الذات في العنوان (نار الجنة )؛ فالنار ترمز للقهر والمحبة معا لا أما أنها رمز القهر فلأنها تفني كل ما اتصل بها وتحوله إلى طبيعتها، و كذذلك الحق يفنى فيه كل ما اتصل بـه، أي كل مـن تحقق من وححدته الذاتية أما أنها رمز المحبة فلأنها مصدر النور الحبوب لذاتهه.

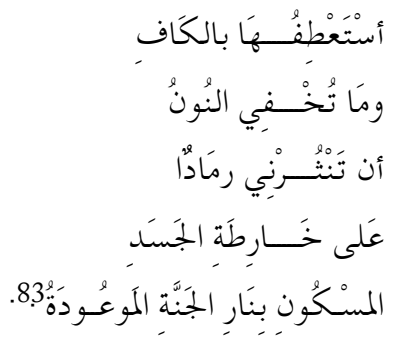

هـذه الغوايـة المنتشـرة في الديـوان يـفرد لها الشاعر عنوانـا / نصا بكامله ليرسـخ قـدم العاشق عـمقا داخل الـديـوان، ويـبدأ الهوى بـتأرجـح بـين المرأة / القصيدة بـدءا من العناوين / النصوص الغوايـة، سيدة الريح، نوبـة زيدان، في البدء كان الحـب، المحبة الحمقاء شعرها الليلكي، النوارس تسكن المقابر، وإن كنا نميز عناوين تشـتغل على ( الوظيفة الإيـحائية ) وهي الغواية / سيدة الريح /نوبـة زيدان /نار الجنة وهذه الوظيفة على صلة بـ( الوظيفة الوصفية ) التي نجـدهـا في بـقية العناويسن المـذكورة، وتـنطلق هـذه الوظيفة مـن فرضسية الحضور الإيحائي ذي الدرجات المتفاوتة، هناك قيمة إيحائية في العناوين مع وجـود ( وظـيفة إغـرائـية ) نظظرا لارتـباطهمها بـبعض، ومـا نشـير إلـيه أن هـذه النصوص تتسمى ببعض التقريـريـة إن لم نقل تـكاد تنتفي الشعريـة في كثير 
منها، بل ينحصر مدُّ الشعرية في العنونة ولا يفارقها إلى ما سواها .

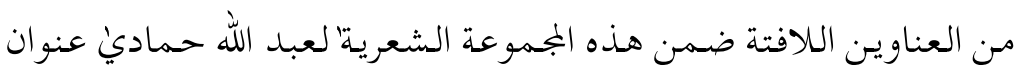

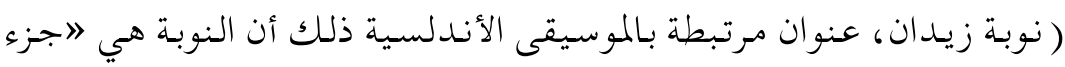
أو مقطع من الصوت الذي يرادف معناه الأغنية الموسيقية حسب الاستعمال المشرقي ... تطور المفهوم إلى إنتاج موسيقي كامل، له مقوماته اللحنية والإِيقاعيةه8.

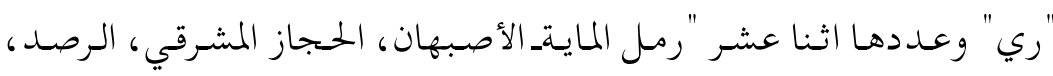

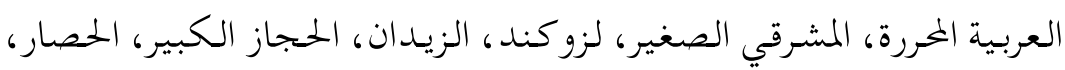

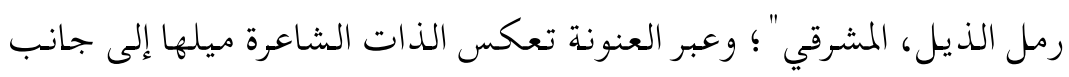
موسيقي مخصوص يقرن المرأة بالطرب والفتنة، دون أن يصل بنا إلى افتتان

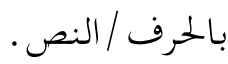

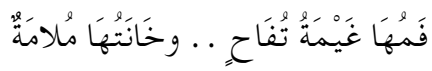

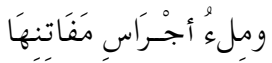

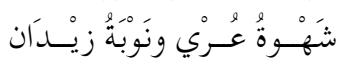

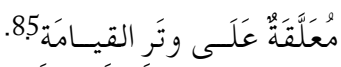

هذه الميولات التي تفيض بها الذات تجاه نوع موسيقي مخصوص تتجلى

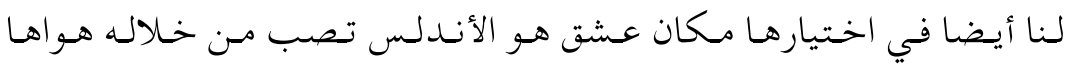

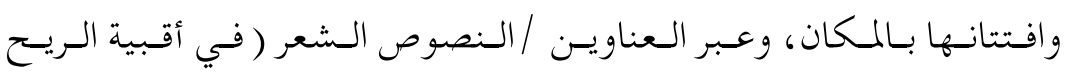
والزعفران، أنـدلس الأشواق ) تتمظهر الوظيفة الموضوعاتية Thématique

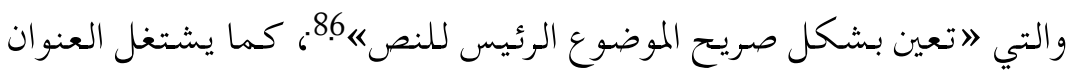

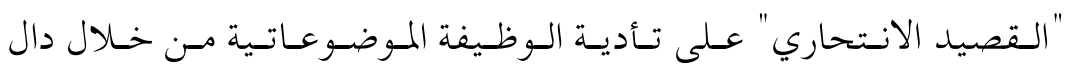


(الانتحاري ) وتحديد خطابي Rhématique يحمل وصفا تجنيسيا عبر دال

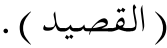

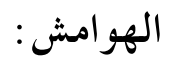

1 شعيب حليفي: هوية العلامات في العتبات وبناء التأويل، دار الثقافة، المغرب،

2005، ط 1، ص ص 19.

2 رشيد يحياوي: الشعر العربي الحديث، دراسة في المنجز النصي، إفريقيا الشرق،

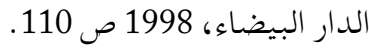

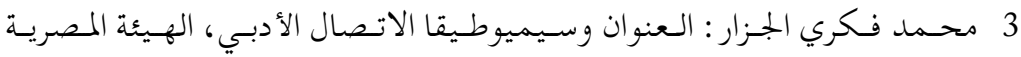
للكتاب، مصر، 1998، ص 23.

4 خالد حسين حسين: "سيمياء العنوان، القوة والدلالة ( النمور في اليوم العاشر لزكريا ثامر نموذجا )"، مجلة جامعة دمشق، مجلد 21، العدد 3 - 4 ، 2005 ، سوريا، .351

Grivel, Charles, Production de l'intérêt romanesque, La Haye-Paris,. 5 Mouton, 1973, p. 166 6 عبد الله حمادي : أنطق عن الهوى، كـ 1، دار الألمعية، الجزائر، 2013.

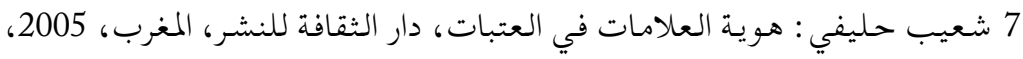

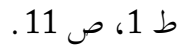

8 على آيت أوشان : السياق والنص الشعري من البنية إلى القراءة، دار الثقافة، الدار

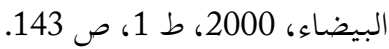

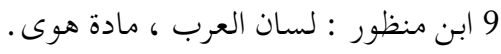


10 المنجد في اللغة والأعلام، دار المشرق، بيروت، 2014 ط 40، ص 879. 11 محمد الداهي: سيميائية السرد بـحث في الوجود السيميائي المتجانس، رؤية

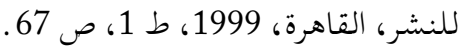

12 أبو الفرج عبد الرحمـن بـن الجموزي : ذم الهوى، تحقيق خـالد عبد المطلب، دار الكتاب العربي، 1998، ط 1، ص 8.

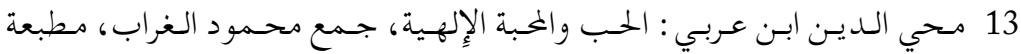
الكاتب المغربي، دمشق، 1982، صن لـ 79. 14 زكي مبارك : مدامع العشاق، دار الجيل، بيروت، 1993، ط 1 1، ص ص م 10. 15 رجاء بـن سلامـة : العشق والكتابـة قراءة في الموروث، مـنشورات الجملم، ألمانيا، 2003، ط 1، ص ص 9 16 هـنري كـوربـان : الخـيال الخـلاق في تصوف ابـن عـبـي، تـرجمة فريــ الزاهي، منشورات مرسم، الرباط، 2006، ط 1، ص ص 140. 17 على آيت أوشان : السياق والنص الشعري من البنية إلى القراءة، ص 143. 18 ابن عربي : فصوص الحكمم، تعليق أو العلاء عفيفي، دار الكتاب العربي، 1980،

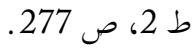

19 عببد الله حسمادي : أنطق عـن الهوى، دار الألمعية، قسنطينة، 2011 ، ط 1 ، ص 135. ينظر محمد لطفي اليوسفي : بيانات، سراس للنشر، تونس، 1993، طبعة جيب.

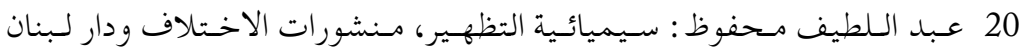

$$
\begin{aligned}
& \text { ناشرون، بيروت / الجزائر، 2009، ط 1، ص } 151 .
\end{aligned}
$$

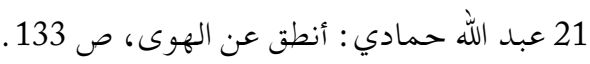

$$
\begin{aligned}
& 22 \text { المصدر نفسه : ص } 136 .
\end{aligned}
$$

23 محسمد الداهي : سيميائية السرد بـحث في الوجـود السيميائي المتجانس، ص 
24 هـنري كـوربـان : الخـيال الخـلاق في تصوف ابـن عربي، ترجمة فريـد الزاهي،

$$
\begin{aligned}
& \text { منشورات مريم، الرباط، 2003، ط 1، ص } 148 . \\
& 25 \text { عبد الله حمادي : أنطق عن الهوى، ص } 55 .
\end{aligned}
$$

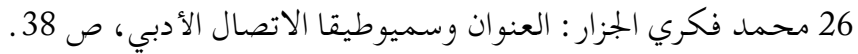

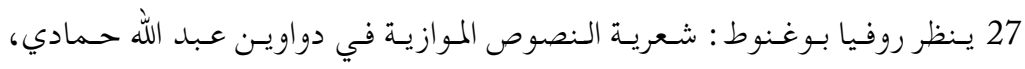
مخطوط ماجستير، جامعة منتوري قسنطينة، 2006-2007. عملنا على تفضية عناوين

$$
\text { ديوان ( البرزخ والسكين ) . }
$$

28 أدونسيس : الـكتاب أمسس المكان الآن، مخططوطـة تنسـب إلى المتنبي يـحققها

$$
\text { و ينشرها أدونيس، دار الساقي، بيروت، 1995، ط 1، ( ثلاثة أجزاء ). }
$$

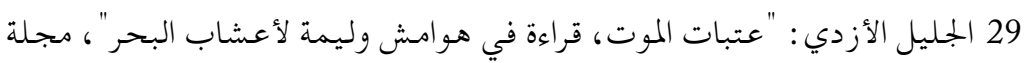

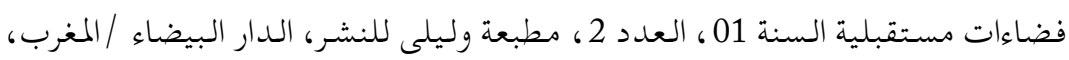
. 1996، ص ص 41

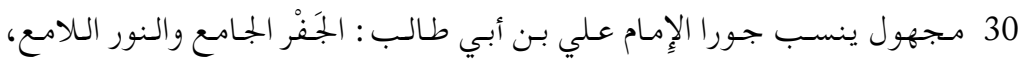

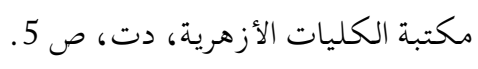

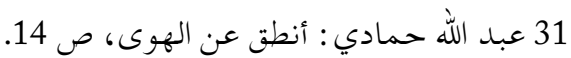

32 أحسمد بـن محسمد بـن عـلي المقري الفيومي : المصبباح المـنير في غـريسب الشـرح

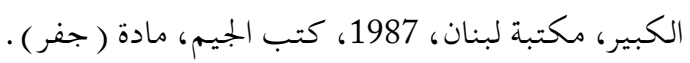

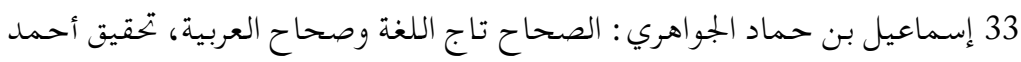

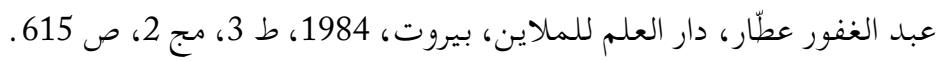
34 ابن منظور : لسان العرب مادة ( جفر ) .

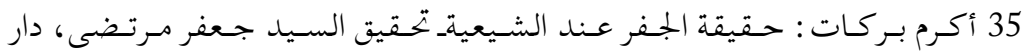

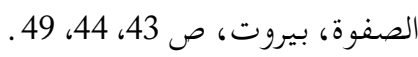
36 المرجع نفسه : ص 49. 
37 محممد لطفي اليوسفي : فتنة المتخيل الكتابة ونداء الأقاصي، المؤسسة العربية

$$
\begin{aligned}
& \text { للدراسات والنشر، بيروت، 2002، ط 1، ج 1، ص } 14 . \\
& 38 \text { عبد الله حمادي : أنطق عن الهوى، ص } 16 . \\
& 39 \text { أكرم بركات : حقيقة الجفر عند الشيعة، ص } 61 .
\end{aligned}
$$

40 خـالد حسـين حسـين : في نظريـة العنوان، دار التكويـن، دمششق، 2007 ، ط 1، ص 171.

41 محمد لطفي اليوسفي : فتنة المتخيل، خطاب الفتنة ومكائد الاستشراق ، ج2 2 ،

$$
42 \text { المرجع نفسه : ج 2، ص } 43 \text { عبد الله حمادي : أنطق عن الهوى، ص } 113 \text {. } 19 \text {. } 19 .
$$

Génette, G., Seuils, Seuil, coll. «Poétique», Paris, 1987, p. 96.44

45 عبد العزيز سالم : دراسات في تاريخ العرب العصر العباسي الأول، ط 1، مؤسسة

$$
\begin{aligned}
& \text { شباب الجامعة، مصر، 1993، ط 1، ج 1، ص } 155 . \\
& 46 \text { المرجع نفسه : الصفحة نفسها . }
\end{aligned}
$$

47 عبد الله البردوني : الديوان، دار العودة، بيروت لبنان، 1986، ط 1 1، مج 2 2، ص ص

$$
48 \text { عبد الله حمادي: أنطق عن الهوى، ص } 49 \text { المصدر نفسه : ص } 37 \text {. }
$$

50 محمد بنيس : بيان الكتابة، ضمس بيانات، سراس للنشر، تونس، 1995، طبعة

جيب، ص 112.

51 رفيق العجمى : معجم مصطلحات الصوفية، مكتبة لبنان ناشرون، لبنان، 1999،

$$
\begin{aligned}
& \text { ط 1، ص ص } \\
& 52 \text { المرجع نفسه : ص } 53 \\
& 53 \text { عبد الله حمادي : أنطق عن الهوى، صـ صد } 55 .
\end{aligned}
$$


www.larousse.fr/encyclopedie/personnage/Gustave_Flaubert/119630 54 55 أدونيس: الصوفية والسريالية، دار الساقي، بيروت، 1995، ط 2، ص 72. 56 عبد العزيز بومسهولي : الشعر والتأويل قراءة في شعر أدونيس، إفريقيا الشرق،

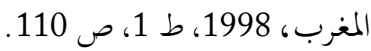

57 أشار الحلاج في كتاب الطواسين إلى أن لكل حرف في لفظ الجلالة (الله ) معنى

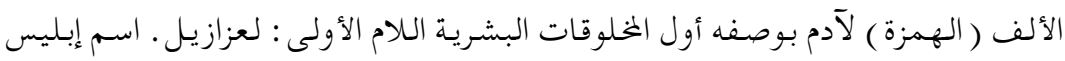
الأول بوصفه موضوع الملامة اللام الثانية : المؤكدة التي تقلب النفي إلى إثبات الهاء:

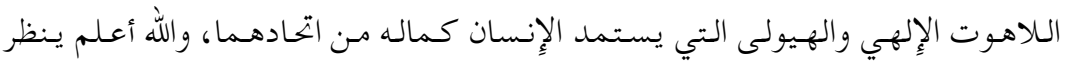

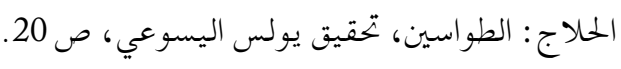

58 محمد كعوان : التأويل وخطاب الرمز قراءة في الخطاب الشعري الصوفي العربي

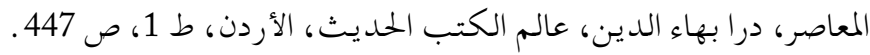

$$
59 \text { عبد الله حمادي : أنطق عن الهوى، ص صله } 56 .
$$

60 عببد المنعم الحـفني : معجـم المصطلحات الصوفية، دار الميسرة، مصر،، 1987،

$$
\text { ط 2، ص } 142 .
$$

$$
61 \text { مبد الله حمادي: أنطق عن الهوى، ص 58-59. } 63 \text { محي الدين بن بن عربي : فصوص الحكم، ص } 187 .
$$

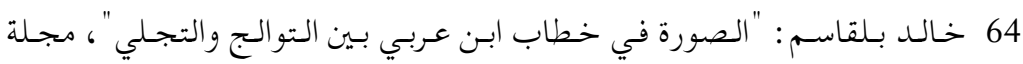

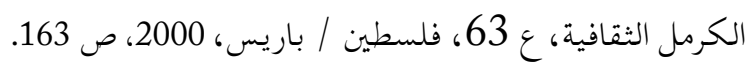

65 محي الدين بن عربي : شجرة الكون، ضبطه وحققه وقدم له رياض العبد الله، درا

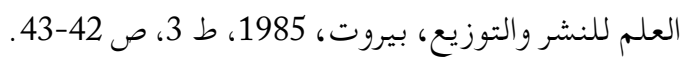

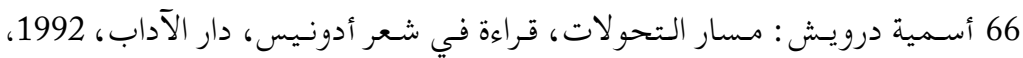

$$
\text { ط 1 128 ص ص } 228
$$

$$
67 \text { هنري كوربان : الخيال الخلاق في تصوف ابن عربي، ص الله حمادي : أنطق عن الهوى، ص } 145 .
$$


69 محي الدين ابن عربي : فصوص الحكم، ج 1، ص 329. 70 علي آيـت أوشـان : الذاكرة والصورة، قراءات نقديـة في الشعر المغربي المعاصر، .98

71 عبد الله حمادي: أنطق عن الهوى، ص 24.

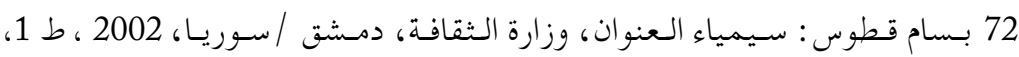
ص

73 عبد الله حمادي : أنطق عن الهوى، ص 32-33 ألمان. 74 أيمن حمدي : قاموس مصطلحات الصوفية، مع شرح اصطلاحات أهل الصفاء من كلام خاتم الأولياء، دار قباء، مصر، 2000، ص 52.

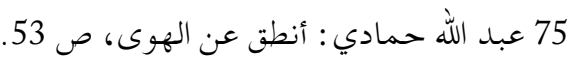

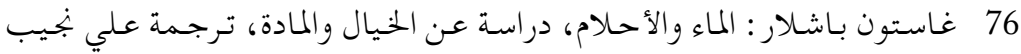

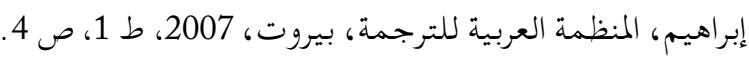
77 عبد الواسع الحميري: الذات الشاعرة في شعر الحمداثة العربية، المؤسسة الجمامعية

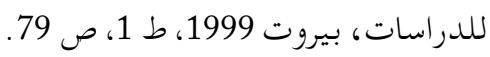

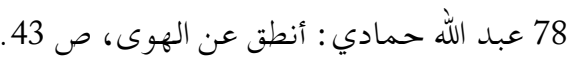
79 دافيد سنتيلانا: المذاهـب اليونانية الفلسفية في العالم الإِسلامي، تحقيق محمد جلال شرف، درا النهضة العربية، بيروت، 1971، ط 1، ص 105. 80 غاستون بشلار : الماء والأحلام، ص 9.

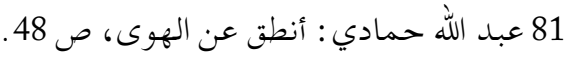

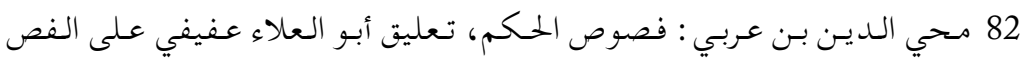
السادس،

83 عبد الله حمادي : أنطق عن الهوى، ص 79. 84 عبد العزيز بن عبد الجليل : الموسيقى الأندلسية، سلسلة عالم المعرفة، تصدر عن صن

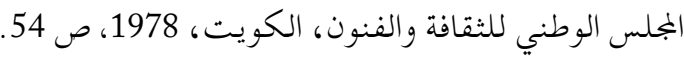


85 عبد الله حمادي : أنطق عن الهوى، ص 86

.Génette, G., op. cit., p.78. 86 


\section{CUESTIONES EPISTEMOLÓGICAS DE LITERA- TURA HISPANOARGELINA CONTEMPORÁNEA}

IsAaC DONOSO

Universidad de Alicante

\section{LA LENGUA ESPAÑOLA EN LA ARGELIA CONTEMPORÁNEA}

La presencia del castellano en el territorio de la actual República de Argelia constituye un episodio de la historia de la lengua española longevo, rico y heterogéneo. El español alcanzó dimensión de lengua universal con la colonización y administración del territorio americano, la ruta marítima del Pacífico y el comercio mundial desde Manila hasta Sevilla. Sin embargo, este expansionismo político, comercial y cultural de las élites cristianas ibéricas tenía como destino el norte de África, y allí se hubiera dirigido de no aparecer América. El descubrimiento de un continente virgen, y el paso directo hacia la ruta de China y la Especiería, relegaron a un plano completamente secundario los intereses mediterráneos. Mientras las élites gobernaban en encomiendas inmensos territorios en América y Asia, África fue el destino donde las masas espoliadas y expatriadas andalusíes fueron expulsadas, mudéjares y moriscos a los que les habían robado también la voz, y de arabófonos pasaron a ser hispanohablantes. De este modo comienza la historia del español en Argelia: destino poco deseado para las élites cristianas de España, depauperados moriscos, cautivos, renegados y misioneros.

Desde el siglo XVI, el español ha sido una de las lenguas escuchadas y habladas en Argelia, con numerosos acontecimiento y fenómenos lingüísticos en mayor o menor medida estudiados: 
lengua de moriscos, lengua franca, escritura aljamiada, influencia en el árabe argelino, formación de un español argelino, patrimonio inmaterial, fuentes históricas sobre Argelia, prensa argelina en español durante los siglos XIX y XX, etc ${ }^{1}$. En efecto, el fenómeno de la prensa escrita en español representa un corpus de material valiosísimo que seguramente no ha sido explotado en todas sus posibilidades. El estudio pormenorizado de estos textos nos ilustrará, muy seguramente, sobre una vitalidad cultural hispanoargelina no demasiado alejada de la francoargelina para comienzos del siglo XX.

A pesar de la pérdida de soberanía directa desde 1792, la colonización francesa motivó la migración de miles de españoles, que hicieron florecer de nuevo - como en siglos anteriores durante los protectorados, presidios y soberanía de numerosas plazas argelinas ${ }^{2}$ - el uso del español, sobre todo en la zona de Orán:

El español prevalecía sobre el francés en Argelia occidental. Se hablaba en la calle, en los centros laborales y recreativos, en familia y hasta en los organismos públicos, de forma que alguien llegó a lamentar que el idioma de Molière hubiese quedado circunscrito poco menos que a los impresos oficiales ${ }^{3}$.

${ }^{1}$ Seguramente sería necesaria una revisión general de la historia cultural de la lengua española en Argelia similar a la realizada genialmente para la población morisca en Túnez por Míkel de Epalza y Abdel-Hakim SlamaGafsi, El español hablado en Túnez por los moriscos (siglos XVII-XVIII), Valencia, Universitat de València, 2011. Como principal referencia véase Lamine Benallou, L'oranie espagnole. Approche sociale et linguistique, Orán, Dar El Gharb, 2002.

${ }^{2}$ Véase a título de información Rafael Gutiérrez Cruz, Los presidios españoles del norte de África en tiempo de los Reyes Católicos, Melilla, Consejería de Cultura, Educación, Juventud y Deporte, 1997; y Pedro-Alejo Llorente de Pedro, El penitenciarismo español del antiguo régimen aplicado a su presidio más significativo: Orán-Mazalquivir, Madrid, Ministerio del Interior, 2005. 
Junto a las variantes bereberes, el árabe dialectal y clásico y la ingeniería cultural de la introducción del francés, el español puede considerarse en propiedad lengua argelina, lengua romance que hereda el latín que un día se hablara en Numidia, y que tiene la doble filiación andalusí y española ${ }^{4}$. Y lengua sin duda materna o aprendida para miles de personas a lo largo de la historia moderna del país. La variante argelina de la lengua española posee sin duda uno de los decursos diacrónicos más originales dentro de la historia lingüística, por las diferentes etapas y transformaciones que ha tenido que sufrir. Su compleja existencia se refleja en la variante residual que se extingue en las últimas décadas, sobre todo en el español oranés, $y$, con mayor permanencia, en la influencia hispánica en las hablas argelinas 5 .

${ }^{3}$ Juan Bautista Vilar, Los españoles en la Argelia francesa (1830-1914), Madrid, CSIC, 1989, p. 322.

${ }^{4}$ Para una visión panorámica de las relaciones hispánicas con Argelia y, en general, con todo el Magreb, pueden consultarse las obras publicadas, hace ya algunos años, por la Fundación Mapfre en su Colección 1492: Mercedes García Arenal y Miguel Ángel de Bunes, Los españoles y el norte de Africa. Siglos XV-XVIII; Juan Bautista Vilar y Ramón Lourido, Relaciones entre España y el Magreb. Siglos XVII y XVIII; José Fermín Bonmatí, Españoles en el Magreb. Siglos XIX y XX; y Víctor Morales Lezcano (coord.), Presencia cultural de España en el Magreb.

${ }^{5}$ Sobre la situación actual del español en Argelia, véanse los escritos de Francisco Moreno Fernández: "El español en Orán: notas históricas, dialectales y sociolingüísticas", en Revista de flología española, 1992, tomo 72, fasc. 1-2, 1992, pp. 5-36; "El español en el mosaico lingüístico del Magreb”, en Cuadernos Cervantes de la Lengua Española, 1995, núm 3, julio, pp. 9-16; "Debilitamiento de -s en el español de Orán: análisis de sus contextos fónicos”, en Boletin de la Academia Puertorriqueña de la Lengua Española, 1994, núm. 1, pp. 91-111; y "El español en el norte de África (con especial referencia al español en Argelia)", en Celia Casado (ed.), La lengua y la literatura españolas en Africa, Madrid: Ministerio de Educación y Cultura y Melilla: V Centenario de Melilla, 1998, pp. 187-201. Sobre la influencia del español en las hablas argelinas véase Lamine Benallou, Dictionnaire des hispanismes dans le parler de l'Oranie. Argel, Office des Publications Universitaires, 1992. 
Al lado de estos dos fenómenos lingüísticos (desarrollo de una variante argelina del español e influencia hispánica en las hablas argelinas) hay que señalar un tercer aspecto que, en Argelia, como en el resto del mundo, se ha incrementado en las últimas décadas: el auge del español como lengua extranjera. Si en regiones alejadas tanto geográfica como culturalmente de España y el mundo hispánico la enseñanza del español como lengua extranjera crece, en un país como Argelia, a escasos kilómetros de la costa alicantina y con una relación cotidiana, es razonable que el Hispanismo goce de buena salud. En cualquier caso, por razones históricas de indudable peso, el español está llamado a ser lengua necesaria en la construcción argelina:

Además de ser una lengua de cultura y apertura hacia España y América Latina, representa un instrumento de conocimiento imprescindible para la investigación científica y el descubrimiento de datos e informaciones sobre la Historia de la época moderna de Argelia. Lo cual pone de relieve el interés fundamental que abarca la enseñanza del español en Argelia, enseñanza que debe privilegiar la práctica del idioma castellano que ha de conquistar más espacio pedagógico en las instituciones secundarias y universitarias, puesto que la historia moderna de Argelia está escrita en español y en osmani (turco antiguo), y yace en los fondos de archivos españoles. Creo que es de suma importancia, interesarse todavía mucho más por el español, difundirlo para que sea la vanguardia de las futuras generaciones, adaptándolo así a las realidades socioculturales de ambos países ${ }^{6}$.

${ }^{6}$ Ahmed Abi-Ayad, "El hispanismo argelino: importancia y perspectivas", en Florencio Sevilla y Carlos Alvar (eds.), Actas del XIII Congreso de la Asociación Internacional de Hispanistas. Madrid, 6-11 de julio de 1998, Madrid, Castalia, 2000, vol. IV, p. 38. 


\section{CONCEPTO DE LITERATURA HISPANOARGELINA}

Resulta cuando menos sorprendente el interés bibliográfico que ha suscitado y suscita la cultura hispánica en Marruecos, sobre todo en su vertiente de literatura marroquí en lengua española, así como la literatura morisca tunecina, en comparación con los escasos estudios sobre la producción literaria hispánica en Argelia. Es cierto que la presencia política española en Marruecos fue directa en la primera mitad del siglo $\mathrm{XX}$, y que la participación marroquí en la vida española suscitó el desarrollo de herramientas culturales, institucionales y educativas. Un fenómeno similar no pudo tener lugar en Argelia, sobre todo por las limitaciones de la acción política. Pero sí existió una altísima migración española que fomentó el asociacionismo, la organización y la publicación de materiales concernientes a la vida cotidiana de la comunidad española en Argelia. Y anteriormente había existido una presencia directa en Orán desde 1509-1792 (con un escaso cuarto de siglo XVIII en manos otomanas). Es de entender por consiguiente que población autóctona también accedería al uso de la lengua española, sobre todo dentro y en los alrededores de los presidios y plazas españolas, también por el contacto regular con moriscos españoles. En época decimonónica y finisecular los nuevos contingentes migratorios ayudarían a preservar e incrementar el fenómeno con la prensa escrita. En resumen, si no al nivel de Marruecos, sí existen materiales dispersos, en la prensa periódica, en impresos y hojas sueltas, en manuscritos que nunca vieron la luz, en relaciones de sucesos y crónicas, loas, poemas, y en la propia literatura española escrita en torno a Argelia, comenzando por Miguel de Cervantes. Desde Diego de Haedo hasta la actualidad, sin duda hay materiales para dar forma a una «Literatura hispanoargelina», o bien a una «Literatura argelina en lengua española».

El concepto «Literatura hispanoargelina» emula otros conceptos actualmente en uso y con trayectoria bibliográfica plena- 
mente constituidos, sin duda los tradicionales «Literatura hispanoamericana» y «Literatura hispanofilipina», pero también, y con mayor sentido, los de otras literatura magrebíes en español que quizá han gozado de mayor fortuna bibliográfica, a saber: «Literatura hispanomarroquí» ${ }^{7}$ «Literatura hispanotunecina». El par «hispano-marroquí», si usado en numerosas ocasiones, viene a reflejar no una consumación sintética y hegeliana, sino más bien una bipolaridad amorfa y en muchos aspectos antinatural, de una cultura no bien resuelta y constituida, y haciendo uso de un equívoco nacido de la política que no es aplicable al continuum cultural. Por lo tanto, desde un punto de vista hispanohablante y ateniendo a la bibliografía consolidada en lengua española y para un público lector en esta lengua, es posible categorizar "Literatura hispanoargelina", entendiendo la producción literaria argelina en lengua española y, en un sentido extenso y auxiliar, la producción española que se produjo en las antiguas posesiones españolas en el actual territorio de la República de Argelia, o que tratasen sobre las mismas ${ }^{9}$.

Otro concepto diferente, más perifrástico pero seguramente más preciso, es el de "Literatura argelina en lengua española",

${ }^{7}$ Ana Rueda (ed.), El retorno/el reencuentro: La inmigración en la literatura hispano-marroqui, Madrid, Frankfurt, Vervuert, 2010. Existe ya a día de hoy una larga nómina de obras que tratan de forma general y a modo de manual el fenómeno de la literatura marroquí en español, por ejemplo: Mohammad Chakor (ed.), Encuentros literarios. Marruecos-España-Iberoamérica, Madrid, CantArabia, 1987; y Carmelo Pérez Beltrán (ed.), Entre las 2 orillas. Literatura marroqui en lengua española, Granada, Editorial de la Universidad de Granada, 2007.

${ }^{8}$ En su aspecto literario, sin duda la obra que formaliza el concepto es la de Luis F. Bernabé Pons, El Cántico islámico del morisco hispanotunecino Taybili, Zaragoza, Institución Fernando E1 Católico, 1988.

${ }^{9}$ Por ejemplo véase Nordin Malki, Historiografía española del siglo XVI sobre historia de Argelia: Mármol, Haedo y Suárez, Orán, Universidad de Orán, tesis de máster, 1987. 
entendiendo la ideación de una idea de "Literatura argelina" como hecho fundamental y, en el caso particular, atendiendo a la producción en lengua española. La española sería una más de las posibles producciones literarias con naturaleza dentro de una idea de "Literatura argelina", como literatura canónica, nacional e histórica de los pueblos de Argelia, una más junto a la bereber, árabe o francesa. La estructura de este concepto también tiene tradición dentro de la bibliografía española, y puede hablarse, sobre todo en contextos donde la literatura en español no es la única producción nacional, de "Literatura filipina en lengua española", "Literatura marroquí en lengua española", o también y en nuestro caso, "Literatura argelina en lengua española". Consecuentemente, la construcción integral y comprehensiva del objeto de estudio sería posible, una idea, digamos achipelágica y comparatista, de "Literatura argelina", en sus principales manifestaciones lingüísticas: "en lengua árabe", "en lenguas bereberes", "en lengua francesa", y "en lengua española". Seguramente en el caso argelino sea necesario también un método intracomparatista, en donde las diferentes tradiciones escriturarias sean analizadas no como islas autónomas e independientes, sino formando parte de un todo archipelágico ${ }^{10}$. De este modo se obtendría una narración coherente del hecho argelino y se reconciliaría una literatura que, a día de hoy, sólo existe en parcelas lingüísticas, siendo una de las parcelas más ignoradas y marginadas la escrita en lengua española.

\section{RECONSTRUCCIÓN DE LA PRODUCCIÓN LITERARIA}

Bibliográficamente $y$, sin entrar en materia, es probable que la literatura argelina en lengua francesa haya adquirido una atención especial, tanto por parte de la historia como de la críti-

${ }^{10}$ Véase nuestra discusión para el caso filipino en "Intracomparatismo: E1 paradigma filipino", en Pedro Aullón de Haro (ed.), Metodologías comparatistas y Literatura comparada, Madrid, Dykinson, 2012, pp.527-533. 
ca literaria. La literatura argelina en árabe, sobre todo la moderna, seguramente ha sido mejor tratada que la antigua ${ }^{11}$. Y para la parte bereber, hay un campo disciplinar especifico que lleva trabajando en ello desde hace años, y es creciente el conocimiento que se tiene de la materia ${ }^{12}$. No obstante, lo que podemos constatar es que es necesaria una revisión bibliográfica exhaustiva que analice el estado de la cuestión y las lagunas que siguen existiendo, con el fin de obtener una imagen cabal, amplia y rigurosa del objeto de estudio, la "Literatura argelina" como un todo.

Pero ésta es una labor en la que ahora no queremos ni podemos adentrarnos, sino constatar que, para la reconstrucción del objeto, la producción en español significa una parcela seguramente ignorada, desatendida, incluso desde el Hispanismo y los hispanistas. Para formularlo en otra palabras, todavía no se ha asumido la posible y necesaria conceptualización de una "Literatura hispanoargelina”, más antigua y más compleja que la propia "Literatura hispanomarroquí", que pueda ofrecer otras claves para entender la naturaleza y desarrollo de la Argelia moderna:

De manera general, el hispanismo en Argelia sigue confinado dentro de unas fronteras que no ha podido superar, o mejor dicho, no ha sabido ensanchar a otros campos, ya que sigue preso de ciertos límites temporales y geográficos que

${ }^{11}$ Donde es probable que siga siendo válida la visión general ofrecida por Šawqī Dayf, Tārīj al-abad al-'arabī. Așr al-dawal wa-l-imārāt. al-Ŷazā'ir, alMagrib al-Aqșà, Mawrītānyā, al-Sūdān, Beirut, Dār al-Maārif, 1995, pp. 19251.

12 Por ejemplo Lamara Bougchiche, Langues et littérature berbères des origines à nos jours, París, Ibis-Press 1997. Hay que destacar en España la labor realizada por la Universidad de Cádiz en el fomento de los Estudios Bereberes. 
podemos palpar a través de sus temas de predilección: los temas históricos, sobre todo el interés por el siglo XVI. ${ }^{13}$

A pesar de la buena salud del Hispanismo argelino, es necesario por lo tanto que se planifiquen las grandes obras todavía por escribir y necesarias para una bibliografía argelina moderna, ya no sólo desde un punto de vista hispánico, sino desde la propia reconstrucción de la nación argelina, desde una Historia cultural de la lengua española en Argelia, a una Literatura hispanoargelina, terminando por una Historia General de las Letras Argelinas.

En este sentido, ya no hay que tener en cuenta únicamente el reducido porcentaje de población argelina hispanohablante, sino los quinientos millones de hispanohablantes del mundo y la riqueza de la bibliografía en español en cantidad y calidad. Tanto la escritura como la traducción en español deben de ser entendidas no en su mercado local, sino dentro del mundo global en el que vivimos, inmediato y universal:

En el mundo árabe, si la traducción en árabe está en aumento con un 5 por ciento de la edición global (Jacquemond, 2012: 3), las traducciones al español siguen muy marginales; cabe recordar que los hispanohablantes en Argelia no representan más de 0,16 por ciento de la población según el dato ofrecido por Humberto López Morales (2012: 20). Este dato reviste una gran importancia y explica la falta de traducciones en Argelia al español, ya que a nivel lucrativo no puede ser tentador para las editoriales regidas y condicionadas por imperativos mercantiles, visto el reducido número de receptores en esta lengua, y de ahí la dificul-

${ }^{13}$ Nafissa Mouffok, "La traducción y el hispanismo argelino. Situación y perspectivas", en África con eñe. Index.comunicación: Revista cientifica en el ámbito de la Comunicación Aplicada, 2014, vol. 4, núm. 2, p. 50. 
tad para los hispanistas argelinos de lanzarse en esta empre$\mathrm{sa}^{14}$.

Lo mismo es necesario afirmar en sentido inverso. El Hispanismo argelino tiene obligaciones que acometer para con la sociedad, cultura e historia de Argelia, del mismo modo que el Arabismo español debería de atender el abandono al que tradicionalmente ha relegado los asuntos argelinos. Estado de abandono que puede constatarse en las obras argelinas traducidas al español, y cuyo panorama, trazado hace ya bastantes años por Pérez Cañada, nos tememos que sigue siendo válido ${ }^{15}$. Ésta era la crítica que realizaba Nafissa Mouffok en torno a la poca claridad y consistencia de una idea de "Literatura argelina" por parte de la crítica y la recepción españolas:

Lo expuesto anteriormente muestra que el interés por la producción argelina en árabe sigue bastante débil y que las elecciones de las obras no parecían seguir un criterio de selección claro; la traducción de los poemas de Abdallah Hammadi, por ejemplo, se realizaron por el simple hecho de haber residido el autor en España ${ }^{16}$.

Y esto nos lleva a Abdallah Hammadi, autor de excepcional importancia en la historia moderna de la cultura argelina, poeta, crítico literario, historiador de la cultura, filólogo, traductor, y el único argelino que ha recibido el prestigioso premio literario Babtain, pero que, sorprendentemente, ha pasado desapercibido

${ }^{14}$ Ibid., p. 56.

${ }^{15}$ Luis Miguel Pérez Cañada "Panorámica de los estudios y traducciones de literatura argelina en español”, en Gonzalo Fernández Parrilla, Luis Miguel Pérez Cañada y Rosario Montoro Murillo, Panorámica de los estudios y traducciones de la literatura del Magreb en español, Toledo, Escuela de Traductores de Toledo, 1998, pp. 17-26.

${ }^{16}$ Nafissa Mouffok, loc. cit., p. 55. 
en su faceta de escritor argelino en lengua española. $Y$ aquí hay que ir por partes, pues nos parece que la voluntad de Nafissa Mouffok era resaltar el poco criterio con el que se atendía en España la literatura argelina, seleccionando a autores por el mero hecho de su residencia en el país. Si bien en muchos casos ésta puede ser una práctica general, en este caso concreto se daba la circunstancia de que Abdallah Hammadi era un prominente escritor en árabe y, como se demostró después, un magnífico escritor en español. Hasta donde nosotros sabemos, en este punto quedó el conocimiento que se ha tenido en España sobre Abdallah Hammadi, como poeta argelino en lengua árabe del que Serafín Fanjul tradujo unos poemas, con criterios supuestamente poco rigurosos, en los años setenta ${ }^{17}$.

$\mathrm{Y}$ parece absolutamente sorprendente que la ingente labor, prolija producción y valor estético y literario de la obra de $\mathrm{Ab}-$ dallah Hammadi no haya suscitado mayor interés, ya no sólo por parte del Arabismo español, sino por toda una Filología Hispánica, que se vanagloria por su vocación universalista. Y es que el Hispanismo español, al igual que la escasa atención dada a la lengua y literatura españolas en Argelia, no ha reconocido hasta el momento el papel jugado por Argelia y Abdallah Hammadi en el concierto mundial de las literaturas hispánicas.

Nos parece por lo tanto de urgente necesidad la reconstrucción de una "Literatura hispanoargelina" que destaque la figura de Abdallah Hammadi en la conformación de sus épocas contemporánea y actual, y como valedor de un hecho cultural permanente y diverso en la historia argelina: la herencia andalusí, la vocación mediterránea y el contacto humano entre las dos orillas.

${ }^{17}$ Serafín Fanjul, "Un poeta argelino en España: 'Abdallāh Ḥammād̄̄”, en Almenara, 1975, núms. 7-8, pp. 313-324; y "Jóvenes poetas árabes en Madrid: Abdallāh Ḥammādī”, 'Abd al-Karīm al-Hūlī, Aḥmad 'Abd al-'Azīz, Ramzī Darwīš y Șìmūn al-Dā’irī”, en Almenara, 1976, núm. 9, pp. 203-216. 
Junto a la figura de Abdallah Hammadi, sería necesario, para reconstruir una "Literatura hispanoargelina contemporánea", indagar, rebuscar y recuperar textos dispersos. Probablemente no será mucho lo que aparezca, pero los pocos materiales que se pongan en común conformarán un panorama valioso, bien por su faceta literaria, bien por constituir una tradición centenaria en Argelia que se remonta al mismo Miguel de Cervantes. Como textos susceptibles de una revalorización a la luz de su aportación a la construcción de una literatura argelina en lengua española, podremos encontrar, sobre todo, publicaciones literarias o académicas de hispanistas o arabistas argelinos, textos, muchas veces caseros en papeles grapados, en revistas de escasa tirada y distribución, o autopublicaciones. En cualquier caso la consigna debe de ser atender al esfuerzo intelectual desarrollado en Argelia a favor de la lengua española, y revalorizarlo en un contexto de literatura hispanoargelina. Una literatura necesaria en la explicación de la naturaleza y la identidad argelinas, abierta a quinientos millones de lectores. Forzosamente hay que superar por lo tanto el ámbito de la recepción local, para, a través de la lengua española, hacer universal el mensaje del pueblo argelino.

Como apéndice a este texto epistemológico que pretende esbozar las parámetros conceptuales de una "Literatura hispanoargelina”, nos gustaría realizar, a modo de ejemplo, una breve antología por géneros de pequeños textos. Su fuente sobrevive en el Seminario de Estudios Árabes e Islámicos de la Universidad de Alicante gracias a la labor de Míkel de Epalza durante los primeros años de la década de los setenta del siglo pasado en universidades argelinas. Se trata de dos ejemplares de la revista literaria Altavoz. Literatura y expresión española, publicada por la Universidad de Argel y correspondientes a sus números 1 (1971-72) y 3 (1973-74). En ella aparecen tanto textos de creación como ensayos y artículos, dando un panorama, breve, pero 
completo, de la diversidad de géneros y temas. Son sobre todo los géneros ensayísticos los que más abundan, y revistas como Oussour al-Jadida, revista científica editada por el Laboratorio de investigación en Historia de Argelia de la Universidad de Orán, publican regularmente artículos en español ${ }^{18}$.

En fin, una labor exhaustiva de rastreo e investigación pondrá en común una serie de materiales, seguramente no valorados en su verdadera importancia, a saber, la de constituir una tradición uniforme en el tiempo y heterogénea en su naturaleza, que no ha sabido o no ha podido visibilizarse conceptualmente como parte consustancial de la idea de "Literatura argelina". Una producción en español que, argelinos, de adopción o nacimiento, de diferentes épocas y por diferentes motivos, han sentido la necesidad de escribir, y que, sin ser nada sorprendente, se mantiene en la actualidad. Lo sorprendente del hecho es la poca atención que el fenómeno literario hispanoargelino ha despertado, de ahí la reivindicación epistemológica que hemos querido realizar, a la luz del magisterio y ejemplo de Abdallah Hammadi.

${ }^{18}$ Por ejemplo para el número 11-12 correspondiente a los años 201314, se publicaron cuatro artículos en español: Habib Attalah, "Introducción al comienzo del malikismo en Ifriqiya y al-Andalus", pp. 5-14; Fouad Kebdani, "Argelia a través de la mirada de Paul Balta", pp. 16-34; Lahouaria Nourine Elaid, "Argelia y la expulsión morisca", pp. 35-42; Mustapha Bedai, "Orán y los españoles en la bibliografía local”, pp. 70-74. La regularidad y consistencia de esta revista hace que, manifiestamente, merezca un estudio particular, una relación de sus publicaciones en español, y una valoración de su contribución al conocimiento de Argelia, sobre todo en su clave hispánica que $\tan$ bien cultiva. 
IV. BREVE ANTOLOGÍA DE LA LITERATURA HISPANOARGELINA CONTEMPORÁNEA

a) Poesía:

\section{CUERPO CELESTE}

Niño, te canto tiernamente

Porque hay algo en ti

Que no es de la tierra.

Cuando te miro, siempre

Recuerdo algo irreal,

Porque te escapas, y los sentidos

No pueden captarte en tu totalidad.

Niño, ¿qué es este regalo

Que te hizo algún hada?

¿Qué es exactamente lo que te diferencia de nosotros?

Eres inmenso y pequeño,

Inocente y sabio,

Hay algo en ti que evoca el cielo,

Algo que no se puede definir,

$Y$ que constituye tu secreto íntimo

Que acaso nunca conozcamos de verdad

\section{Zohra Cherief}

EN EL SAHARA

Oasis

Oasis, oasis, 
Dame un poquito de agua,

Fresca o caliente.

No por la sed que tengo,

Sino por verte,

Sino por verte, alma del Sahara,

Sino por verte.

Dame unos pocos dátiles,

No por el hambre que tengo,

Sino por verte,

Sino por verte, oasis,

Sino por verte, en el corazón

Del Sahara.

\section{La ciudad}

Sola,

Como una isla

En un mar de arena.

Sola,

Como un náufrago

Sobre las olas.

Sola,

Como un huérfano

En el mundo.

Sola,

Como el sol

En el azul del cielo

Acoges al viajero

¡Oh, ciudad del Sahara! 


\section{EMOCIÓN DE REBELDÍA}

\section{En memoria de una compañera}

¡Ay pérdida fatal de un brío primaveral!

Camino predestinado: ¡qué emoción silenciosa!

Calor, luego frío; material; luego, vacío;

visible; luego, invisible;

silencio indefinido, desconocido...

Sombra sin voz, sombra sin cuerpo,

la imagen del suspiro nostálgico

aletea en cada corazón que arde

de vida. Vida de primavera.

Lágrimas frente a la inmensa nada.

Tumba en donde se desmorona la vida, tumba en donde se embellece la muerte.

E1 dolor del recuerdo juvenil es el polen de un tiempo sin olvido. Tiempo de inocencia.

Lamentaciones frente a la suprema indiferencia.

Flor humana, como la pálida rosa llorosa,

has exhalado una esperanza sin color

en las miradas de las futuras víctimas.

Flor humana, ya sangre telúrica, en tu perfume inodoro pervivirán las reminiscencias de rebeldía.

Argel, 19 de febrero de 1974

\section{Ahmed Berraghda}




\section{ESTRIBILLO DE AMOR}

Como el sol en el universo, estás en mi sueño; como la sangre en mi organismo, estás en mi esperanza; como la luna en la noche, estás en mi tristeza; como la primavera en la huerta, estás en mi alegría; como la llama en la paja, estás en mi ansia; como la gacela en el Sahara, estás en mi soledad; como el núcleo en el átomo, estás en mi alma; como Dios en la religión, estás en mi espíritu; como la escultura en el mármol, estás en mi memoria;

como la savia en la planta, estás en mi sensibilidad; como el agua en la tierra, estás en mi vida; como el aire en los pulmones, estás en mi aliento; como la estrella en el cielo, estás en mi sombra; como la pupila en el ojo, estás en mi mirada; como el grano de polen en la flor, estás en mi existencia;

como el viento en los veleros, estás en mis caminatas;

como el pavo real en el jardín, estás en mi amor; como el tic-tac en el reloj, estás en mi corazón; como la letra en el idioma, estás en mi poesía; como Leila en kais, como Leonor en Machado, como Elsa en Aragón, estás en mí, ¡oh, morenita!

\section{Ahmed Berraghda}




\section{Tú SUEÑAS}

En el jardín de tus sueños

He pasado el otro día

Minutos breves.

Allí he cogido

Un trozo de plata de tu velo

Y lo he prendido en la estrella

Que titilaba

Tú soñabas.

Soñabas sin poder oír

El canto de esa gotita de luz tierna

Que te mecía.

Tú soñabas,

Soñabas con esas cosas extrañas

O más bien con el ángel encantador

Que sonreía.

Tú soñabas.

Entonces, en la noche y su penumbra,

$\mathrm{Vi}$ de tu sueño la sombra

Que te evadía.

Tú soñabas.

$Y$, cuando la aurora rosada

Rozaba con su ala la rosa

Que despertaba,

Tú, tú... ¡Soñabas! 
b) Prosa:

Zohra Cherief

\section{LA MUJER FRENTE AL MAR DESNUDO}

El mar tiene sobre nuestros ojos poder de sortilegio. ¿No sabemos acaso que, sentados a su orilla, se nos pasan las horas contemplándolo? ¿Qué hay de femenino en el contorno de su ola? ¿Que hay de oferta, de entrega, de caricia, de seducción femenina en su movimiento? ¿Y qué extraño misterio el de nuestra soledad cuando nos apercibimos que también está el mar desnudo y solitario? Preguntádselo a Juan Ramón del "Diario de poeta y mar":

En ti estás todo y, sin embargo,

¡Qué lejos sin ti estás, qué solo!

Qué lejos siempre de ti mismo

Abierto en mil heridas cada instante

Cual mi frente.

Tus olas van como mis pensamientos

$Y$ vienen, van y vienen,

Besándose, apartándose en eterna conocerse,

Mar, y desconocerse.

Eres tú y no lo sabes.

Tu corazón te late y no lo sientes.

Qué plenitud de soledad, mar solo.

Mar... Mujer... ¿Qué os une y fusiona así?

Afrodita, recién surgida del Océano, invente la coquetería. Desde la impresionante melena del León, el multicolor plumaje del Pavo Real o del Ave Lira, se extiende toda la gama de atrac- 
tivos con que la naturaleza adorna al elemento masculino de cada especie (excepto los insectos). Manchas, soberbios penachos, crestas y excrecencias variadas deslumbran a la hembra y afirman la preponderancia del elemento activo de la Creación. ¿En qué día del Génesis o del Mito rompe la especie humana esta norma? ¿En qué momento Afrodita, recién surgida del Océano, inventa la coquetería? ¿Cómo, cuándo y por qué aparece este primer movimiento de liberación femenina?

Así, una Eva solitaria encuentra, en la fina arena de una playa sin estrenar, la primera concha, el primer guijarro, el primer esqueleto vegetal policromo. Está naciendo una técnica sutilísima de seducción, un lenguaje cifrado, un simbolismo que permanecerá, grabada en lo profundo del Inconsciente Colectivo. Esta mujer que, en el limite de las aguas y las tierras se adorna con los elementos materiales más simples (piedras, vegetación), esta mujer que protege su nariz con las conchas nacaradas de un molusco cualquiera, que cuelga de sus orejas fragmentos de sal cristalizada, que busca, prudente, entre los residuos de la última tempestad, madréporas, estrellas de marino, ¿revoluciona con su gusto el orden establecido?

Ha nacido frente a la necesidad básica, la selección artificial. Frente a la fuerza ciega reproductora, un matiz de brillos, oropeles, afeites, modas, perfumes y sutilezas que convierten al macho de buscado en buscador, de epicentro en galán que ronda. Ha nacido el artificio, simple como todo lo que perdura, elemental como las verdades.

Es el guijarro que será gema, la vulva que será perla. Coral de pulseras, zarcillos y brazaletes. Alga de futuras diademas. Ha nacido sin saberlo o sabiéndolo, la Belleza Femenina frente al mar desnudo, $y$ ha nacido también su cambiante y movedizo concepto. Hay, en el límite del agua y la tierra, un canon incipiente. 
Todo está aquí: las antiguas magias lustrales están, y la base económica de los pueblos que hicieron moneda de las conchas calcáreas, y el rito del árbol surgido de profundidades abisales, y el primer espejo narcisista que el resto de los vertebrados no ha comprendido y que les insectos con sus ojos poliédricos no pueden ver.

Pero el mar... el mar es algo desnudo. Hay un viejo decir de Xenius cuando era joven, en el que explica que se acercó a su mar de Barcelona y le pareció entero y siempre fiel a sí mismo. Queréis oírla esa vieja "Glosa del Xenius" de 1917?
$¿$ Quién vio mayor desnudez?
Más sincera - Más severa
Más pura - Más segura
Que la desnudez del mar?
Allí estaba ella sola
En la tarde que moría
Sola pena que rodaba
Su gran clamor sin palabras.

"Todo se puede disfrazar - termina Xenius- menos el mar, la lenta fatiga del mar, el lento empuje del mar".

¿Fue una intuición de la mujer? ¿Fue una creación del hombre? El mar recuerda a la mujer y con ella y el mar la Belleza está aquí, entre nosotros, como un concepto y un condicionamiento. Como un acto automático, reflejo espontáneo. Cama una realidad, como una llamada, como una obligación agradable y maravillosa.

Pero la Mujer esta sola en la playa. Tiene en una mano el futuro laurel para el vencedor, el ramo de olivo para la paloma Noé, la rama de encina de las druidas, el espantajo de la mandrágora, el livor de los marfiles, la esencia de la esposa de "El Cantar de los cantares”, el cloro de los verdes jardines edénicos. 
Sueñan en su mano los pólenes submarinos que fecundan el depósito de alimentos mas gigantesco del planeta.

\section{EDITORIAL}

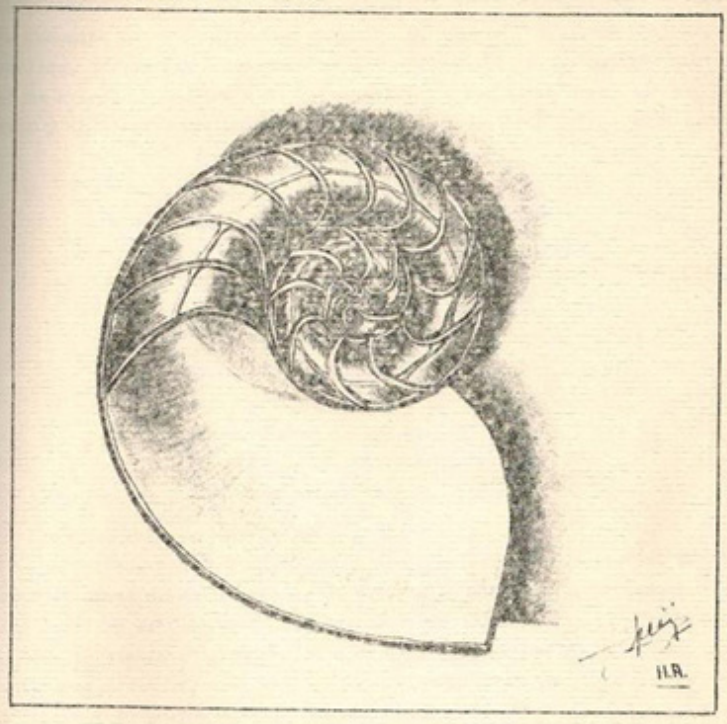

LA MUUER FRENTE AL MAR DESNUDDO

\section{CHÉRIEF ZOHRA}

Portada original del relato "La mujer frente al mar desnudo", de Zohra Cherief 
c) Ensayo:

Zohra Cherief

\section{POESÍA CABILEÑA DE TRADICIÓN ORAL: SI MO- -HAND OU MEHAND}

La finalidad que nosotros nos proponemos es modesta: verter alguna claridad sobre determinados aspectos de la vida literaria.

Existe en Cabilia un nombre venerado por nosotros, es el del poeta SI MOHAND o MEHAND de ATH-IRATHEN. Su obra fue transmitida por un pueblo analfabeto, cuya lengua no se escribía entonces. Estos poemas nos llegaron en forma de melodías y cantos que se transmitían de madres a hijas, y de refranes que se citaban a menudo en las conversaciones entre hombres.

Se cuenta que un día se le apareció un ángel y le dijo: "Rima y hablaré, o hablo y rimarás". Si Mohand escogió la palabra. La tradición oral nos explica así cómo compuso rimas divinas, aunque su solo fin fuera expresar sus propios tormentos. No se conoce exactamente el número de versos y poemas que declamó, porque muchos se perdieron. Sin embargo, los isefra (poemas que se pueden reducir a refranes) que han llegado hasta nosotros, constituyen una colección bastante rica.

Define su poesía con estos versos:

Thikelta ad hhedjigh asfrou

Oua lahh addihhou

Addinaddi ddeg londdiath. 

Oui thislan ar dda thiarou
Our as iverou
Oui lan ddelfahhem izrath.
Éste es mi poema
¡Ojalá sea bello
Y se propague por doquier!
Quien lo entienda lo escribirá,
No lo olvidará
Y el sabio me aprobará.

El poeta hablaba, y el viento sembraba sus versos en el eco del tiempo. Sus contemporáneos no se preocuparon de recoger las rimas de esta caprichosa inspiración. Pero hubo imitadores, y así se celebraban veladas poéticas para que cada cual declamara sus composiciones.

A principios de siglo, Boulifa espigó algunas de ellas, sobre todo las isefra de Si Echand. Pero la obra de Boulifa trata más bien de geolologia, porque esta precedida de un importante estudio de la tradición oral cabileña, y desarrolla mas ampliamente el tema de la misión de la mujer en la familia, en el clan o la tribu.

Publicada en 1900, esta "Compilación" de poesías cabileñas contiene la mayor parte de la obra de Si Mohand. Se conserva este libro como el doble infalible de una memoria sujeta al olvido. Para nosotros, jóvenes cabileños constituye un tesoro que contiene y guarda celosamente la esencia de nuestra poesía. Cada pueblo tiene el suyo, escrito sobre pergamino, venerable, tal y como fue editado hace mas de medio siglo.

Boulifa recogio 300 isefra, las demás han llegado hasta nosotros gracias a discípulos o imitadores anónimos de Adeni que editaron ulteriormente el Libro de Si Mohand menos conocido. 


\section{Alma del poeta}

Nació Si Mohand en el pueblo de Tizi-Rached. Es un poeta errante. No canta solo en las plazas públicas ni en los cafés. No profana su arte, no quiere convertirlo en comercio. Era el trovador apasionado del espacio y la libertad, guiado por su estrella. Se paraba en los sitios agradables, recorría la pequeña y la gran Cabilia. Viajó por Argelia y conocía casi toda Tunicia.

No vacilamos en llamarlo Poeta del Amor y de las Musas Eróticas. Era un ídolo de los jóvenes, cuyos sufrimientos y sentimientos sabía expresar y cantar.

A pesar de $1^{\mathrm{a}}$ partícula "Si" que precede a su nombre, no descendía de morabito. Este título de distinción, de respeto, le fue otorgado por su padre, que era letrado y sabio. Desde joven iba a la zaouia para aprender el árabe. $\mathrm{Al}$ morir su padre, debe abandonar los estudios. Suelta las riendas y se embriaga con su juventud, sus aspiraciones, sus sueños y su arte. Su sensibilidad le inicia al misterio de la Naturaleza y le hace ver la riqueza que encierran las criaturas. Pero después experimenta sentimientos amargos. Por haberse apartado de la vía que le había trazado su padre y por haber dejado de estudiar el Alcorán, implora perdón a Dios y llora en sus poesías.

Para completar este retrato, voy a citar varios testimonios. Si Yousef, poeta de su generación (muerto en 1956 en Tourirt Amrane, con más de un siglo de edad), fue testigo de su vida. Su hijo Lefki pudo elaborar una biografía bastante fiel en 1947.

\section{Nacimiento y muerte}

Tengo que recordar al lector que en Cabilia no hubo registro civil hasta 1891, lo que explica el desacuerdo en cuanto a la fecha de su nacimiento. Pero Si Yousef habla de las "Cartas" que exis- 
tÍan anteriormente. Si Mohand nació hacia 1840. Sin embargo, todos están de acuerdo en cuanto a la fecha de su muerte: 1906 en el hospital de las Hermanas Blancas (Misioneras) de Michelet. Si Yousef dice: "Murió a los 63 años, a la misma edad que nuestro Profeta Sidna Mohamed. Lo repetimos todos aquel día”.

Su obra

Emplea siempre la primera persona: yo o nosotros. En su poesía se reflejan sus sentimientos, afectos, ira, tristeza u odio.

$\mathrm{Su}$ poesía brota de una larga experiencia, Las etapas de su obra corresponden a las de su vida, durante la cual alcanza la felicidad. Descubre que todo es incomprensión, maldad, y piensa que él mismo no es más que ilusión. Para él solo existe el Creador:

Tsekhilek a rebi ar kenghidd

Aqlu amin thenghidd

Ddidounith iounés naamis

Dios, apiádate de mí.

Soy aquél a quien quitaste la vida.

Y no espera nada de este mundo.

Los temas de su poesía

De joven, Si Mohand cantó mucho el Amor y la Esperanza, la Belleza. Hay que explicar la concepción particular del amor que tienen los cabileños. No se trata de ir al asalto de cualquier ciudadela, no se trata tampoco de seguir atentamente algún itinerario en "la Carte du Tendre", ni perseguir a una Eva vaporosa. Las costumbres son más rígidas. Hay que contener el ardor físi- 
co y tratar de ganarse a los padres para arrancarles el consentimiento de matrimonio. He aquí algunas manifestaciones de esto: "Hay que luchar como el rico que caza la tórtola, hay que adormecer al vigilante de las mozas inabordables?

Pero incluso cuando Si Mohand escribe sobre temas alegres, hay siempre tristeza, una sombra oscura en su poesía. ¿Por qué? Sus amigos lo explican diciendo que hablaba el poeta de un "mal" indefinido que lo volvía cada vez más seco. Así repite a menudo en sus poemas estos versos: "Un mal que toca mi corazón y lo endurece como piedra", "Soy ávido del amor de las jovencitas", "Mi confesión haría temblar al monte", "Mi mal me consume y me entenebrece", "Dios solo sabe de qué se trata".

Los cabileños hablan de los "espíritus perspicaces" que comprenden todo. Y lo que debemos notar aquí es que la sociedad era aún primitiva, con reacciones brutales que atribuyen mucha importancia a la virilidad. La potencia viril hace posible la posesión de la mujer, y al mismo tiempo da la fuerza muscular, la barba y el valor. Si no

posee estas cualidades básicas, el hombre es débil. Tal vez, según Si Yousef y los contemporáneos, una enfermedad secreta lo roe y consume poco a poco, como una candela que se apaga.

Así se explicaría la melancolía y la desesperanza que se adivina entre líneas.

Hay ruptura de armonía entre su persona física y su alma. Este espectáculo íntimo de desequilibrio, que no deja de verse y sentirse, explica toda la contradicción de su poesía. En la amistad no encontrará felicidad tampoco, porque su susceptibilidad hará de él un hombre suspicaz:
A rai iou avou thloufa
Theklddak Imairfa
Ithedoun dáour Thezzridd 

A ti, que buscas la prueba, la Amistad, ¿̇e habrá traicionado por tratarte con cualquiera?

Su idea de la amistad es afín a la de La Fontaine o Montaigne: Decía:

L'amitié est un trésor caché

Dont le malheur déchire le voile.

\section{La amistad es un tesoro oculto \\ Cuyo velo desgarra la desgracia}

La felicidad no está en la riqueza. Si Mohand busca lo Absoluto y lo Ideal. Para él, el Amor, la Libertad, la Amistad existen, pero no las podemos alcanzar. Ve y siente todo y, como el Eclesiastés dice: "Vanidad de vanidades, y todo es vanidad".

Es un hombre que encarna un mundo, un pueblo, una época. Un poeta auténtico que se asemeja a un espejo donde se reflejara nuestra alma.

Si Mohand es el portavoz de la generación traumatizada por las guerras, arrancada de las tradiciones, y cuyas estructuras sociales desaparecieron.

\section{1: Rebeldía}

Para el poeta, la conquista de la Cabilia significa la muerte de su padre, la ruina de la familia y la destrucción de su pueblo. Añora la época en que el cabileño era libre; pobre, pero digno, valeroso y honrado; justiciero. 
Dios y la fe

Recurrió a Dios, esperando en el más allá. Ya viejo, se preparaba a morir como un verdadero musulmán, cuya fe se funde con su espíritu.

Uno de sus últimos poemas, recogido en 1906 por el R.P. Giaccobetti, trata de su último viaje a Maison Carrée \& Michelet, donde muere.

Retraza las etapas de la vida; y constituye una noble invocación al Santo venerado de Michelet: el Jeque Mohand ou el Hocine, al que pide su viático para que vivan otras generaciones:

O Chikh Mohand ou el Hocine A el vaz izeddghan el hecin

Haqac ouisin Âtha iceehmu ousemidd

¡Oh, halcón que vives en las cimas!

Necesitas un compañero,

Mas yo siento ya el frío dentro de mí.

*Tomado de: Los poemas de Si Mehand Mouloud Feraoun, 1960. 


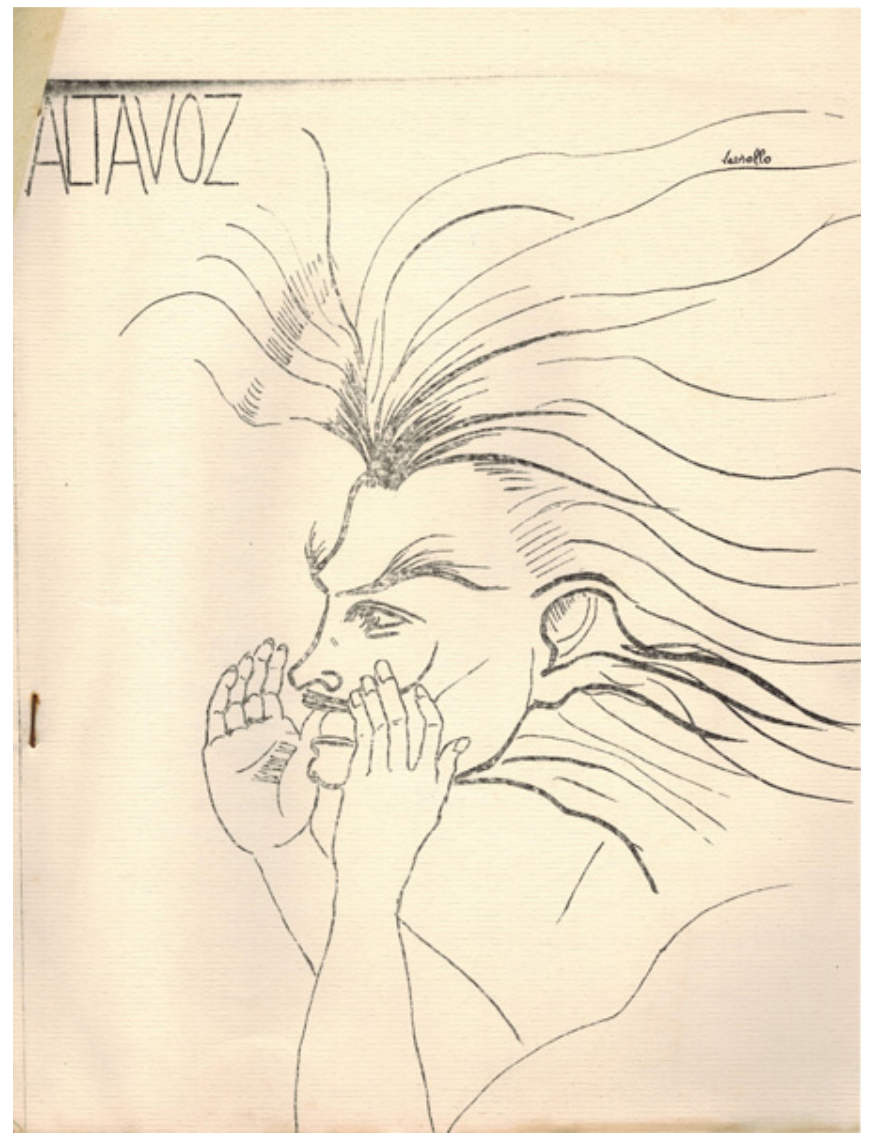

Portada del primer número de la revista Altavoz. Literatura y expresión española, publicada por la Universidad de Argel, 1971-72 


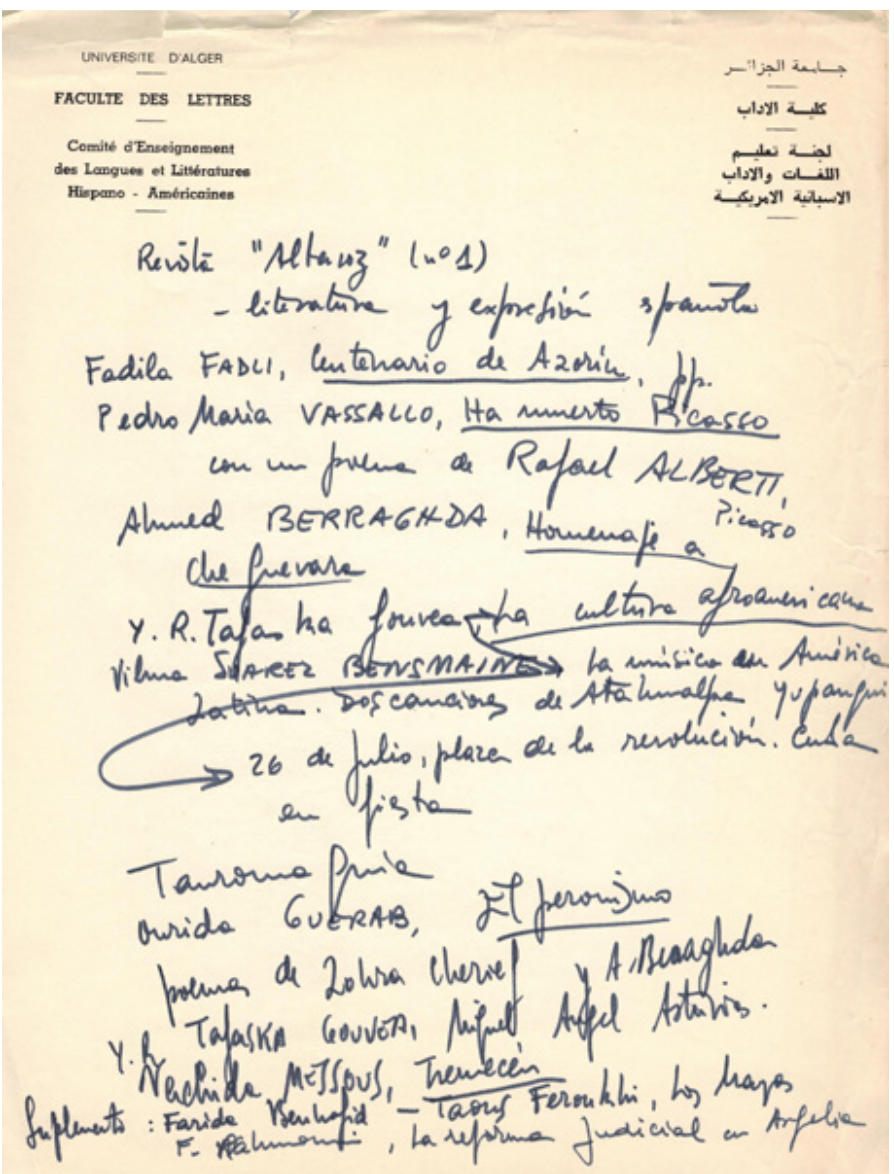

Texto manuscrito de Míkel de Epalza relacionando los contenidos del primer número de la revista Altavoz, conservado junto al ejemplar que se encuentra en el Seminario de Estudios Árabes e Islámicos de la Universidad de Alicante 



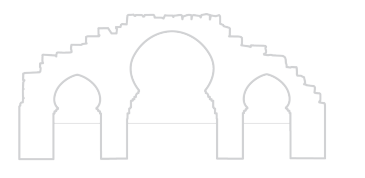

Biblioteca 



\section{ABDALLAH HAMmadi}

\section{CONVERSO CON EL OLVIDO \\ (Poemas)}

Edición de

Isaac Donoso

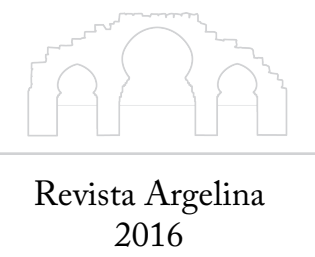



Converso con El Olvido

¡El temporal de la soledad muerde el vacío de tu horizonte! $\mathrm{Y}$ una frescura de arco iris cae en pesadillas en tu lecho nocturno.

¡Lejos de viento quedó tu arenal sin navío.

¡Qué sorbo de aroma te alivia!

¿Qué grito fantasmal se ve urgir entre las ventanas de tu abismo! Lueña se marchó, aquella brisa de tu mañana.

Amo con la fuerza del azor el azul celestial que se derrama de las lenguas de tu alborada.

¡Oh sonrisa, fúnebre y polvorienta, no te acerques a su dolor con tu placer de cuchillo!

\section{II}

El viento del sur lamenta esta noche.

Le vi arrascar el opaco mirador de un corazón perdido.

Suele esparcir frescor de recuerdos: 
suele acariciar labios sedientos

de tu ventana:

suele vender con ternura aquella frente.

El viento de esta noche

con pesadilla de cristal se rompe

en tu pecho.

\section{III}

Late corazón... No todo

se lo ha tragado la tierra.

A. Machado

Un olor de malestar cubre la cal de mi estancia, y un hálito de suspiros verdes marcados por fenazos de estupor desvelado, tendido al borde de una almohada. Una silueta fugaz con hullas grises se quedó tejida en un pensamiento. Ya ves la noche, amarrada en su atarazana con las estrellas del recuerdo.

¡No gira el espacio esta noche, se ve contoneando, vacilando y vuelve a recaer en tu regazo como pesadillas desérticas! Todo huele a fervor de dunas. ¿No sé qué? ¡Tal vez a senderos torcidos con cristales de espejismos rotos en una garganta sediente!

Dejé la frente al alcance de la brisa del atardecer...

Dejé los brazos hundir en los rayos teñidos del ser y del estar... 
Nada trajo al pájaro dorado de aquella isla de miradas solitarias.

Sigue mordiendo el capricho una vaga visión brumosa desatada.

Tal vez, clara como un sorbo de un ojo de azor, sigue entretejida entre las uñas de un expatriada casida.

\section{IV}

...Me acerqué a su mirada

con el fin de recolectar

los narcisos de su pecho.

Cuerpo a cuerpo se lanzaron

disturbios en los labios,

y de golpe se vertió

un vaso lamiendo el suelo.

¡En el acto vi naufragar los narcisos

en la clara oscuridad!

\section{V}

\section{FEDERICO}

VOCES TE RECLAMAN DESDE LAS ALTURAS DEL ATLAS

Aquí me tienes ante estos ojos tuyos que hicieron crecer a la morena aceituna. Aquí estoy, empapado con sangre de la revolución y polvoriento de las arenas del lejano Sur. He sido enviado, sin más presentes 
que una flor lírica de palpitar beduino, una cabalgadura beréber

para la que todas las distancias son estrechas, y una azucena árabe de pétalos marchitos.

Ay hermano, ay hijo de mi madre, que nuestra sangre tiene ya sus frutas maduras en las alturas de ese Atlas que se extiende bajo este horizonte, que las balas de la O.A.S. no son ya más que una extraña melodía que suena en nuestros trigales verdes. Esos mártires nuestros que cayeron en los barrancos se han convertido en una fragancia silvestre que llena de júbilo los astros del cielo. Hermano, tu que eres hijo de esa madre nuestra que es una lírica beduina.

He venido de los picos del Aures, enviado con la carga de ese pueblo que ha sembrado en cada surco un grano de revolución.

¡Ay hermano Federico!

Que he venido para sacudir de tu frente el polvo del olvido para sembrar sobre tu losa una flor cuyo nombre es al-Andalus. Hermano, que hoy vengo para llevarme la ceniza de tus huesos y quemarla como incienso en el templo de nuestra liberación sagrada.

Voy a llevarte a mi pueblo, hermano, 
a ese pueblo que ha hecho nacer el sol en medio de la oscuridad nocturna. Voy a llevarte a mi tierra, ésta que supo enseñar al enemigo el modo de inclinarse

ante los brazos robustos del pobre.

Voy a llevarte, en fin, hacia la lejanía, bajo aquella palmera orgullosa, junto a aquel pozo de agua de cristal Y sobre la alfombra dorada del desierto, voy a edificar el templo de tu culto, que será construido con los laureles de la poesía beduina.

Levántate pues, hermano, y mira hacia el Sur que flota en espejismos.

Verás allí una silueta que destaca entre las dunas del hogar.

Es la imagen de alguien que espera anhelante, vamos, ven conmigo, para que nuestra tierra de libertad celebre tu llegada.

\section{VI}

\section{A MACHADO}

¿Hiere tu corazón la luz de la luna ensangrentando la noche tus párpados en vela?

¿Te sumerges en el aire como la niñez perdida a jirones en las haces 
del gentío?

¿Gritas buscando dónde está Dios, siendo tú Dios amado del hombre?

¿Soplas, soplas como la tormenta?

¿Hierves, hierves como el ojo de la bruma?

$¿ A b r e s$ al viento tus ventanas

mirando a la aurora

de mañana:

y en una barca de fantasía infantil

abandonas las esperanzas, soñolientas

como la victoria?

¿Anhelas la plaza vacía?

¿Y la fronda verde floreciente

y el sol en el crepúsculo rojo

y la luz que se entierra

pese al destino?

¿Por qué, hijo del sol meridional,

hiciste de la vida una nota

de guitarra?

\section{VII}

Tu imagen detrás de un cristal de despedida

me persigue,

hasta alcanzar el fondo del mismísimo

sentimiento.

Era tenue, borrosa, lejana

pero en el fondo del espejo se declina

como un planear de una gaviota

sin marinero. 
Sigue, y me persigue palpitando

con un adiós sin promesas

$\mathrm{y}$ sin silencio.

Arde corazón, gime suspiro

la tarde lluviosa y el cantar

a tu alcance.

Lejano quedó tu cristal:

oh mundo de aquella tarde.

Todo se fue tras un cristal

alejándose con el recuerdo de una mano

y con la despedida en la otra...

¿Adónde va tu camino caminante?

Una silueta fugaz te la robó

una vaga tarde de llovizna

casi de invierno

mientras una espina de pasión

se clava en el ocaso...

\section{VIII}

A mi amigo Juan de Loxa

La tormenta de ayer me parece

una flor lejana que se escapó

del exilio de aquella primavera

¿Recuerdas...?

¡Ya sentí que sólo fueron palabras

reflejando conceptos torturados

con fulgor de una oscuridad

verídica por encima del espacio!

Son palabras que nos relatan palabras

rojizas como espumas o plumajes 
regados por las últimas gotas

de un polvo del mediodía.

Palabras quemadas de un sol infernal

que de tanta transparencia se ven oscuras

por herencia.

Como una mesa cargada: pero no sé

de qué puede ser cargada... tal vez

de pánico.

La palabra se siente famélica, por eso

muerde el espacio.

El espacio se esconde tras un cielo de claridad

y se refleja al borde de una carretera

de rayos...

Oscura, clara transcurrió la palabra

ahorcada antes de nacer frente

del espacio.

Qué claridad nocturna se ve fundir

con ojos lánguidos, cristalinos, tenebrosos

y aromáticos.

Al borde de la rivera una clara

palabra atada al tronco del espacio.

\section{IX}

Ve y despierta al copero que parece dormido: ya el relámpago al ámbar oloroso ha encendido. Ven, escánciame y bebe este fragante vino, No bay delicia en el mundo como su cara hermosa y la copa!

lbn Játima de Almería, s. XIV

Pensé que sigues esperando 
tras el velo con tus ojos de hurí

la llegada del Halcón de Qurays.

Ya es tarde, muchacha

Katy ha denunciado tu velo.

Sal de tus follajes con tu vaquero

de gringo.

¡El Zoco del viernes dejó

de hervir desde el año del "catapún"...!

¡La túnica de tu amante

en una jaula cristalina

respira un aroma de peste

de un dólar californiano!

\section{X}

Galopando, sobre una montura

de un espacio sin vestido

sobre una crin fugaz de un

viento llamado caballo.

Nada impide el paso

una palmera altiva mirando

al cielo sin hacerme caso.

Un buen jorobado

entretenido con el ocaso.

Todo como lo ves gira en torno

del espacio

nadie, con su hacha negra

impide las ceremonias míticas

del Siroco.

¡Así vuelvo a nacer cada día

con mi montura y mi viento! 


\section{XI}

Tengo frío mujer de mis

quimeras,

tengo sed, ninfa del

norte...

¡Ya, me encuentro vacío

sólo, con mi recuerdo

y mi desierto!

Además, la madre virgen

de la "Lírica" espesura cerró

sus puertas a mi pecho.

¡Qué lástima!

...aún pido un trago

de suerte...

Abre hacia el calor tu ventana;

traigo del lejano arenal

una flor de canto.

\section{XII}

\section{¿No VOLVERÁ NeRUDA?}

No volverá. No.

No volverán a escribirse los versos más tristes ni de nuevo titilarán los astros en la Onda azul infinita.

No volverá...

$\mathrm{Ni}$ girarán los vientos desnudos en la noche para abofetear las contraventanas cerradas.

No volverá. 
Y ya no se pedirá el castigo de las serpientes y de las hienas voraces.

No volverá...

y no se verá la noche inmensa sin la amada.

No volverá

para cubrirla, como la primavera

cubre a los cerezos.

Y no caerán los versos, como el rocío sobre el pasto,

encima del corazón huérfano

bajo las tinieblas de penumbra.

¿Quién infundirá paciencia

a la tierra y a los indios?

$¡ A$ Ah, montes de Chile, alturas de Macchu Picchu, ardientes hombros de $\mathrm{Cuba}$ encendidos hornos del cobre, remotos pueblos de España como luciérnagas en la noche oscura!

¿Quién levantará la melodía del verso, alimento eterno, hacia los corazones que laten en el bramido de ola roja arrasadora?

No volverá...; y no morirá...

Y no veremos el amor que sopla de los labios de Peleas y Melisenda.

No volverá el pan de los pobres ni se trillará la vida bajo los cascos de los caballos. 
¿Marchaste porque te llamara Lorca

desde los rayos del alba?

Cabalgaste en el hoyo del último sueño

besando a la muerte?

La piedra de la muerte no ensangrentará tus

pasos

infinitos.

He sabido del rayo de luz

que el relámpago de la letra resplandece

hasta el fin del mundo;

y he sabido del eco del crepusculario que una

estrella

en el sur dibujó el aliento

de tus entrañas angustiadas.

Y saltaste sobre el mar de la muerte

Y caíste en el cielo de la vida.

Cante tu dulce voz,

plenitud de todas las gargantas humanas:

duerma la gloria de vísceras degolladas

y huya el llanto

de la cárcel

de los ojos

carmesí

para siempre, para siempre

a los susurros,

a la noche que marchita los restos

de la vida. 


\section{XIII}

POEMA A MI MADRE

Palabra que no olvidaré, profunda como el mar con sabor de aire y gusto de amor en los labios.

La busqué en los collados de los códices antiguos, pero se escurre de mis manos como un pez de manos de un pescador.

Suave y lisa

la veo cercana junto a mí, frente a mis ojos saltones.

Y casi la toco y la vierto en mi copa

para beberla.

Y vuela con alas de pájaros gris

remontándose a lo alto

hasta desaparecer.

Resbaladiza, o di -si quieres-

bruma transparente

que se amontonó sobre mi pecho.

Habita en mi alma antigua y en la nueva, fluye en mis venas como la sangre (roja y blanca)

$\mathrm{y}$ ¿cómo no puede saber su contenido?

$\mathrm{Ah}$, dueño de la antorcha, con ella encendiste la luz violeta del sol. 


\section{XIV \\ Silencio HONDO DE GRANADA}

\section{A mi amigo Manuel Villar Gil}

El horizonte pálido se extiende

con su triste color

y sobre la alfombra verde galopa

el carro del tiempo

llevando los ídolos y las estatuas

y dejando tras si profundos carriles

sobre los grises rastrojos.

La ciudad blanca se alza con su pico erguido

y la colina roja despunta en un sol

que no conoce el ocaso,

en el abismo del océano.

Tiene días de mañana,

ignora las noches.

El tañido de la campana revuelve los

corazones

sedientos refugiados en las imágenes

para que los acune la esperanza

asomada a la orilla del infinito.

Un ángel de mirada faraónica,

de alas abatidas, hundida la cabeza

y el corazón roto en la cruz sangrienta.

Es el que se hundió en el mar,

sin retorno...

Ojalá mi verso fuera un sueño

frente a las preguntas del pasado, 
porque atónito no sé

si soy el amante o el extraño

en estos palacios.

Dolor de Granada dormida

¿Dónde está el bello perfume de la 'abayya

que arrastra su cola

y el turbante de puntas retorcidas

y la corona cristalina y brillante como el sol

en el degüel o del crepúsculo rosáceo?

¿Dónde están los potros, las cantoras, la corte?

¿Dónde están los Banu al-Ahmar?

Ay, pena de la partida antes de que llegase el extraño.

Pena de los palacios vacíos en los que se cerraron

hasta los párpados,

y la rosa que vigila sonriente

y el fragante jazmín y el narciso de pétalos abiertos

y marchito por la lejanía

en la estrechez del largo camino, dormido al amblar de los pasos.

Granada, aquí estoy abriendo mis brazos

ante tu gloria coronada de espinas

y, descalzo, piso tu esplendor

y me agota la humillación de épocas ya idas.

¿Dónde están tus tempestades y tus truenos?

¿Dónde está la inspiración bajada al universo?

¿Dónde las deliciosas fragancias

impregnadas del verdecer de los olivos

y del servo del Guadalquivir

que decapita con su daga

tu andaluza tierra dormida?

Ay, brisa ahogada con llanto de penas y 
dolores.

Partamos la desgracia y el pesar

bajo el cielo a quien encadenaron los años de miseria.

Aquí estoy, acurrucado, atormentado por el verbo

y el agente y la circunstancia y el adverbio

y la oposición a la luz de la luna

de equilibrio endeble.

¿Dónde está el relámpago, el chaparrón,

el león rugiente?

Quiebren las tormentas el vaso de mis penas

$\mathrm{y}$ agote los horizontes del sabor

de mi nostalgia.

Heme aquí, vivo sobre las trizas de la noche, expectante con su lámpara artificial.

Y tú, cantas en el Generalife, quejosa del sufrimiento lejano, tú que nadas en el alba del reino de la fantasía.

Despacio, cuenta la historia de la Alhambra, una canción.

Y si to corta la timidez, no to avergüences, porque en el silencio son dulces los susurros.

Aquí, envuelto en las ramas de los arboles, me atrapa el canto del agua con el murmullo de sus quejas.

Aquí estoy besando la frente del león de lomo hundido por el destino silente. Aquí, residuo de la bruma, espiral en el seno de Orión, errante, perdido. 
marinero sin nave, poeta al que el amor destrozó

los párpados sobre la guitarra.

No me preguntes cuando nos encontramos

tras el olvido.

Somas así:

vivimos y nos moriremos

pese a las campanas de la muerte.

Y quedaremos bajo el ala de la noche,

en sus tristes fulgores.

Enviamos el suspiro para verlo

como una lágrima que corre

en las mejillas del Darro.

\section{$\mathrm{XV}$ \\ A mi amigo Carmelo Sánchez Moros}

Cuando el agua susurra al oído de los guijarros, el céfiro se detiene cauteloso como espia;

pero un pájaro con su canto le delata, y el céfiro se atemoriza ante el escándalo.

Llora entonces una bruma procurando la sonrisa de las flores.

(Poeta granadino anónimo del siglo XV)

Por tu rostro sombrío

borraré las raíces del espacio.

Por tu agua gemida

me casaré con tu fragancia.

Por tus versos oriundos

sembraré mis arenas. 
Por tu muda sonrisa cabalgaré el viento

Por tu mirada marchita besaré mi alfanje.

Por tu trágica sin venganza

renuciaré a mi Sinhaya.

Por tus rosas del recuerdo

encarnaré a Abu-1-Hayyay.

Por tu sorda lejanía

resucitaré a Ibn al-Jatib.

Por tus torres brumosas

edificare mis casidas.

Con azucenas y zureo levantaré tu al-mibrab.

Con mi sudor de zinati

y mi yegua berberisca

alcanzaré tu Ben Omaya.

Regaré tus arriates, tu ámbar de Oriente

con el treno de mi laúd de mirto.

Por el vino y el copero.

Por el mancebo y la Zumaya.

Por Badis y el Bermejo.

Te haré ofrenda, mi Constantina.

\section{XVI}

Don QuIJOTE SE PONE EN CAMINO

Dedicado al gran poeta Vicente Aleixandre

¡Venga mi Rocinante!

el que suele rodar como un guijarro.

¡Venga mi rodela, mi espada y esa mi lanza 
tallada en colmillos de tigre de feroces junglas!

\section{iA mí!}

Pues que saldré a caminar, a derribar el molino ruidoso y arrancaré de raíz esos vientos que en mis oídos aúllan, que perturban el descanso de mi cementerio blanco,

la siesta bajo la frondosidad desnuda, el beso del azahar en mi marchita primavera, la siega de espigas en mis bancales yermos, el pasto de inútiles rastrojos, la noche, el día y esa llama de sol de helada crueldad.

¡Venid a mí!

y surcaré esa Castilla estéril que tal vez parirá un hijo con ala de pájaro, encendiendo, quizá, las velas de tu templo mortecino.

¡Venid a mí!

y abriré con la punta de mi lanza las venas de esta Mancha que perdió su último esposo.

¿No veis, acaso, cómo el luto marchita sus párpados?

¡Sancho, mi apoyo, mi compañero!

tú que eres parte de mí mismo, tú, mi propio camino, observa con atención y planea con oído lentamente:

Yo soy una bandada de pájaros

y con bandera blanca surco los campos. Soy una lanza de golpe fatal, 
cuya agilidad somete a las fieras.

Soy un buen nacido

que en la palestra te conquista la esperanza, Soy aquél que te ha contado las leyendas de Grecia

y quien pervivirá como las inscripciones en las ruinas antiguas.

Soy yo ese profeta enmascarado de selva, engendrado de la carne de la tierra.

Yo soy quien se arroja al mar

y te protege del furor de la tormenta.

Un bálsamo soy para la herida del pájaro, alguien a cuyo cuello se anuda la desgracia

y cuya ausencia es patente, cuando la tiniebla es rival de la verdad.

Con una luz rojiza voy en pos de un imposible preguntando a los hambrientos por el veneno de las sierpes.

Soy, en fin, esta miseria negra ansiosa de que salten los grilletes.

Ésta es mi rodela, Rocinante es mi caballo,

no es preciso que usurpe la yegua del testarudo $\mathrm{Cid}$

cuya mellada espada, es ya de inútil de tajo, y su Babieca rendido

¿No lo ves?

Está como un halcón acurrucado allá en Vivar y no consiente responder a mi reto.

¡Sancho, mi estandarte!

¡Sancho, mis sandalias!

Dejemos ya el descanso en estos aquilones.

$¿$ No ves, la brisa se entorpece con las alas del 
hambre?,

¿qué tiembla entre las uñas del águila?

Las moscas crueles, coma un reloj en las senos del tiempo van contando sus vertebras. ¡A mí, Sancho! ¡A mí, compañero!

Disponte ya, pues que hoy serás mi escudo, mi arnés, mi ejército.

Serás hay mi polvo y mi bonanza y mi nube

y esos labios míos conscientes bajo la luz de la luna.

Caminaremos con el viento dejando los ritos

bajo los cascos de nuestra gloria, devolviendo así a la noche su peregrino sol,

y libertad al mar que preso está de península,

que las cadenas le sangran y se desangra, que la pasión le atormenta y es tedio su esperanza.

¡Vamos, vamos!

Abandona tu cantina,

lanza al viento tu rebuzno

y en la tierra engarza tu perfume.

¡Vamos ya!

Mira al Norte y observa cómo nos acecha como un halcón en su atalaya;

óseos restos en sus garras manchadas de sangre, despojos de tan palpitantes entrañas que reclaman el quejido.

También leves plumas que bajo el ritmo implacable de su picotazo aprendieron una nueva canción. ¡Vamos!

pues los carros de ayer pasaron, no conocen el regreso. 
Los ídolos de viejas glorias que arrastrara el Tajo,

enterrados yacen en el Guadalquivir.

El grito lejano de un niño se derrama en

la plenitud del camino

y es un grito de socorro.

¡Y paloma blanca!

¡Y cueva de hambrientos!

que tu susurro resuene en la cosecha de mi

llanto,

las lágrimas laven los céfiros de mi angustia, cave una tumba para la cobardía

y entiérrala en las nubes.

Arranca el arado del tenaz espejismo

y cabalga a lomos del cielo.

Saluda, en fin, a la embrionaria mañana

pues que a ti ha venido el más valiente

blandiendo la espada del rescate.

¡Ay Sancho, mi camino!

¡Sancho, mi esperanza!

mira no te encadene la ilusión

no vayas a olvidarme.

Arrea tu jumento,

suelta al viento tu barba hirsuta,

déjala que abrace el horizonte,

que viaje a esas estrellas que murieron lejanos

techos.

Déjala revolotear como a la gaviota que picotea

conchas en el arenal de una playa.

Y que a las tumbas lleve su mensaje.

$Y$ que encienda un pabilo a las tinieblas.

Que lloriquee como el recién nacido,

pues que el llanto mostrará el camino hacia el 
seno cariñoso.

Déjala que nade en el espacio, competir con la melena del león que corre tras la presa.

Que suelta sea su brida hasta que estalle como el ritmo del timbal.

Tal vez avise los oídos de esos cuervos que duermen en lodo de pútrida carroña.

Deja que allane mi camino

y escánciame en tu vaso de barro

licor de fuego y sangre.

Que los sorbos que me ofrezca derritan el hielo en mi garganta.

Permíteme cortar una rosa de tu lanza, acaso fructifique en mis entrañas

el puñal envenenado que raspa mi sueño.

Arre tu jumento, camino mío,

abre las puertas a una difícil jornada,

deja que el rebuzno llueva sobre mi cuerpo desnudo,

competir con el viento y con los días perdidos, ser como un golpe sagrado que asestara al fuego.

¡Sancho, Sancho!

crucemos ahora el mar

y que tu ágil lengua se deslice como una balsa

y tu sonrisa de tierra como una vela se ice.

¡Adelante!

toca el mar con tu vara mágica, que yo, mi espada y mi escudo, Rocinante y yo prenderemos las espigas del viento 
y entonaremos para ti el himno de la tierra:

Así vamos, amigo mío, compañero, lamiendo la infinita planicie del mar que hierve, se algazara y se rebela.

Cual si destello de alba se tratase,

o un cementerio antiguo

o una ciudad bañada en sangre, cuyo pendón blasonase a una paloma.

Don Quijote soy, el profeta embozado, tal vez, esa tortuga que por burlar los colmillos del tigre, destuvo un instante la luz de la jungla.

Don Quijote, sí, amigo mío, que cabalgó su locura para ofrecerte el sueño de una casida.

Madrid, 20-6-1975

XVII

¿POEMA AL BURRO?

A mi amigo José María Forneas

Camina, burro,

y no te excuses.

Sé que la carga

ensangrentó tu lomo.

Lo sé.

No te menosprecies 
porque tras de ti

cargo yo la mía.

La soporto desde que la noche

se entrevera de luz,

caminando, caminando, caminando...

En las tinieblas, en el barro

¡repicando tambores

y fabricando flautas

y vainas de espada

para las fiestas!

Heme aquí corriendo sobre tus huellas, que no dejan más rastro

que el infinito camino.

$Y$ cuando volvemos la vista

se nos convierte en fantasma;

Y si lo montamos

es una cabalgada en un palo

de niño.

Lo piso

y no volveré a montarlo.

Me voy, como ves, me voy

hacia la orilla roja

donde bebo - contigo-

el llanto de los peces

y como la espuma del mar

hasta que torne la luna

de su largo viaje.

Dormiremos abrazándonos el cinturón

de la playa

y besaremos la arena.

Leeremos, a la madrugada,

palabras de sonámbulo:

un ojo 
derramando llanto

con letras silentes

dormidas sobre la seda larga

que invade el silencio.

En la enfermedad de su pobre tierra

como las hojas del otoño.

Camina, pues, burro, que la aurora asciende y deja el camino a quien lo compra...

¡Chiss, camina y calla!

\section{XVIII}

Dueño del ocaso carmesí

flotante sobre las ondas, dame tu halcón

préstame luz de tu imaginación alada

para verla y palpar su latido

y déjame surcar los campos en la tiniebla

estúpida, con los brazos abiertos

y la cabeza al aire,

llevando en mi mano tu ascua

que quizá encuentre en las torrenteras

o en las colinas eternas,

o paciendo en jugosos pastos silvestres.

Y si cantan los pájaros su sentir

percibo en el vibrar de sus trinos

un eco ascendente

hasta abrazar las nubes.

Y la veo.

Un alma sin cuerpo que traza en letras de 
plomo

en pos suyo la palabra nostalgia diciendo:

Estoy aquí, ven conmigo, si quieres...

$\mathrm{Y}$ viajo en la barca de mi fantasía

despertándome el runrún que arrulla las pobres

hojitas del otoño

y punteando en su laúd:

"Nostalgia, ¿cuándo nos uniremos, cuándo se fundirán las almas?”.

Y otra vez, y tantas veces, como siempre

la veo escrita con letras viejas

sobre la frente de quien despide,

de amanecida, al marinero

y anhelando abrazarle con el crepúsculo.

$Y$ cuando regresan, ves en sus pasos

dos palabras que saltan alborozadas

estrechándose. Eran:

"amor y nostalgia que se reencuentran

tras el abandono".

\section{XIX}

A mi amigo Rafael Rodríguez

...Compañero, amigo, aji

camarada de mi llanto;

suelta tu ardiente fulgor

sobre mi espada.

Alza tu puño feroz

Sobre mi palabra

y clama al cielo fugaz... 
...¡Qué maravilla!

Pórtate firme, bravo y muro

surca las dunas del mar sin agonía...

Ahí, verás, allí tendrás

un corazón de melodía

allí, gime un dolor que

hierve en fantasía.

...Camina burro

solo, con el sudor

en compañía.

\section{XX}

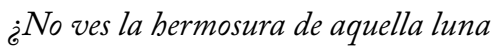

en el horizonte?

Parece una corona, tal vez arco iris, una barca, a una letra de Nun escrita con lima de oro sobre un cristal azul

Abu-1-Baqà de Ronda, s. XIV.

Siempre navegando por el camino:

desde los confines del Hoggar, un vasto

pasto

de arenal me guía;

¡lamiendo el céfiro de un latido sereno!

Un río de cristal se vierte

hacia el infinito

En la otra orilla, dos siluetas de verde

clamor suplican el horizonte.

¡Qué claro deleite se ve vagar

persiguiendo la sombra de una caravana 
de zureo y velos de un atardecer herido!

Te llevo como a los suspiros intercostales, te llevo pese a las mareas de verde oleaje.

Ya no siento vacío

ni con cristal roto en la frente;

sólo gacelas de nocturnas miradas

$\mathrm{y}$ de panal de sonrisas.

Deja fundir tu sombra en el asfalto

del descubrimiento...

En las vidrieras congeladas, de un Museo

sombrío

iitus huesos de ayer se besan con faroles!! 
Glosario:

'Abayya: Túnica árabe

Abu-1-Hayyay: Yusuf I, rey de Granada (1333-1354).

Aures: Montañas en el noreste de Argelia donde se declaró la revolución de 1954.

\section{Aji: Hermano}

Banu al-Ahmar: Dinastía de los reyes nazaríes de Granada $(1232-1492)$

Casida: Poema monorrimo árabe

Constantina: Ciudad en el noreste de Argelia.

Halcón de Qurays: Calificativo con el que se conocía a Abderramán $\mathrm{I}$.

Hoggar: Región de los hombres azules llamados Tuareg.

Ibn al-Jatib: Gran visir de Granada y poeta (1313-1375).

Sinhaya: Tribu beréber.

Zinatí: Apellido beréber, de donde viene “jinete”. 


\title{
EL CONSERVADURISMO EN LA POESÍA ÁRABE
}

\author{
ABDALLAH HAMMADI
}

El insigne maestro D. Emilio García Gómez, según mi criterio es un creador insuperable de temas de debate (o, mejor dicho, de temas dignos de ser abordados con rigor y firmeza...). Hojeando su estudio acerca de Ibn Zamrak se ve que su criterio acerca de esta época carece de elementos que justifiquen su visión global y gracias a su genuina intuición acierta en la mayor parte, como en el caso de este párrafo suyo, en el que dice: "Mientras las letras occidentales padecen con frecuente periodicidad terremotos estéticos que alteran por completo su fisonomía, la poesía árabe, desde el Islam, sufre apenas leves sacudidas sísmicas, ligeros desplazamientos espirituales que no llegan a quebrar el armazón de una técnica intangible. Mucha mayor libertad tuvo en tiempos anteislámicos para el desarrollo de particularidades indivisibles..."1.

Mi deseo es encontrar la respuesta a este planteamiento por parte del gran profesor, pero no ha sido más que plantear una serie de preguntas sin respuestas. Quizás esta respuesta, a mi modo de ver, pudiera deberse a muchos elementos coherentes entre sí y opuestos, pues hasta la mismísima época a la que atribuye García Gómez ciertas creaciones a nivel individual, se caracteriza por el fenómeno que predomina en el panorama conservador de toda la poesía árabe, de tal modo que no se puede decir que la aparición del Islam marcara un hito comprometido ni tampoco existió esa relativa libertad que permitió destacar individualidades.

${ }^{1}$ Emilio García Gómez, Ibn Zamrak. El poeta de la Alhambra, Granada, Patronato de la Alhambra, 1975 p. 76. 
La poesía ŷabilī se caracteriza por su autenticidad, su identidad propia y no por sus individualidades creativas, porque en su lírica trascendental cayó en tópicos que sólo basta citar (al-At-

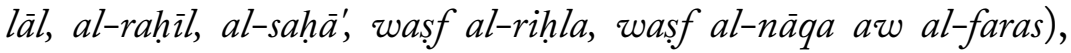
luego lo que se llama al-Istitrād, que es dejar el tema principal y describir temas que luego los críticos con derroche de esfuerzo intelectual intentan demostrar que existe una cierta unidad entre el tema principal y el al-Istitrād, y es una "unidad artística" (wihda fanniyya) aunque esto a mi modo de ver es pura elucubración. El poeta ŷabilī sentía en su fisonomía el elemento de la libertad y eso se debe a su contorno ambiental, pero por otro lado se encontraba ligado a una gran familia que es su tribu, donde la 'așabiyya (lazos de sangre), según Ibn Jaldún era el elemento fundamental; entonces, sin llegar más allá, cayó en el tópico, y son de sobra conocida las quejas de Imri'-1-Qays, Zuhayr y 'Antara ${ }^{2}$ por lo estrecho que se encontraba el campo artístico de la poesía.

Algunos enfocan el asunto desde otro punto de vista y creen que al Islam se debe la pérdida de varios géneros que debieron existir en la Ŷabiliyya. ¿Cómo nos ha podido llegar el género llamado saŷ $a l-k u b h a ̄ n$, prosa rimada de los paganos, por su dificultad de transmisión, comparándola con la poesía que es algo fácil para la memoria?

Puedo deducir de todo esto que el poeta no tenía más remedio que seguir las corrientes de su tiempo, reflejadas en los moldes concretos que se imponen por parte del ambiente artístico, o quedar marginado. Así se representan los moldes perfecto de la poesía $\hat{y} a b i l i ̄$ en las múallaqāt, ejemplo supremo de la creación poética y modelo de cómo se debe componer el poema para impresionar y ganar la emoción del oyente. En definitiva, la época ŷabilī no estuvo libre del fenómeno "conservador" que

${ }^{2}$ Šawqī Dị̂, Al-fann wa wadābibu-hu fì-al-sìr, El Cairo, 1943, pp. 5-6. 
va a aumentar en el futuro y seguir vivo en la tradición poética árabe hasta nuestros días. Llegó el Islam y la acusación dirigida al Profeta fue que sus palabras eran poesía. Azora no 21 , aleya 5: "No — responden los infieles_ ¡son sueños turbios! ¡Él lo forjó! ¡Él es un poeta! ¡Tráenos una aleya similar a las que se mandaron a los primeros enviados!". Y tuvo que defenderse de los ataques y dar el criterio del Islam en lo que concierne a cómo debe ser un poeta, azora no 26 aleyas 2-28: "los que creen, hacen obras pías, invocan en frecuencia a Dios”.

Pese a la postura del Islam respecto a la poesía y los poetas, el Profeta no tuvo más remedio que utilizar esta arma y luchar contra sus enemigos. Sus poetas comprometidos son muy conocidos, basta recordar el nombre de Hasān b. Tāâbit, que entró en la historia de la poesía con el apodo de "poeta del Profeta" y otros como Ka'b b. Zuhayr, etc. La poesía en la época islámica, y me refiero a la heredada de los $\hat{y} a \bar{b}$ ilīes, ha servido como manantial para los poetas, tanto para adquirir riqueza léxica, como conocimientos históricos y genealógicos que sirvieron para defender sus honradas raíces frente a una nueva invasión ideológica... Entonces para explicar o entender el Corán hay que conocer la poesía $\hat{y} \bar{a} h i l \bar{\imath}$, para buscar la perfección gramatical hay que ver cómo pronunciaban los ŷāhilīes, para componer buenas alabanzas hay que acudir a Zuhayr o a al-Nābiga... También la sátiras resucitaron con las nuevas generaciones islamizadas y arabizadas, porque ahí yace la perfección léxica: estos moldes arraigan en las gentes y emigran con ellas a los nuevos territorios conquistados por los nietos de los ŷähilīes como parte sentimental y patrimonio heredados de antaño. Con este espíritu conservador se enfrentaron a las nuevas sociedades y los cimientos de la poesía arcaica se mantuvieron firmes, burlándose de las quejas de Abū Nuwās, de Baššār, los intentos de Abū Tammām (véase al-Muwāzana). La emigración hacia nuevos territorios y sociedades sirvió como elemento fundamental para la 
conservación del pasado heredado, los anhelos de 'Abd al-Rạ̣mān I dialogando con la palmera son prueba de la añoranza de un pasado lejano que caracteriza al periodo omeya y aquel que vive en Damasco dirige su pensamiento hacia el Naŷd o Tihāma.

Por eso al abordar este tema, tanto Blanchére como García Gómez no dieron importancia a este fenómeno, que más o menos ha tocado el insigne Vicente Cantarino en su estudio re-

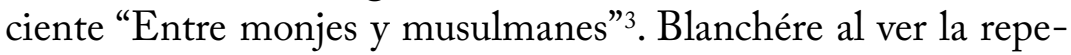
tición continua que caracteriza a la poesía árabe en lo tocante a metáforas y lenguaje, lo calificó como "negligencia o falta de esfuerzo del poeta", y ese criterio lo dedujo hablando de Ibn $\mathrm{Za}-$ mrak, García Gómez veía en la repetición de ciertos topónimos una idea arraigada en el subconsciente. Todo esto, a mi modo de ver, se debe a lo que hemos citado y a algo más: el poeta árabe por su rápida emigración, se encontró lejos de su tierra y llevó su pasado como recuerdo o sueño vago y cada vez que encuentra este pasado representado en un poema, una historia o un nombre de lugar, se aferra a él desesperadamente. A esto alude Ibn Bassām (m. 1149) en su Dajīra, de quejarse de la gente andalusí: "Los de este país que escribieron literatura no se propusieron otra cosa que seguir e imitar a los escritores de Oriente... de tal modo que, si en aquellas regiones grazna un cuervo o en la más lejana comarca de Siria o Iraq zumba una mosca, doblan su rodilla ante esto, cual si fuera ídolo y leen estas cosas como si se tratase de un libro notable". Los gritos de Ibn Bassām fueron en vano, tal como los de Ibn Hānī al que molestaba el aprecio de la gente de su tierra andalusí por alMutanabbī, estando él a la misma altura. Todas estas quejas fueron sin eco y lo mismo se decía en Oriente, tanto en la época omeya como en la 'abbasí, contra las continuas alusiones al de-

${ }^{3}$ Vicente Cantarino, Entre monjes y musulmanes: El conflicto que fue España, Madrid, Alhambra, 1978, pp. 18-76. 
sierto de Naŷd y a la península arábiga y su historia preislámica. Es un clamor de exiliado, son anhelos de expatriado que no pudieron borrar ni el espacio ni el tiempo. A este elemento se debe el fenómeno conservador y la carencia de terremotos estéticos. Otras circunstancias también lo respaldaron; al pensar los árabes en glorificar su lengua y componer reglas gramaticales, no tuvieron más remedio que volver otra vez al desierto y tener como fuente de inspiración a los beduinos de pura cepa. Lo mismo ocurrió con el Corán para comentarlo y explicar sus palabras, sin olvidar que todavía no existía la escritura y los hijos de los beduinos junto a las espadas y debajo de las corazas llevaban la única herencia cultural que poseían, esto es, las casidas para ufanarse ante las civilizaciones persa y bizantina. Esto es lo que llevaban junto a la nueva ideología espiritual; gracias a lo cual nació la transmisión oral (الرواية) , fenómeno que vino como vínculo para forzar el espíritu conservador y exigía una cadena que permitiese vivir la tradición continuamente sin darse uno cuenta. A consecuencia de eso al-Intihăl (el plagio) ${ }^{5}$; muchos trasmisores por fuerza de la influencia, compusieron en varias ocasiones con el mismo estilo y espíritu obras que atribuyeron a poetas $\hat{y} \bar{a} h i l i \overline{e s}$, todo para obtener el prestigio de transmisor y conservador de la herencia. La crítica, tanto clásica, encabezada por Ibn Sallam al-Ŷumahī en su Tabaqāt como moderna, con

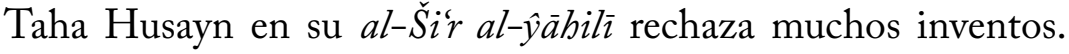
Baste con citar a Hamad 'Aŷrad y Jalaf al-Ahamr al que se atribuye la famosa lāmiyya (J) del poeta bandolero al-Šanfarà. Junto a este fenómeno nació la rigurosa crítica que exige según la línea tradicional y crea nuevas imágenes. Así tenemos otra ca-

${ }^{4} \mathrm{Ni}$ 'mat Rahīm al-'Azawī, Al-Naqd al-luqawī 'ind al-'arab hatt' nihāyat al-qarn al-sābi'al-bî̀rī, Bagdad, Wizarat al-I'lām, pp. 35-52.

5 Julio Samsó, "La cultura árabe preislámica", en Revista Histórica 16, 1979, año IV, núm. 38, pp. 73-74. 
dena de transmisiones de versos que nos indica, por ejemplo, que tal verso de al-Mutanabbī está inspirado en Abū Tammām, éste en Ŷarīr, éste en al-Nābiga, etc. Nació lo que se llama ( "التوليد / (recreación) y así quedó la poesía árabe en un círculo vicioso, sin salir de él y sin romperlo, por puro afán de permanecer en contacto con el lejano pasado, y surgió la nueva forma crítica que defiende el porqué los poetas caigan en el tópico o repitan imágenes y metáforas creadas por poetas anteriores. Lo mejor que se ha escrito hasta ahora acerca de esto desde mi punto de vista es la epístola de lbn Rašiq al-Qayrawānī titulada Qurādat al-dahab ${ }^{6}$ que compuso tras haber sido acusado de haber "robado" unas metáforas de dos versos del poeta al-Nahšalī y demostró en este magistral ensayo cómo pasan las imágenes poéticas de un poeta a otro.

Otro elemento fundamental para el fenómeno conservador y que evitó las tormentas estéticas fue la tradición del aprendizaje de memoria de miles de versos, que en primer lugar sirvió de transmisión de la cultura y en los tiempos anteriores, casi desde la época 'abbasí tomó otro concepto. Así vemos que Abū Nuwās, no sabiendo cómo llegar a ser buen poeta, fue aconsejado por su maestro Wāliba para que se retirara al desierto y se comunicara directamente con los beduinos, conservadores del más puro árabe, y aprendiera de memoria miles de versos. Abū Nuwās se regocijó con esta idea, la cumplió y, sin darse cuenta, regresó ya con los moldes que anteriormente hemos explicado, cargado de todo lo tradicional; como no le faltaba don para la poesía, expresó sus sentimientos según los moldes grabados en su mente y ya no se pudo librar del sonido de las rimas ni pudo traspasar las fronteras de los metros tradicionales, pese a sus in-

${ }^{6}$ Ibn Rašīq al-Qayrawānī, Qurādat al-ḍahab, El Cairo, Maktabat alJānŷī, 1926, pp. 10-59. 
tentos cuando consiguió su madurez creativa. Abū Nuwās, según mi criterio, es uno más que se añade al conocido círculo monótono, y así anduvieron todos los que buscaron la vía de la poesía, compitiendo en el aprendizaje de los miles de versos. Abū Tammām se enorgullece y se siente insuperable al mencionar que sabía de memoria 14.000 arŷuzza (poemas rimados por el exterior y el interior) tal como conocemos por su famosa antología titulada al-Hamasa, al igual que su discípulo al-Buhturī. Lo mismo se dice del genio de la poesía árabe, al-Mutanabbī, que antes de alcanzar la fama tuvo que pasar por la escuela beduina. Ibn Jaldún repite este fenómeno con claridad en sus prolegómenos (Muqaddima) aconsejando a los jóvenes aprender de memoria miles de versos para llegar a ser poetas y añade que la mente humana se expresará según el contenido que la llena, si se aprende buena poesía, se escribirá buena poesía y si se aprenden cosas malas, se expresará uno de manera correspondiente ${ }^{7}$, como dice el refrán: "cada recipiente rezuma de lo que tiene", aplicó la experiencia a él mismo y se asombró del enorme número de poesías que llegó a aprender, pero como él nació para otros menesteres no pudo tener éxito en la poesía, expresando sus sentimientos con poemas de bajo nivel estético ${ }^{8}$. Al poeta por tanto sólo le quedaba una salida, o bien recrear (ولد (و) las imágenes antiguas en nuevas creaciones o seguir en la línea que García Gómez definió a Ibn Zamrak: "su literatura es por lo general arcaizante, glosas de glosas, comentarios, erudición, reiteración en poesía y prosa de arte, de tópicos y clisés precedentes. Incluso en el terreno de la historia de las instituciones y de la doctrina política se han limitado demasiado a menudo, dice el prof. G. S. Colín, a recomponer los modelos clásicos que re-

${ }^{7}$ Ibn Jaldún, Muqaddima, edición de A. M. Katemir, Beirut, 1970, tomo III, pp. 336 y 346-351.

\section{${ }^{8}$ Ibidem.}


presentaban los diversos organismos del Estado como cabrían de ser teóricamente, en vez de describirlas tal como los veían

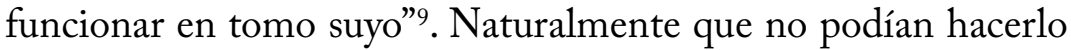
por el puro afán de traer a la línea conservadora nuevas fórmulas metafóricas que quizá den al poeta una cátedra junto a los inmortales. Para apoyar más nuestro criterio brindo estas palabras de García Gómez con las que estoy totalmente de acuerdo: "La obra de Ibn Zamrak - y este criterio se puede aplicar a cualquier poeta - es una especie de museo donde están expuestos y catalogados, aunque un poco empalidecidos, todos los temas de la lírica anterior; un vasto cementerio donde en tumbas perfectamente alineadas yacen todos los tópicos de la poesía arábigo-andaluza" ${ }^{10}$.

Todavía falta algo importante, aunque ya lo nombré anteriormente, con los fenómenos de la métrica y de la rima. Para conseguir ser maestro de estos moldes hay, antes de empezar a escribir poesía, que adquirir musicalidad y una rima sonora que necesita una riqueza léxica infinita. Para adquirir todo esto se acude a la memoria, por eso fueron famosos los grandes memoristas, por ejemplo en la Granada nazarí Ibn Ŷuzay al-Kalbī era temido por su vasto dominio memorístico de la poesía clásica, al igual que Ibn Jamīs de Tremecén y otros.

Se deduce de todo lo citado que el poeta se encuentra otra vez atado a lo tradicional: si quiere alabar, saltan a su memoria miles de poemas de este género, si quiere escoger una rima concreta se encuentra cogido por los moldes o modelos anteriores y cada vez más siente el poeta la estrechez del espacio creativo y a la fuerza cae en el tópico. Cuando alguna vez logra librarse es si el tema, la rima o el metro no son del mismo género del poema anterior aunque saltarán a la vista del crítico modelos y frases

\footnotetext{
${ }^{9}$ Emilio García Gómez, ob. cit., p. 12.

${ }^{10}$ Ibid., p. 82.
} 
hechas e imágenes adquiridas que dejan sentir la caída del poeta en el bando conservador y tópico. Los ejemplos de esto son innumerables; basta repasar cualquier poema panegírico o satírico para sentar entre líneas el rastro de las grandes figuras que fueran símbolo que caracteriza este campo: en las sátiras sobresale al-Ḥutay'a, Ŷarīr y su compañero al-Farazdaq, Buššār, etc., y en el panegírico y la descripción de batallas no puede olvidarse el fervor de al-Mutanabbī, y en la poesía de autoalabanza jamás queda lejana la figura de Abū Firās, sino que se siente entre los de al-Mu'tamid, rey de Sevilla. Si busca el poeta el género floral, no tiene más remedio que acudir a al-Sanawbarī, y si aspira al amor espiritual no deja de repasar la poesía 'Uḍrī. Por eso la poesía árabe se caracteriza por su temperamento conservador y aburrido, pese a haber sufrido algunas convulsiones producidas por las Muwaššahat y los zéjeles, que por su carácter extraño al común de la poesía árabe fueron rápidamente desechados y no llegaron más allá del siglo XIV. Ibn al-Jațịb nos informa: "Las Muwaššahat fueron un invento propio de los andalusíes que hoy día han desaparecido"11. Es decir por su ilegitimidad fue rechazada la Muwaššaha, pues no cumplía con todo lo que hemos explicado, además la larga trayectoria de la poesía árabe a mi modo de ver se queda sabiamente difundida por la visión inteligente de Don Emilio García Gómez que siempre acierta cuando dice: "Entre nosotros la perspectiva general histórica la poseen algunos artistas de excepción, y, por vía profesional, los historiadores y los eruditos, mientras los artistas normales representan su papel ante el telón corto de su propia y limitada crítica. Entre los árabes, en cambio, no hay telones cortos, foros ni forillos: todos los artistas representan en un escenario nudo, cada día más amplio, y donde, por tanto, cada día se empeque-

${ }^{11}$ Ibn al-Jaṭīb, Ihāta fì ajbār Garnāṭa, edición de Muḥammad 'Abd 'Allāh 'Inān, El Cairo, 1978, vol, IV, p. 525. 
ñecen más las figuras. Nosotros medimos cada momento estético por su propio patrón, mientras los árabes lo mesuran por un patrón eterno" 12 .

12 Emilio García Gómez, "Un eclipse de la poesía en Sevilla", en $A l-$ Andalus, 1945, vol. X, p. 308. 


\section{Criterios de edición:}

Revista Argelina. Revista semestral de Estudios Argelinos es una publicación electrónica e impresa evaluada por pares con tres criterios de selección: 1) aceptación; 2) aceptación con cambios; 3) devolución. Se aceptan contribuciones en castellano, valenciano, árabe, francés e inglés.

Los originales se presentarán registrándose como usuario y subiendo el documento a la plataforma OJS de la página electrónica: $\underline{\text { http://argelina.ua.es }}$

El aparato crítico deberá ajustarse a las siguientes normas de edición:

-Texto en formato estándar a un espacio de interlineado.

-Fuente en Romanas (Times New Roman) a 12 puntos.

-Título del trabajo en mayúsculas a 16 puntos seguido en línea inferior por el nombre del autor en versalitas.

-Notas a pie de página a 10 puntos.

-Cita: Libro (Nombre, Titulo, Ciudad, Editorial, Año); Artículo (Nombre, "Título", en Revista, Año, vol. X, núm. X, pp. $\mathrm{XX})$.

-Sistema internacional para las citas y transcripciones del árabe. 


\section{معايير النشر :}

المجلة الجزائرية هي مجلّة علمية ومحكمة، مخصصة للدراسات المتعلقة بالجزائر، مقرّها بإِسبانيا، تطبع

$$
\text { أعدادها ورقيا وإلكترونيا كل ستة أشهر. }
$$

يستقبل المركز طلبات نشر الأبحاث والدراسات المنجزة وفق معايير الكتابة والنشر الخدّدة في متن هذه

- تخضع المواد المرسلة كلّها للتّقييم والقراءة الأكاديميّة.

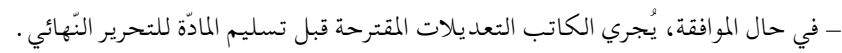

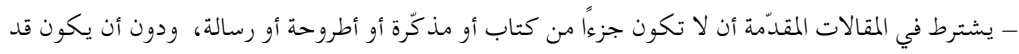
تمّ تقديمها سابقا لأي جهة علمية أخرى.

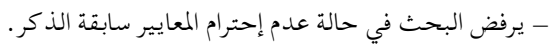

$$
\text { يمكن المساهمة باللغات التالية : العربيّة، الإسبانية، الفرنسية، الفلنسيانية والإنجليزيّة. }
$$

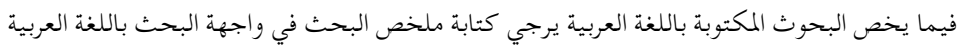

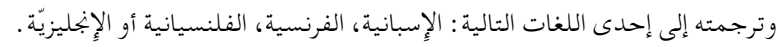

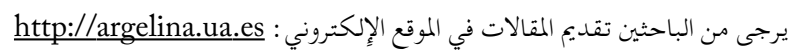

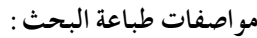

بهدف توحيد توثيق المصادر بشكل علميّ في كلّ أبحاث البجلة، يُرجى من الباحثين الكرام اعتماد أسلوب

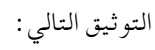

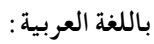

Traditional Arabic خط العناوين :بنط 16 ثقيل - خط المتن: بنط 16 عادي Traditional Arabic - خط الهوامش: حجم 12 عادي Traditional Arabic

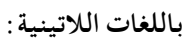
- تنسيق النص القياسي في مسافة سطر.

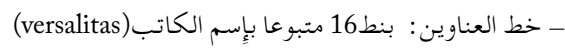
- خط المتن: بنط12 عادي(Times New Roman)

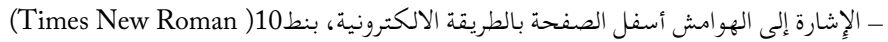

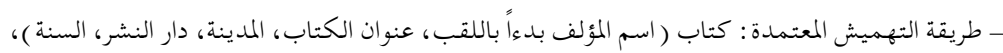

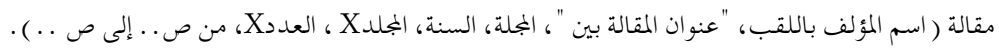

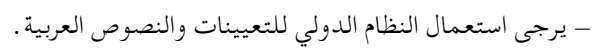

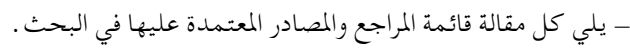




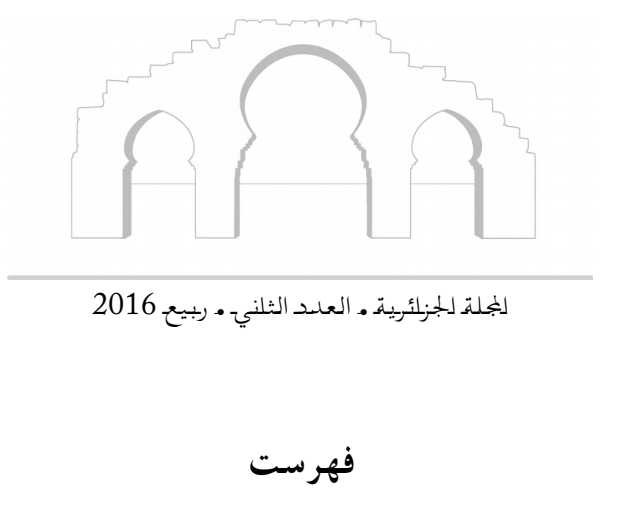

مقالات

أحمد بقار

بناء الصورة في شعر عبد الله حمادي ....................................... محمد الأمين شيخة

معالم نقدية وفكرية في ثنائية " البرزخ والسكين" للشاعر عبد الله حمادي ... 87

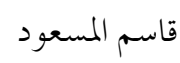

أفق التوقع في ديو ان "أنطق عن الهوى" لـ: عبد الله حمادي ..................... روفيا بوغنوط

أقانيم الكتابة : الفيض الصوفي في تشكيل العنونة في ديوان " أنطق عن الهـوى" لـ: 137 عبد الله حمادي ... 


$$
\text { العدد الثاني • ربيع } 2016
$$

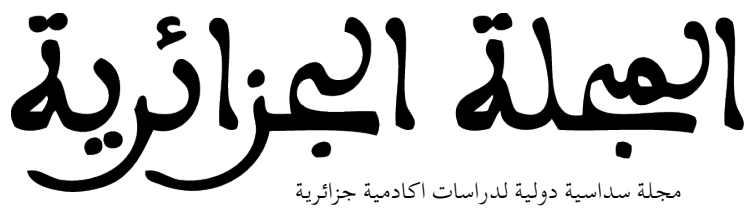




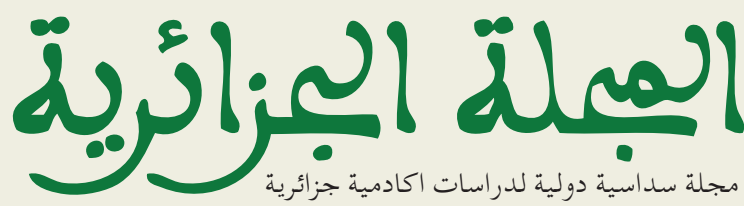

\section{ÍNDICE}

\section{Editorial}

Homenaje a Abdallah Hammadi

\section{Entrevista}

Entrevista con Abdallah Hammadi

\section{Artículos y notas}

IsAAC Donoso

Abdallah Hammadi: ética y estética neoandalusí.

Juan Martos Quesada

Abdallah Hammadi en España: poemas de juventud

IsAAc Donoso

Cuestiones epistemológicas de literatura argelina contemporánea

\section{Biblioteca}

Abdallah Hammadi

Converso con el olvido (Poemas)

Abdallah Hammadi

El conservadurismo en la poesía árabe

أقانيم الكتابة : الفيض الصوفي في تشكيل العنونة في ديوان "أنطق عن الهوى" لـ: عبد الله حمادي .. 137 